Prepared in cooperation with the U.S. Environmental Protection Agency

Hydrogeologic Framework, Water Levels, and Selected Contaminant Concentrations at Valmont TCE Superfund Site, Luzerne County, Pennsylvania, 2020
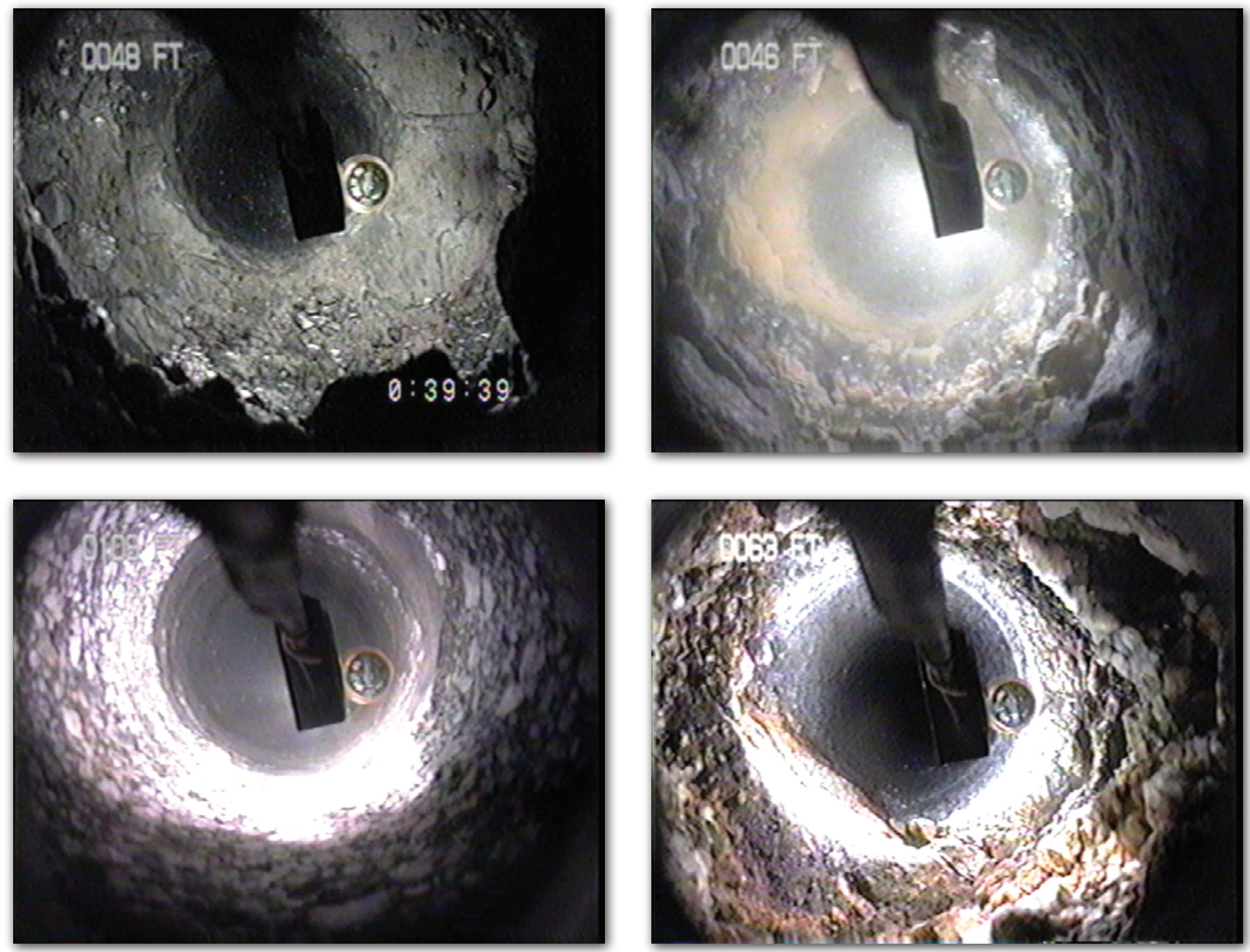

Open-File Report 2021-1093

Version 1.1, August 2022

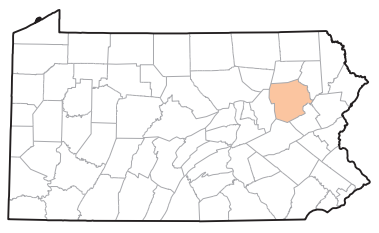

U.S. Department of the Interior

U.S. Geological Survey 
Cover. Still images from borehole video logs in monitoring wells for (clockwise from upper left) MW-12 at 48 feet below land surface (ft bls), MW-16 at $46 \mathrm{ft}$ bls, MW-15 at $63 \mathrm{ft}$ bls, and MW-12 at $109 \mathrm{ft}$ bls,Valmont TCE Superfund Site, 2002. Images collected by Philip H. Bird, U.S. Geological Survey, 


\section{Hydrogeologic Framework, Water Levels, and Selected Contaminant Concentrations at Valmont TCE Superfund Site, Luzerne County, Pennsylvania, 2020}

By Lisa A. Senior, Alex R. Fiore, and Philip H. Bird

Prepared in cooperation with the U.S. Environmental Protection Agency

Open-File Report 2021-1093

Version 1.1, August 2022

U.S. Department of the Interior

U.S. Geological Survey 


\section{U.S. Geological Survey, Reston, Virginia: 2021}

\section{Revised: August 2022 (ver. 1.1)}

For more information on the USGS - the Federal source for science about the Earth, its natural and living resources, natural hazards, and the environment—visit https://www.usgs.gov or call 1-888-ASK-USGS.

For an overview of USGS information products, including maps, imagery, and publications, visit https://store.usgs.gov/.

Any use of trade, firm, or product names is for descriptive purposes only and does not imply endorsement by the U.S. Government.

Although this information product, for the most part, is in the public domain, it also may contain copyrighted materials as noted in the text. Permission to reproduce copyrighted items must be secured from the copyright owner.

Suggested citation:

Senior, L.A., Fiore, A.R., and Bird, P.H., 2021, Hydrogeologic framework, water levels, and selected contaminant concentrations at Valmont TCE Superfund Site, Luzerne County, Pennsylvania, 2020 (ver. 1.1, August 2022): U.S. Geological Survey Open-File Report 2021-1093, 80 p., https://doi.org/10.3133/ofr20211093.

ISSN 2331-1258 (online) 


\section{Acknowledgments}

The assistance of Brad White and others of the U.S. Environmental Protection Agency (EPA), Region 3, in providing reports and data is gratefully acknowledged. Data provided by the EPA included geophysical logs, results of chemical analyses, and water levels. Geophysical logs used to help develop the hydrogeologic framework for this study were collected in wells at and near the Valmont TCE Superfund Site by Tetra Tech NUS, Inc. subcontractors for EPA during 2009-14. Additional information about wells in the area was provided by the Pennsylvania Department of Environmental Protection. Technical reviews by Randall Bayless and Mitchell McAdoo, U.S. Geological Survey, are appreciated. Randall Conger, U.S. Geological Survey, collected geophysical logs in wells at and near the Valmont TCE Site during 2002-03. 



\section{Contents}

Acknowledgments ……...................................................................................................................

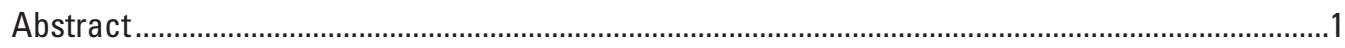

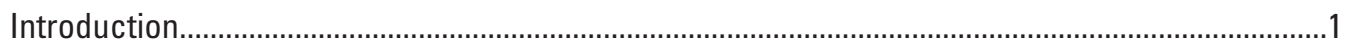

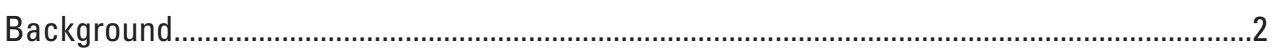

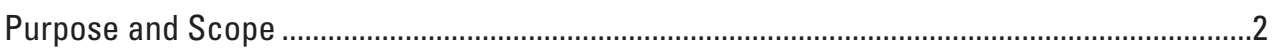

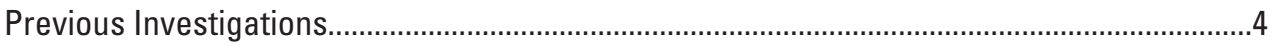

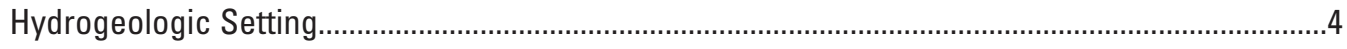

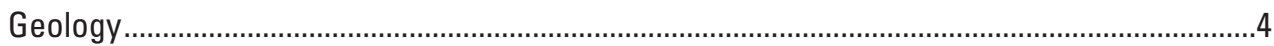

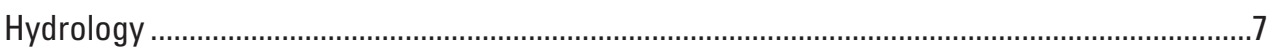

Hydrogeologic Framework, Water Levels, and Selected Contaminant Concentrations .................10

Geophysical Logs, Lithology, Structure, and Water-Bearing Zones .......................................10

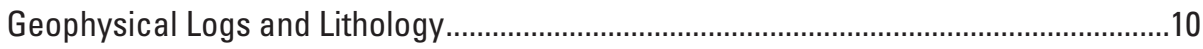

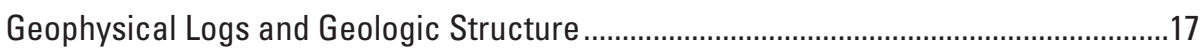

Geophysical Logs and Water-Bearing Zones .............................................................24

Correlation of Geophysical Logs, Water Levels, and Selected Contaminant

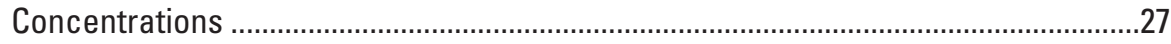

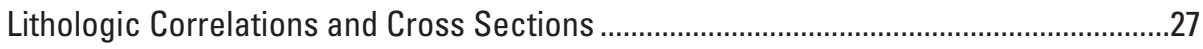

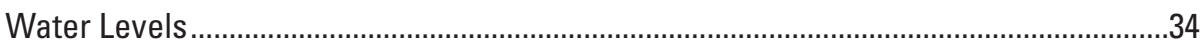

Selected Contaminants...............................................................................................37

Discussion of Hydrogeologic Framework, Water Levels, and Contaminant Distribution........45

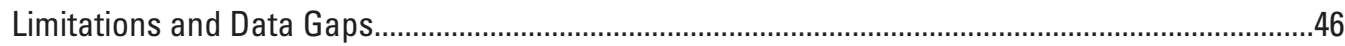

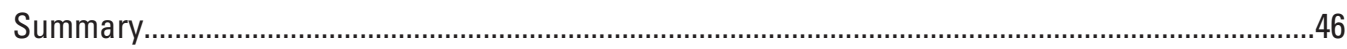

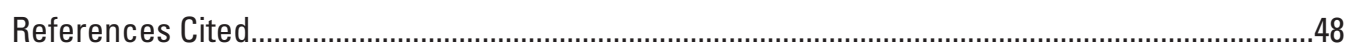

Appendix 1. Supplementary Geophysical Log Figures............................................................51

Appendix 2. Supplementary Hydrologic Data..............................................................................73

\section{Figures}

1. The Valmont TCE Superfund Site, Luzerne County, Pennsylvania, including topography and streams.

2. Physiographic provinces and sections, streams, and location of Valmont

TCE Superfund Site, Luzerne County, Pennsylvania and selected nearby U.S.

Geological Survey long-term data collection sites at streamgage 01538000 on Wapwallopen Creek and observation well CB-104.

3. Mapped geologic units and structure on the Conyngham quadrangle in the vicinity of Valmont TCE Superfund Site, Luzerne County.

4. Synclinal structure, faults, and contact between the Pottsville Formation and underlying Mauch Chunk Formation on Spring Mountain, Schuylkill County, Pennsylvania ....

5. Graphs showing northwest-to-southeast and southwest-to-northeast trending topographic profiles of land-surface altitudes at and near the Valmont TCE Superfund Site 
6. Graphs showing long-term daily median and 2015-20 daily mean water levels in U.S. Geological Survey observation well CB-104 in Carbon County, Pennsylvania, and computed monthly average 2015-20 base flow at USGS streamgage 01538000 Wapwallopen Creek near Wapwallopen, PA

7. Location of wells with geophysical logs used for correlation and other wells at and near the Valmont TCE Superfund Site, Luzerne County, Pennsylvania.

8. Geophysical logs with notes about lithology from geologist logs and interpreted water-bearing zones for open borehole MW-12D and intervals selected for screening when the well was constructed as well MW-12D, Valmont TCE Superfund Site, Luzerne County, Pennsylvania .

9. Still images of video logs showing different lithologies including light medium-grained sandstone at about 50 feet below land surface in borehole MW-19D, dark fine-grained sandstone at about $67 \mathrm{ft}$ bls in borehole MW-19D, coarse conglomerate at about $115 \mathrm{ft}$ bls in borehole MW-19D, shale at about $54 \mathrm{ft} \mathrm{bls} \mathrm{in} \mathrm{borehole} \mathrm{MW-12D,} \mathrm{coal} \mathrm{seen} \mathrm{as} \mathrm{shiny} \mathrm{layer} \mathrm{at} \mathrm{about} 68 \mathrm{ft}$ bls in borehole MW-12D, and possible bony coal at about $60 \mathrm{ft}$ bls in borehole MW-11D, Valmont TCE Superfund Site, Luzerne County, Pennsylvania

10. Natural gamma, density, porosity, and optical and acoustic televiewer logs for open borehole E-3, annotated with comments about lithology from review of logs, Valmont TCE Superfund Site, Luzerne County, Pennsylvania

11. Natural gamma and caliper logs for open boreholes E-3 and E-4, annotated with comments about lithology from review of optical televiewer logs, Valmont TCE Superfund Site, Luzerne County, Pennsylvania

12. Still images from borehole video log showing changes in bedding orientation and possibly structural features in open borehole MW-15D, Valmont TCE Superfund Site, Luzerne County, Pennsylvania ..

13. Still images of video logs showing changes in bedding orientation and possibly structural features including eastward dipping beds at about 64 feet below land surface in borehole MW-11D, nearly horizontal fractures in dipping sandstone at about $78 \mathrm{ft}$ bls in borehole MW-11D, an intensely fractured zone at about $56 \mathrm{ft}$ bls in borehole MW-21D, southwest dipping conglomerate beds at about $35 \mathrm{ft}$ bls in borehole MW-14D, a fractured zone at about $38 \mathrm{ft}$ bls in borehole MW-14D, and a southwest-dipping bedding contact between sandstone and shale at about $61 \mathrm{ft}$ bls in borehole MW-14D, Valmont TCE Superfund Site, Luzerne County, Pennsylvania

14. Still images of video logs showing water-bearing openings including $A$, at a contact between conglomerate and underlying shale at about 48 feet below land surface in borehole MW-12D, at a lithologic contact at about $91.5 \mathrm{ft}$ bls in borehole MW-12D, at a lithologic contact at about $67 \mathrm{ft}$ bls in borehole $M W-15 D$, in a low-angle opening at a contact between conglomerate and underlying shale at about $103 \mathrm{ft}$ bls in borehole MW-11D, in shale layers at about $57 \mathrm{ft}$ bls in borehole MW-22D, and in a light-colored apparently mineralized zone within reddish Mauch Chunk Formation sandstone at about $295 \mathrm{ft}$ bls in borehole MW-22D, Valmont TCE Superfund Site, Luzerne County, Pennsylvania 
15. Still images of video logs showing water-bearing openings including at lithologic contact at about 157 feet below land surface in borehole MW-14D feet, a rough broken opening above the contact near $42 \mathrm{ft}$ bls in well GW-26, at a lithologic contact below the coal layer at about $47 \mathrm{ft}$ bls in borehole MW-16D, at a lithologic contact with possible thin bony coal seams near $27 \mathrm{ft} \mathrm{bls} \mathrm{in}$ borehole MW-6, at a lithologic contact below the coal layer at about $81 \mathrm{ft} \mathrm{bls}$ in borehole MW-13D, and at a large opening near $34 \mathrm{ft}$ bls above the lithologic contact in borehole MW-17D, Valmont TCE Superfund Site, Luzerne County, Pennsylvania .....

16. Selected mapped geologic structures and location of cross sections developed by the U.S. Geological Survey using geophysical log correlation at and near the Valmont TCE Superfund Site, Luzerne County, Pennsylvania

17. Water-level altitudes measured on March 4, 2020, and contoured water-level altitudes for wells with depths to bottom of screened or open interval less than 60 feet below land surface, Valmont TCE Superfund Site, Luzerne County, Pennsylvania ...

18. Water-level altitudes measured on March 4, 2020, and contoured water-level altitudes for wells with depths to bottom of screened or open interval greater than or equal to 60 feet below land surface, Valmont TCE Superfund Site, Luzerne County, Pennsylvania.

19. Trichloroethene concentrations in February-March 2020 groundwater samples and contoured TCE groundwater concentrations for wells with depths to bottom of open interval less than 60 feet below land surface, Valmont TCE Superfund Site, Luzerne County, Pennsylvania

20. Trichloroethene concentrations in February-March 2020 groundwater samples and contoured TCE groundwater concentrations for wells with depths to bottom of open interval greater than or equal to 60 feet below land surface, Valmont TCE Superfund Site, Luzerne County, Pennsylvania

21. Combined perfluorooctanoic acid and perfluorooctanesulfonic acid concentrations in 2016, 2018, and February-March 2020 groundwater samples and contoured combined PFOA and PFOS groundwater concentrations in wells with depths to bottom of open interval less than 60 feet, Valmont TCE Superfund Site, Luzerne County, Pennsylvania.

22. Combined perfluorooctanoic acid and perfluorooctanesulfonic acid concentrations in 2016, 2018, and February-March 2020 groundwater samples and contoured combined PFOA and PFOS (PFAS) groundwater concentrations for wells with depths to bottom of open interval greater than or equal to 60 feet (ft) below land surface, Valmont TCE Superfund Site, Luzerne County, Pennsylvania . 


\section{Tables}

1. Local well names assigned by the U.S. Environmental Protection Agency and U.S. Geological Survey; USGS station numbers; source, date, depth, section line for display; and type of geophysical logs in open-borehole wells used for correlation at and near the Valmont TCE Superfund Site, Luzerne County, Pennsylvania

2. Characteristics of open-borehole wells with geophysical logs used for correlation and of other wells without logs at and near the Valmont TCE Superfund Site, Luzerne County, Pennsylvania.

3. Water levels measured on March 4, 2020, in 76 wells; the results of laboratory analysis for trichloroethene, perfluorooctanoic acid, and perfluorooctanesulfonic acid in groundwater samples collected from February 16 to March 3, 2020, in 75 wells; and characteristics of wells with water-level and sample data at Valmont TCE Superfund Site, Luzerne County,

Pennsylvania

4. Maximum concentrations reported for volatile organic compounds detected in analyses of groundwater samples collected from 75 wells at Valmont TCE Superfund Site, Luzerne County, Pennsylvania, February 16 to March 3, 2020

5. Maximum concentrations reported for per- and polyfluoroalkyl substances (PFAS) detected in analyses of groundwater samples collected from 51 wells from February 16 to March 3, 2020, at Valmont TCE Site, Superfund Luzerne County, Pennsylvania

\section{List of Plates}

Plate 1 Section A-A' with geophysical log correlations, Valmont TCE Superfund Site, Luzerne County, Pennsylvania.

Plate 2 Section $A_{d}-A_{d}$ ' detail with geophysical log correlations, Valmont TCE Superfund Site, Luzerne County, Pennsylvania.

Plate 3 Section B-B' with geophysical log correlations, Valmont TCE Superfund Site, Luzerne County, Pennsylvania.

Plate 4 Section $B_{d}-B_{d}{ }^{\prime}$ detail with geophysical log correlations, Valmont TCE Superfund Site, Luzerne County, Pennsylvania.

Plate 5 Section C-C' with geophysical log correlations, Valmont TCE Superfund Site, Luzerne County, Pennsylvania.

Plate 6 Section D-D' with geophysical log correlations, generalized potentiometric surfaces, and trichloroethene concentrations, Valmont TCE Superfund Site, Luzerne County, Pennsylvania, February-March 2020.

Plate 7 Section E-E' with geophysical log correlations, Valmont TCE Superfund Site, Luzerne County, Pennsylvania.

Plate 8 Section F-F' with geophysical log correlations, Valmont TCE Superfund Site, Luzerne County, Pennsylvania.

Plate 9 Section G-G' with geophysical log correlations $(A)$ and generalized potentiometric surfaces and trichloroethene concentrations $(B)$, Valmont TCE Superfund Site, Luzerne County, Pennsylvania, February-March 2020.

Plate 10 Section $\mathrm{H}-\mathrm{H}^{\prime}$ with geophysical log correlations and trichloroethene concentrations, Valmont TCE Superfund Site, Luzerne County, Pennsylvania. 
Plate 11 Section A-A' with generalized potentiometric surfaces and trichloroethene concentrations, Valmont TCE Superfund Site, Luzerne County, Pennsylvania, February-March 2020.

Plate 12 Section $A_{d}-A_{d}$ ' detail with generalized potentiometric surfaces and trichloroethene concentrations, Valmont TCE Superfund Site, Luzerne County, Pennsylvania, February-March 2020.

Plate 13 Section B-B' with generalized potentiometric surfaces and trichloroethene concentrations, Valmont TCE Superfund Site, Luzerne County, Pennsylvania, February-March 2020.

Plate 14 Section $B_{d}-B_{d}$ ' detail with generalized potentiometric surfaces and trichloroethene concentrations, Valmont TCE Superfund Site, Luzerne County, Pennsylvania, February-March 2020.

Plate 15 Section $\mathrm{C}-\mathrm{C}^{\prime}$ with generalized potentiometric surfaces and trichloroethene concentrations, Valmont TCE Superfund Site, Luzerne County, Pennsylvania, February-March 2020.

Plate 16 Section E-E' with generalized potentiometric surfaces and trichloroethene concentrations, Valmont TCE Superfund Site, Luzerne County, Pennsylvania, February-March 2020.

Plate 17 Section F-F' with generalized potentiometric surfaces and trichloroethene concentrations, Valmont TCE Superfund Site, Luzerne County, Pennsylvania, February-March 2020. 


\section{Conversion Factors}

U.S. customary units to International System of Units

\begin{tabular}{|c|c|c|}
\hline Multiply & By & To obtain \\
\hline \multicolumn{3}{|c|}{ Length } \\
\hline inch (in.) & 2.54 & centimeter $(\mathrm{cm})$ \\
\hline inch (in.) & 25.4 & millimeter $(\mathrm{mm})$ \\
\hline foot $(\mathrm{ft})$ & 0.3048 & meter $(\mathrm{m})$ \\
\hline mile (mi) & 1.609 & kilometer $(\mathrm{km})$ \\
\hline \multicolumn{3}{|c|}{ Area } \\
\hline acre & 0.4047 & hectare (ha) \\
\hline acre & 0.004047 & square kilometer $\left(\mathrm{km}^{2}\right)$ \\
\hline square mile $\left(\mathrm{mi}^{2}\right)$ & 259.0 & hectare (ha) \\
\hline square mile $\left(\mathrm{mi}^{2}\right)$ & 2.590 & square kilometer $\left(\mathrm{km}^{2}\right)$ \\
\hline \multicolumn{3}{|c|}{ Volume } \\
\hline gallon (gal) & 3.785 & liter $(\mathrm{L})$ \\
\hline gallon (gal) & 0.003785 & cubic meter $\left(\mathrm{m}^{3}\right)$ \\
\hline cubic foot $\left(\mathrm{ft}^{3}\right)$ & 0.02832 & cubic meter $\left(\mathrm{m}^{3}\right)$ \\
\hline \multicolumn{3}{|c|}{ Flow rate } \\
\hline cubic foot per second $\left(\mathrm{ft}^{3} / \mathrm{s}\right)$ & 0.02832 & cubic meter per second $\left(\mathrm{m}^{3} / \mathrm{s}\right)$ \\
\hline gallon per minute (gal/min) & 0.06309 & liter per second $(\mathrm{L} / \mathrm{s})$ \\
\hline inch per year (in/yr) & 25.4 & millimeter per year $(\mathrm{mm} / \mathrm{yr})$ \\
\hline \multicolumn{3}{|c|}{ Density } \\
\hline pound per cubic foot $\left(\mathrm{lb} / \mathrm{ft}^{3}\right)$ & 0.01602 & gram per cubic centimeter $\left(\mathrm{g} / \mathrm{cm}^{3}\right)$ \\
\hline \multicolumn{3}{|c|}{ Specific capacity } \\
\hline gallon per minute per foot ([gal/min $] / \mathrm{ft})$ & 0.2070 & liter per second per meter $([\mathrm{L} / \mathrm{s}] / \mathrm{m})$ \\
\hline \multicolumn{3}{|c|}{ Hydraulic conductivity } \\
\hline foot per day (ft/d) & 0.3048 & meter per day $(\mathrm{m} / \mathrm{d})$ \\
\hline \multicolumn{3}{|c|}{ Hydraulic gradient } \\
\hline foot per mile (ft/mi) & 0.1894 & meter per kilometer $(\mathrm{m} / \mathrm{km})$ \\
\hline \multicolumn{3}{|c|}{ Transmissivity } \\
\hline foot squared per day $\left(\mathrm{ft}^{2} / \mathrm{d}\right)$ & 0.09290 & meter squared per day $\left(\mathrm{m}^{2} / \mathrm{d}\right)$ \\
\hline
\end{tabular}

International System of Units to U.S. customary units

\begin{tabular}{|c|c|c|}
\hline Multiply & By & To obtain \\
\hline \multicolumn{3}{|c|}{ Length } \\
\hline centimeter $(\mathrm{cm})$ & 0.3937 & inch (in.) \\
\hline millimeter (mm) & 0.03937 & inch (in.) \\
\hline meter (m) & 3.281 & foot $(\mathrm{ft})$ \\
\hline kilometer (km) & 0.6214 & mile (mi) \\
\hline \multicolumn{3}{|c|}{ Area } \\
\hline square meter $\left(\mathrm{m}^{2}\right)$ & 10.76 & square foot $\left(\mathrm{ft}^{2}\right)$ \\
\hline hectare (ha) & 0.003861 & square mile $\left(\mathrm{mi}^{2}\right)$ \\
\hline
\end{tabular}




\begin{tabular}{|c|c|c|}
\hline Multiply & By & To obtain \\
\hline \multicolumn{3}{|c|}{ Volume } \\
\hline liter $(\mathrm{L})$ & 0.2642 & gallon (gal) \\
\hline cubic meter $\left(\mathrm{m}^{3}\right)$ & 264.2 & gallon (gal) \\
\hline \multicolumn{3}{|c|}{ Flow rate } \\
\hline cubic meter per second $\left(\mathrm{m}^{3} / \mathrm{s}\right)$ & 35.31 & cubic foot per second $\left(\mathrm{ft}^{3} / \mathrm{s}\right)$ \\
\hline \multicolumn{3}{|c|}{ Mass } \\
\hline $\operatorname{gram}(\mathrm{g})$ & 0.03527 & ounce, avoirdupois (oz) \\
\hline \multicolumn{3}{|c|}{ Density } \\
\hline gram per cubic centimeter $\left(\mathrm{g} / \mathrm{cm}^{3}\right)$ & 62.4220 & pound per cubic foot $\left(\mathrm{lb} / \mathrm{ft}^{3}\right)$ \\
\hline \multicolumn{3}{|c|}{ Specific capacity } \\
\hline liter per second per meter $([\mathrm{L} / \mathrm{s}] / \mathrm{m})$ & 4.831 & gallon per minute per foot $([\mathrm{gal} / \mathrm{min}] / \mathrm{ft})$ \\
\hline \multicolumn{3}{|c|}{ Hydraulic conductivity } \\
\hline meter per day $(\mathrm{m} / \mathrm{d})$ & 3.281 & foot per day (ft/d) \\
\hline \multicolumn{3}{|c|}{ Hydraulic gradient } \\
\hline meter per kilometer $(\mathrm{m} / \mathrm{km})$ & 5.27983 & foot per mile (ft/mi) \\
\hline \multicolumn{3}{|c|}{ Transmissivity } \\
\hline meter squared per day $\left(\mathrm{m}^{2} / \mathrm{d}\right)$ & 10.76 & foot squared per day $\left(\mathrm{ft}^{2} / \mathrm{d}\right)$ \\
\hline
\end{tabular}

Temperature in degrees Celsius $\left({ }^{\circ} \mathrm{C}\right)$ may be converted to degrees Fahrenheit $\left({ }^{\circ} \mathrm{F}\right)$ as follows: ${ }^{\circ} \mathrm{F}$ $=\left(1.8 \times{ }^{\circ} \mathrm{C}\right)+32$.

Temperature in degrees Fahrenheit $\left({ }^{\circ} \mathrm{F}\right)$ may be converted to degrees Celsius $\left({ }^{\circ} \mathrm{C}\right)$ as follows: ${ }^{\circ} \mathrm{C}$ $=\left({ }^{\circ} \mathrm{F}-32\right) / 1.8$.

\section{Datum}

Vertical coordinate information is referenced to the North American Vertical Datum of 1988 (NAVD 88)]

Horizontal coordinate information is referenced to the North American Datum of 1983 (NAD 83)]. Altitude, as used in this report, refers to distance above the vertical datum.

\section{Supplemental Information}

Specific conductance is given in microsiemens per centimeter at 25 degrees Celsius $(\mu \mathrm{S} / \mathrm{cm}$ at $\left.25^{\circ} \mathrm{C}\right)$.

Concentrations of chemical constituents in water are given in either milligrams per liter (mg/L), micrograms per liter $(\mu \mathrm{g} / \mathrm{L})$, or nanograms per liter $(\mathrm{ng} / \mathrm{L})$.

Geophysical log data are reported in the following units: natural gamma activity in counts per second (cps), single-point resistance in ohms; apparent formation resistivity in ohm-meters (ohm-m); fluid temperature in degrees Celsius $\left({ }^{\circ} \mathrm{C}\right)$; fluid resistivity in ohms-meters (ohm-m); caliper, in inches (in.); flow rates, in gallons per minute (gal/min); and density, in grams per cubic centimeter $\left(\mathrm{g} / \mathrm{cm}^{3}\right)$. 


\section{Abbreviations}

$\begin{array}{ll}\text { ATV } & \text { acoustic televiewer } \\ \text { bls } & \text { below land surface } \\ \text { COC } & \text { contaminants of concern } \\ \text { DCE } & \text { cis-1,2-dichloroethylene } \\ \text { DNAPL } & \text { Dense Nonaqueous Phase Liquid } \\ \text { EPA } & \text { U.S. Environmental Protection Agency } \\ \text { HA } & \text { health advisory } \\ \text { ISCO } & \text { in situ chemical oxidation } \\ \text { MCL } & \text { maximum contaminant level } \\ \text { NAD 83 } & \text { North American Datum of 1983 } \\ \text { NAVD 88 } & \text { North American Vertical Datum of 1988 } \\ \text { NGVD 29 } & \text { National Geodetic Vertical Datum of 1929 } \\ \text { OTV } & \text { optical televiewer } \\ \text { PFAS } & \text { per- and polyfluoroalkyl substances } \\ \text { PFBS } & \text { perfluorobutanesulfonic acid } \\ \text { PFHpA } & \text { perfluoroheptanoic acid } \\ \text { PFHxA } & \text { perfluorohexanoic acid } \\ \text { PFHxS } & \text { perfluorohexanesulfonic acid } \\ \text { PFNA } & \text { perfluorononanoic acid } \\ \text { PFOA } & \text { Perfluorooctanoic acid } \\ \text { PFOS } & \text { Perfluorooctanesulfonic acid } \\ \text { PFUnA } & \text { perfluoroundecanoic acid } \\ \text { ppm } & \text { parts per million } \\ \text { ROD } & \text { record of decision } \\ \text { TCA } & \text { 1,1,1-trichloroethane } \\ \text { TCE } & \text { trichloroethene } \\ \text { USGS } & \text { U.S. Geological Survey } \\ \text { VC } & \text { vinyl chloride } \\ \text { VOC } & \text { volatile organic compound } \\ \text { PFi }\end{array}$




\title{
Hydrogeologic Framework, Water Levels, and Selected Contaminant Concentrations at Valmont TCE Superfund Site, Luzerne County, Pennsylvania, 2020
}

\author{
By Lisa A. Senior, Alex R. Fiore, and Philip H. Bird
}

\section{Abstract}

The Valmont TCE Superfund Site, Luzerne County, Pennsylvania is underlain by fractured and folded sandstones and shales of the Pottsville and Mauch Chunk Formations, which form a fractured-rock aquifer recharged locally by precipitation. Industrial activities at the former Chromatex Plant resulted in trichloroethene (TCE) contamination of groundwater at and near the facility, which was identified in 1987 and led to listing as a Superfund site by the U.S. Environmental Protection Agency (EPA) in 1989. To address the problem of TCE concentrations in nearby residential wells that exceed the maximum contaminant level (MCL) of 5 micrograms per liter $(\mu \mathrm{g} / \mathrm{L})$ for drinking water, alternate water supplies were provided. A 2015 review of initial characterization and subsequent remediation by the EPA identified the need for an updated understanding of the complex hydrogeology and the conceptual site model. Additional contaminants present in groundwater at the site include some other volatile organic compounds (VOCs) and per- and polyfluoroalkyl substances (PFAS), predominantly consisting of perfluorooctanoic acid (PFOA) and perfluorooctanesulfonic acid (PFOS) measured in concentrations that exceeded the EPA Health Advisory (HA) level of 5 nanograms per liter (ng/L) for combined PFOA and PFOS.

In response to a request from the EPA in 2019, the U.S. Geological Survey (USGS) prepared cross sections and maps to provide more information about the hydrogeologic framework at and near the site and assist in improving the conceptual site model using water level and contaminant data collected by the EPA in 2020 . The cross sections present lithologic correlations from available geophysical logs collected in wells from 2002 to 2014; they show alternating intervals of relatively elevated and reduced natural gamma activity that correspond to changes in lithology, with waterbearing zones and well screens commonly located at lithologic contacts, sometimes near thin coal seams. Water-bearing zones commonly are associated with fractures at or near lithologic contacts but also may be associated with fractures at or near apparent faulting. Recent (March 2020) water-level data shown on cross sections and maps indicate large downward vertical gradients and apparent radial gradients laterally to the northeast, northwest, and southwest that generally following topography. Recent (February to March 2020) data for TCE groundwater concentration shown on cross sections and maps indicate the highest TCE concentrations (greater than $3,000 \mu \mathrm{g} / \mathrm{L}$ and as much as $75,000 \mu \mathrm{g} / \mathrm{L}$ ) and combined PFOA and PFOS concentrations (greater than $1,000 \mathrm{ng} / \mathrm{L}$ and up to at least 2,350 ng/L) are from shallow (less than 60 feet [ft] below land surface [bls]) and intermediate depth (60 to $100 \mathrm{ft}$ bls) wells near the center of the former Chromatex Plant. TCE and PFAS (as combined PFOA and PFOS) contamination is present in groundwater at greater depths, as much as $304 \mathrm{ft} \mathrm{bls,} \mathrm{as}$ evidenced by samples collected from one well (a reconstructed former production well) near the plant, that contained concentrations of about $240 \mu \mathrm{g} / \mathrm{L}$ and $508 \mathrm{ng} / \mathrm{L}$, respectively. The 2020 data also indicate that TCE and PFAS concentrations which exceed drinking-water MCL or HA levels are present in groundwater depths of less than $200 \mathrm{ft}$ in an area that extends predominantly in a northeast direction from the former Chromatex Plant, and is apparently influenced by hydraulic gradients, lithology, and geologic structure.

\section{Introduction}

The Valmont TCE Superfund Site (Site), in Valmont Industrial Park on Jaycee Drive near Deer Run Road in Hazle Township and West Hazleton Borough, Luzerne County, Pennsylvania (fig. 1), consists of known source areas of trichloroethene (TCE) contamination at a former upholstery manufacturing plant (the Plant) operated by Chromatex, Inc. (Chromatex) from 1978 to 2001 but, since 2001, is no longer used for manufacturing. The northern half of the building that housed the former Chromatex Plant is currently (2021) used as a warehouse and owned by Karchner Warehousing and Logistics Co., LLC. The Site also includes an area of groundwater contamination that extends from the Plant to the northeast in the residential area of Twin Oaks Road, Bent Pine Trail and Deer Run Road. The Site is underlain by the Pennsylvanian Pottsville and the Mississippian Mauch Chunk Formations, which consist of conglomerate, sandstone, 
siltstone, as well as some thin beds of coal (in the Pottsville Formation), and form fractured-rock aquifers that are the primary source of water supply in the area.

\section{Background}

The principal sources of groundwater contamination at Valmont TCE Superfund Site are from activities at an industrial property, which has had several manufacturing operations since the Plant building was constructed in 1963, including coffin manufacture by Wallace Metal Products, Inc. (1966-72) and knitted fabric manufacture by Nutmeg Corporation and Futura Fabric Corporation (1972-78) (U.S. Environmental Protection Agency, 2016a). In 1978, the property was leased to and later (1991) purchased by Chromatex, who applied fluorocarbon stain repellants that contained TCE and other volatile organic compounds (VOCs) to fabrics. Spills of these chemicals during Chromatex operations resulted in TCE and fluorocarbon contamination of groundwater at and near the Plant. The fluorocarbon stain repellents included per- and polyfluoroalkyl substances (PFAS), and sampling done by the U.S. Environmental Protection Agency (EPA) and its consultants has identified the presence of at least two PFAS compounds, perfluorooctanoic acid (PFOA) and perfluorooctanesulfonic acid (PFOS), in groundwater and near the Plant (U.S. Environmental Protection Agency, 2016a). The EPA commonly defines PFOS using the term perfluorooctane sulfonate (U.S. Environmental Protection Agency, 2017), which is the conjugate base of the acid. The Plant building is currently (2021) owned by Karchner Warehousing and Logistics Co., LLC., who uses the building to store various materials.

Groundwater contamination at the Site was discovered by the Pennsylvania Department of Environmental Resources in 1987; in 1989, the EPA completed an assessment of contamination at Valmont and the property was placed on the National Priority List in 2001 (U.S. Environmental Protection Agency, 2016a). A combined remediation investigation/feasibility study and several removal actions, including soil removal and soil vapor extraction, were done by the EPA during 2001-10 and a record of decision (ROD) was completed in January 2011 (U.S. Environmental Protection Agency, 2011), followed by EPA remedial design, remedial action, and long-term response action during 2011-14 (U.S. Environmental Protection Agency, 2016a). The first 5-year review was completed by the EPA in 2016 (U.S. Environmental Protection Agency, 2016a).

Contaminants of concern (COCs) identified in the ROD include TCE, cis-1,2-dichloroethylene (DCE), 1,1,1-trichloroethane (TCA), and vinyl chloride (VC) in groundwater and TCE, 1,1-DCE, and 1,1,1-TCA in indoor air (U.S. Environmental Protection Agency, 2011); TCE was considered the primary contaminant in groundwater at the Site, and TCE, cis-1,2-DCE, and 1,1,1-TCA all were present in groundwater in concentrations that exceeded the respective EPA maximum contaminant levels (MCLs) of 5, 70, and 200 micrograms per liter $(\mu \mathrm{g} / \mathrm{L})$ for drinking water. At the time of the ROD, the highest reported concentrations of these three compounds were $17,000 \mu \mathrm{g} / \mathrm{L}$ for TCE, $1,000 \mu \mathrm{g} / \mathrm{L}$ for cis-1,2-DCE , and $5,500 \mu \mathrm{g} / \mathrm{L}$ for $1,1,1-\mathrm{TCA}$ in groundwater samples from wells at and near the Plant (U.S. Environmental Protection Agency, 2011, 2018a). Remediation and removal actions in the residential area affected by groundwater or indoor air contamination include connecting all nearby residences with private wells to municipal water supply and, for properties with vapor intrusion issues, providing sub-slab depressurization systems. At the former Chromatex Plant property, the EPA removed contaminated soil in 2004, operated a soil vapor extraction system during 2007-09, and conducted a pilot study to evaluate the effectiveness of in situ chemical oxidation (ISCO) on remediating VOC contaminated groundwater in 2009. For the pilot study, a potassium permanganate slurry was injected under pressure at various depths into six 100 -ftdeep wells at the former Chromatex Plant property. The ROD selected ISCO as part of the groundwater remedy, and from 2011 through 2014, three rounds of injections were completed in as many as eight additional wells. However, evaluation of the extent of groundwater contamination in 2014 indicated that the groundwater remedy was not progressing towards cleanup goals in the expected period of time, and the EPA had an optimization review done in 2015 to assess ways to improve the remedy (U.S. Environmental Protection Agency, 2015, 2016a). The 2015 optimization review noted that high levels of contamination remain in an area beneath the Plant and identified the following issues to be addressed (U.S. Environmental Protection Agency, 2016a): critical data gaps; recommendations to improve characterization and the conceptual site model; and recommendations for remediation that included targeting efforts at source area contamination first in the next set of actions. Since 2016, when the EPA sampled new monitor wells drilled in response to the 2015 optimization review recommendations, additional contaminants in groundwater at the Site have been detected, including 1,4-dioxane (U.S. Environmental Protection Agency, 2016a). Monitoring for PFAS in groundwater was part of the ROD and has been done in at least some wells in the study area since 2010 (U.S. Environmental Protection Agency, 2016a). Laboratory capacity has been a limiting factor in the number of samples analyzed for PFAS (Brad White, U.S. Environmental Protection Agency, written commun., 2021). In 2016, the EPA established a Lifetime Health Advisory (HA) of 70 nanograms per liter (ng/L) for combined concentrations of PFOS and PFOA in drinking water (U.S. Environmental Protection Agency, 2016b).

\section{Purpose and Scope}

This report documents the correlation of geophysical logs commonly used to identify lithology—including natural gamma, single-point resistance, and neutron density logs - to help describe the hydrogeologic framework at and near the Valmont TCE Superfund Site. The geophysical logs were 


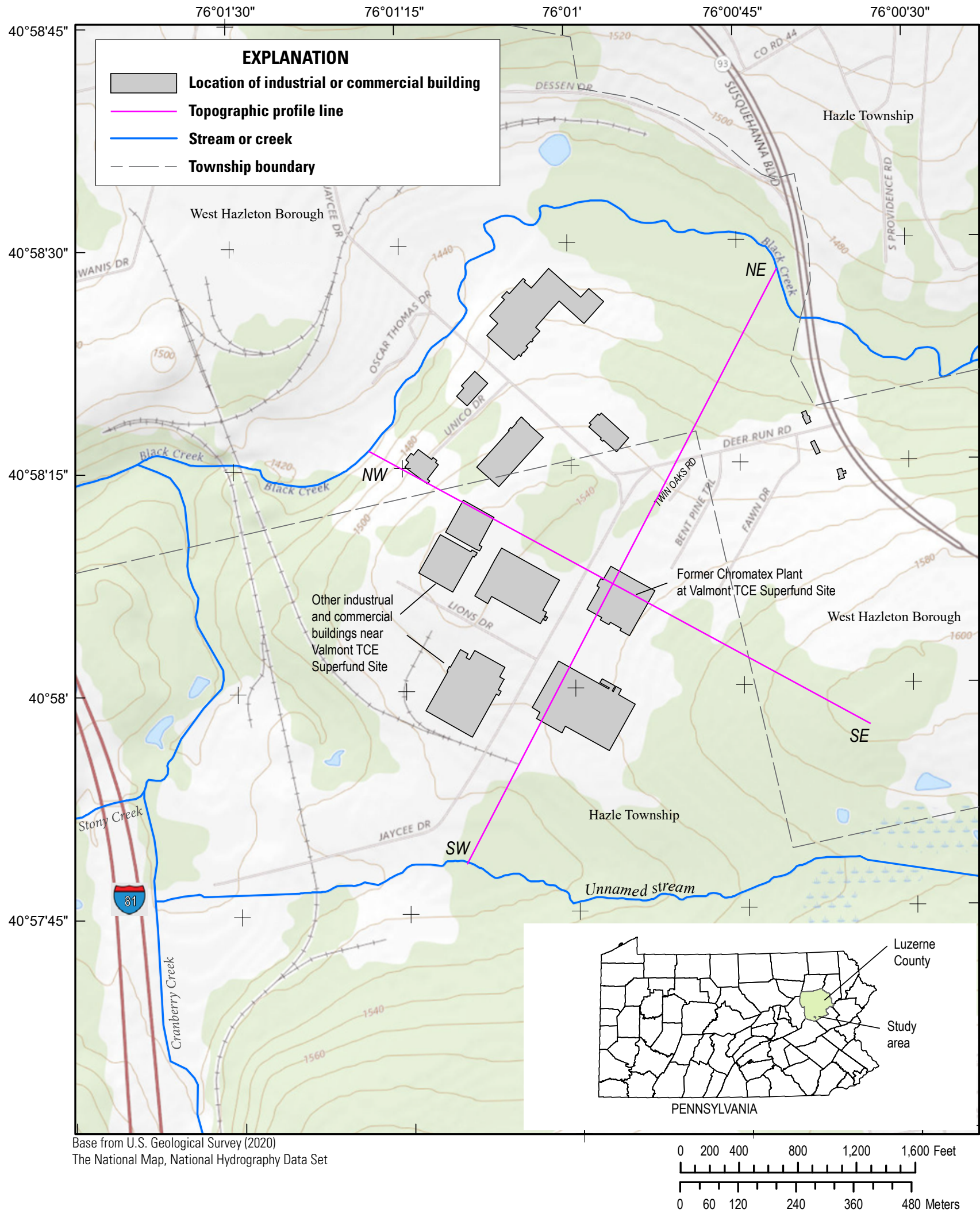

Figure 1. The Valmont TCE Superfund Site, Luzerne County, Pennsylvania, including topography and streams. Land surface altitudes for the topographic profile along southwest-northeast (SW-NE) and northwest-southeast (NW-SE) lines shown (in pink) are presented in figure 5 . 
collected by U.S. Geological Survey (USGS) and others working for the EPA from 2002 through 2014 in 44 wells ranging in depth from 76 to 400 feet (ft) below land surface (bls) at and near the Site. The lithologic correlations were determined using geophysical logs, and these correlations were used to develop cross sections that show lithology and depths of wells with geophysical logs. Water levels and concentrations of contaminants (TCE and PFAS) measured in wells during February-March 2020 are shown on plan-view maps and on cross sections, with interpreted contours for water levels on both maps and cross sections and interpreted contours for contaminants on maps only. The cross sections and maps are intended to provide updated information about the relation of the hydrogeologic framework to vertical and horizonal hydraulic gradients, which can be applied to infer potential generalized directions of groundwater flow and vertical and horizontal distribution of contaminants in groundwater. This updated information can be used by the EPA and other waterresource managers to assist in planning and evaluation of further remediation efforts and activities, including the identification of data gaps.

\section{Previous Investigations}

The hydrogeologic setting, local geology, and distribution of contamination in groundwater at various periods during 2002-16 at the Valmont TCE Superfund Site were described by the EPA in a remedial investigation (Tetra Tech NUS, Inc., 2004a,b) and subsequent studies related to remediation (Tetra Tech NUS, Inc., 2010, 2014, 2016). Additional characterization done after reconstruction of open boreholes in 2016 included aquifer testing (Tetra Tech NUS, Inc., 2017) and analysis of groundwater samples for PFAS concentrations (U.S. Environmental Protection Agency, 2018b).

\section{Hydrogeologic Setting}

The Valmont TCE Superfund Site is in the Anthracite Upland Section of the Valley and Ridge physiographic province (Ridge and Valley physiographic province in Pennsylvania Geological Survey nomenclature) (fig. 2), characterized as an upland with low, linear, rounded hills and having a geologic structure of many narrow folds with steep limbs, many faults, and a trellis drainage pattern (Sevon, 2000). The primary channels in the trellis drainage pattern are oriented approximately parallel to axes of regional folds, which generally trend east-northeast in southern Luzerne County near the Valmont TCE Superfund Site (fig. 2). Strip mining for coal has altered the land surface in some areas of the region. The study area is south of the extent of Pleistocene glaciation (Berg and others, 1980).

\section{Geology}

The Valmont TCE Superfund Site is underlain by the Mississippian Mauch Chunk Formation and Pennsylvanian Pottsville Formation, geologic units that generally consist of conglomerate, sandstone, siltstone, and some thin beds of anthracite (particularly in the Pottsville). In the vicinity of the Site, the Pottsville Formation occurs nearest to land surface and is underlain by the Mauch Chunk Formation. The coalbearing Pennsylvanian Llewellyn Formation, which consists of shale, siltstone, sandstone, and conglomerate, overlies the Pottsville Formation and crops out near, but not at, the Site (Berg and others, 1980). The depth to competent bedrock was reported to range from about 5 to $37 \mathrm{ft}$ bls in boring logs for wells drilled at and near Valmont TCE Superfund Site, with depths to competent bedrock most commonly ranging from about 8 to $12 \mathrm{ft}$ bls (Tetra Tech NUS, Inc., 2004b, 2010, 2011, 2014, 2016). Above the competent bedrock, soils and weathered bedrock, and in a few locations, artificial fill, are present.

Recent geologic mapping in the study area (Schasse and others, 2012) subdivides the Pottsville and Mauch Chunk Formations into members and shows the Sharp Mountain and Schuylkill Members, undivided, of the Pottsville Formation and the upper (unnamed) member of the Mauch Chunk Formation as present in the study area (fig. 3). The Sharp Mountain and Schuylkill Members, undivided, of the Pottsville Formation range from about 200 to $350 \mathrm{ft}$ in thickness and consist of predominantly medium to thick-bedded, tabular- and cross-bedded, gray quartz-rich conglomerate that is interbedded with thinner beds of medium to coarsegrained quartz-rich sandstones (Schasse and others, 2012). Thin to medium beds of dark gray to grayish-black micaceous sandstone, siltstone, shale, and claystone are present in the middle and upper parts of the undivided Sharp Mountain and Schuylkill Members and finer-grained beds in the middle part are associated with a thin shaly or bony coal seam (typically less than 3.5-ft thick) (Schasse and others, 2012). Edmunds and Gillmeister (1997) describe the occurrence of some fining upward sequences in the Pottsville Formation (predominantly composed of sandstones and conglomerates), with coal present at the top of the sequence. The upper (unnamed) member of the Mauch Chunk Formation has a thickness of about $650 \mathrm{ft}$ in the area and consists of claystone, siltstone, sandstone, and conglomerate arranged in fining upward cycles (Schasse and others, 2012).

The environment of deposition for the Pottsville Formation in eastern Pennsylvania is reported as an alluvial plain (Wood and others, 1969; Edmunds, 1997; Edmunds and Gillmeister, 1997). Bedding in such deposits may not be laterally continuous over extensive distances and can create hydrogeologic heterogeneity in the subsurface. Additionally, beds may vary in thickness at local scale and by lithology. Schasse and others (2012) state that bed thickness ranges from medium to very thick for predominant conglomerate and orthoquartzite 


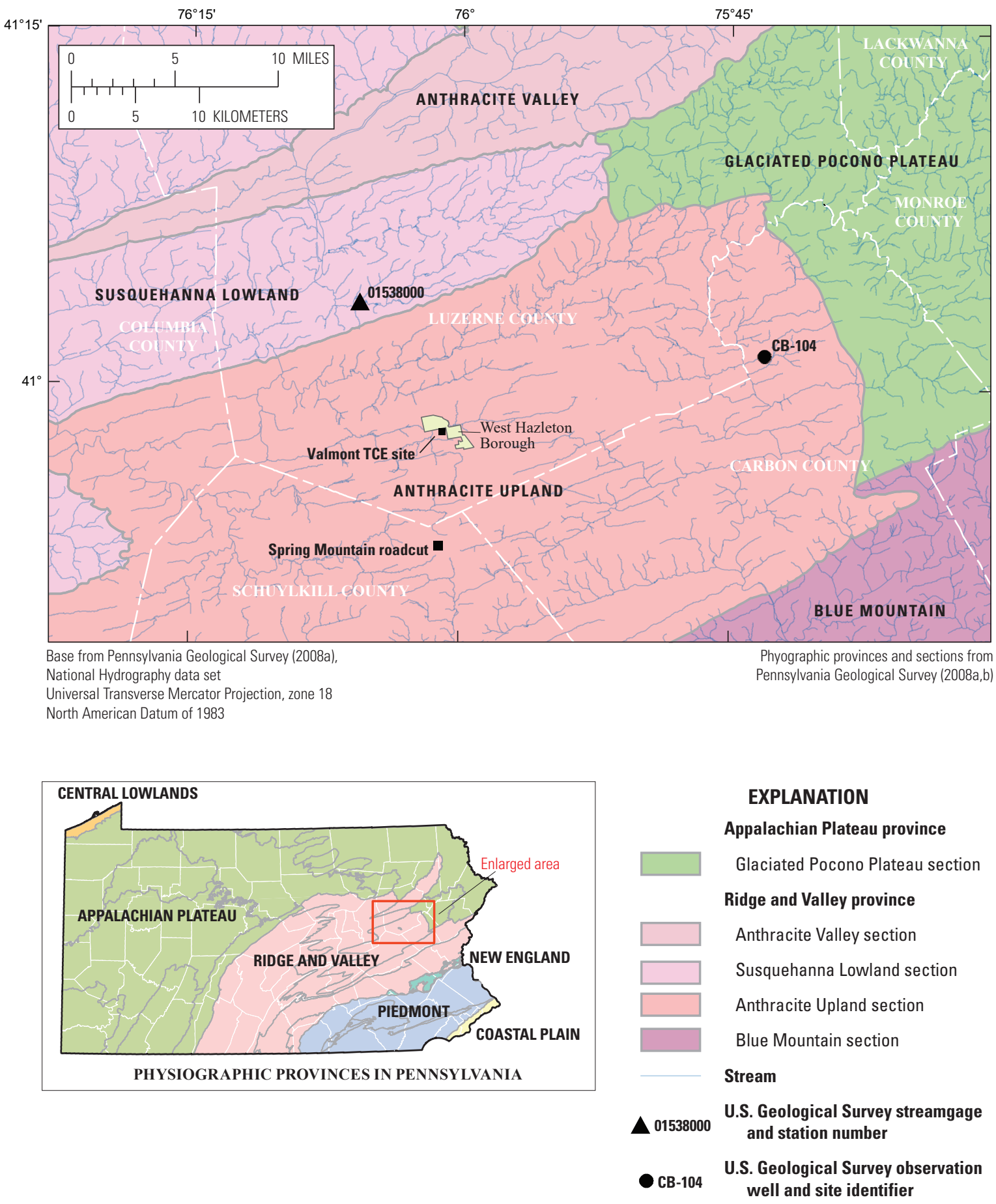

Figure 2. Physiographic provinces and sections, streams, and location of Valmont TCE Superfund Site, Luzerne County, Pennsylvania and selected nearby U.S. Geological Survey long-term data collection sites at streamgage 01538000 on Wapwallopen Creek and observation well CB-104. 


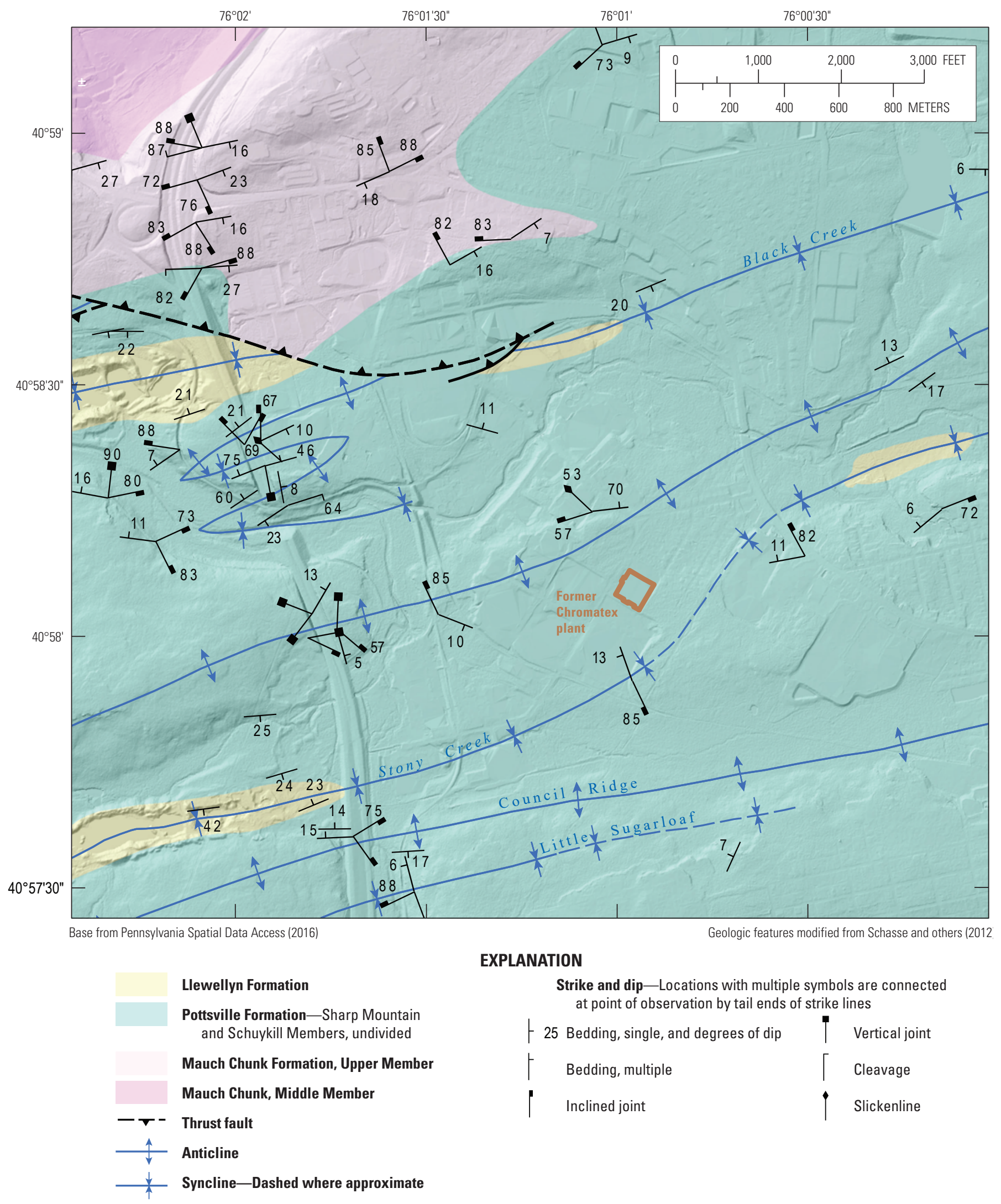

Figure 3. Mapped geologic units and structure on the Conyngham quadrangle in the vicinity of Valmont TCE Superfund Site, Luzerne County, from Schasse and others (2012). 
lithologies, and from thin to medium for finer grained lithologies (siltstone, clay shale, claystone, micaceous sandstone) in the Pottsville Formation.

The geologic structure in the study area has been mapped as a series of synclines and anticlines with northeast or eastnortheast trending axes, offset and affected by faulting (fig. 3; Schasse and others, 2012). The Valmont TCE Superfund Site lies between the axis of a northeast-trending syncline, tentatively mapped about $750 \mathrm{ft}$ southeast of the Plant, and the axis of an east-northeast trending anticline mapped about $1,000 \mathrm{ft}$ northwest of the Plant. Based on this regional structure, beds underlying the Plant might be anticipated to generally dip to the southeast. However, a mapped location of west-dipping bedding orientation about 1,000 ft south of the Plant (fig. 3; Schasse and others, 2012) suggests local-scale folds or faults may be present and result in locally complex structure. Also, the overall fold structures in the region may tilt or plunge (Lohman, 1937, p. 16), adding to structural complexity. A nearby example of synclinal structure with thrust faults and other faults in the Pottsville Formation and underlying Mauch Chunk Formation, as exposed in a road cut about 5.4 miles (mi) south of the Site (fig. 2), is described by Reese (2016) and shown in figure 4 .

\section{Hydrology}

The folded sedimentary geologic units which underlie Valmont TCE Superfund Site form fractured-rock aquifers that are recharged locally by precipitation that percolates through soils and weather bedrock (saprolite). Groundwater in this type of setting generally discharges locally to streams as base flow, such as in Black Creek in the vicinity of the Site (fig. 1). Groundwater flow in geologic units in the study area is primarily through fractures (secondary porosity). These fractures or openings may be parallel to, or at other angles to, bedding owing to the cross-bedded nature of the sandstone units and subsequent deformation. Fracture orientations that occur at angles to bedding may be related to geologic structure, especially near fold axes, and past stress fields from multiple complex deformation events (Burton and others, 2002; Evans and Sale, 2015).

Topographically, the Valmont TCE Superfund Site is on a saddle on an east-northeast trending ridge, such that the land surface slopes away to the northeast, northwest, and southwest (figs. 1 and 5). Commonly, in the noncarbonate fractured-rock setting in eastern Pennsylvania, the direction of groundwater flow generally follows topography, with discharge to streams

$\boldsymbol{A}$
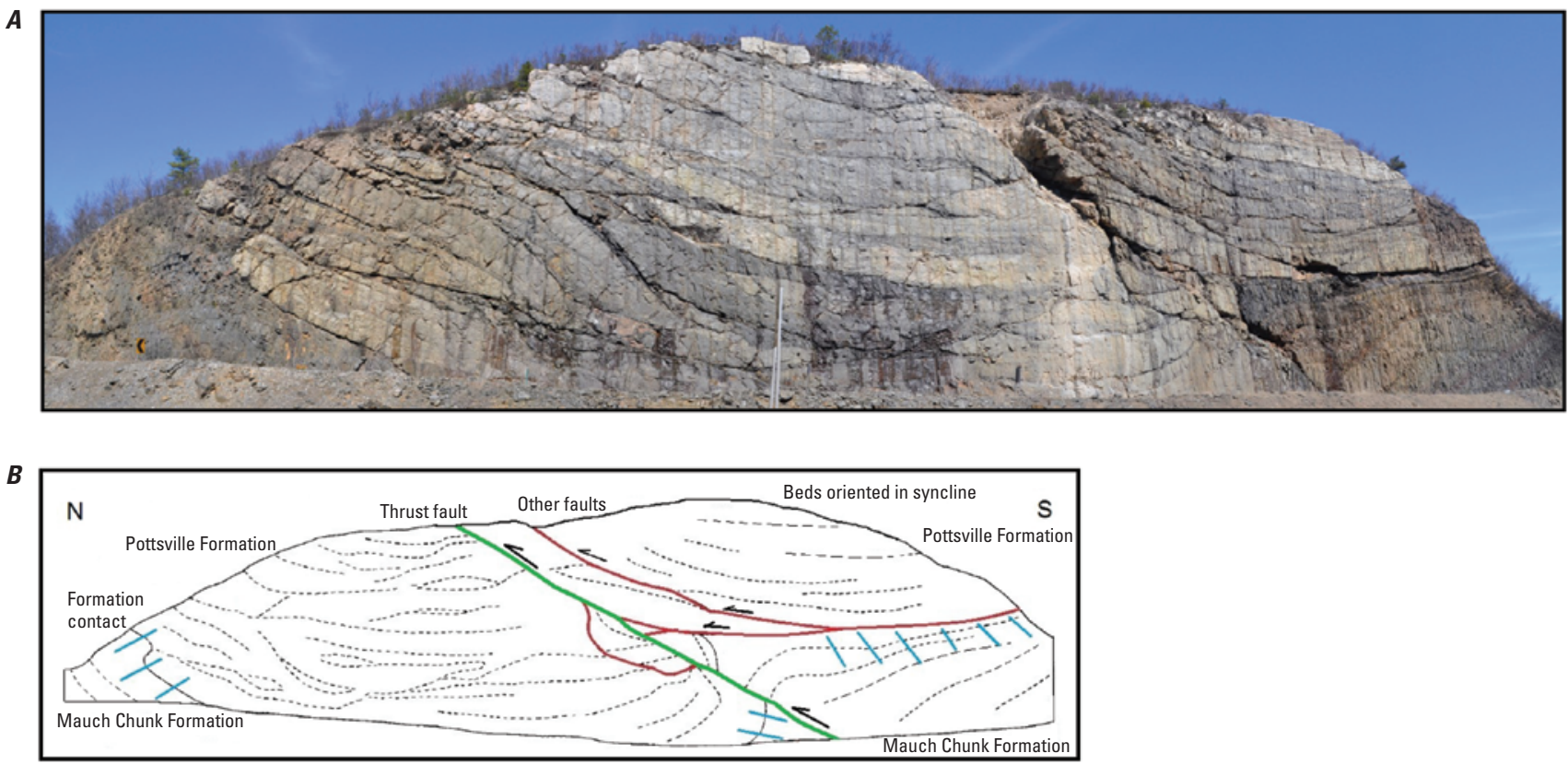

Figure 4. Synclinal structure, faults, and contact between the Pottsville Formation and underlying Mauch Chunk Formation on Spring Mountain, Schuylkill County, Pennsylvania as shown in A, a photograph looking east-northeast at the 850-foot (ft)-long, 110 -ft-high Interstate 81 roadcut (along the northbound lanes), and $B$, a diagram of the exposure, where the green line indicates a thrust fault, red lines indicate other faults, black arrows show direction of movement, and blue hachures indicate the transition between lighter-colored Pottsville Formation and darker Mauch Chunk Formation. Modified from Reese (2016). Photograph by Photograph by Thomas G. Whitfield, Pennsylvania Geological Survey, from Reese (2016). Location of Spring Mountain road cut shown on figure 2. 
A. Northwest-to-southeast topographic profile

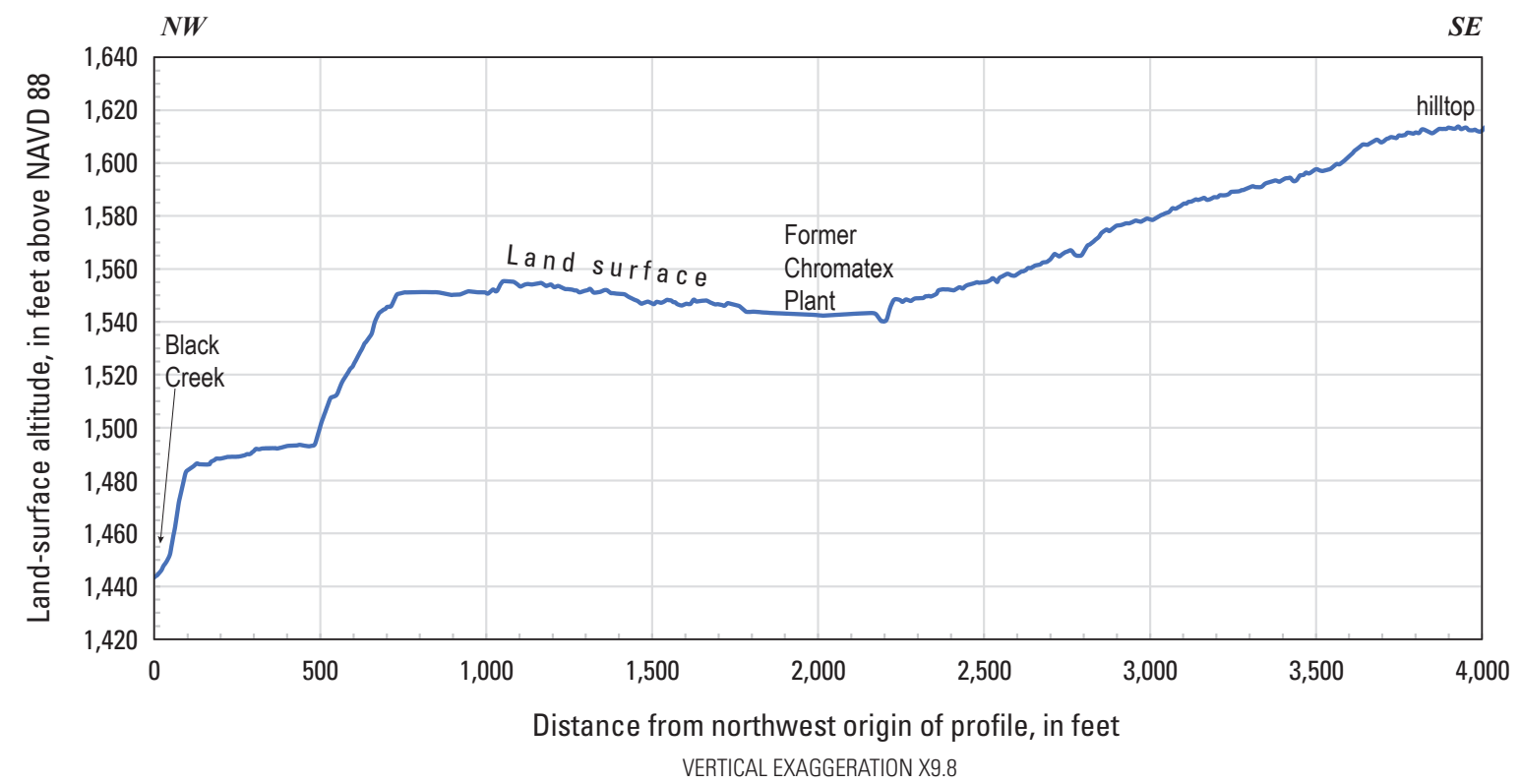

VERTICAL EXAGGERATION X9.8

\section{B. Southwest-to-northeast topographic profile}

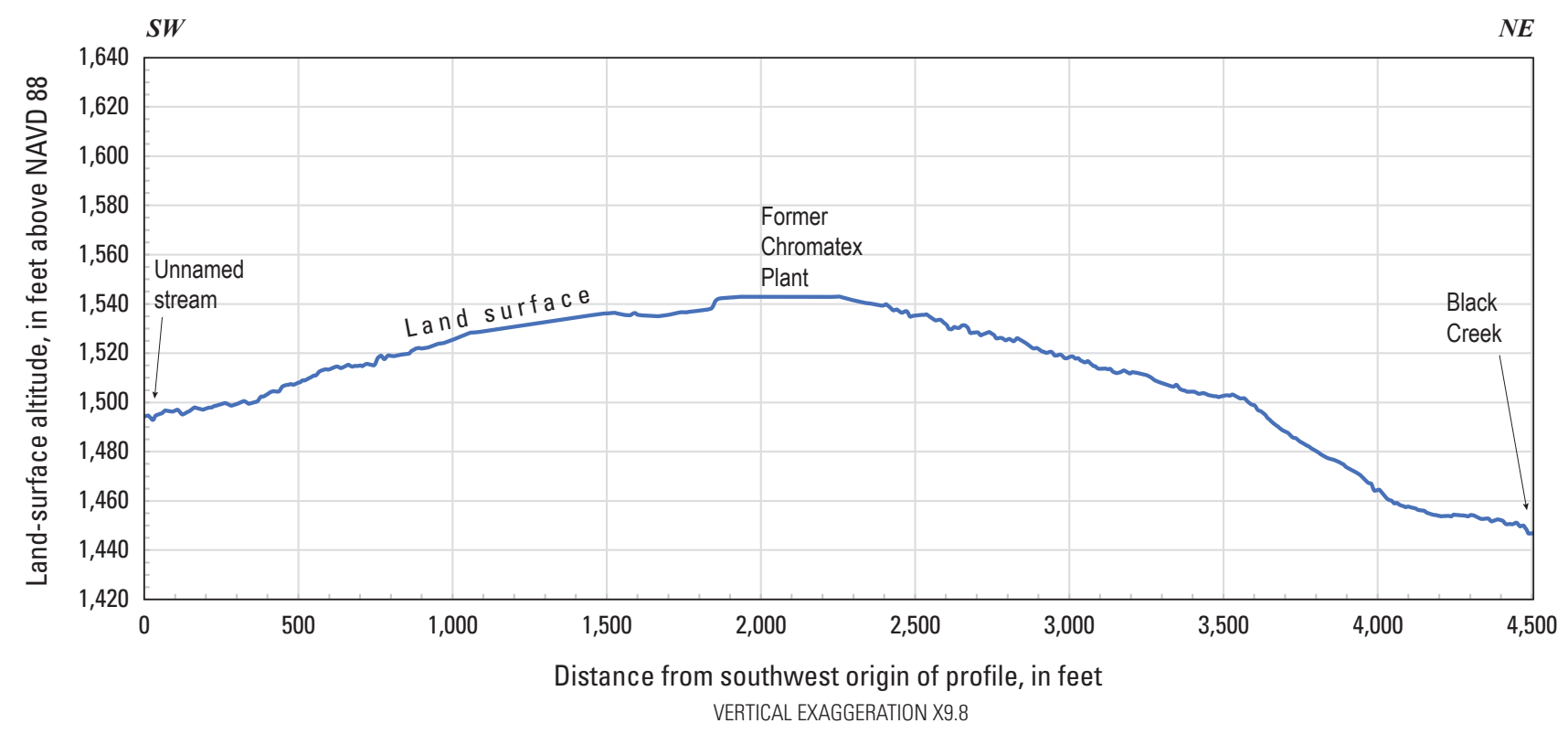

Figure 5. Graphs showing $A$, northwest-to-southeast (NW-SE) and $B$, southwest-to-northeast (SW-NE) trending topographic profiles of land-surface altitudes at and near the Valmont TCE Superfund Site. Land-surface altitudes, in feet above NAVD 88, for topographic profiles from 1-meter digital elevation model (Pennsylvania Spatial Data Access, 2015). Location of profile lines shown (in pink) on figure 1. 
in valley settings. Complex geologic structure as well as fracture distribution and orientation may affect groundwater-flow directions locally.

The general groundwater hydrology of Luzerne County has been described by Newport (1977). Precipitation is distributed nearly evenly through the year, but recharge is greatest from fall to spring each year; among other potential seasonal factors than can affect recharge, such as rainfall intensity and soil moisture conditions, evapotranspiration rates are lower in those months compared to summer months. Groundwater levels in central and eastern Pennsylvania fluctuate seasonally. In USGS long-term observation wells in Luzerne County and nearby counties in similar settings (Carbon, Monroe, and Schuylkill Counties), water levels typically are highest in the months of March and April and lowest in the months of September and October (U.S. Geological Survey, 2021a). Long-term (1970-2020) daily median levels for the observation well closest to study area, CB-104, a 125-ftdeep borehole completed in the Mauch Chunk Formation and located about $15.8 \mathrm{mi}$ to the northeast of Valmont TCE Superfund Site (fig. 2), indicate seasonal fluctuations of about $35 \mathrm{ft}$, with depth to water about $35 \mathrm{ft}$ bls in early spring and $70 \mathrm{ft}$ bls in early fall (fig. 6A). The range of seasonal fluctuations in groundwater levels may be affected by several factors other than precipitation and evapotranspiration, including topographic setting, aquifer properties, and depth of observation. Some of these factors also affect the apparent depth to water below land surface in the aquifer.

Seasonal fluctuations in recharge are correspondingly reflected in seasonal fluctuations in groundwater discharge, as shown by computed monthly base flow (fig. $6 \mathrm{~B}$ ) at a small stream with a USGS streamgage (01538000 Wapwallopen Creek near Wapwallopen, PA) near the Site (fig. 2). Base flow (fig. $6 B$ ) was computed using the local-minimum option in

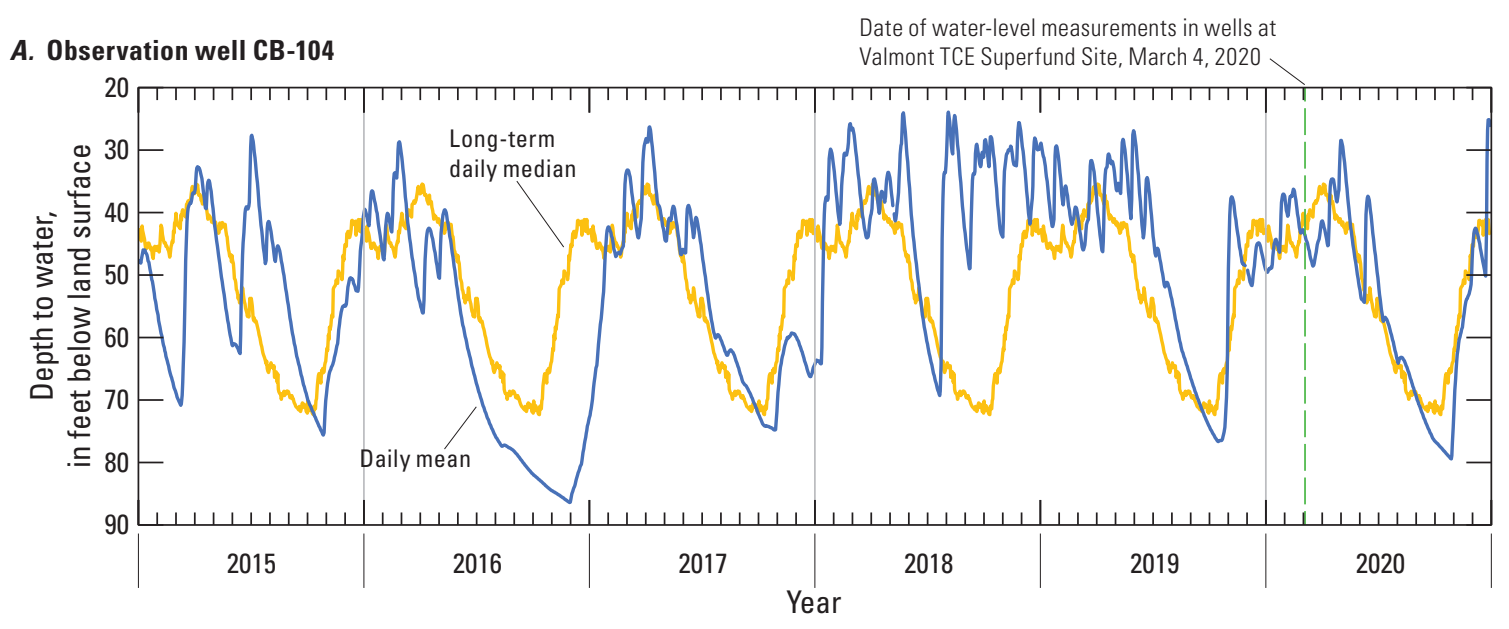

B. Station 01538000 Wapwollopen Creek

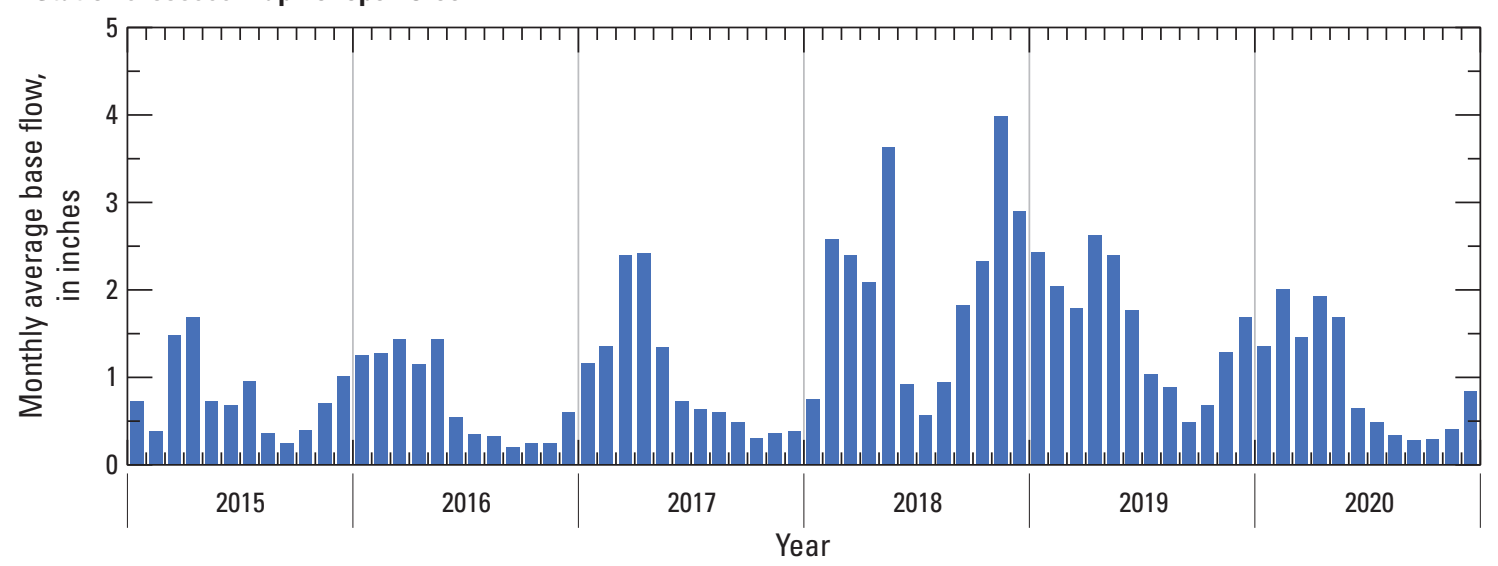

Figure 6. Graphs showing $A$, Long-term (1970-2020) daily median and 2015-20 daily mean water levels in U.S. Geological Survey (USGS) observation well CB-104 in Carbon County, Pennsylvania, and B, computed monthly average 2015-20 base flow at USGS streamgage 01538000 Wapwallopen Creek near Wapwallopen, PA. Base flow computed using the local-minimum option in HYSEP (Sloto and Crouse, 1986) for daily streamflow values. The date of recent water-level measurements in wells at Valmont TCE Superfund Site, March 4, 2020, is shown on graph of water levels in observation well CB-104 to indicate regional conditions at that time. 
HYSEP (Sloto and Crouse, 1986) for daily streamflow values measured at the streamgage. Wapwallopen Creek drains 43.8 square miles $\left(\mathrm{mi}^{2}\right)$ at USGS gage 01538000 , which is about $7.4 \mathrm{mi}$ northwest of Valmont TCE Superfund Site (fig. 2).

Base flow (groundwater discharge to streams) can be used to estimate recharge. Long-term (1980-2020) median annual base flow computed using the same method as used for monthly values at streamgage 01538000 Wapwallopen Creek near Wapwallopen, PA, is about 12 inches per year. However, the geology of the Wapwallopen Creek drainage area (glaciated and underlain by Devonian shales, siltstones, and sandstones [Berg and others, 1980]) and land use (forested and agricultural) differs from the geology (unglaciated sandstones and siltstones) and land use (industrial and residential) in the immediate vicinity of the Valmont TCE Superfund Site, and thus, estimates of recharge from base flow for Wapwallopen Creek, although nearby, may differ from actual recharge at the Site, as natural and anthropogenic factors that may affect recharge differ.

Groundwater has been a source for drinking water and industrial supply in the area near the Valmont TCE Superfund Site. Although the residential wells nearest the Site are no longer in use, any withdrawals from other nearby production wells may affect the direction of groundwater flow. The evaluation of current (2020) water use is beyond the scope of this report.

\section{Hydrogeologic Framework, Water Levels, and Selected Contaminant Concentrations}

The hydrogeologic framework was refined using information about lithology (from video, geophysical, and drillers logs), geologic structure, and water-bearing zones from geophysical and video logs for individual wells, geophysical log correlation among wells, and distribution of water levels to determine vertical and horizontal hydraulic gradients at the Valmont TCE Superfund Site. Additionally, concentrations of selected contaminants at the site, TCE and PFAS, are displayed with the hydrogeologic framework to provide information on relations between the distribution of observed contamination and the hydrogeologic framework. The distribution of wells at the Site with logs used for correlations are shown in figure 7.

\section{Geophysical Logs, Lithology, Structure, and Water-Bearing Zones}

Geophysical logs were collected in wells at the Valmont TCE Superfund Site at various times from 2002 to 2014 by USGS and EPA contractors (Tetra Tech NUS, Inc., 2004b,
2010, 2011, 2014, 2016). If two wells were drilled in a cluster, logs for the deepest well of the cluster are used for this study. Geophysical logs for a total of 44 wells were compiled for the study. Digital log data for these wells, except wells MW-1C and MW-3 for which only paper logs were available (Tetra Tech NUS, Inc., 2004b), are archived and identified by USGS station number in the USGS GeoLog Locator database (U.S. Geological Survey, 2021b). Local well names assigned by the EPA and USGS, USGS station numbers, description of well characteristics at the time of logging, and type of logs collected in each well evaluated as part of this study are listed in tables 1 and 2. Local well names assigned by the EPA will be used to identify wells in this report. Logs were collected in open boreholes named as listed in table 2. Most open boreholes were later reconstructed with one or more screens and renamed to designate relative depths of shallow (S), intermediate (I), or deep (D). The depths of the 44 open-borehole wells at the time of logging ranged from 47 to $400 \mathrm{ft} \mathrm{bls,} \mathrm{with}$ total depth for most boreholes ranging from 100 to $150 \mathrm{ft}$ bls (table 2). The five deepest open boreholes included MW-19D, MW-29, MW-7, MW-22 (former production well PW-1), and MW-27, which had depths of 250, 251, 299, 377, and $400 \mathrm{ft}$ bls, respectively.

Drilling logs indicate that, for most wells, the depth to the top of weathered bedrock (bottom of overburden) ranged from 1 to $15 \mathrm{ft}$ bls and the depth to the top of competent bedrock ranged from 5 to $37 \mathrm{ft}$ bls (table 2) (Tetra Tech NUS, Inc., 2004b, 2010, 2011, 2014, 2016). Casing was generally installed $5 \mathrm{ft}$ or more into competent bedrock, except for some shallow wells including MW-32S, MW-33S, MW-34S and MW-35S, which were screened partly in weathered rock (Tetra Tech NUS, Inc., 2016). The reported depth to competent bedrock in drillers logs was greater in four wells (ranging from 20 to $37 \mathrm{ft}$ in wells MW-17, MW-25, E-9, and MW-13D) than typical for other wells at the Site, and casing lengths for these wells (ranging from 25 to $50 \mathrm{ft}$ ) were consequently greater than typical for most wells at the Site (table 2). The reported depth to water at the time of logging ranged from about 6 to $40.68 \mathrm{ft}$ bls in 44 wells with logs (table 2).

\section{Geophysical Logs and Lithology}

The natural gamma, single-point resistance, and borehole neutron density logs used in this study record differences in borehole characteristics that can be related to lithology. Additionally, optical televiewer (OTV) logs depicting flattened images of borehole walls (with north at the left and right edges of the image and south in the center of the image) and video logs can be used to help identify rock types. Acoustic televiewer (ATV) logs collected in conjunction with OTV logs provide information about fracture locations and orientations by emitting an acoustic wave that reflects off the borehole wall and returns to the tool, providing an image of the travel time and (or) amplitude of that response. Longer travel times indicate wider portions of the borehole typically caused by fractures. 


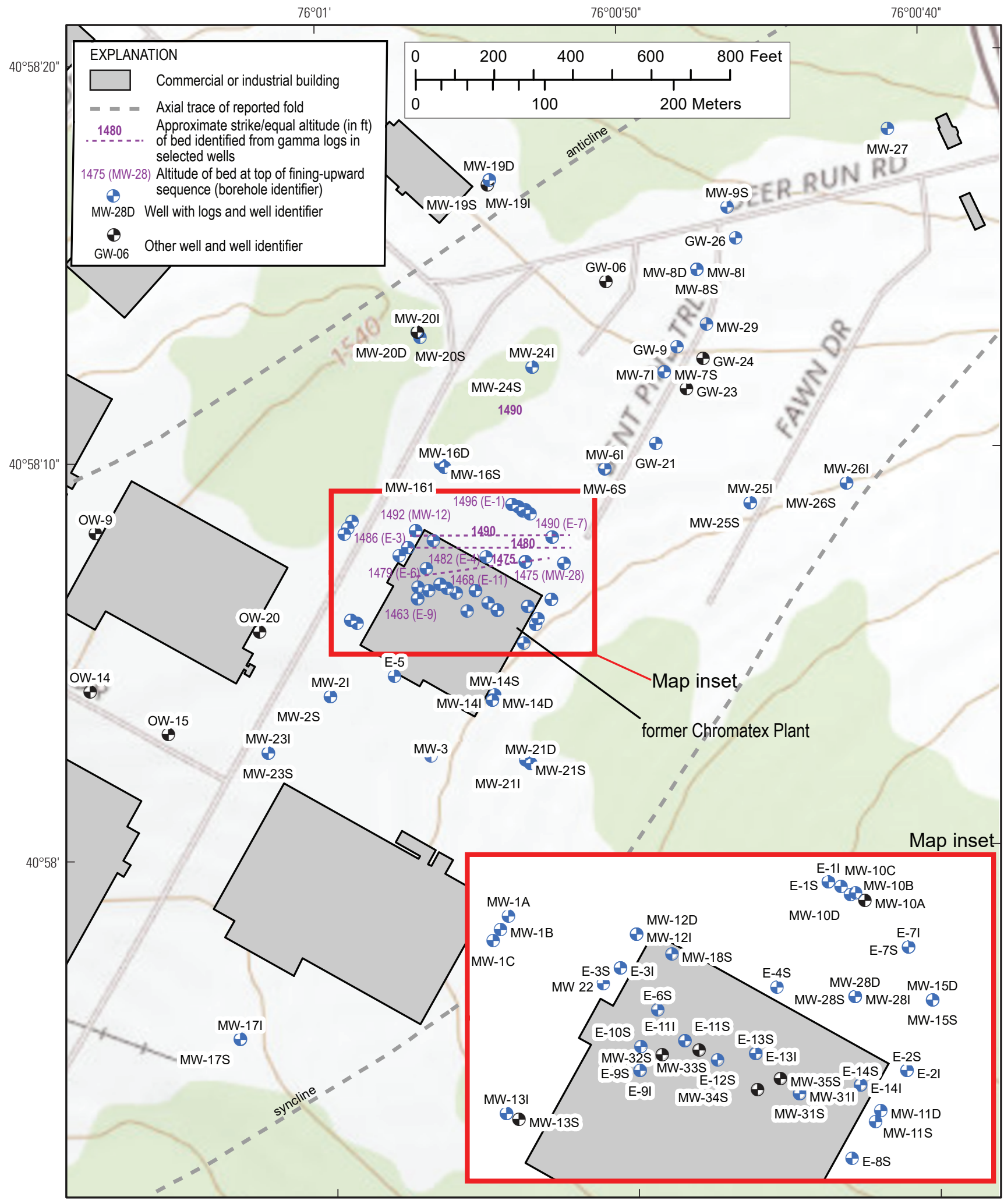

Base from U.S. Geological Survey, The National Map

Figure 7. Location of wells with geophysical logs used for correlation and other wells at and near the Valmont TCE Superfund Site, Luzerne County, Pennsylvania. Estimated altitude of the top of a fining-upward sequence identified from geophysical logs are shown for selected wells. Geologic structure from Schasse and others (2012), with mapped approximate location of fold axes shown by dashed gray lines. 
Table 1. Local well names assigned by the U.S. Environmental Protection Agency (EPA) and U.S. Geological Survey (USGS); USGS station numbers; source, date, depth, section line for display; and type of geophysical logs in open-borehole wells used for correlation at and near the Valmont TCE Superfund Site, Luzerne County, Pennsylvania. Section lines shown on figure 15.

[GAM, natural gamma; SPR, single-point resistance; DEN, density; ATV, acoustic televiewer; OTV, optical televiewer; VID, video; ft, feet; bls, below land surface; --, no data; X, log type used in cross section; O, log type available but quality deemed too poor for inclusion; U, log type available but not used in cross section; I, log type indirectly used in cross section]

\begin{tabular}{|c|c|c|c|c|c|c|c|c|c|c|c|}
\hline \multirow{2}{*}{$\begin{array}{c}\text { EPA local name } \\
\text { for well and } \\
\text { (or) borehole } \\
\text { nest }\end{array}$} & \multirow[b]{2}{*}{$\begin{array}{l}\text { USGS station } \\
\text { number }\end{array}$} & \multirow{2}{*}{$\begin{array}{c}\text { USGS } \\
\text { local well } \\
\text { name }\end{array}$} & \multirow{2}{*}{$\begin{array}{c}\text { Source and } \\
\text { date (year) of } \\
\operatorname{logs}^{1}\end{array}$} & \multirow{2}{*}{$\begin{array}{l}\text { Drilled well } \\
\text { and log } \\
\text { depth, } \\
\text { in ft bls }\end{array}$} & \multirow[b]{2}{*}{$\begin{array}{l}\text { Line of } \\
\text { section }\end{array}$} & \multicolumn{6}{|c|}{ Type of log } \\
\hline & & & & & & GAM & SPR & DEN & ATV & OTV & VID $^{2}$ \\
\hline E-1 & 405809076005401 & LU-781 & 2009 & 150 & B-B' & $\mathrm{X}$ & $\mathrm{X}$ & $\mathrm{X}$ & $\mathrm{X}$ & $\mathrm{X}$ & -- \\
\hline E-2 & 405806076005302 & LU-782 & 2009 & 150 & $\mathrm{C}-\mathrm{C}^{\prime}$ & $\mathrm{X}$ & $\mathrm{X}$ & $\mathrm{X}$ & $\mathrm{X}$ & $\mathrm{X}$ & -- \\
\hline E-3 & 405808076005702 & LU-783 & 2009 & 150 & A-A'; E-E'; F-F' & $\mathrm{X}$ & $\mathrm{X}$ & $\mathrm{X}$ & $\mathrm{X}$ & $\mathrm{X}$ & -- \\
\hline E-4 & 405807076005501 & LU-784 & 2009 & 150 & B-B'; F-F' & $\mathrm{X}$ & $\mathrm{X}$ & $\mathrm{X}$ & $\mathrm{X}$ & $\mathrm{X}$ & -- \\
\hline E-5 & 405805076005801 & LU-785 & 2009 & 150 & B-B' & $\mathrm{X}$ & $\mathrm{X}$ & $\mathrm{X}$ & $\mathrm{X}$ & $\mathrm{X}$ & -- \\
\hline E-6 & 405807076005702 & LU-786 & 2009 & 150 & E-E' & $\mathrm{X}$ & $\mathrm{X}$ & $\mathrm{X}$ & $\mathrm{X}$ & $\mathrm{X}$ & -- \\
\hline E-7 & 405808076005201 & LU-787 & 2011 & 150 & F-F' & $\mathrm{X}$ & $\mathrm{X}$ & -- & $\mathrm{O}$ & -- & -- \\
\hline E-8 & 405805076005301 & LU-788 & 2011 & 150 & $\mathrm{C}-\mathrm{C}^{\prime}$ & $\mathrm{X}$ & -- & -- & $\mathrm{O}$ & -- & -- \\
\hline E-9 & 405806076005702 & LU-789 & 2011 & 150 & B-B' & $\mathrm{X}$ & $\mathrm{X}$ & -- & $\mathrm{O}$ & -- & -- \\
\hline E-10 & 405809076005701 & LU-790 & 2014 & 100 & B-B' & $\mathrm{X}$ & $\mathrm{X}$ & -- & -- & -- & -- \\
\hline E-11 & 405807076005602 & LU-791 & 2014 & 100 & B-B'; E-E' & $\mathrm{X}$ & $\mathrm{X}$ & -- & -- & -- & -- \\
\hline E-12 (MW-30) & 405807076005603 & LU-792 & 2014 & 100 & E-E' & $\mathrm{X}$ & $\mathrm{X}$ & -- & $\mathrm{X}$ & -- & -- \\
\hline E-13 & 405807076005502 & LU-793 & 2014 & 76 & E-E' & $\mathrm{X}$ & $\mathrm{X}$ & -- & -- & -- & -- \\
\hline E-14 & 405806076005303 & LU-794 & 2014 & 100 & $\mathrm{C}-\mathrm{C}^{\prime}$ & $\mathrm{X}$ & $\mathrm{X}$ & -- & -- & -- & -- \\
\hline MW-1C & 405808076005901 & LU-795 & Paper RI 2002 & 111 & E-E' & $\mathrm{X}$ & -- & -- & -- & -- & -- \\
\hline MW-2i & 405804076010001 & LU-796 & 2009 & 80 & A-A'; B-B' & $\mathrm{X}$ & $\mathrm{X}$ & $\mathrm{X}$ & $\mathrm{X}$ & $\mathrm{X}$ & -- \\
\hline MW-3 & 405802076005701 & LU-797 & Paper RI 2002 & 47 & D-D' & $\mathrm{X}$ & -- & -- & -- & -- & -- \\
\hline MW-6 & 405808076004601 & LU-764 & 2002 & 208 & B-B'; C-C'; G-G' & $\mathrm{X}$ & $\mathrm{X}$ & -- & -- & -- & U \\
\hline MW-7 & 405811076004901 & LU-759 & 2002 & 299 & B-B' & $\mathrm{X}$ & $\mathrm{X}$ & -- & -- & -- & $\mathrm{U}$ \\
\hline MW-8 & 405814076004901 & LU-761 & 2002 & 150 & B-B' & $\mathrm{X}$ & -- & -- & -- & -- & $\mathrm{U}$ \\
\hline MW-9 & 405816076004601 & LU-763 & 2002 & 110 & B-B'; H-H' & $\mathrm{X}$ & $\mathrm{X}$ & -- & -- & -- & U \\
\hline MW-10C & 405808076005401 & LU-767 & 2002 & 129 & B-B' & $\mathrm{X}$ & $\mathrm{X}$ & -- & -- & -- & -- \\
\hline MW-11D & 405806076005301 & LU-755 & 2002 & 150 & C-C'; E-E' & $\mathrm{X}$ & $\mathrm{X}$ & -- & -- & -- & I \\
\hline MW-12D & 405808076005701 & LU-756 & 2002 & 150 & $\mathrm{~A}-\mathrm{A}^{\prime}$ & $\mathrm{X}$ & $\mathrm{X}$ & -- & -- & -- & U \\
\hline MW-13D & 405806076005901 & LU-762 & 2002 & 150 & A-A'; B-B' & $\mathrm{X}$ & $\mathrm{X}$ & -- & -- & -- & $\mathrm{U}$ \\
\hline MW-14D2 & 405804076005502 & LU-766 & 2002 & 166 & $\mathrm{C}-\mathrm{C}^{\prime}$ & $\mathrm{X}$ & $\mathrm{X}$ & -- & -- & -- & I \\
\hline MW-15D & 405807076005201 & LU-765 & 2002 & 150 & $\mathrm{C}-\mathrm{C}^{\prime}$ & $\mathrm{X}$ & $\mathrm{X}$ & -- & -- & -- & I \\
\hline MW-16D & 405810076005501 & LU-757 & 2002 & 150 & A-A' & $\mathrm{X}$ & $\mathrm{X}$ & -- & -- & -- & $\mathrm{U}$ \\
\hline MW-17D & 405755076010301 & LU-752 & 2002 & 150 & A-A' & $\mathrm{X}$ & $\mathrm{X}$ & -- & -- & -- & $\mathrm{U}$ \\
\hline MW-18 & 405806076005701 & LU-775 & 2003 & 77 & $F-F^{\prime}$ & $\mathrm{X}$ & $\mathrm{X}$ & -- & $\mathrm{O}$ & -- & -- \\
\hline MW-19D & 405817076005401 & LU-769 & 2002 & 250 & A-A'; H-H' & $\mathrm{X}$ & $\mathrm{X}$ & -- & -- & -- & I \\
\hline MW-20D & 405813076005601 & LU-758 & 2002 & 150 & G-G' & $\mathrm{X}$ & $\mathrm{X}$ & -- & -- & -- & $\mathrm{U}$ \\
\hline MW-21D & 405802076005301 & LU-753 & 2002 & 150 & D-D' & $\mathrm{X}$ & $\mathrm{X}$ & -- & -- & -- & U \\
\hline MW-22 (PW-1) & 405807076005701 & LU-750 & 2002 & 377 & $\mathrm{~A}-\mathrm{A}^{\prime}$ & $\mathrm{X}$ & $\mathrm{X}$ & -- & -- & -- & U \\
\hline MW-23 & 405803076010201 & LU-770 & 2003 & 100 & A-A'; D-D' & $\mathrm{X}$ & $\mathrm{X}$ & -- & -- & -- & -- \\
\hline MW-24 & 405812076005301 & LU-771 & 2003 & 100 & A-A'; G-G' & $\mathrm{X}$ & $\mathrm{X}$ & -- & -- & -- & -- \\
\hline MW-25 & 405809076004601 & LU-772 & 2003 & 104 & G-G' & $\mathrm{X}$ & $\mathrm{X}$ & -- & -- & -- & -- \\
\hline MW-26 & 405809076004301 & LU-777 & 2003 & 125 & G-G' & $\mathrm{X}$ & $\mathrm{X}$ & -- & -- & -- & -- \\
\hline MW-27 & 405816076004101 & LU-773 & 2003 & 400 & B-B'; H-H' & $\mathrm{X}$ & $\mathrm{X}$ & -- & -- & -- & -- \\
\hline MW-28D & 405807076004801 & LU-798 & 2009 & 150 & $\mathrm{~F}-\mathrm{F}^{\prime}$ & $\mathrm{X}$ & $\mathrm{X}$ & $\mathrm{X}$ & $\mathrm{X}$ & $\mathrm{X}$ & -- \\
\hline MW-29 & 405813076004801 & LU-799 & 2009 & 251 & B-B' & $\mathrm{X}$ & -- & $\mathrm{X}$ & $\mathrm{X}$ & $\mathrm{X}$ & -- \\
\hline
\end{tabular}


Table 1. Local well names assigned by the U.S. Environmental Protection Agency (EPA) and U.S. Geological Survey (USGS); USGS station numbers; source, date, depth, section line for display; and type of geophysical logs in open-borehole wells used for correlation at and near the Valmont TCE Superfund Site, Luzerne County, Pennsylvania. Section lines shown on figure 15.-Continued

[GAM, natural gamma; SPR, single-point resistance; DEN, density; ATV, acoustic televiewer; OTV, optical televiewer; VID, video; ft, feet; bls, below land surface; --, no data; $\mathrm{X}, \log$ type used in cross section; $\mathrm{O}, \log$ type available but quality deemed too poor for inclusion; $\mathrm{U}$, log type available but not used in cross section; I, log type indirectly used in cross section]

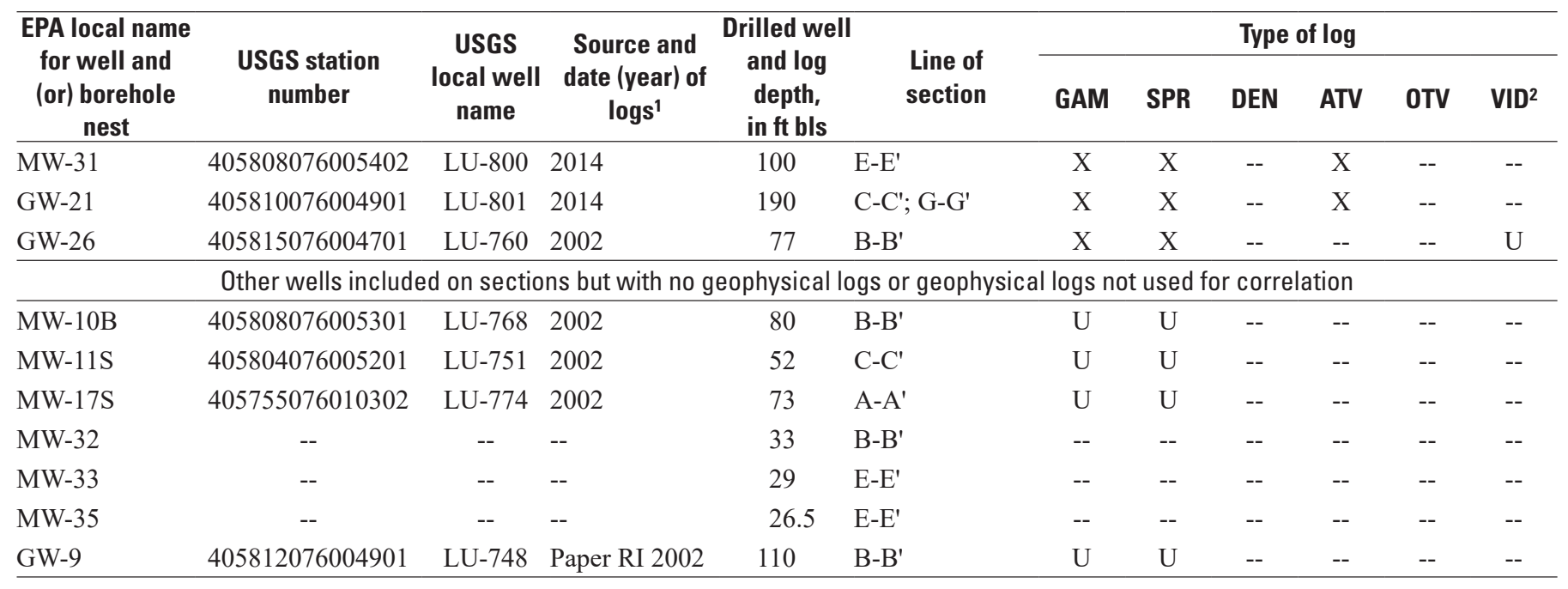

${ }^{1}$ Log sources: 2009 logs in Tetra Tech NUS, Inc. (2010); 2011 logs in Tetra Tech NUS, Inc. (2011); 2014 logs in Tetra Tech NUS, Inc. (2014); 2002 and 2003 logs, collected by USGS unless noted as Paper RI 2002, in Tetra Tech NUS, Inc. (2004b); Paper RI 2002, log only on paper in Tetra Tech NUS, Inc. (2004b).

${ }^{2}$ Dates of video logs collection by USGS were August 19-20, 2002 and September 11-12, 2002.

At the Valmont TCE Superfund Site, lithologies predominantly consist of sandstone and conglomerate, with lesser amounts of siltstone and shale and some thin coal beds as reported in driller's logs for the boreholes (Tetra Tech NUS, Inc., 2004b, 2010, 2011, 2014, 2016). Owing to the time lag between drill depth and surfacing of cuttings, the depths of lithologies as reported on drillers logs are only approximate, and thus, are used only qualitatively in the evaluation of geophysical logs for this study. Variation in different geologists' description of drill cuttings collected during different periods introduces additional uncertainty to consider in use of the drillers' logs to identify lithology, and a formal review of these variations was not done for this study.

Sedimentary rocks, which commonly include shales, mudstones, and other argillaceous units, have relatively high natural gamma radiation and low resistivity when compared to other lithologic units largely as a result of the abundance of clay minerals in those rock types. Major natural-gamma emitters are uranium, thorium, and daughter products of potassium-40. Potential sources of natural gamma radiation in fine-grained sediments such as shales include potassium40-bearing clay minerals (Keys, 1990). Uranium may be enriched in organic-rich black shales (Swanson, 1961) but also sometimes can be enriched in sandstones and other sedimentary rocks, depending on depositional and post-depositional geochemical environments. Coal typically can be identified by its low-density, about 0.7 to 1.8 grams per cubic centimeter $\left(\mathrm{g} / \mathrm{cm}^{3}\right)$, on borehole density logs and commonly is associated with low radioactivity, although locally it may be uraniferous (Wood and others, 1983).

At the Valmont TCE Superfund Site, sandstone and conglomerate lithologies, as reported on drillers' logs and depicted on OTV and video logs, are associated with intervals of relatively low natural gamma activity and relatively high single-point resistance on the logs, reflecting a low abundance of gamma-emitting clay minerals, which increase electrical conductivity when present in rocks. Conversely, shale, mudstone, and other argillaceous rocks are associated with intervals of relatively high natural gamma activity and relatively low single-point resistance on the logs, reflecting a higher abundance of gamma-emitting clay minerals (and possibly other radioactive elements in the shales). The geophysical logs do not provide information to readily differentiate sandstone from conglomerate at the Site (although the natural gamma activity appears to be slightly lower in intervals of conglomerate than of sandstone), but differences in these rock types can be seen on OTV and video logs. An example of the natural gamma log for well MW-12D with sandstone, conglomerate, and coal beds identified on geologist logs during drilling is shown in figure 8. 
Table 2. Characteristics of open-borehole wells with geophysical logs used for correlation and of other wells without logs at and near the Valmont TCE Superfund Site, Luzerne County, Pennsylvania. Well characteristics from Tetra Tech NUS, Inc. (2004b, 2010, 2011, 2014, 2016) and International Exploration, Inc. (1989).

[EPA, U.S. Environmental Protection Agency; ft, feet; bls, below land surface; NAVD 88, North American Vertical Datum 1988; , indicates value estimated from available data. ?, uncertain value; --, no data]

\begin{tabular}{|c|c|c|c|c|c|c|c|c|c|}
\hline \multirow[b]{2}{*}{$\begin{array}{c}\text { EPA local } \\
\text { name for } \\
\text { open-borehole } \\
\text { wella }\end{array}$} & \multirow[b]{2}{*}{$\begin{array}{l}\text { USGS } \\
\text { local well } \\
\text { name }\end{array}$} & \multirow[b]{2}{*}{$\begin{array}{c}\text { Land } \\
\text { surface } \\
\text { altitude, } \\
\text { in ft above } \\
\text { NAVD } 88\end{array}$} & \multirow[b]{2}{*}{$\begin{array}{l}\text { Borehole } \\
\text { diameter, } \\
\text { in inches }\end{array}$} & \multicolumn{5}{|c|}{ Reported depths or lengths, in ft bls } & \multirow[b]{2}{*}{$\begin{array}{l}\text { Date of log } \\
\text { (M/D/Y) }\end{array}$} \\
\hline & & & & $\begin{array}{l}\text { Depth to } \\
\text { weathered } \\
\text { bedrock }\end{array}$ & $\begin{array}{l}\text { Depth to } \\
\text { competent } \\
\text { bedrock }\end{array}$ & $\begin{array}{l}\text { Casing } \\
\text { length }\end{array}$ & $\begin{array}{c}\text { Drilled } \\
\text { well depth }\end{array}$ & $\begin{array}{c}\text { Depth to } \\
\text { water at } \\
\text { the time of } \\
\text { logging }\end{array}$ & \\
\hline E-1 & LU-781 & $1,538.20$ & 8 & 7 & 9 & 19 & 150 & 16.5 & $5 / 4 / 2009$ \\
\hline E-2 & LU-782 & $1,538.40$ & 8 & 5 & 8 & 19 & 150 & $\sim 6$ & $5 / 8 / 2009$ \\
\hline E-3 & LU-783 & $1,542.72$ & 8 & 5 & 8 & 19 & 150 & $\sim 22$ & $5 / 4 / 2009$ \\
\hline E-4 & LU-784 & $1,541.98$ & 8 & 9 & 9 & 19 & 150 & 19.6 & $5 / 11 / 2009$ \\
\hline E-5 & LU-785 & $1,542.51$ & 8 & 4 & 8 & 19 & 150 & 12 & $5 / 7 / 2009$ \\
\hline E-6 & LU-786 & $1,543.18$ & 8 & 6 & 9 & 19 & 150 & $\sim 20$ & $5 / 12 / 2006$ \\
\hline E-7 & LU-787 & $1,537.98$ & 8 & 7 & 10 & 19 & 150 & $\sim 15$ & 2011 \\
\hline E-8 & LU-788 & $1,542.79$ & 8 & 4 & 6 & 19 & 150 & $\sim 12$ & 2011 \\
\hline E-9 & LU-789 & $1,543.30$ & 8 & 5 & $24 ?$ & 29.5 & 150 & $\sim 9$ & 2011 \\
\hline E-10 & LU-790 & $1,542.80^{\mathrm{b}}$ & 6 & 8 & 13 & 20.5 & 100 & 16 & $8 / 21 / 2014$ \\
\hline E-11 & LU-791 & $1,542.75^{b}$ & 6 & 9 & 14 & 20.5 & 100 & 17 & $8 / 21 / 2014$ \\
\hline E-12 (MW-30) & LU-792 & $1,542.92^{\mathrm{b}}$ & 8 & 9 & 16 & 22 & 100 & 12 & $6 / 24 / 2014$ \\
\hline E-13 & LU-793 & $1,542.95^{\mathrm{b}}$ & 6 & 8 & 12 & 20.5 & 76 & 21 & $8 / 21 / 2014$ \\
\hline E-14 & LU-794 & $1,540.25^{\mathrm{b}}$ & 6 & 4 & 15 & 20.5 & 100 & 10 & $8 / 21 / 2014$ \\
\hline MW-1C & LU-795 & $1,547.30$ & 4 & 3 & 22 & 86.5 & 111 & $\sim 36$ & 2002 \\
\hline MW-2i & LU-796 & $1,535.96$ & 6 & 1 & 5 & 15 & 80 & $\sim 9$ & $5 / 4 / 2009$ \\
\hline MW-3 & LU-797 & $1,535.73$ & 6 & 4 & 13 & 18 & 47 & $\sim 32$ & 2002 \\
\hline MW-6 & LU-764 & $1,534.70$ & 6 & -- & -- & -- & 208 & 25.63 & $9 / 4 / 2002$ \\
\hline MW-7 & LU-759 & $1,525.25$ & 6 & -- & -- & -- & 299 & 22.53 & $8 / 26 / 2002$ \\
\hline MW-8 & LU-761 & $1,514.44$ & 6 & -- & -- & -- & 150 & 25.55 & $8 / 28 / 2002$ \\
\hline MW-9 & LU-763 & $1,507.75$ & 6 & -- & -- & -- & 110 & 18.83 & $9 / 3 / 2002$ \\
\hline MW-10C & LU-767 & $1,538.33$ & 6 & 9 & 24 & 27.5 & 129 & 27.65 & $9 / 17 / 2002$ \\
\hline MW-11D & LU-755 & $1,539.03$ & 6 & 4 & 10 & 20 & 150 & 16.71 & $9 / 13 / 2002$ \\
\hline MW-12D & LU-756 & $1,542.92$ & 6 & 5 & 9 & 19 & 150 & 31.18 & 8/7/2002 \\
\hline MW-13D & LU-762 & $1,540.63$ & 6 & 7 & 37 & 50 & 150 & 24.93 & $8 / 29 / 2002$ \\
\hline MW-14D & LU-766 & $1,542.60$ & 6 & 4 & 8.5 & 18 & 166 & 18.53 & $9 / 16 / 2002$ \\
\hline MW-15D & LU-765 & $1,537.97$ & 6 & 6 & 13 & 18 & 150 & 11.48 & $7 / 24 / 2002$ \\
\hline MW-16D & LU-757 & $1,539.56$ & 6 & 5 & 12 & 30 & 150 & 27.87 & 8/8/2002 \\
\hline MW-17D & LU-752 & $1,522.00$ & 6 & 15 & 20 & 25 & 150 & 17.4 & $7 / 15 / 2002$ \\
\hline MW-18 & LU-775 & $1,543.19$ & 6 & 9 & 12.2 & -- & 77 & $\sim 21$ & $5 / 28 / 2003$ \\
\hline MW-19D & LU-769 & $1,513.99$ & 6 & 5 & 10 & 20 & 250 & 40.20 & $9 / 17 / 2002$ \\
\hline MW-20D & LU-758 & $1,536.34$ & 6 & 5 & 12.5 & 21 & 150 & 40.68 & $8 / 23 / 2002$ \\
\hline MW-21D & LU-753 & $1,538.47$ & 6 & 4 & 11 & 21 & 150 & 16.75 & $7 / 16 / 2002$ \\
\hline MW-22 (PW-1) & LU-750 & $1,542.86$ & 8 & -- & -- & 21 & 377 & 31.18 & $6 / 26 / 2002$ \\
\hline MW-23 & LU-770 & $1,533.64$ & 6 & 11 & 15 & 24 & 100 & 13.4 & $4 / 23 / 2003$ \\
\hline MW-24 & LU-771 & $1,526.68$ & 6 & 5 & 12 & 22 & 100 & 21.24 & $4 / 24 / 2003$ \\
\hline MW-25 & LU-772 & $1,537.90$ & 6 & 6 & 20 & 29 & 104 & 13.43 & $4 / 30 / 2003$ \\
\hline
\end{tabular}


Table 2. Characteristics of open-borehole wells with geophysical logs used for correlation and of other wells without logs at and near the Valmont TCE Superfund Site, Luzerne County, Pennsylvania. Well characteristics from Tetra Tech NUS, Inc. (2004b, 2010, 2011, 2014, 2016) and International Exploration, Inc. (1989)._-Continued

[EPA, U.S. Environmental Protection Agency; ft, feet; bls, below land surface; NAVD 88, North American Vertical Datum 1988; , indicates value estimated from available data. ?, uncertain value; --, no data]

\begin{tabular}{|c|c|c|c|c|c|c|c|c|c|}
\hline \multirow[b]{2}{*}{$\begin{array}{c}\text { EPA local } \\
\text { name for } \\
\text { open-borehole } \\
\text { wella }\end{array}$} & \multirow[b]{2}{*}{$\begin{array}{c}\text { USGS } \\
\text { local well } \\
\text { name }\end{array}$} & \multirow{2}{*}{$\begin{array}{c}\text { Land } \\
\text { surface } \\
\text { altitude }^{b} \text {, } \\
\text { in ft above } \\
\text { NAVD } 88\end{array}$} & \multirow[b]{2}{*}{$\begin{array}{l}\text { Borehole } \\
\text { diameter, } \\
\text { in inches }\end{array}$} & \multicolumn{5}{|c|}{ Reported depths or lengths, in ft bls } & \multirow[b]{2}{*}{$\begin{array}{l}\text { Date of log } \\
\text { (M/D/Y) }\end{array}$} \\
\hline & & & & $\begin{array}{l}\text { Depth to } \\
\text { weathered } \\
\text { bedrock }\end{array}$ & $\begin{array}{l}\text { Depth to } \\
\text { competent } \\
\text { bedrock }\end{array}$ & $\begin{array}{l}\text { Casing } \\
\text { length }\end{array}$ & $\begin{array}{c}\text { Drilled } \\
\text { well depth }\end{array}$ & $\begin{array}{c}\text { Depth to } \\
\text { water at } \\
\text { the time of } \\
\text { logging }\end{array}$ & \\
\hline MW-26 & LU-777 & $1,536.48$ & 6 & 7 & 13 & 20 & 125 & 11.51 & $5 / 28 / 2003$ \\
\hline MW-27 & LU-773 & $1,494.00^{\mathrm{b}}$ & 6 & -- & -- & $25 ?$ & 400 & 9.88 & $5 / 1 / 2003$ \\
\hline MW-28D & LU-798 & $1,538.80$ & 6 & 6 & 9 & 19 & 150 & 16.5 & $5 / 4 / 2009$ \\
\hline MW-29 & LU-799 & $1,518.86$ & 6 & -- & 9 & 19 & 251 & $\sim 18$ & $5 / 22 / 2009$ \\
\hline MW-31 & LU-800 & $1,542.83$ & 6 & -- & -- & 19 & 100 & 11 & $6 / 25 / 2014$ \\
\hline GW-21 & LU-801 & $1,533.29$ & 6 & -- & -- & -- & 190 & 18 & $6 / 25 / 2014$ \\
\hline GW-26 & LU-760 & $1,510.40$ & 6 & -- & -- & -- & 77 & 21.12 & $8 / 27 / 2002$ \\
\hline \multicolumn{10}{|c|}{ Other wells with logs not used for correlation or with no geophysical logs } \\
\hline MW-10B & LU-768 & $1,537.79$ & 6 & 2 & 15 & 57 & 80 & 26.45 & 9/17/2002 \\
\hline MW-11S & LU-751 & $1,539.07$ & 6 & 4 & 20 & 20 & 52 & 5.73 & $6 / 27 / 2002$ \\
\hline MW-17S & LU-774 & $1,522.09$ & 6 & 15 & 20 & 30 & 73 & 17.28 & $7 / 5 / 2002$ \\
\hline MW-32 & -- & $1,542.93^{\mathrm{b}}$ & 6 & 13 & 19 & 19 & 33 & -- & -- \\
\hline MW-33 & -- & $1,542.94^{b}$ & 6 & 8 & 13 & 13 & 29 & -- & -- \\
\hline MW-34 & -- & $1,542.84^{b}$ & 6 & 5 & 7 & 7 & 26.5 & -- & -- \\
\hline MW-35 & -- & $1,543.08^{b}$ & 6 & 4 & 8.5 & 8.5 & 26.5 & -- & -- \\
\hline GW-6 & -- & $1,517.38^{b}$ & -- & -- & -- & -- & 92 & -- & -- \\
\hline GW-9 & LU-748 & $1,522.63^{b}$ & 6 & -- & -- & -- & 110 & -- & -- \\
\hline GW-23 & -- & $1,526.80^{\mathrm{b}}$ & -- & -- & -- & -- & 180 & -- & -- \\
\hline GW-24 & -- & $1,522.18^{b}$ & -- & -- & -- & -- & 190 & -- & -- \\
\hline DL01 & -- & $1,469.1^{\mathrm{b}}$ & -- & -- & -- & -- & 250 & -- & -- \\
\hline DL02 & -- & $1,465.5^{\mathrm{b}}$ & -- & -- & -- & -- & 290 & -- & -- \\
\hline K-1 & -- & $1,493.68$ & -- & -- & -- & -- & -- & -- & -- \\
\hline OW-9 & -- & $1,536.06$ & -- & -- & -- & -- & -- & -- & -- \\
\hline OW-12 & -- & $1,535.96$ & -- & -- & -- & -- & -- & -- & -- \\
\hline OW-14 & -- & $1,533.49$ & -- & -- & -- & -- & -- & -- & -- \\
\hline OW-15 & -- & $1,531.81$ & -- & -- & -- & -- & 28 & -- & -- \\
\hline OW-20 & -- & $1,539.93$ & -- & -- & -- & -- & 55 & -- & -- \\
\hline RW-1 & -- & $1,507.37$ & -- & -- & -- & -- & -- & -- & -- \\
\hline
\end{tabular}

${ }^{a}$ Logs were collected in open boreholes, many of which were later reconstructed with one or more screens and renamed with a suffix to indicate shallow (S), intermediate(I) or deep (D) as listed in table 3.

bIndicates altitude of land surface estimated from light detection and ranging (lidar) digital elevation data; if no footnote, altitude from survey. 


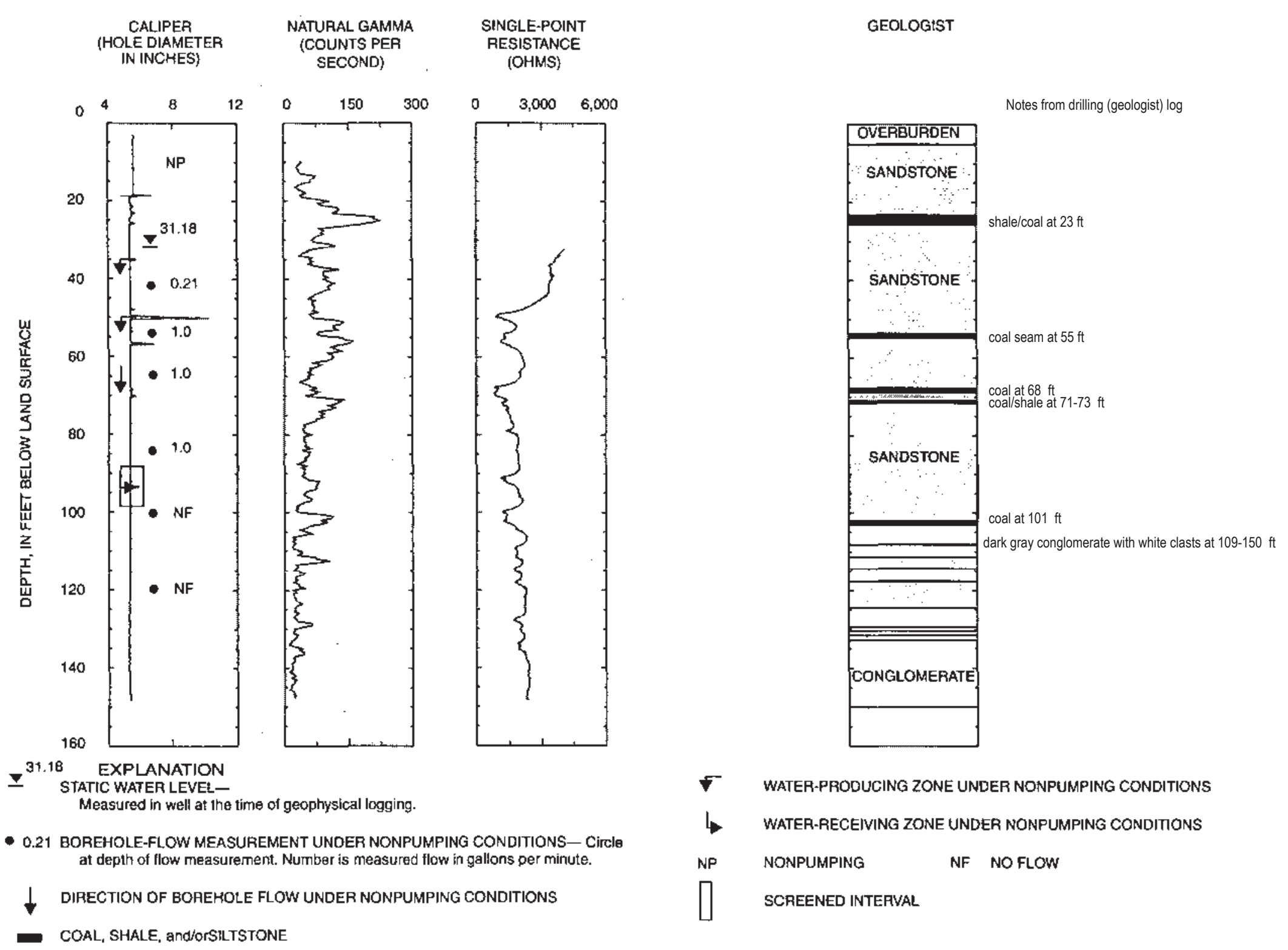

Figure 8. Geophysical logs with notes about lithology from geologist logs and interpreted water-bearing zones for open borehole MW-12D (USGS well LU-765) and intervals selected for screening when the well was constructed as well MW-12D, Valmont TCE Superfund Site, Luzerne County, Pennsylvania. Figure modified from Tetra Tech NUS, Inc. (2004b). ft, feet. 
Coal and, to a lesser extent, impure or bony coal (carbonaceous shale) can be identified by its relatively low density (less than $2.4 \mathrm{~g} / \mathrm{cm}^{3}$ ) (Wood and others, 1983) compared to the density for other lithologies (2.6 to $2.8 \mathrm{~g} / \mathrm{cm}^{3}$ ) for the Site logs, with the increasing carbon-content of the coal estimated to be related to decreasing density on borehole density logs, and its appearance (black) on OTV and video logs. Several coal beds are at or near log depths where relatively elevated gamma activity and low resistivity occur, a geophysical log pattern that could be associated with carbonaceous shale or bony coal rather than anthracite. In a brief survey of radioactivity in the anthracite region of eastern Pennsylvania, greater radioactivity generally was reported for sections of carbonaceous shale than for anthracite in the Pottsville Formation (Welsh, 1953).

Examples of geophysical logs and interpreted corresponding lithology are shown for boreholes with OTV logs (E-1, E-2, E-3, E-4, E-5, E-6, MW-28, and MW-29) in appendix 1 (figs. 1.1-1.7, 1.21). In these boreholes, sandstone most commonly is present nearest the land surface, with shale, more sandstone, and conglomerate present at greater depths. Sandstone ranges from fine to coarse grained. Clasts in the conglomerate units range in size, with some layers having large white (likely quartz) clasts (estimated to be 0.5 to 1 inch in diameter) (fig. 9C). Coal, bony coal, and (or) carbonaceous shale layers appear black on the OTV logs (see appendix 1, figs. 1.1-1.7, 1.21). Seams of anthracite coal appear black and shiny on the video logs (fig. 9E).

Natural gamma and single-point resistance logs for several boreholes with OTV logs, including E-1, E-3, E-4, and MW-28 (appendix 1, figures 1.1, 1.3, 1.4, and 1.7), indicate a common distinctive pattern of two fining upward sequences capped by thin coal and (or) bony coal layers identified by density logs, with the two coals separated by about 20 to $24 \mathrm{ft}$ in depth on each of the logs. For example, the shallower of the two fining upward sequences indicated by natural gamma and density logs for borehole E-3 is capped by a coal at about $57 \mathrm{ft}$ bls and the deeper fining upward sequence is capped by a coal or bony coal at about $78 \mathrm{ft}$ bls (fig. 10), and comparison of logs for borehole E-3 and E-4 shows that the shallower of these two fining upward sequences are capped by a coal at similar depths of about 57 and $60 \mathrm{ft}$ bls, respectively (fig. 11A and 11B). Density logs for E-4 and the eight other boreholes with density logs (table 1) are shown in the report by Tetra Tech NUS, Inc. (2010). Other boreholes without OTV logs that appear to penetrate these two distinctive fining-upward sequences possibly include E-7, E-9, E-11, and MW-12D, as shown in log figures reported by Tetra Tech NUS, Inc. (2011, 2014). The logs for E-11 show several intervals of relatively elevated natural gamma activity, with the shallowest fining upward sequence ending at about $76 \mathrm{ft}$ bls (appendix 1, fig. 1.9).

The contact between the conglomerates and sandstones of the Pottsville Formation and the siltstones/shales of underlying Mauch Chunk Formation is indicated by an increase in natural gamma activity measured at depths from about 200 to
$250 \mathrm{ft}$ bls in logs for the deepest boreholes (MW-7, MW-19D, MW-22, and MW-27, which range from 249 to $400 \mathrm{ft}$ in depth) at and near the Valmont TCE Superfund Site (appendix B-1 in Tetra Tech NUS, Inc., 2004b). Geologist (driller's) logs for MW-19D indicate that the higher natural gamma activity at these depths is associated with siltstone and shale (appendix 1, fig. 1.19). Elevated natural radioactivity is reported to be present in rocks at the Pottsville/Mauch Chunk contact about $16 \mathrm{mi}$ (20 kilometers) to the southeast of the Valmont TCE Superfund Site (Sevon and others, 1978), but the source of the apparent relatively elevated radioactivity associated with the Pottsville/Mauch Chunk contact as indicated by natural gamma logs for wells at the Site is not known.

\section{Geophysical Logs and Geologic Structure}

Using geophysical logs collected in 2009 , the orientation of bedding and fracture planes in nine individual boreholes (E-1, E-2, E-3, E-4, E-5, E-6, MW-2I, MW-28D, and MW-29) was previously determined (Tetra Tech NUS, Inc., 2010). Except for boreholes MW-2I and E-5 in the western part of the study area, where a possible fault intersecting borehole E-5 was identified, the mean strike and dip of bedding was estimated to be N. $87^{\circ}$ E. and $15^{\circ} \mathrm{SE}$., respectively (Tetra Tech NUS, Inc., 2010). This finding is generally consistent with lithologic correlations between boreholes done for this study and discussed in the section "Lithologic Correlations and Cross Sections." Correlation of distinctive fining upward sequences identified from geophysical logs for numerous boreholes (E-3, E-4, E-1, E-11, and MW-28) near the center and to the northeast of the former Chromatex Plant indicate that the beds strike east-northeast and dip to the southeast in that area, in agreement with the reported bedding orientation (Tetra Tech NUS, Inc., 2010). The estimated altitude (in feet above NAVD 88) of the shallower of the two fining upward sequences in selected wells is shown by the purple values listed at boreholes and in the dashed purple lines interpolated between boreholes in the inset area covering the northern part of the Plant (bounded by the red box) near the center of figure 7; thus, the dashed lines approximately represent equal altitude of this bed, which can be interpreted as strike. The lines of decreasing altitude from 1,490 to $1,475 \mathrm{ft}$ above NAVD 88 (fig. 7), indicate that the bed generally dips to the south in this part of the study area

Video logs also can provide information about bedding orientation, especially at contacts between lithologies or where bedding is disrupted. In most boreholes with video logs (table 1), bedding contacts appear to be low angle, consistent with the reported mean dip of about $15^{\circ}$. However, in the eastern part of the study area, video logs in at least one borehole (MW-15D) and possibly others (MW-11D and MW-14D) provide evidence of steeply dipping beds and (or) faulting at some depths, including an intensely fractured zone near $63 \mathrm{ft}$ bls in borehole MW-15D that is likely at a fault and another at about $38 \mathrm{ft}$ bls in borehole MW-14D (figs. 12 and 13). 


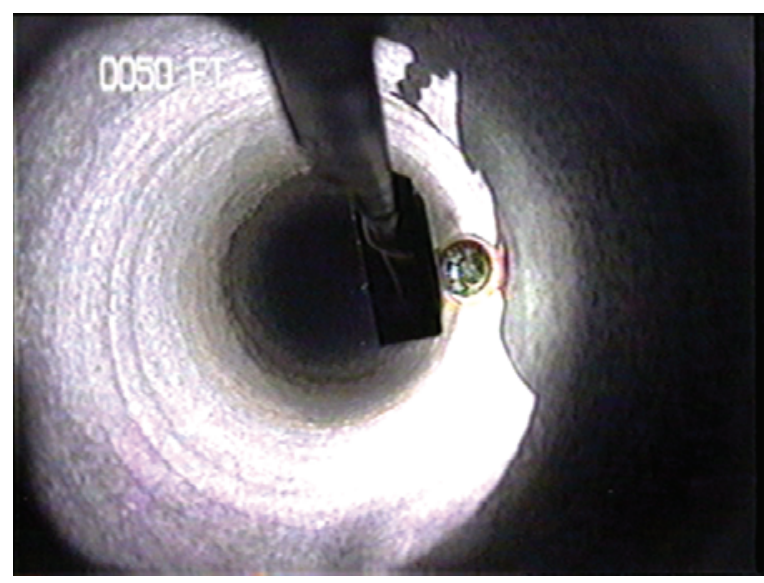

A. MW-19D at 50 feet below land surface (ft bls)

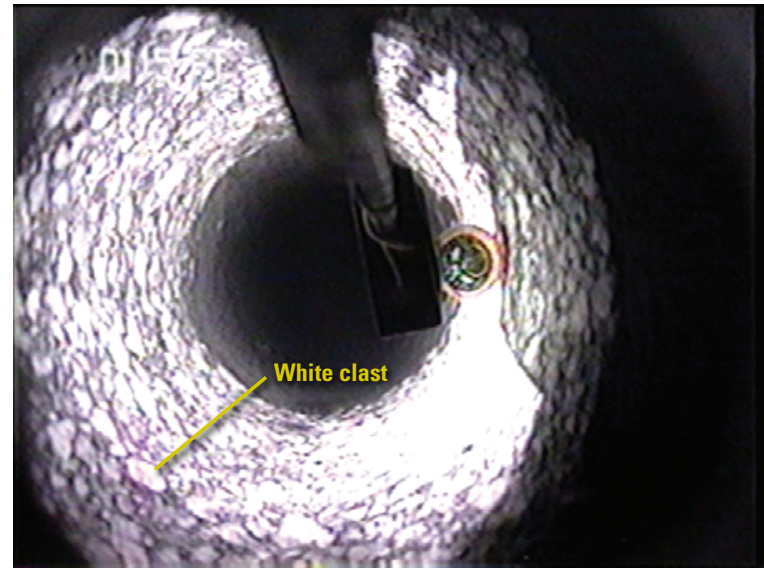

C. MW-19D at $115 \mathrm{ft}$ bls

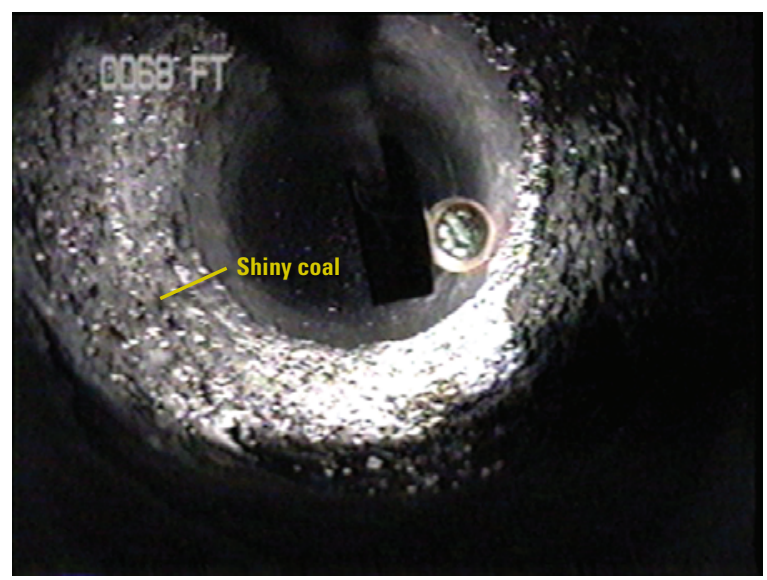

E. MW-12D at $68 \mathrm{ft}$ bls

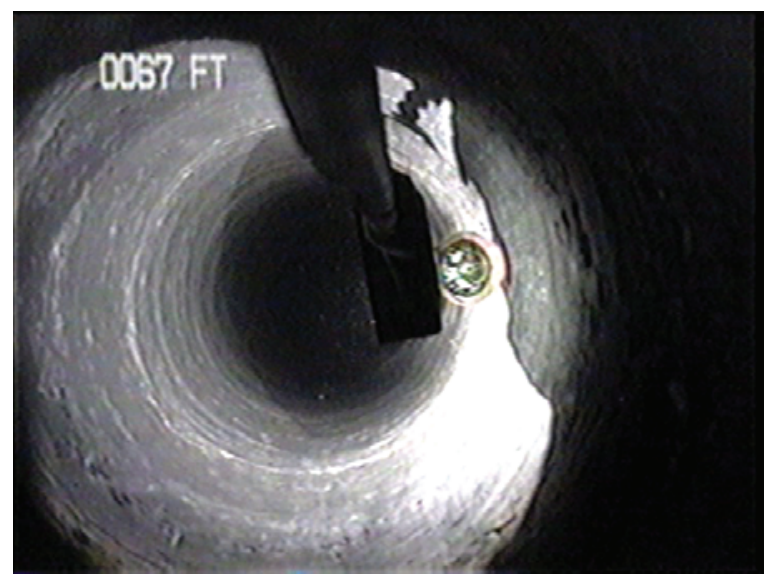

B. MW-19D at $67 \mathrm{ft}$ bls

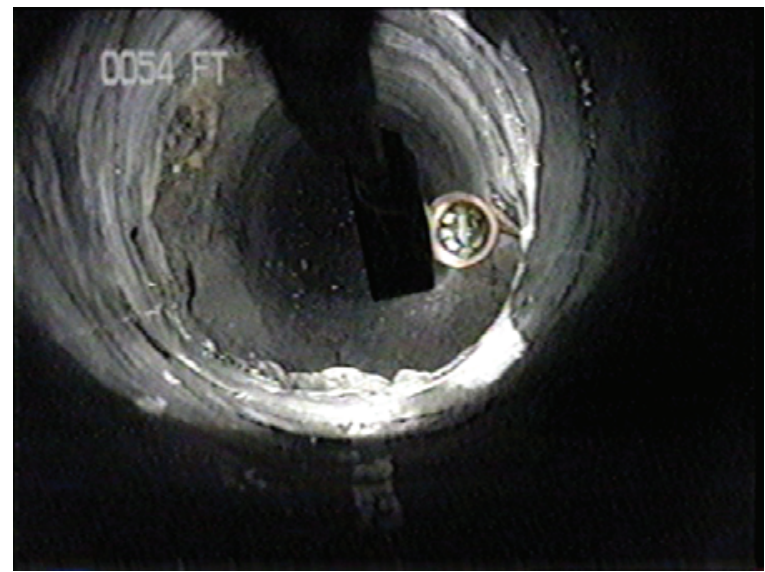

D. MW-12D at $54 \mathrm{ft} \mathrm{bls}$

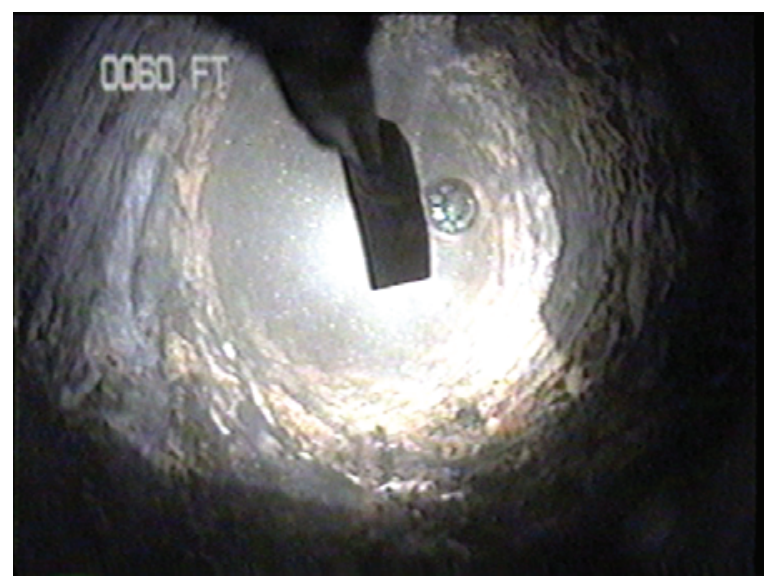

F. MW-11D at $60 \mathrm{ft}$ bls

Figure 9. Still images of video logs showing different lithologies including $A$, light medium-grained sandstone at about 50 feet ( $\mathrm{ft}$ ) below land surface (bls) in borehole MW-19D, $B$, dark fine-grained sandstone at about $67 \mathrm{ft}$ bls in borehole MW19D, C, coarse conglomerate at about $115 \mathrm{ft}$ bls in borehole MW-19D, D, shale at about $54 \mathrm{ft}$ bls in borehole MW-12D, $E$, coal seen as shiny layer at about $68 \mathrm{ft}$ bls in borehole MW-12D, and $F$, possible bony coal at about $60 \mathrm{ft}$ bls in borehole MW-11D, Valmont TCE Superfund Site, Luzerne County, Pennsylvania. 


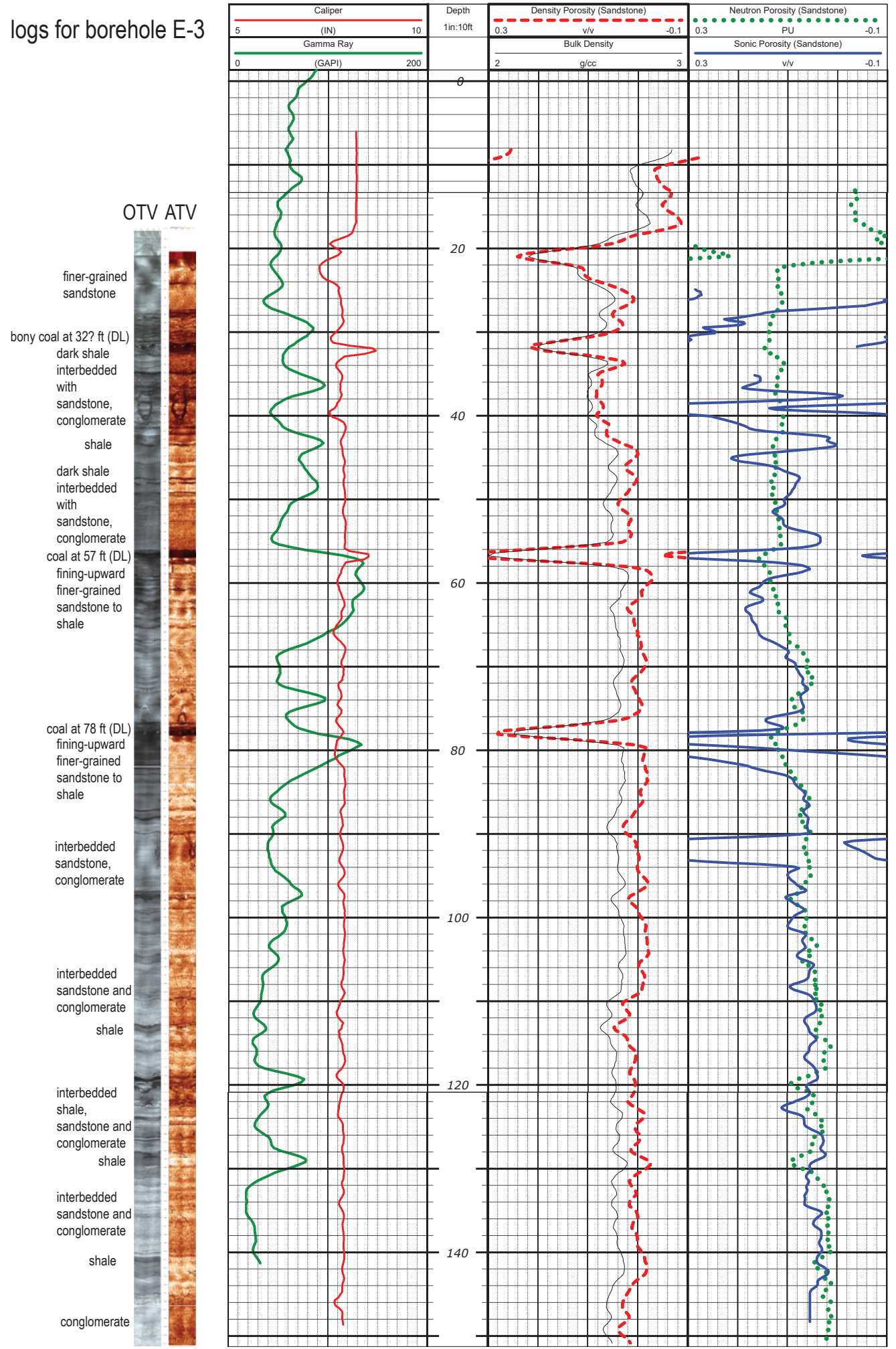

Figure 10. Natural gamma, density, porosity, and optical (OTV) and acoustic (ATV) televiewer logs for open borehole E-3, annotated with comments about lithology from review of OTV logs, Valmont TCE Superfund Site, Luzerne County, Pennsylvania. Coal or bony coal/carbonaceous shale is indicated by a lower density on the density log (DL). The natural gamma log is shaded to indicate the relative magnitude from lower (yellow) to higher (green). Geophysical logs and log figures from Tetra Tech NUS, Inc. (2010). ft, feet; in, inches; GAPI, American Petroleum Institute unit for gamma log;" v/v, volume per volume; g/cc, grams per cubic centimeter; PU, porosity unit. 


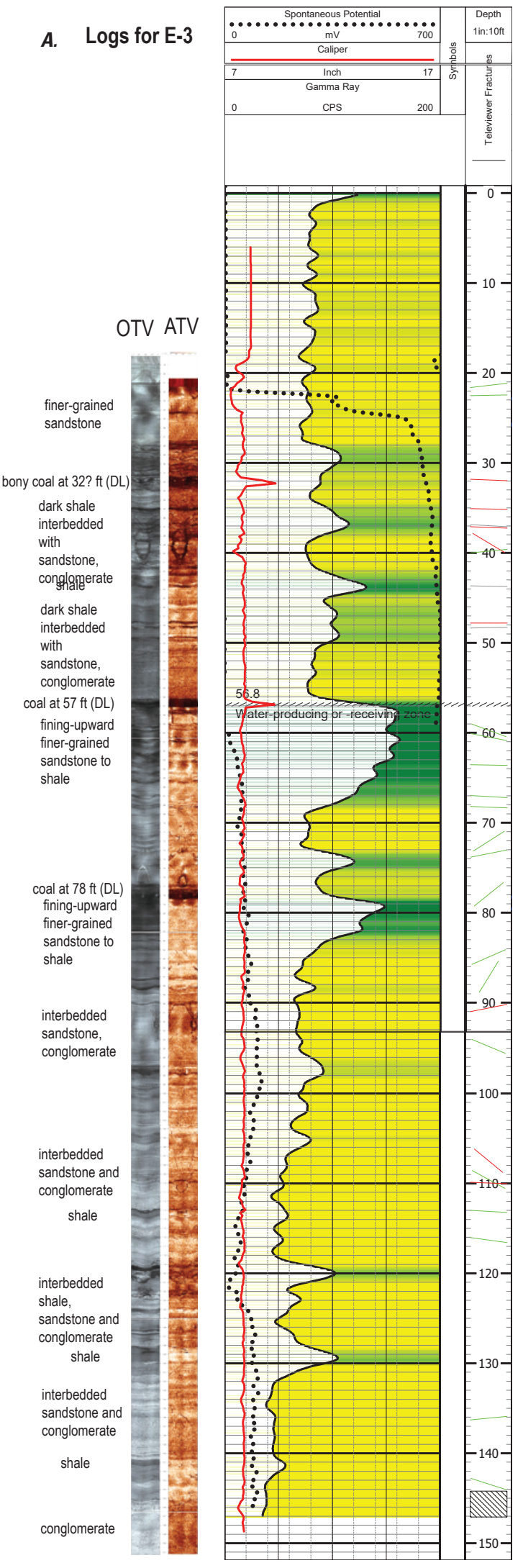

Figure 11. Natural gamma and caliper logs for open boreholes $A, \mathrm{E}-3$ and $B, \mathrm{E}-4$ from Tetra Tech NUS, Inc. (2010), annotated with comments about lithology from review of optical televiewer (OTV) logs, Valmont TCE Superfund Site, Luzerne County, Pennsylvania. Fining upward sequences (indicated by increasing natural gamma activity, shaded yellow to green) capped by coal or bony coal, with water-bearing fractures near lithologic contacts, are indicated by logs at depths of about 57 feet below land surface (ft bls) in borehole E-3 and $60 \mathrm{ft}$ bls in borehole E-4. Coal or bony coal/carbonaceous shale also indicated by lower density on density log (DL). Geophysical logs and log figures, including depicted/ interpreted water-bearing zones, from Tetra Tech NUS, Inc. (2010). Additional logs for boreholes E-3 and $\mathrm{E}-4$ are shown in appendix 1 , figure 1.3 and 1.4. ATV, acoustic televiewer log; mV, millivolts; CPS, counts per second; in, inch; $\mathrm{ft}$, feet; ?, indicates uncertainty in identification of feature. 


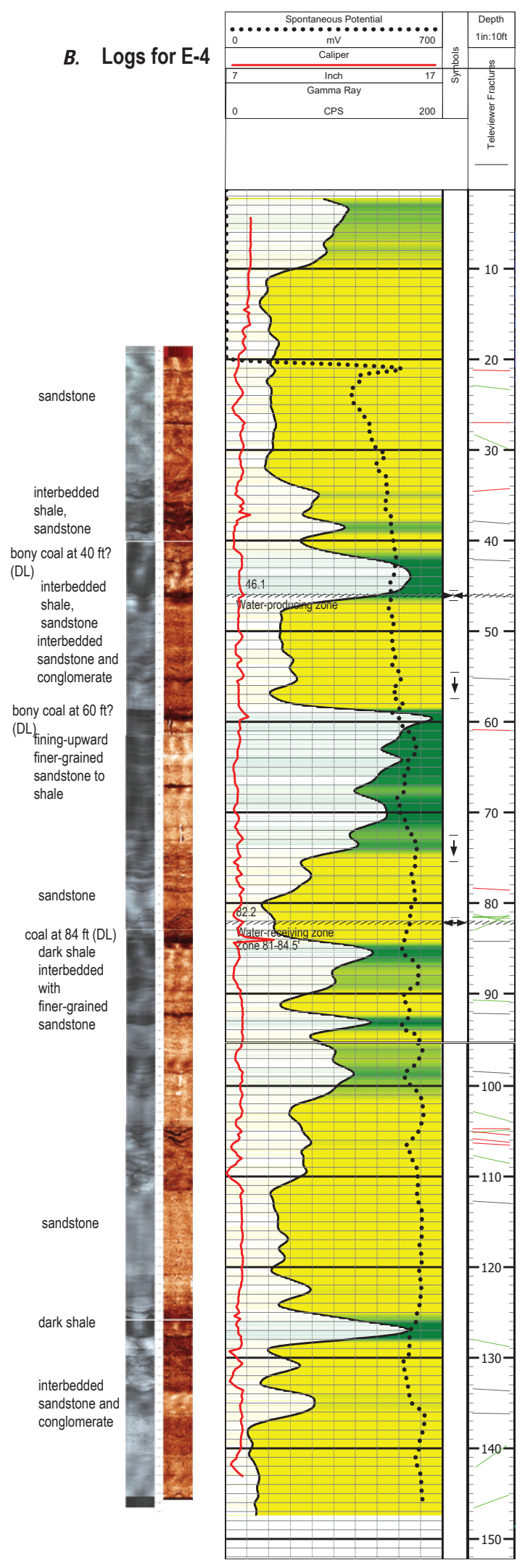

Figure 11.-Continued 


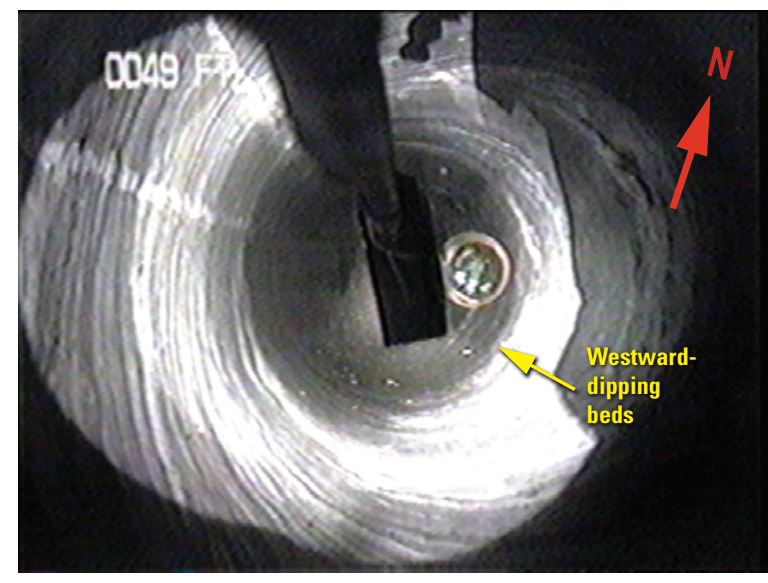

A. MW-15D at 49 feet below land surface (ft bls)

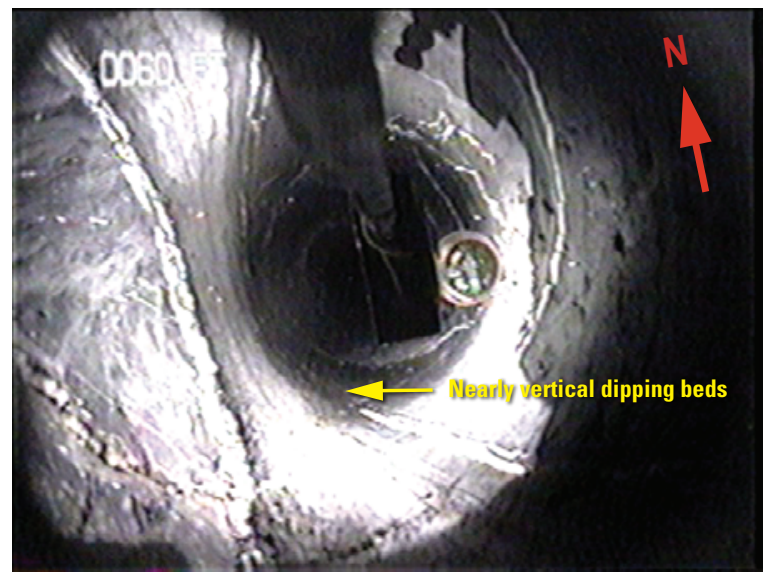

C. MW-15D at $60 \mathrm{ft}$ bls

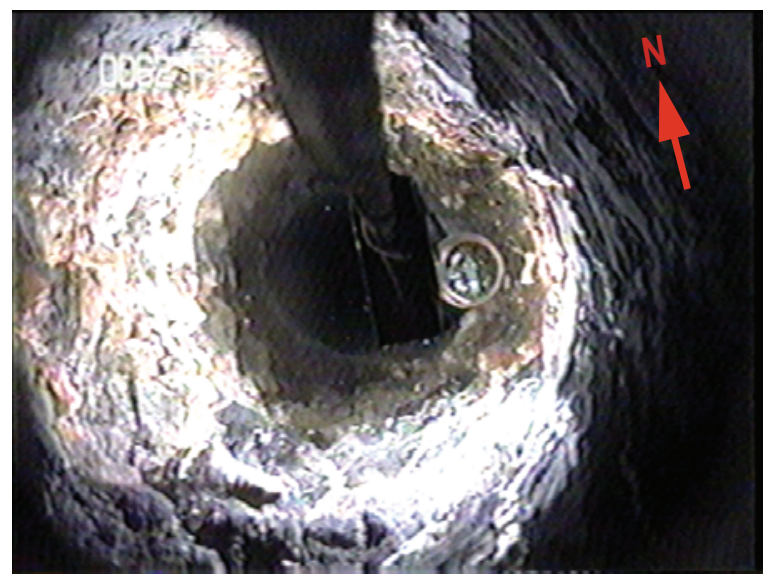

E. MW-15D at $62.5 \mathrm{ft}$ bls

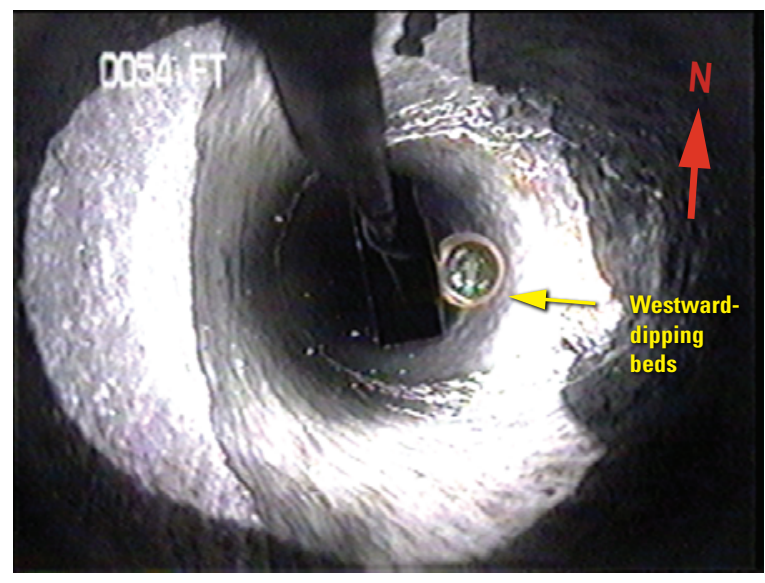

B. MW-15D at $54 \mathrm{ft} \mathrm{bls}$

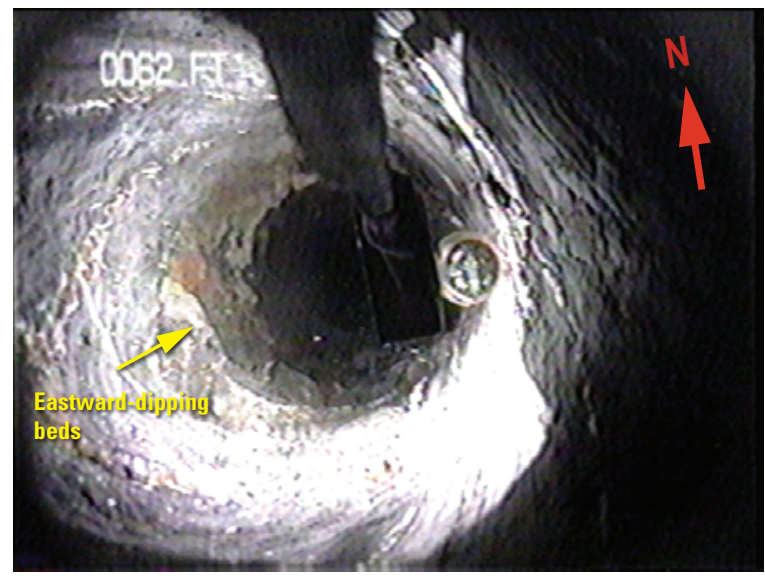

D. MW-15D at $62 \mathrm{ft} \mathrm{bls}$

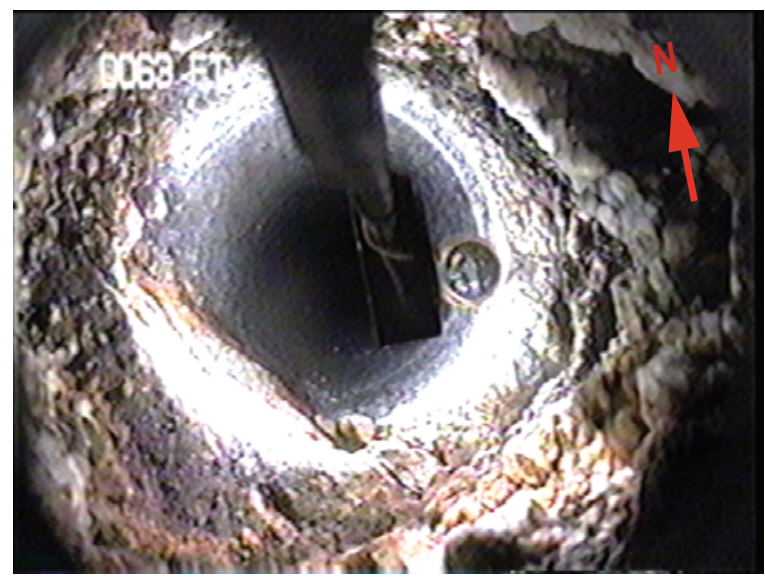

F. MW-15D at $63 \mathrm{ft} \mathrm{bls}$

Figure 12. Still images from borehole video log showing changes in bedding orientation and possibly structural features in open borehole MW-15D including $A$, westward-dipping beds at about 49 feet (ft) below land surface (bls), $B$, westward-dipping beds at about $54 \mathrm{ft}$ bls, $C$, nearly vertical beds at about $60 \mathrm{ft}$ bls, $D$, eastward-dipping beds at about $62 \mathrm{ft}$ bls, $E$, an intensely fractured zone at about $62.5 \mathrm{ft} \mathrm{bls,} \mathrm{and} F$, the base of the intensely fractured zone and contact with underlying competent sandstone at about $63 \mathrm{ft}$ bls, Valmont TCE Superfund Site, Luzerne County, Pennsylvania. 


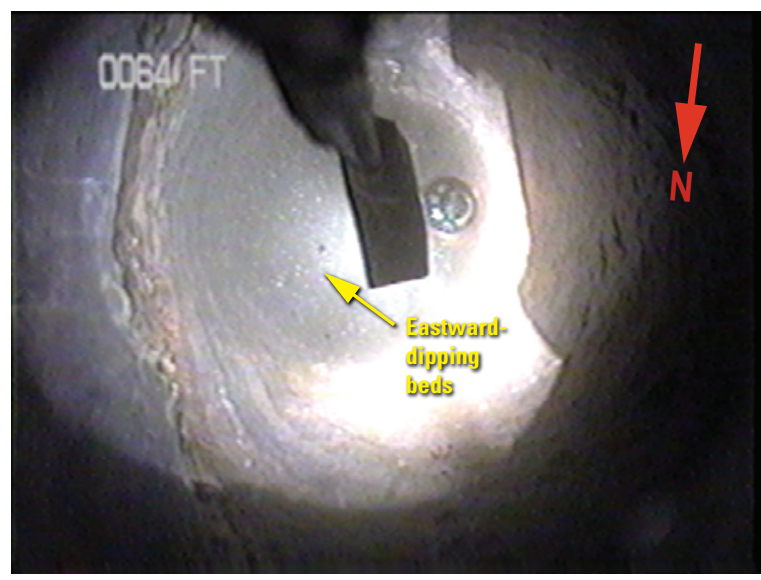

A. MW-11D at 64 feet below land surface (ft bls)

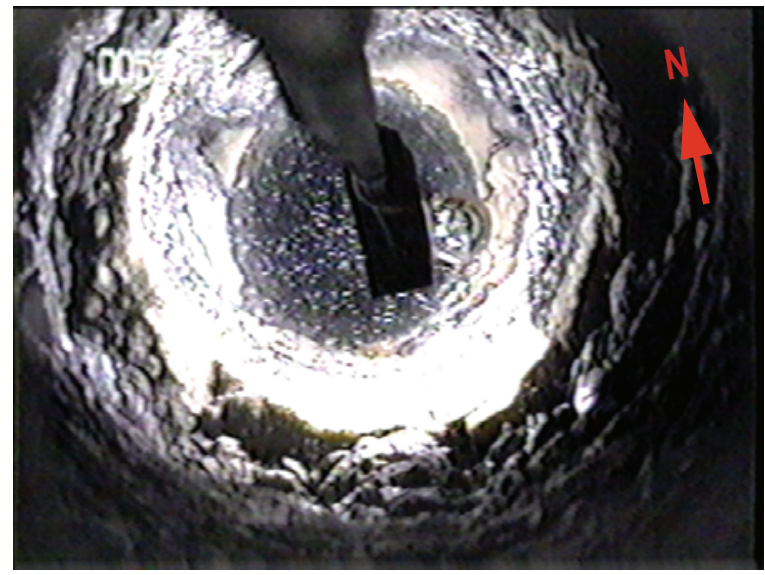

C. MW-21D at $56 \mathrm{ft}$ bls

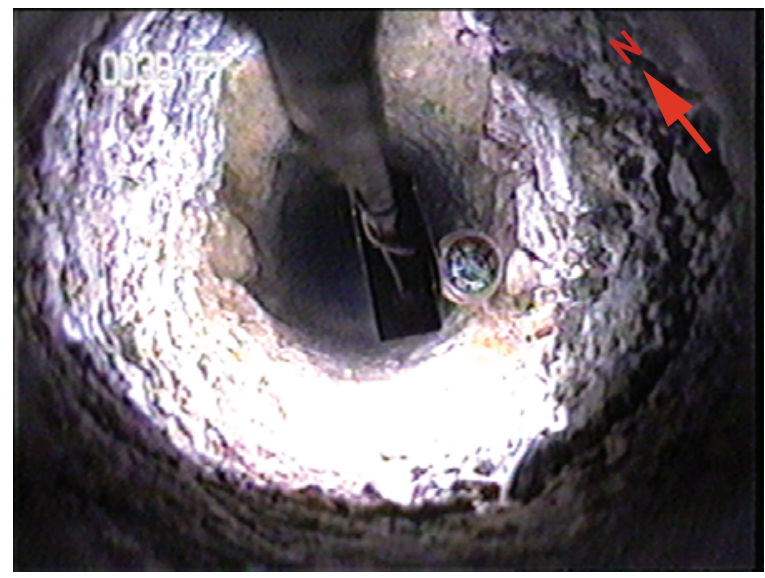

E. MW-14D at $38 \mathrm{ft}$ bls

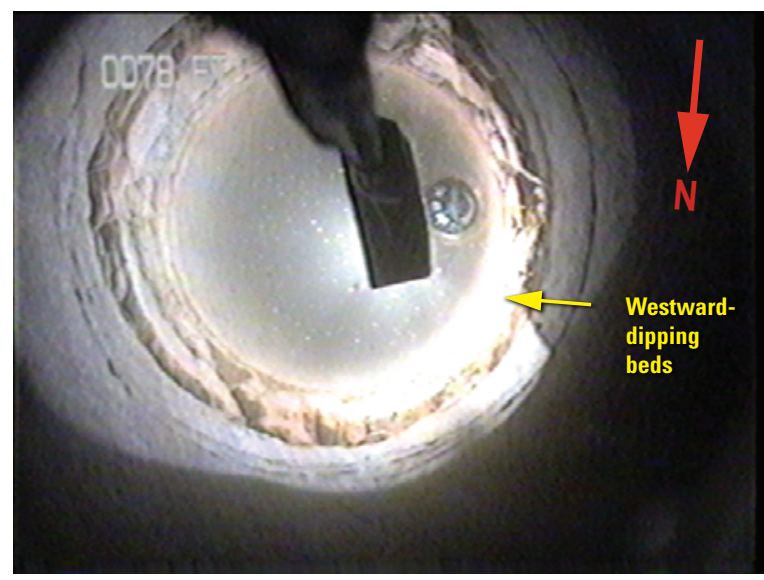

B. MW-11D at $78 \mathrm{ft} \mathrm{bls}$

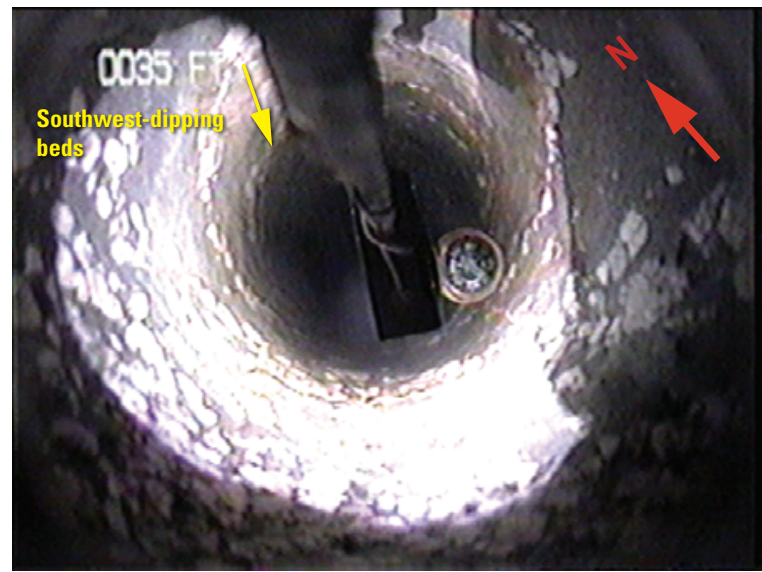

D. $M W-14 D$ at $35 \mathrm{ft}$ bls

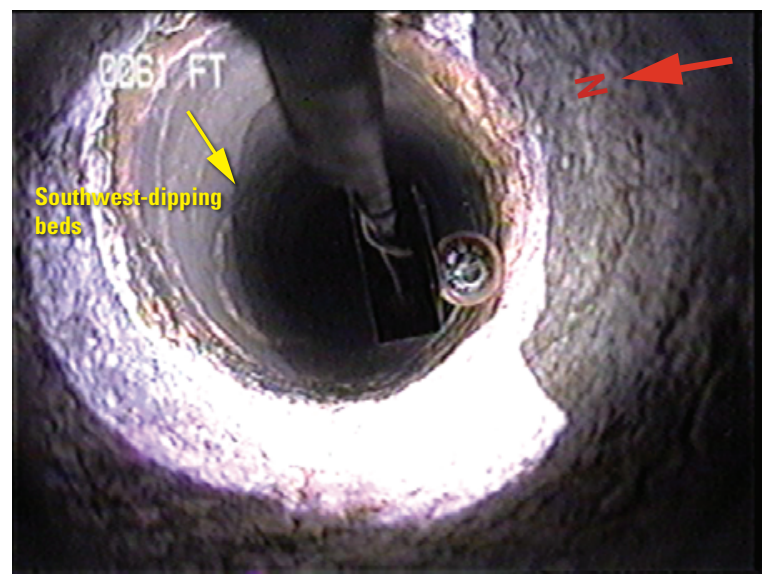

F. MW-14D at $61 \mathrm{ft}$ bls

Figure 13. Still images of video logs showing changes in bedding orientation and possibly structural features including $A$, eastward dipping beds at about 64 feet $(\mathrm{ft}$ ) below land surface (bls) in borehole MW-11D, $B$, nearly horizontal fractures in dipping sandstone at about $78 \mathrm{ft}$ bls in borehole MW-11D, $C$, an intensely fractured zone at about $56 \mathrm{ft}$ bls in borehole MW-21D, D, southwest dipping conglomerate beds at about $35 \mathrm{ft}$ bls in borehole MW-14D, E, a fractured zone at about $38 \mathrm{ft}$ bls in borehole MW-14D, and $F$, a southwest-dipping bedding contact between sandstone and shale at about $61 \mathrm{ft}$ bls in borehole MW-14D, Valmont TCE Superfund Site, Luzerne County, Pennsylvania. 


\section{Geophysical Logs and Water-Bearing Zones}

The principal water-bearing zones in geologic units underlying the Site, as identified during geophysical logging (Tetra Tech NUS, Inc., 2004b, 2010, 2011, 2014, 2016), are associated with fractures and openings that commonly occur at or near the contacts between different lithologies, especially at contacts between finer-grained lithologies such as shale or coal and coarser-grained lithologies such as sandstone or conglomerate. Water-bearing zones as interpreted from the suite of geophysical logs by EPA's contractors, who collected the logs that are shown on plots for selected wells in appendix 1 (figs. 1.1-1.19). Actual water-bearing zones may differ from estimated locations shown on log plots, as these initial interpretations were based on geophysical logs only without confirmation from other hydraulic tests or video logs and limited by available borehole flow data.

Openings at the contact between lithologies can be large, as shown just below the depths of about 48 and $67 \mathrm{ft}$ bls in video logs of boreholes MW-12D and MW-15D, respectively, where openings as much as $1 \mathrm{ft}$ in vertical depth occur below the contact between coarse sandstone/conglomerate and underlying shale (fig. 14A, C). The opening near $48 \mathrm{ft}$ bls in borehole MW-12D was identified as a primary water-bearing zone from a suite of geophysical logs (fig. 8). The opening near $67 \mathrm{ft}$ bls in borehole MW-15D also was identified as a water-bearing zone from a suite of geophysical logs (appendix 1, fig. 1.17). Coal beds are present near water-bearing openings at some of these contacts between lithologies (appendix 1, fig. 1.1-1.7), as can be seen at depths of about $47 \mathrm{ft} \mathrm{bls}$ in borehole MW-16D (fig. 15C, $27 \mathrm{ft}$ bls in borehole MW-6 (fig. 15D), and $81 \mathrm{ft}$ bls in borehole MW-13D (fig. 15E).

A few water-bearing fractures occur within sandstone or conglomerate units or at contacts between sandstone and conglomerate. Many to most water-bearing fractures and openings generally appear approximately parallel to bedding, as indicated by video logs and review of log data in Tetra Tech NUS, Inc. (2010). Some water-bearing zones are associated with what appear to be fault contacts or structurally disrupted beds (fig. 12 for borehole MW-15D). Other examples of large water-bearing openings associated with highly fractured zones include openings near $42 \mathrm{ft}$ bls GW-26 (fig. 15B) and $34 \mathrm{ft}$ bls in borehole and MW-17 (fig. 15F); these types of large openings were not common in the available video logs of boreholes.

Following geophysical logging, most open boreholes were reconstructed later (less than a month to several years after logging) as monitoring wells with 10 - to 20 - $\mathrm{ft}$ screens spanning water-producing fractures (Tetra Tech NUS, Inc., 2004a,b; 2016). As part of the data evaluation for this report, USGS review of the zones selected for reconstruction indicates that most screens span aquifer intervals that include fractures at or near the contact between sandstone and shale lithologies. Information about the relative productivity of some water-bearing zones was collected as part of aquiferinterval-isolation (packer) testing in 14 open boreholes (E-1 through E-14) drilled at the Valmont TCE Superfund Site (Tetra Tech NUS, Inc., 2016), but the results should be interpreted with caution as the current (2021) USGS review of field data for these tests indicates apparent error or uncertainty in the calculation of specific capacity for some isolated intervals related to computation errors (especially for the shallowest intervals of some wells owing to the use of drawdown in the interval below the pumped zone rather than in the pumped zone), unstable baseline water level prior to pumping, or large drawdown in intervals adjacent to the pumped interval. The specific capacities of water-bearing zones as calculated using pumping rates and drawdown measured in the pumped intervals isolated by packers previously were reported to range from 0.0025 to 1.71 gallons per minute per foot of drawdown ([gal/min $] / \mathrm{ft})$, with specific capacity in the shallowest intervals greater than 1 (gal/min)/ft in three wells (E-3, E-4, and E-6) (Tetra Tech NUS, Inc., 2016) (appendix 2, table 2.1). Using packer test field notes (Tetra Tech NUS, Inc., 2016), revised specific capacity values - corrected where possible by USGS for this report-are listed with previously reported values in appendix 2 (table 2.1). Revised specific capacities for the shallowest intervals of four wells (E-3, E-4, E-6, and E-9) range from about 0.2 to $0.4(\mathrm{gal} / \mathrm{min}) / \mathrm{ft}$, lower than previously reported values ranging from 0.77 to $1.71(\mathrm{gal} / \mathrm{min}) / \mathrm{ft}$ for these wells (Tetra Tech NUS, Inc., 2016). For intervals in some other wells, reported specific capacities (Tetra Tech NUS, Inc., 2016) likely are higher than actual, as drawdowns were affected (reduced) by interconnection with adjacent intervals or were calculated using elevated pre-pumping water levels that had not equilibrated. The specific capacities for the two isolated intervals, $20-40 \mathrm{ft}$ and $45-65 \mathrm{ft}$, in borehole E-5 were among the highest reported for tested intervals, 0.622 and $1.097(\mathrm{gal} / \mathrm{min}) / \mathrm{ft}$, respectively (Tetra Tech NUS, Inc., 2016), but likely are higher than actual because drawdowns in isolated and adjacent intervals indicate apparent interconnections related to an incomplete packer seal or fracture connections outside the borehole. The apparent interconnection between the isolated intervals at 20-40 ft bls and 45-65 ft bls in borehole E-5 may be related to a possible fault that was noted at a depth of about $49 \mathrm{ft}$ bls in the geophysical log report for E-5 (Tetra Tech NUS, Inc., 2010). Overall, given the limitations of the packer test data, the results generally indicate that the relatively shallow zones ( 20 to $60 \mathrm{ft}$ bls) had modest but higher specific capacity than the deeper zones (60 to $120 \mathrm{ft}$ bls) tested. Assuming that specific capacity values less than 0.001 (gal/min)/ft could not be measured (ND) and by grouping tests by midpoint depths of intervals tested, the median specific capacity values for the relatively shallow ( 20 to $<60 \mathrm{ft}$ bls) and deeper ( 60 to $120 \mathrm{ft}$ bls) intervals were about 0.107 and $<0.001$ (gal $/ \mathrm{min}) / \mathrm{ft}$, respectively (appendix table 2.1). The data indicate that the highest specific capacity values were measured in intervals less than $50 \mathrm{ft}$ bls. At depths greater than $60 \mathrm{ft}$ bls, only 7 of 18 intervals tested apparently had specific capacity values that were high enough to be measured, with the highest measured specific capacity of $0.11(\mathrm{gal} / \mathrm{min}) / \mathrm{ft}$ in the $62-76 \mathrm{ft}$ bls interval in borehole E-13. 


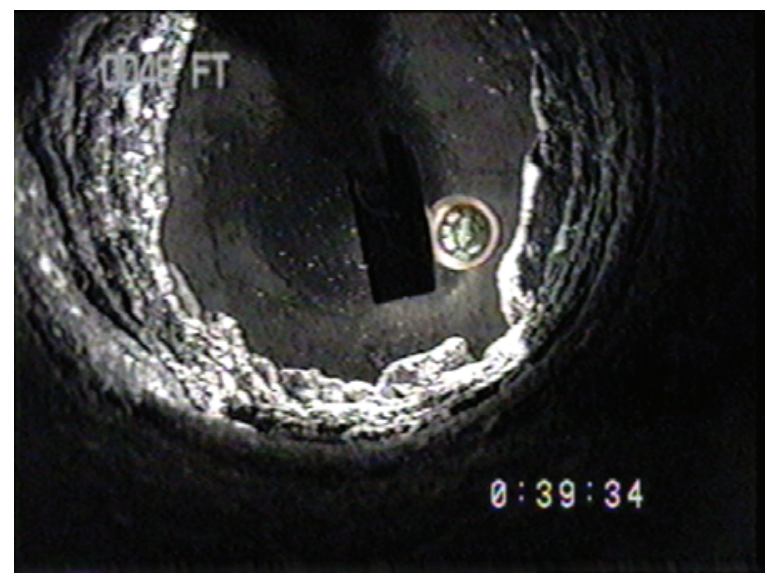

A. MW-12D at 48 feet below land surface (ft bls)

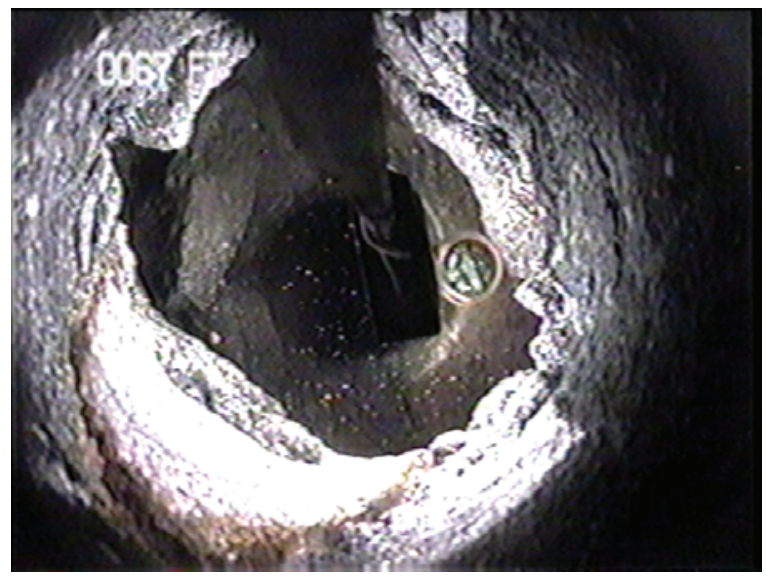

C. MW-15D at $67 \mathrm{ft} \mathrm{bls}$

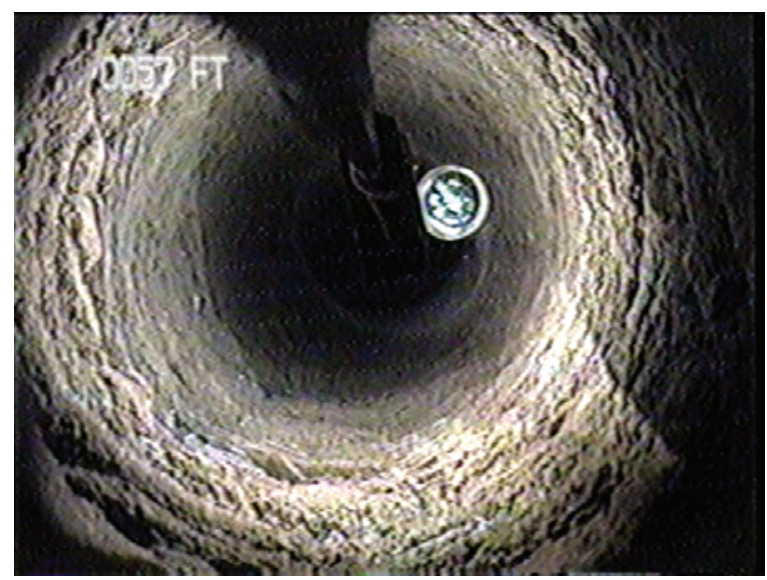

E. MW-22D at $57 \mathrm{ft} \mathrm{bls}$

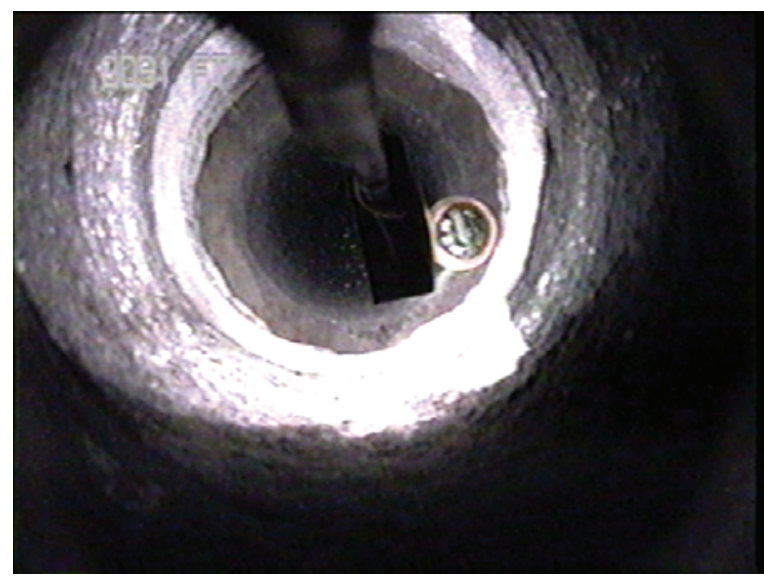

B. MW-12D at $91.5 \mathrm{ft}$ bls

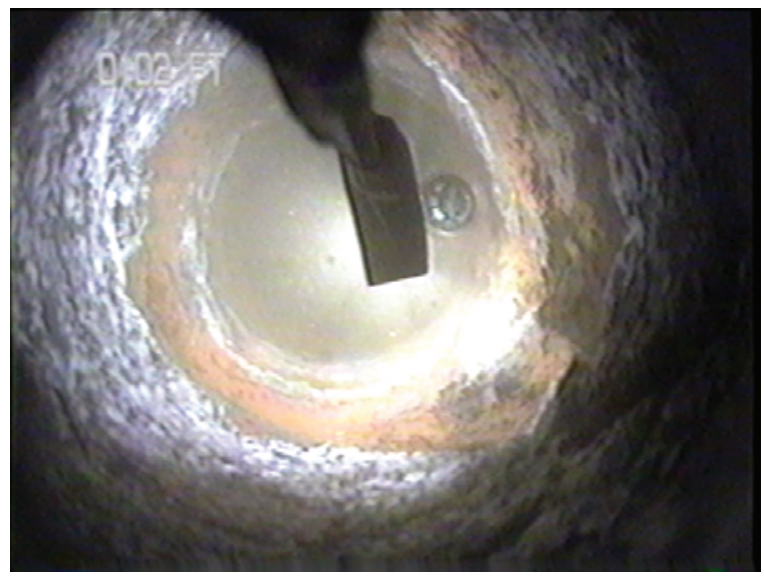

D. MW-11D at $103 \mathrm{ft} \mathrm{bls}$

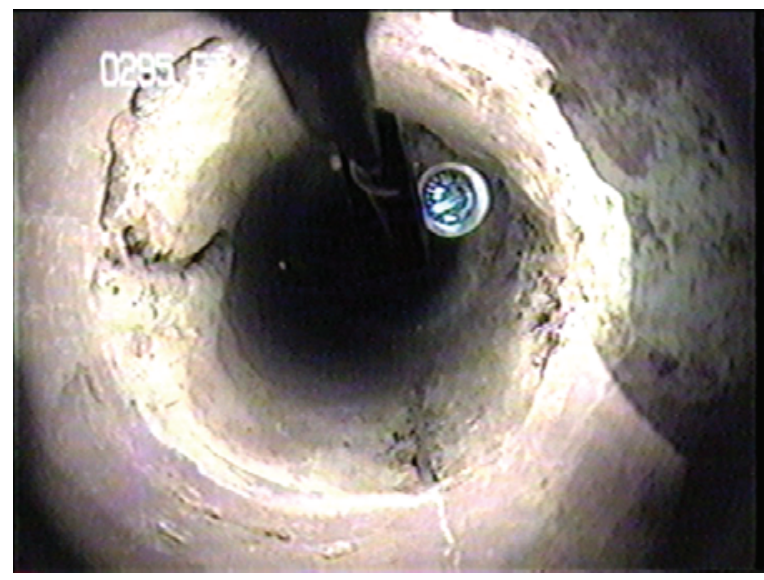

F. MW-22D at $295 \mathrm{ft}$ bls

Figure 14. Still images of video logs showing water-bearing openings including $A$, at a contact between conglomerate and underlying shale at about 48 feet (ft) below land surface (bls) in borehole MW-12D, $B$, at a lithologic contact at about $91.5 \mathrm{ft}$ bls in borehole MW-12D, $C$, at a lithologic contact at about $67 \mathrm{ft}$ bls in borehole MW-15D, $D$, in a low-angle opening at a contact between conglomerate and underlying shale at about $103 \mathrm{ft}$ bls in borehole MW-11D, $E$, in shale layers at about $57 \mathrm{ft}$ bls in borehole MW-22D, and $F$, in a light-colored apparently mineralized zone within reddish Mauch Chunk Formation sandstone at about $295 \mathrm{ft}$ bls in borehole MW-22D, Valmont TCE Superfund Site, Luzerne County, Pennsylvania. 


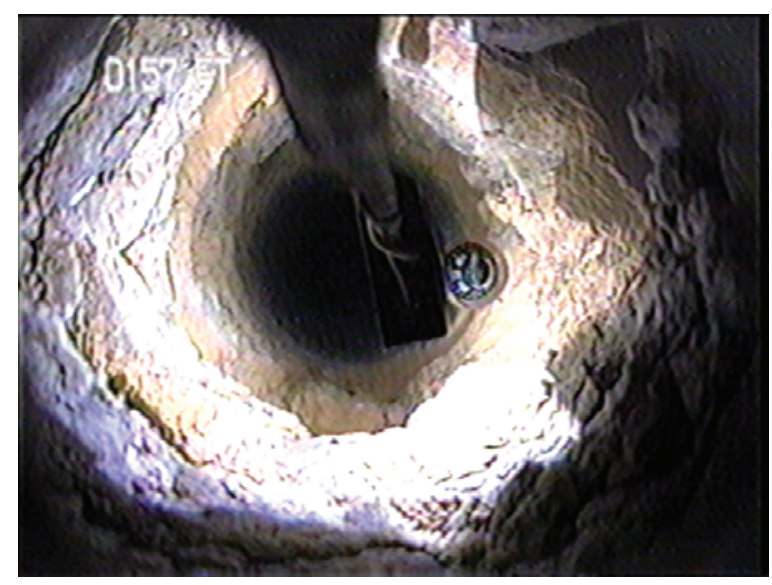

A. MW-14D at 157 feet below land surface (ft bls)

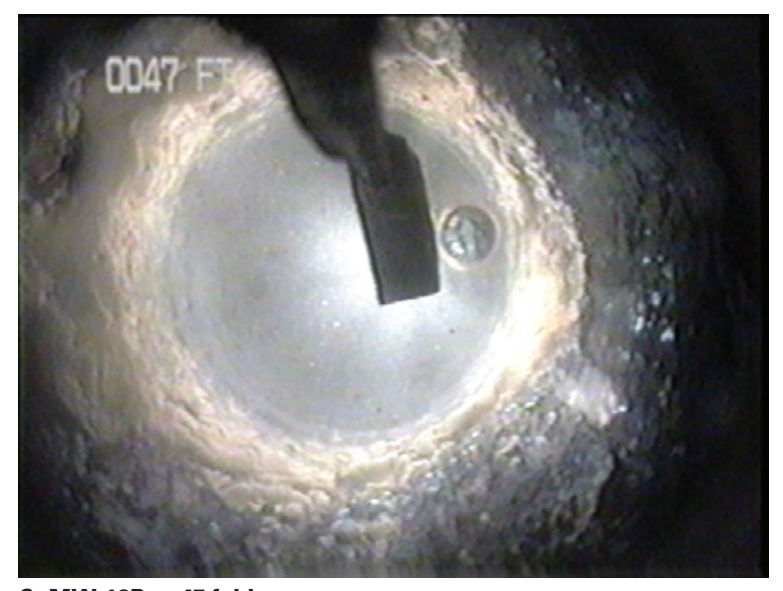

C. MW-16D at $47 \mathrm{ft} \mathrm{bls}$

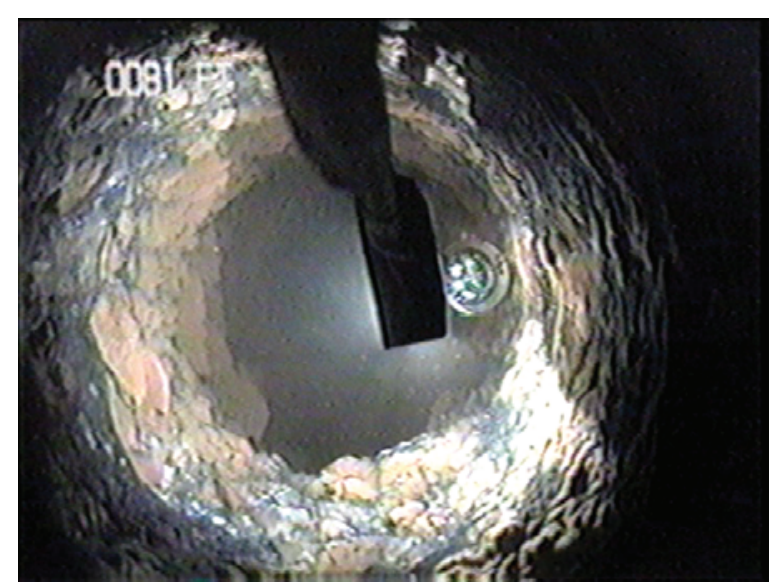

E. MW-13D at $81 \mathrm{ft} \mathrm{bls}$

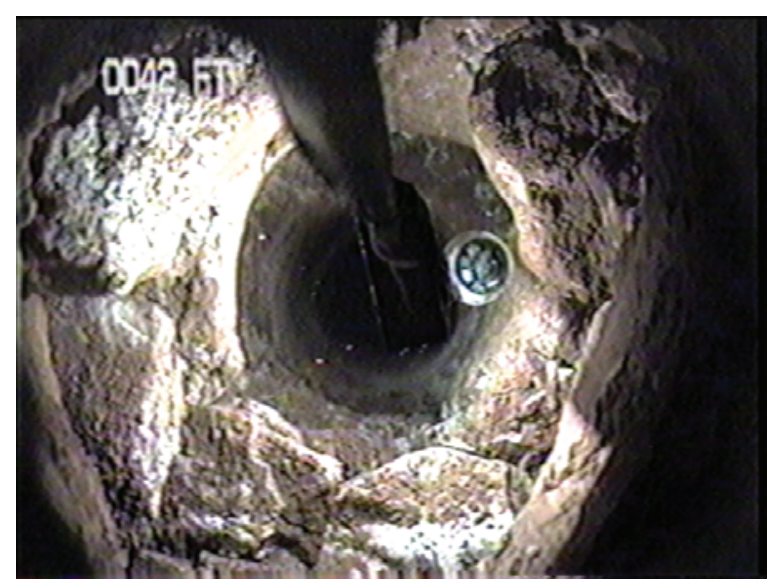

B. GW-26 at $42 \mathrm{ft}$ bls

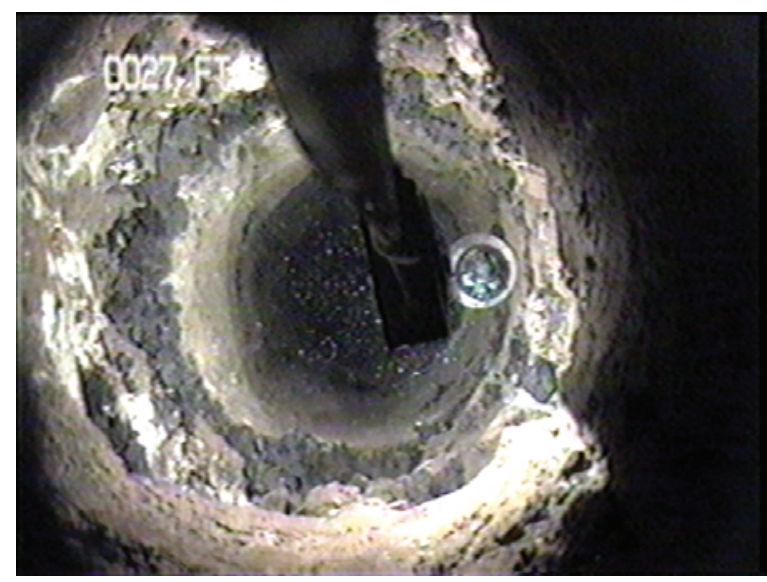

D. MW-6 at $27 \mathrm{ft}$ bls

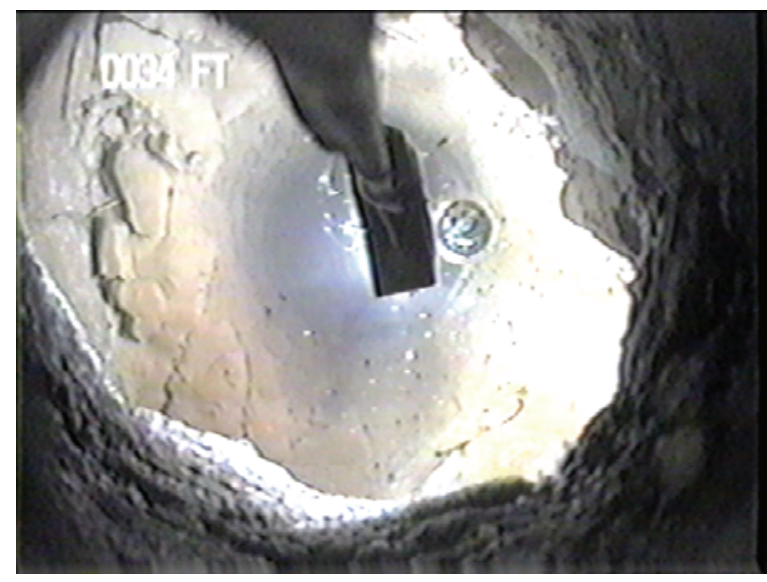

F. MW-17D at $34 \mathrm{ft} \mathrm{bls}$

Figure 15. Still images of video logs showing water-bearing openings including $A$, at lithologic contact at about 157 feet ( $\mathrm{ft}$ ) below land surface (bls) in borehole MW-14D feet, $B$, a rough broken opening above the contact near $42 \mathrm{ft}$ bls in well $\mathrm{GW}-26, C$, at a lithologic contact below the coal layer at about $47 \mathrm{ft}$ bls in borehole $\mathrm{MW}-16 \mathrm{D}, D$, at a lithologic contact with possible thin bony coal seams near $27 \mathrm{ft}$ bls in borehole MW-6, E, at a lithologic contact below the coal layer at about $81 \mathrm{ft}$ bls in borehole MW-13D, and $F$, at a large opening near $34 \mathrm{ft}$ bls above the lithologic contact in borehole MW-17D, Valmont TCE Superfund Site, Luzerne County, Pennsylvania. 
However, these results may not be representative of fractures at depths not tested and should be considered with awareness of data limitations.

\section{Correlation of Geophysical Logs, Water Levels, and Selected Contaminant Concentrations}

Correlations of geophysical logs used to infer lithology were developed for selected cross sections at and near the Valmont TCE Superfund Site. The distribution of boreholes at the site with logs used for correlations are shown in figure 16. The lithologic cross sections were prepared at two scales, one more detailed and one more regional in scope. The detailedscale sections $\left(A_{d}-A_{d}{ }^{\prime}, B_{d}-B_{d}{ }^{\prime}, C-C^{\prime}, D-D^{\prime}, E-E^{\prime}, F-F^{\prime}\right.$ on fig. 16) focus on areas with the greatest density of geophysical logs and the area of greatest concern related to groundwater contamination at and near the former Chromatex Plant. The

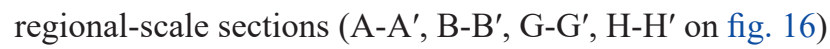
extend over greater distances and depths than the detailedscale sections.

Measured water levels and selected contaminant concentrations in samples from screened monitor wells across the Valmont TCE Superfund Site collected by Tetra Tech for the EPA during February-March 2020 (Tetra Tech NUS, Inc., 2016, 2020; U.S. Environmental Protection Agency, 2020a,b) are plotted on the cross sections developed using the updated lithologic correlations and also on plan-view maps for shallow and intermediate-to-deep wells to provide information about vertical and horizonal gradients, potential directions of groundwater flow, and vertical and horizontal distribution of contaminants in groundwater. For the plan-view maps, shallow wells were defined as having a depth to bottom of open interval as less than $60 \mathrm{ft}$ bls and intermediate-to-deep wells as having a depth to bottom of open interval between 60 and $400 \mathrm{ft}$ bls. Data for intermediate-to-deep wells are shown on plan-view maps with different symbols indicating three ranges in depth to bottom of the open interval: 60 to $99 \mathrm{ft}$ bls (intermediate depth); 100 to $149 \mathrm{ft}$ bls (deep); and 150 to $400 \mathrm{ft} \mathrm{bls}$ (very deep).

\section{Lithologic Correlations and Cross Sections}

Natural gamma, single-point resistance, and neutron density logs in open boreholes collected by USGS and others for the EPA at various times from 2002 through 2014 were used for lithologic correlations (table 1; fig. 16). Other data, such as OTV, ATV, and video logs were used to help identify lithologies and structural features such as faults. Cross sections were developed using lithologic-log correlation among boreholes for the sections shown on figure 16. Cross sections A-A' (plate 1), $A_{d}-A_{d}{ }^{\prime}$ (plate 2), B-B' (plate 3), B- $B_{d}{ }^{\prime}$ (plate 4), and $\mathrm{C}^{-\mathrm{C}^{\prime}}$ (plate 5) sections are oriented in northeast-southwest trending lines; cross sections D-D' (plate 6), E-E' (plate 7), F-F' (plate 8), G-G' (plate 9), and $\mathrm{H}-\mathrm{H}^{\prime}$ (plate 10) and oriented in northwest-southeast-trending lines (fig. 16).
Boreholes depicted on the cross sections as thin black lines represent the open interval during the time of geophysical logging, with available natural gamma, single-point resistance, neutron density, ATV, and OTV logs plotted adjacent to the borehole. Most boreholes were reconstructed with one or two screens after logging, and these screened intervals (as of 2020) are also included for reference on the cross sections. For the case where two boreholes were drilled in a cluster, only the deepest log is shown on cross sections, but the screened interval in the nearby shallow well in the cluster is included at appropriate depths on the cross sections. Well clusters with closely spaced separate boreholes having slightly different locations and land-surface elevations include MW-1, 2, 10, 11, 13, 14, 16, 17, 19, 20, and 21 (table 3).

All boreholes were projected onto the line of section, and distances between boreholes are based off that projection. Thus, there may be minor differences between distances depicted on the cross section and the true line distance between boreholes, particularly if boreholes were projected onto the cross section from different directions. No attempt was made to depict the details of land surface topography on the cross sections; land surface was depicted by connecting the land surface altitudes of boreholes only and should be considered generalized.

On the plates, natural gamma (gray lines), single-point resistance (red lines), and neutron density (purple lines) log data were converted from depth below land surface into NAVD 88 altitude based on the land surface altitude of their boreholes. OTV and ATV log images were extracted from their reported logs and scaled to the correct depths on the cross section. Principal correlations are between intervals with relatively higher natural gamma activity and lower singlepoint resistance on logs associated with shale lithology, and between intervals with relatively lower natural gamma activity and higher singe-point resistance on logs associated with sandstone and conglomerate lithologies. The logs were correlated between boreholes without any formal use of regional bedrock dip and strike. The vertical spacing between zones with relatively elevated natural gamma or single-point resistance values on logs, in addition to log shape and thickness of inferred lithologies, was considered as part of the correlation. However, as beds may not be laterally continuous or constant in thickness owing to original depositional environment, the exact spacing between correlated units may vary. The OTV and video logs were used to help confirm correlations by apparent lithology.

On the plates, correlations between high-natural gamma, low-single point resistance units are depicted with light gray shading for the Pottsville Formation and, in the deepest wells, pale yellow for the Mauch Chunk Formation, which represents predominantly shale, claystone, and siltstone lithology. The contact between the Pottsville Formation and underlying Mauch Chunk Formation is indicated by a distinctive increase of gamma intensity at depths ranging from about 200 to $220 \mathrm{ft}$ bls, as can be seen on plates 1, 3, and 10 (sections A-A', B-B', and $\mathrm{H}-\mathrm{H}^{\prime}$ on figure 16 , respectively). Low-density 


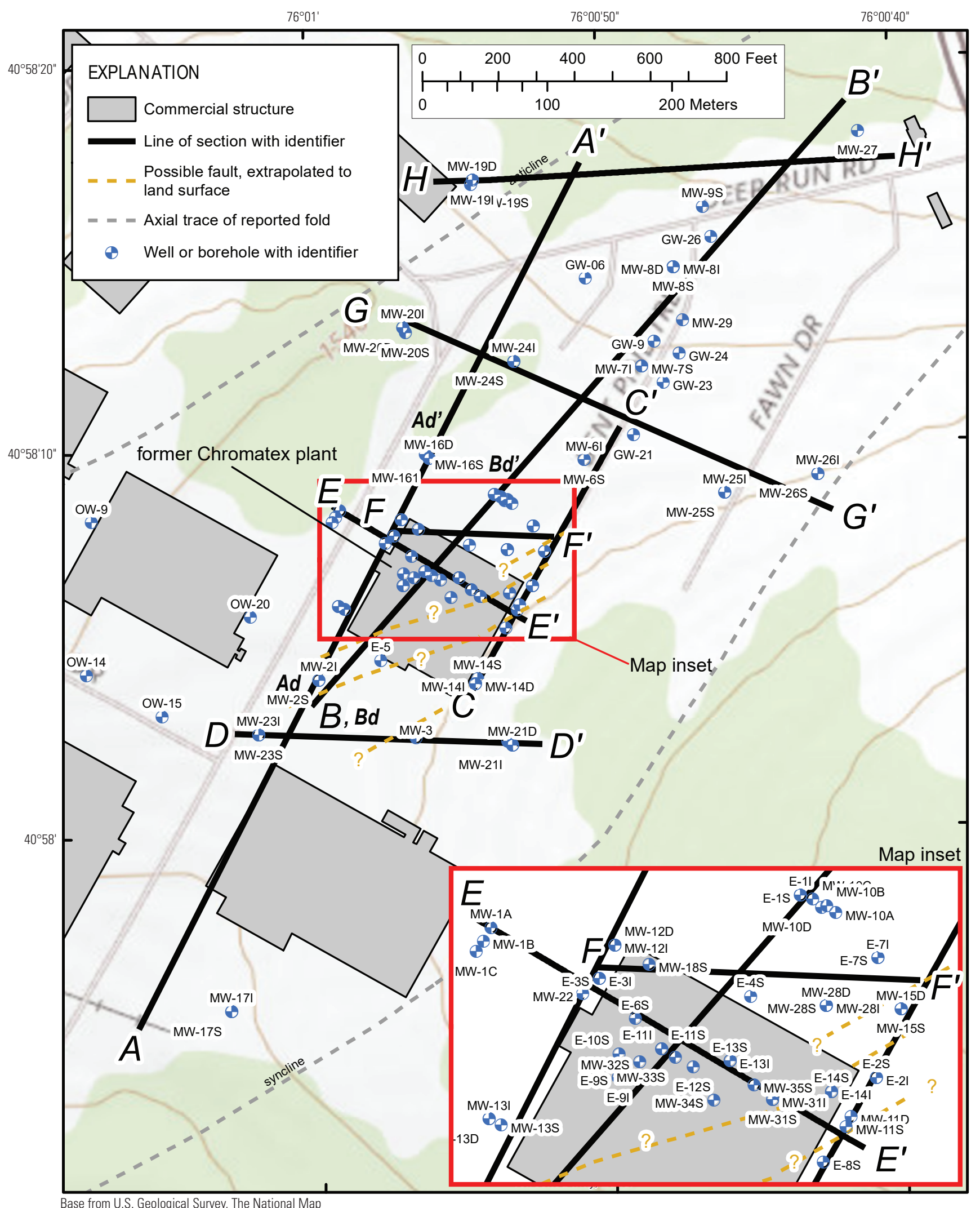

Figure 16. Selected mapped geologic structures and location of cross sections developed by the U.S. Geological Survey using geophysical log correlation at and near the Valmont TCE Superfund Site, Luzerne County, Pennsylvania. Geologic structure from Schasse and others (2012), with mapped approximate location of fold axes shown by dashed gray lines. 
Table 3. Water levels measured on March 4, 2020, in 76 wells; the results of laboratory analysis for trichloroethene (TCE), perfluorooctanoic acid (PFOA), and perfluorooctanesulfonic acid (PFOS) in groundwater samples collected from February 16 to March 3, 2020, in 75 wells; and characteristics of wells with water-level and sample data at Valmont TCE Superfund Site, Luzerne County, Pennsylvania. Water-level and contaminant concentration data from Tetra Tech NUS, Inc. (2020) and U.S. Environmental Protection Agency (2020 a,b). The 2016 and 2018 PFOA and PFOS concentrations are from U.S. Environmental Protection Agency (2016c, 2018b).

[EPA, U.S. Environmental Protection Agency; Lat_dd, latitude in decimal degrees; Long_dd, longitude in decimal degrees; ft, feet; bls, below land surface; LSA, land-surface altitude; NAVD 88, North American Vertical Datum of 1988; DTW, depth to water; WL, water level; PFAS, per- and polyfluoroalkyl substances; $\mu \mathrm{g} / \mathrm{L}$, micrograms per liter; ng/L, nanograms per liter; --, no data, <, less than; ?, indicates uncertainty in presence of shale in interval]

\begin{tabular}{|c|c|c|c|c|c|c|c|c|c|c|c|c|c|c|}
\hline \multirow[b]{2}{*}{$\begin{array}{l}\text { EPA local } \\
\text { well name }\end{array}$} & \multirow[b]{2}{*}{ Lat_dd } & \multirow[b]{2}{*}{ Long_dd } & \multicolumn{2}{|c|}{ Depth of open interval } & \multirow[b]{2}{*}{$\begin{array}{c}\text { Span } \\
\text { shale } \\
\text { contact }^{\mathrm{a}}\end{array}$} & \multirow[b]{2}{*}{$\begin{array}{c}\text { LSA }^{\mathrm{b}} \\
\text { in } \mathrm{ft} \text { above } \\
\text { NAVD } 88\end{array}$} & \multirow[b]{2}{*}{$\begin{array}{c}\text { DTW, } \\
\text { in ft bls }\end{array}$} & \multirow[b]{2}{*}{$\begin{array}{l}\text { WL altitude, } \\
\text { in ft above } \\
\text { NAVD } 88\end{array}$} & \multicolumn{4}{|c|}{ February-March 2020c concentrations } & \multirow[b]{2}{*}{$\begin{array}{l}\text { Year of } \\
\text { PFAS } \\
\text { sample }\end{array}$} & \multirow[b]{2}{*}{$\begin{array}{l}\text { PFOA/ } \\
\text { PFOS } \\
\text { ratio }\end{array}$} \\
\hline & & & $\begin{array}{c}\text { Depth to } \\
\text { top of } \\
\text { open interval, } \\
\text { in } \mathrm{ft} \text { bls }\end{array}$ & $\begin{array}{l}\text { Depth to } \\
\text { bottom of } \\
\text { open interval, } \\
\text { in ft bls }\end{array}$ & & & & & $\begin{array}{c}\text { TCE, } \\
\text { in } \mu g / L\end{array}$ & $\begin{array}{l}\text { PFOS, } \\
\text { in ng/L }\end{array}$ & $\begin{array}{l}\text { PFOA, } \\
\text { in ng/L }\end{array}$ & $\begin{array}{l}\text { PFOA plus } \\
\text { PFOS, } \\
\text { in ng/L }\end{array}$ & & \\
\hline E-1S & 40.969100 & -76.014932 & 19.0 & 34.0 & $\mathrm{X}$ & $1,538.20$ & 13.08 & $1,525.12$ & 700 & 662 & 243 & 905 & 2020 & 0.37 \\
\hline E-1I & 40.969100 & -76.014932 & 65.0 & 80.0 & $\mathrm{X}$ & $1,538.20$ & 18.64 & $1,519.56$ & 29 & 26.1 & 28.6 & 54.7 & 2020 & 1.10 \\
\hline E-2S & 40.968436 & -76.014586 & 35.0 & 50.0 & $\mathrm{O}$ & $1,538.40$ & 3.77 & $1,534.63$ & 37 & 78 & 68 & 146 & 2016 & 0.87 \\
\hline E-2I & 40.968436 & -76.014586 & 57.0 & 72.0 & $X$ & $1,538.40$ & 5.21 & $1,533.19$ & 14 & -- & -- & -- & 2020 & -- \\
\hline E-3S & 40.968814 & -76.015897 & 19.0 & 34.0 & $X$ & $1,542.72$ & 16.07 & $1,526.65$ & 300 & 484 & 136 & 620 & 2020 & 0.28 \\
\hline E-3I & 40.968814 & -76.015897 & 48.0 & 63.0 & $X$ & $1,542.72$ & 18.19 & $1,524.53$ & 4,500 & 293 & 526 & 819 & 2020 & 1.80 \\
\hline E-4S & 40.968736 & -76.015178 & 34.0 & 49.0 & $X$ & $1,541.98$ & 12.35 & $1,529.63$ & 1,200 & 802 & 293 & 1,095 & 2020 & 0.37 \\
\hline E-5 & 40.967918 & -76.016043 & 19.0 & $150^{\mathrm{d}}$ & -- & $1,542.51$ & 8.80 & $1,533.71$ & -- & -- & -- & -- & 2020 & -- \\
\hline E-6S & 40.968665 & -76.015730 & 24.0 & 39.0 & $\mathrm{O}$ & $1,543.18$ & 10.55 & $1,532.63$ & 91 & 260 & 51.3 & 311.3 & 2018 & -- \\
\hline E-7S & 40.968868 & -76.014569 & 23.0 & 38.0 & $X$ & $1,537.98$ & 9.64 & $1,528.34$ & 570 & 208 & 102 & 310 & 2020 & 0.49 \\
\hline E-7I & 40.968868 & -76.014569 & 48.0 & 63.0 & $X$ & $1,537.98$ & 13.20 & $1,524.78$ & 480 & 167 & 61.8 & 228.8 & 2020 & 0.37 \\
\hline E-8S & 40.968134 & -76.014848 & 22.0 & 37.0 & $\mathrm{O}$ & $1,542.79$ & 6.93 & $1,535.86$ & 15 & -- & -- & -- & 2020 & -- \\
\hline E-9S & 40.968454 & -76.015817 & 29.0 & 44.0 & $\mathrm{O}$ & $1,543.30$ & 9.56 & $1,533.74$ & 14,000 & 385 & 695 & 1,080 & 2020 & 1.81 \\
\hline E-9I & 40.968454 & -76.015817 & 50.0 & 70.0 & $\mathrm{X}$ & $1,543.30$ & 9.69 & $1,533.61$ & 8,100 & 590 & 513 & 1,103 & 2020 & 0.87 \\
\hline E-10S & 40.968539 & -76.015810 & 19.0 & 39.0 & $\mathrm{O}$ & $1,542.80^{\mathrm{b}}$ & 8.77 & $1,534.03$ & 190 & -- & -- & -- & 2020 & -- \\
\hline E-11S & 40.968555 & -76.015608 & 19.0 & 34.0 & $X$ & $1,542.75^{b}$ & 8.67 & $1,534.08$ & 55,000 & 969 & 1,390 & 2,359 & 2020 & 1.43 \\
\hline E-11I & 40.968555 & -76.015608 & 49.0 & 64.0 & $X$ & $1,542.75^{b}$ & 15.38 & $1,527.37$ & 17,000 & 48.4 & 349 & 397.4 & 2020 & 7.21 \\
\hline E-12S & 40.968488 & -76.015460 & 21.0 & 36.0 & $\mathrm{X}$ & $1,542.92^{\mathrm{b}}$ & 8.79 & $1,534.13$ & 9,000 & -- & -- & -- & 2020 & -- \\
\hline E-13S & 40.968506 & -76.015283 & 19.0 & 34.0 & $\mathrm{X}$ & $1,542.95^{\mathrm{b}}$ & 8.85 & $1,534.10$ & 1,100 & 507 & 360 & 867 & 2020 & 0.71 \\
\hline E-13I & 40.968506 & -76.015283 & 61.0 & 76.0 & $\mathrm{X}$ & $1,542.95^{\mathrm{b}}$ & 15.66 & $1,527.29$ & 230 & 18.2 & 24.9 & 43.1 & 2020 & 1.37 \\
\hline E-14S & 40.968388 & -76.014803 & 20.0 & 35.0 & $\mathrm{O}$ & $1,540.25^{b}$ & 5.64 & $1,534.61$ & 130 & -- & -- & -- & 2020 & -- \\
\hline E-14I & 40.968388 & -76.014803 & 62.0 & 82.0 & $\mathrm{X}$ & $1,540.25^{\mathrm{b}}$ & 8.96 & $1,531.29$ & 170 & -- & -- & -- & 2020 & -- \\
\hline MW-1A & 40.969004 & -76.016408 & 36.0 & 46.0 & $X$ & $1,547.14$ & 16.13 & $1,531.01$ & $<5.0$ & 21.1 & 12.7 & 33.8 & 2020 & 0.60 \\
\hline MW-1B & 40.968957 & -76.016447 & 55.0 & 80.5 & $\mathrm{O}$ & $1,547.44$ & 25.33 & $1,522.11$ & 3.5 & $<8.47$ & $<8.47$ & $<16.9$ & 2020 & -- \\
\hline MW-1C & 40.968919 & -76.016483 & 90.0 & 100.0 & $X$ & $1,547.30$ & 25.45 & $1,521.85$ & 2.7 & $<8.62$ & $<8.62$ & $<17.2$ & 2020 & -- \\
\hline MW-2S & 40.967786 & -76.016640 & 44.0 & 54.0 & $X$ & $1,535.43^{b}$ & 5.88 & $1,529.55$ & -- & 36.5 & 15.5 & 52 & 2020 & 0.42 \\
\hline MW-2I & 40.967786 & -76.016640 & 70.0 & 80.0 & $\mathrm{O}$ & $1,535.96$ & 6.70 & $1,529.26$ & 19 & $<8.62$ & $<8.62$ & $<17.2$ & 2020 & -- \\
\hline
\end{tabular}


Table 3. Water levels measured on March 4, 2020, in 76 wells; the results of laboratory analysis for trichloroethene (TCE), perfluorooctanoic acid (PFOA), and

perfluorooctanesulfonic acid (PFOS) in groundwater samples collected from February 16 to March 3, 2020, in 75 wells; and characteristics of wells with water-level and sample data at Valmont TCE Superfund Site, Luzerne County, Pennsylvania. Water-level and contaminant concentration data from Tetra Tech NUS, Inc. (2020) and U.S. Environmental Protection Agency (2020 a,b). The 2016 and 2018 PFOA and PFOS concentrations are from U.S. Environmental Protection Agency (2016c, 2018b).-CContinued

[EPA, U.S. Environmental Protection Agency; Lat dd, latitude in decimal degrees; Long_dd, longitude in decimal degrees; ft, feet; bls, below land surface; LSA, land-surface altitude; NAVD 88, North American Vertical Datum of 1988; DTW, depth to water; WL, water level; PFAS, per- and polyfluoroalkyl substances; $\mu \mathrm{g} / \mathrm{L}$, micrograms per liter; ng/L, nanograms per liter; --, no data, <, less than; ?, indicates uncertainty in presence of shale in interval]

\begin{tabular}{|c|c|c|c|c|c|c|c|c|c|c|c|c|c|c|}
\hline \multirow[b]{2}{*}{$\begin{array}{l}\text { EPA local } \\
\text { well name }\end{array}$} & \multirow[b]{2}{*}{ Lat_dd } & \multirow[b]{2}{*}{ Long_dd } & \multicolumn{2}{|c|}{ Depth of open interval } & \multirow[b]{2}{*}{$\begin{array}{c}\text { Span } \\
\text { shale } \\
\text { contact }^{\mathrm{a}}\end{array}$} & \multirow[b]{2}{*}{$\begin{array}{c}\text { LSA }^{\mathrm{b}} \\
\text { in ft above } \\
\text { NAVD } 88\end{array}$} & \multirow[b]{2}{*}{$\begin{array}{c}\text { DTW, } \\
\text { in ft bls }\end{array}$} & \multirow[b]{2}{*}{$\begin{array}{l}\text { WL altitude, } \\
\text { in ft above } \\
\text { NAVD } 88\end{array}$} & \multicolumn{4}{|c|}{ February-March 2020' concentrations } & \multirow[b]{2}{*}{$\begin{array}{c}\text { Year of } \\
\text { PFAS } \\
\text { sample }\end{array}$} & \multirow[b]{2}{*}{$\begin{array}{c}\text { PFOA/ } \\
\text { PFOS } \\
\text { ratio }\end{array}$} \\
\hline & & & $\begin{array}{c}\text { Depth to } \\
\text { top of } \\
\text { open interval, } \\
\text { in } \mathrm{ft} \text { bls }\end{array}$ & $\begin{array}{c}\text { Depth to } \\
\text { bottom of } \\
\text { open interval, } \\
\text { in ft bls }\end{array}$ & & & & & $\begin{array}{c}\text { TCE, } \\
\text { in } \mu \mathrm{g} / \mathrm{L}\end{array}$ & $\begin{array}{l}\text { PFOS, } \\
\text { in ng/L }\end{array}$ & $\begin{array}{l}\text { PFOA, } \\
\text { in ng/L }\end{array}$ & $\begin{array}{c}\text { PFOA plus } \\
\text { PFOS, } \\
\text { in ng/L }\end{array}$ & & \\
\hline MW-3 & 40.967355 & -76.015724 & 35.0 & 45.0 & $\mathrm{O}$ & $1,535.73$ & -- & -- & -- & -- & -- & -- & 2020 & -- \\
\hline MW-6S & 40.969337 & -76.014070 & 24.0 & 34.0 & $\mathrm{O}$ & $1,534.70$ & 12.85 & $1,521.85$ & 24 & 240 & 49.9 & 289.9 & 2020 & 0.21 \\
\hline MW-6I & 40.969337 & -76.014070 & 88.0 & 98.0 & $\mathrm{X}$ & $1,534.70$ & 20.83 & $1,513.87$ & 14 & $<8.93$ & $<8.93$ & $<17.8$ & 2020 & -- \\
\hline MW-7S & 40.970006 & -76.013505 & 34.0 & 44.0 & $\mathrm{X}$ & $1,525.25$ & 15.78 & $1,509.47$ & 56 & 15.1 & 20.8 & 35.9 & 2020 & 1.38 \\
\hline MW-7I & 40.970006 & -76.013505 & 58.0 & 68.0 & $X$ & $1,525.25$ & 21.08 & $1,504.17$ & 13 & $<8.93$ & 16.6 & 16.6 & 2020 & -- \\
\hline MW-8S & 40.970717 & -76.013184 & 35.0 & 60.0 & $\mathrm{X}$ & $1,514.44$ & 17.02 & $1,497.42$ & 18 & 27.6 & 21.2 & 48.8 & 2020 & 0.77 \\
\hline MW-8D & 40.970717 & -76.013184 & 97.0 & 112.0 & $\mathrm{X}$ & $1,514.44$ & 16.29 & $1,498.15$ & 2.7 & $<8.77$ & $<8.77$ & $<17.5$ & 2020 & -- \\
\hline MW-9S & 40.971149 & -76.012895 & 24.0 & 34.0 & $\mathrm{X}$ & $1,507.75$ & -- & -- & -- & -- & -- & -- & 2020 & -- \\
\hline MW-10D & 40.969054 & -76.014832 & 13.0 & 15.0 & -- & $1,537.97$ & -- & -- & -- & -- & -- & -- & 2020 & -- \\
\hline MW-10A & 40.969034 & -76.014765 & 36.0 & 46.0 & $\mathrm{X}$ & $1,537.71$ & 12.55 & $1,525.16$ & 620 & 1100 & 380 & 1480 & 2016 & 0.35 \\
\hline MW-10B & 40.969060 & -76.014807 & 65.0 & 75.0 & $\mathrm{X}$ & $1,537.79$ & 18.61 & $1,519.18$ & $<5.0$ & -- & -- & -- & 2020 & -- \\
\hline MW-10C & 40.969084 & -76.014873 & 104.0 & 114.0 & $\mathrm{X}$ & $1,538.33$ & 20.06 & $1,518.27$ & $<5.0$ & 19.9 & 20.1 & 40 & 2018 & 1.01 \\
\hline MW-11S & 40.968261 & -76.014736 & 44.0 & 54.0 & $\mathrm{O} ?$ & $1,539.07$ & 5.34 & $1,533.73$ & 2,500 & 35.3 & 29.6 & 64.9 & 2020 & 0.84 \\
\hline MW-11D & 40.968298 & -76.014711 & 96.0 & 106.0 & $\mathrm{X}$ & $1,539.03$ & 8.20 & $1,530.83$ & 190 & $<8.77$ & $<8.77$ & $<17.5$ & 2020 & -- \\
\hline MW-12S & 40.968932 & -76.015821 & 45.0 & 58.0 & $\mathrm{X}$ & $1,542.92$ & 18.80 & $1,524.12$ & 2,000 & -- & -- & -- & 2020 & -- \\
\hline MW-12I & 40.968932 & -76.015821 & 88.0 & 98.0 & $\mathrm{X}$ & $1,542.92$ & 16.66 & $1,526.26$ & 9.5 & -- & -- & -- & 2020 & -- \\
\hline MW-13S & 40.968292 & -76.016379 & 20.0 & 35.0 & $\mathrm{O} ?$ & $1,541.10$ & 7.19 & $1,533.91$ & 180 & 151 & 51.7 & 202.7 & 2020 & 0.34 \\
\hline MW-13I & 40.968313 & -76.016436 & 78.0 & 88.0 & $\mathrm{X}$ & $1,540.63$ & 15.45 & $1,525.18$ & 35 & 17.7 & 23.2 & 40.9 & 2020 & 1.31 \\
\hline MW-13D & 40.968313 & -76.016436 & 122.0 & 132.0 & $\mathrm{X}$ & $1,540.63$ & 18.93 & $1,521.70$ & $<5.0$ & $<8.93$ & $<8.93$ & $<17.9$ & 2020 & -- \\
\hline MW-14S & 40.967774 & -76.015124 & 35.0 & 50.0 & $\mathrm{O}$ & $1,542.68$ & 7.74 & $1,534.94$ & $<5.0$ & $<8.93$ & $<8.93$ & $<17.9$ & 2020 & -- \\
\hline MW-14I & 40.967738 & -76.015148 & 98.0 & 108.0 & $X$ & $1,542.60$ & 10.40 & $1,532.20$ & $<5.0$ & $<8.62$ & $<8.62$ & $<17.2$ & 2020 & -- \\
\hline MW-14D & 40.967738 & -76.015148 & 155.0 & 165.0 & $\mathrm{X}$ & $1,542.60$ & 12.13 & $1,530.47$ & $<5.0$ & 8.77 & $<8.77$ & $<17.5$ & 2020 & -- \\
\hline MW-15S & 40.968681 & -76.014462 & 48.0 & 58.0 & $\mathrm{X}$ & $1,537.97$ & 7.76 & $1,530.21$ & 7.7 & -- & -- & -- & 2020 & -- \\
\hline MW-15D & 40.968681 & -76.014462 & 90.0 & 105.0 & $\mathrm{X}$ & $1,537.97$ & 16.24 & $1,521.73$ & $<5.0$ & -- & -- & -- & 2020 & -- \\
\hline MW-16S & 40.969397 & -76.015582 & 30.0 & 45.0 & $\mathrm{O}$ & $1,539.44$ & 17.17 & $1,522.27$ & 6.2 & 9.86 & 10.9 & 20.76 & 2020 & 1.11 \\
\hline MW-16I & 40.969372 & -76.015545 & 66.0 & 86.0 & $X$ & $1,539.56$ & 19.38 & $1,520.18$ & 2.3 & $<8.93$ & 9.81 & 9.81 & 2020 & -- \\
\hline MW-16D & 40.969372 & -76.015545 & 104.0 & 114.0 & $\mathrm{O}$ & $1,539.56$ & 19.96 & $1,519.60$ & 7.5 & $<8.47$ & $<8.47$ & $<16.9$ & 2020 & -- \\
\hline
\end{tabular}


Table 3. Water levels measured on March 4, 2020, in 76 wells; the results of laboratory analysis for trichloroethene (TCE), perfluorooctanoic acid (PFOA), and perfluorooctanesulfonic acid (PFOS) in groundwater samples collected from February 16 to March 3, 2020, in 75 wells; and characteristics of wells with water-level and sample data at Valmont TCE Superfund Site, Luzerne County, Pennsylvania. Water-level and contaminant concentration data from Tetra Tech NUS, Inc. (2020) and U.S. Environmental Protection Agency (2020 a,b). The 2016 and 2018 PFOA and PFOS concentrations are from U.S. Environmental Protection Agency (2016c, 2018b).-Continued

[EPA, U.S. Environmental Protection Agency; Lat_dd, latitude in decimal degrees; Long_dd, longitude in decimal degrees; ft, feet; bls, below land surface; LSA, land-surface altitude; NAVD 88, North American Vertical Datum of 1988; DTW, depth to water; WL, water level; PFAS, per- and polyfluoroalkyl substances; $\mu \mathrm{g} / \mathrm{L}$, micrograms per liter; ng/L, nanograms per liter; --, no data, <, less than; ?, indicates uncertainty in presence of shale in interval]

\begin{tabular}{|c|c|c|c|c|c|c|c|c|c|c|c|c|c|c|}
\hline \multirow[b]{2}{*}{$\begin{array}{l}\text { EPA local } \\
\text { well name }\end{array}$} & \multirow[b]{2}{*}{ Lat_dd } & \multirow[b]{2}{*}{ Long_dd } & \multicolumn{2}{|c|}{ Depth of open interval } & \multirow[b]{2}{*}{$\begin{array}{c}\text { Span } \\
\text { shale } \\
\text { contact }^{\mathrm{a}}\end{array}$} & \multirow[b]{2}{*}{$\begin{array}{c}\text { LSA }^{\mathrm{b}} \\
\text { in } \mathrm{ft} \text { above } \\
\text { NAVD } 88\end{array}$} & \multirow[b]{2}{*}{$\begin{array}{c}\text { DTW, } \\
\text { in ft bls }\end{array}$} & \multirow[b]{2}{*}{$\begin{array}{l}\text { WL altitude, } \\
\text { in ft above } \\
\text { NAVD } 88\end{array}$} & \multicolumn{4}{|c|}{ February-March 2020' concentrations } & \multirow[b]{2}{*}{$\begin{array}{l}\text { Year of } \\
\text { PFAS } \\
\text { sample }\end{array}$} & \multirow[b]{2}{*}{$\begin{array}{c}\text { PFOA/ } \\
\text { PFOS } \\
\text { ratio }\end{array}$} \\
\hline & & & $\begin{array}{c}\text { Depth to } \\
\text { top of } \\
\text { open interval, } \\
\text { in } \mathrm{ft} \text { bls }\end{array}$ & $\begin{array}{c}\text { Depth to } \\
\text { bottom of } \\
\text { open interval, } \\
\text { in ft bls }\end{array}$ & & & & & $\begin{array}{c}\text { TCE, } \\
\text { in } \mu g / L\end{array}$ & $\begin{array}{l}\text { PFOS, } \\
\text { in ng/L }\end{array}$ & $\begin{array}{l}\text { PFOA, } \\
\text { in } n g / L\end{array}$ & $\begin{array}{l}\text { PFOA plus } \\
\text { PFOS, } \\
\text { in ng/L }\end{array}$ & & \\
\hline MW-17S & 40.965404 & -76.017529 & 36.0 & 44.0 & $\mathrm{X} ?$ & $1,522.09$ & 12.57 & $1,509.52$ & 1.1 & -- & -- & -- & 2020 & -- \\
\hline MW-17I & 40.965404 & -76.017529 & 56.0 & 66.0 & $\mathrm{X}$ & $1,522.00$ & 13.17 & $1,508.83$ & $<5.0$ & -- & -- & -- & 2020 & -- \\
\hline MW-18S & 40.968860 & -76.015660 & 14.0 & 36.0 & $\mathrm{X}$ & $1,543.19$ & 16.43 & $1,526.76$ & 940 & -- & -- & -- & 2020 & -- \\
\hline MW-19S & 40.971337 & -76.015098 & 50.0 & 60.0 & $\mathrm{X}$ ? & $1,514.46$ & -- & -- & -- & -- & -- & -- & 2020 & -- \\
\hline MW-19I & 40.971370 & -76.015081 & 66.0 & 76.0 & $\mathrm{X}$ & $1,513.99$ & 38.21 & $1,475.78$ & $<5.0$ & $<8.77$ & $<8.77$ & $<17.5$ & 2020 & -- \\
\hline MW-19D & 40.971370 & -76.015081 & 220.0 & 250.0 & $\mathrm{O}$ & $1,513.99$ & 52.43 & $1,461.56$ & $<5.0$ & $<8.93$ & $<8.93$ & $<17.9$ & 2020 & -- \\
\hline MW-20S & 40.970279 & -76.015745 & 40.0 & 55.0 & $\mathrm{O}$ & $1,535.79$ & 22.93 & $1,512.86$ & $<5.0$ & $<8.93$ & $<8.93$ & $<17.9$ & 2020 & -- \\
\hline MW-20D & 40.970317 & -76.015771 & 78.0 & 98.0 & $X$ & $1,536.34$ & 32.00 & $1,504.34$ & $<5.0$ & $<8.77$ & $<8.77$ & $<17.5$ & 2020 & -- \\
\hline MW-21S & 40.967315 & -76.014852 & 35.0 & 50.0 & $\mathrm{O}$ & $1,538.42$ & 9.70 & $1,528.72$ & $<5.0$ & 9.64 & 8.87 & 18.51 & 2020 & 0.92 \\
\hline MW-21I & 40.967289 & -76.014805 & 56.0 & 66.0 & $X$ & $1,538.47$ & 9.61 & $1,528.86$ & $<5.0$ & $<8.93$ & $<8.93$ & $<17.9$ & 2020 & -- \\
\hline MW-21D & 40.967289 & -76.014805 & 84.0 & 94.0 & $\mathrm{X}$ & $1,538.47$ & 12.89 & $1,525.58$ & $<5.0$ & $<8.93$ & $<8.93$ & $<17.9$ & 2020 & -- \\
\hline MW-22D & 40.968760 & -76.015978 & 294.0 & 304.0 & $\mathrm{X}$ & $1,542.86$ & 68.86 & $1,474.00$ & 240 & 156 & 352 & 508 & 2020 & 2.26 \\
\hline MW-23S & 40.967399 & -76.017221 & 62.0 & 72.0 & $\mathrm{X}$ & $1,533.64$ & 16.99 & $1,516.65$ & 30 & 11 & 12.5 & 23.5 & 2020 & 1.14 \\
\hline MW-23I & 40.967399 & -76.017221 & 88.0 & 98.0 & $X$ & $1,533.64$ & 19.82 & $1,513.82$ & 3.4 & $<8.62$ & $<8.62$ & $<17.2$ & 2020 & -- \\
\hline MW-24S & 40.970060 & -76.014720 & 34.0 & 44.0 & $X$ & $1,526.68$ & -- & -- & -- & -- & -- & -- & 2020 & -- \\
\hline MW-24I & 40.970060 & -76.014720 & 64.0 & 74.0 & $\mathrm{O}$ & $1,526.68$ & -- & -- & -- & -- & -- & -- & 2020 & -- \\
\hline MW-25S & 40.969081 & -76.012736 & 36.0 & 46.0 & $\mathrm{X}$ & $1,537.90$ & 8.73 & $1,529.17$ & $<5.0$ & $<9.09$ & $<9.09$ & $<18.2$ & 2020 & -- \\
\hline MW-25I & 40.969081 & -76.012736 & 92.0 & 102.0 & $\mathrm{O} ?$ & $1,537.90$ & 15.26 & $1,522.64$ & $<5.0$ & $<9.09$ & $<9.09$ & $<18.2$ & 2020 & -- \\
\hline MW-26S & 40.969204 & -76.011846 & 24.0 & 34.0 & $\mathrm{O}$ & $1,536.48$ & 4.59 & $1,531.89$ & $<5.0$ & 31 & $<8.77$ & 31 & 2020 & -- \\
\hline MW-26I & 40.969204 & -76.011846 & 102.0 & 112.0 & $\mathrm{X}$ & $1,536.48$ & 11.83 & $1,524.65$ & $<5.0$ & 8.98 & $<8.93$ & 8.98 & 2020 & -- \\
\hline MW-27 & 40.971667 & -76.011347 & 38.0 & 400.0 & -- & $1,494.00^{\mathrm{b}}$ & -- & -- & -- & $<8.6$ & $<8.6$ & $<17.2$ & 2018 & -- \\
\hline MW-28S & 40.968698 & -76.014819 & 35.0 & 45.0 & $X$ & $1,538.80$ & 12.11 & $1,526.69$ & 440 & -- & -- & -- & 2020 & -- \\
\hline MW-28I & 40.968706 & -76.014847 & 55.0 & 65.0 & $X$ & $1,539.00$ & 14.11 & $1,524.89$ & 14 & -- & -- & -- & 2020 & -- \\
\hline MW-28D & 40.968698 & -76.014819 & 140.0 & 150.0 & $\mathrm{O}$ & $1,538.80$ & -- & -- & -- & -- & -- & -- & 2020 & -- \\
\hline MW-29 & 40.970228 & -76.013233 & 19.0 & 251.0 & -- & $1,518.86$ & -- & -- & -- & -- & -- & -- & 2020 & -- \\
\hline MW-31S & 40.968364 & -76.015083 & 20.0 & 40.0 & $\mathrm{X}$ & $1,542.83^{\mathrm{b}}$ & 8.89 & $1,533.94$ & 300 & -- & -- & -- & 2020 & -- \\
\hline MW-31I & 40.968364 & -76.015083 & 69.0 & 79.0 & $X$ & $1,542.83^{\mathrm{b}}$ & 8.97 & $1,533.86$ & 5,600 & 160 & 150 & 310 & 2016 & 0.94 \\
\hline
\end{tabular}


Table 3. Water levels measured on March 4, 2020, in 76 wells; the results of laboratory analysis for trichloroethene (TCE), perfluorooctanoic acid (PFOA), and

perfluorooctanesulfonic acid (PFOS) in groundwater samples collected from February 16 to March 3, 2020, in 75 wells; and characteristics of wells with water-level and sample data at Valmont TCE Superfund Site, Luzerne County, Pennsylvania. Water-level and contaminant concentration data from Tetra Tech NUS, Inc. (2020) and U.S. Environmental Protection Agency (2020 a,b). The 2016 and 2018 PFOA and PFOS concentrations are from U.S. Environmental Protection Agency (2016c, 2018b).-Continued

[EPA, U.S. Environmental Protection Agency; Lat dd, latitude in decimal degrees; Long dd, longitude in decimal degrees; ft, feet; bls, below land surface; LSA, land-surface altitude; NAVD 88, North American Vertical Datum of 1988; DTW, depth to water; WL, water level; PFAS, per- and polyfluoroalkyl substances; $\mu \mathrm{g} / \mathrm{L}$, micrograms per liter; ng/L, nanograms per liter; --, no data, <, less than; ?, indicates uncertainty in presence of shale in interval]

\begin{tabular}{|c|c|c|c|c|c|c|c|c|c|c|c|c|c|c|}
\hline \multirow[b]{2}{*}{$\begin{array}{l}\text { EPA local } \\
\text { well name }\end{array}$} & \multirow[b]{2}{*}{ Lat_dd } & \multirow[b]{2}{*}{ Long_dd } & \multicolumn{2}{|c|}{ Depth of open interval } & \multirow[b]{2}{*}{$\begin{array}{c}\text { Span } \\
\text { shale } \\
\text { contact }^{\mathrm{a}}\end{array}$} & \multirow[b]{2}{*}{$\begin{array}{c}\text { LSA }^{\mathrm{b}} \\
\text { in ft above } \\
\text { NAVD } 88\end{array}$} & \multirow[b]{2}{*}{$\begin{array}{c}\text { DTW, } \\
\text { in ft bls }\end{array}$} & \multirow[b]{2}{*}{$\begin{array}{l}\text { WL altitude, } \\
\text { in ft above } \\
\text { NAVD } 88\end{array}$} & \multicolumn{4}{|c|}{ February-March $2020^{c}$ concentrations } & \multirow[b]{2}{*}{$\begin{array}{c}\text { Year of } \\
\text { PFAS } \\
\text { sample }\end{array}$} & \multirow[b]{2}{*}{$\begin{array}{c}\text { PFOA/ } \\
\text { PFOS } \\
\text { ratio }\end{array}$} \\
\hline & & & $\begin{array}{c}\text { Depth to } \\
\text { top of } \\
\text { open interval, } \\
\text { in } \mathrm{ft} \text { bls }\end{array}$ & $\begin{array}{c}\text { Depth to } \\
\text { bottom of } \\
\text { open interval, } \\
\text { in ft bls }\end{array}$ & & & & & $\begin{array}{c}\text { TCE, } \\
\text { in } \mu \mathrm{g} / \mathrm{L}\end{array}$ & $\begin{array}{l}\text { PFOS, } \\
\text { in ng/L }\end{array}$ & $\begin{array}{l}\text { PFOA, } \\
\text { in } n g / L\end{array}$ & $\begin{array}{c}\text { PFOA plus } \\
\text { PFOS, } \\
\text { in ng/L }\end{array}$ & & \\
\hline MW-32S & 40.968508 & -76.015714 & 13.0 & 33.0 & -- & $1,542.93^{b}$ & 9.03 & $1,533.90$ & 75,000 & 974 & 4270 & 5,244 & 2018 & 4.38 \\
\hline MW-33S & 40.968522 & -76.015543 & 9.0 & 29.0 & -- & $1,542.94^{b}$ & 8.73 & $1,534.21$ & 10,000 & -- & -- & -- & 2020 & -- \\
\hline MW-34S & 40.968364 & -76.015364 & 8.0 & 26.0 & -- & $1,542.84^{b}$ & 8.55 & $1,534.29$ & 200 & 150 & 180 & 330 & 2016 & 1.20 \\
\hline MW-35S & 40.968416 & -76.015170 & 6.5 & 26.5 & -- & $1,543.08^{b}$ & 8.68 & $1,534.40$ & 190 & -- & -- & -- & 2020 & -- \\
\hline GW-6 & 40.970646 & -76.014023 & -- & 92.0 & -- & -- & -- & -- & -- & -- & -- & -- & 2020 & -- \\
\hline GW-24 & 40.970094 & -76.013144 & 40.0 & 190.0 & -- & -- & -- & -- & -- & 27.7 & 28.7 & 56.4 & 2020 & 1.04 \\
\hline GW-23 & 40.969886 & -76.013302 & 150.0 & 180.0 & -- & -- & -- & -- & -- & -- & -- & -- & 2020 & -- \\
\hline RW-1 & 40.970531 & -76.010079 & -- & -- & -- & $1,507.37$ & -- & -- & -- & -- & -- & -- & 2020 & -- \\
\hline $\mathrm{K}-1$ & 40.970567 & -76.020879 & 32.0 & 243.0 & -- & $1,493.68$ & -- & -- & -- & -- & -- & -- & 2020 & -- \\
\hline OW-9 & 40.968953 & -76.018772 & -- & 40.0 & -- & $1,536.06$ & -- & -- & -- & -- & -- & -- & 2020 & -- \\
\hline OW-12 & 40.968402 & -76.019135 & -- & 40.0 & -- & $1,535.98$ & -- & -- & -- & -- & -- & -- & 2020 & -- \\
\hline OW-14 & 40.967852 & -76.018848 & -- & -- & -- & $1,533.49$ & -- & -- & -- & -- & -- & -- & 2020 & -- \\
\hline OW-15 & 40.967542 & -76.018138 & -- & 28.0 & -- & $1,531.81$ & -- & -- & -- & -- & -- & -- & 2020 & -- \\
\hline OW-20 & 40.968246 & -76.017277 & -- & 55.0 & -- & $1,539.93$ & -- & -- & -- & -- & -- & -- & 2020 & -- \\
\hline DL-01 & 40.972840 & -76.012264 & -- & 250.0 & -- & $1465.5^{b}$ & -- & -- & -- & -- & -- & -- & 2020 & -- \\
\hline DL-02 & 40.973450 & -76.016388 & -- & 290.0 & -- & $1469.2^{\mathrm{b}}$ & -- & -- & -- & -- & -- & -- & 2020 & -- \\
\hline
\end{tabular}

aScreen interval spans contact between shale and sandstone/conglomerate if value $=\mathrm{X}$ or does not span contact if value $=\mathrm{O}$.

${ }^{b}$ Values were estimated from light detection and ranging (lidar) digital elevation data; if no footnote, values determined from survey.

CConcentration data for samples collected during February-March 2020 except for a few samples collected in prior years listed in Year of PFAS sample

dWell depth for E-5 is reported to be $100 \mathrm{ft}$ in Tetra Tech NUS, Inc. (2016) but well was drilled to $150 \mathrm{ft}$ and is not known to have been reconstructed. 
intervals on logs that indicate coal beds are depicted as black rectangles on the cross sections. Sandstone and (or) conglomerate lithologies are indicated for intervals that are not shaded on the cross sections. Although attempts were made to maintain the same scaling factors for geophysical logs on the cross sections, the differences of log sources, tools and tool settings, and inherent natural geophysical variations require different scaling for legibility on the cross sections. Thus, no interpretation based on specific geophysical values should be made using these cross sections without consulting the individual $\log$ files.

The geological mapping of this area by Schasse and others (2012) was at a 1:24,000 scale, which is lower resolution than the 1:3,600 scale used in maps for this study. Thus, the locations of structural features and geologic contacts from Schasse and others (2012) are not necessarily accurate at the scale of this assessment. However, certain features such as the 200-ft thickness of the Pottsville Formation overlying the Mauch Chunk Formation reported by Schasse and others (2012) correspond to the thickness indicated on geophysical logs.

Overall, cross section lithologic-log correlations indicate southeast-dipping beds from the anticline axis northwest of the former Chromatex Plant toward the syncline axis southeast of the Plant, as would be expected from regional structures as mapped by Schasse and others (2012). However, there is additional tilting of the beds toward the northeast, which indicates possible plunging of the fold structures in that direction. Sections A-A', B-B', and C-C' (plates 1, 3, and 5) indicate this northeast-tilting trend of the beds, whereas sections E-E' (plate 7), G-G' (plate 9), and to a lesser extent H-H' (plate 10) indicate the anticline-to-syncline dip. Notably, sections D-D' (plate 6) and F-F' (plate 8) generally show beds with minor changes in altitude, indicating these sections are more aligned with a local approximate west to east strike direction that differs from the orientation of regional fold axes that strike more to the southwest-northeast (fig. 4). However, because many of the boreholes are projected onto the cross sections from different distances and directions, strike and dip orientations should not be determined using cross sections alone without transferring bed altitude information to map view as in figure 7. The limited area in the vicinity of the former Chromatex Plant where a particular bed at the top of a fining-upward sequence could be correlated indicates this feature generally has an eastnortheast strike and dips to the southeast (fig. 7).

Discontinuities in correlations may be associated with faults or lateral variability in bed thickness during sedimentary deposition. On the basis of information from geophysical and video logs for individual wells, numerous faults of variable displacement are indicated along the southeastern and southwestern portions of the study area.

The northeast-dipping beds are shallowest between boreholes MW-12 and MW-16 on section A-A' (plate 1) and between boreholes E-1/MW-10 and MW-6 on section B-B' (plate 3). To the southwest of these boreholes, the beds near boreholes MW-12 and E1/MW-10 dip in the opposite direction toward the southwest until they reach an inferred fault between boreholes MW-2 and MW-13 that intersects borehole E-5 (plates 1 and 3). It is unclear whether this change of dip direction is associated with their location on the down-thrusted side of the fault, whether the change is associated with a minor anticline, or some other reason. On the southern, up-thrusted side of this fault, too few geophysical log data are available south of the former Chromatex Plant to further delineate the structure in that area, although it is possible that the beds there dip to the southwest.

A fault near the depth of about $49 \mathrm{ft}$ was noted in the geophysical log report for borehole E-5 (Tetra Tech NUS, Inc., 2010), where apparent fault brecciation may be indicated by the OTV $\log$. The presence of this fault is also indicated by $\log$ correlations among boreholes E-5, MW-2, and MW-13 (section B-B', plate 3). On section A-A' and $A_{d}-A_{d}$ (plates 1 and 2), upward displacement in borehole MW-2 relative to borehole MW-13 indicates a minor thrust fault may be present. A relatively higher degree of weathering reported in the drillers log of borehole MW-13 compared to elsewhere at the Site may be caused by this fault propagating upward into shallower depths toward that well. Lithologic units in borehole MW-2 are well-correlated with those in borehole E-5 on sections B-B' and $B_{d}-B_{d}{ }^{\prime}$ (plates 3 and 4), particularly above the 49-ft depth of the fault reported by Tetra Tech NUS, Inc. (2010) in E-5. Lithologic units correlated between those boreholes are also approximately similar elevations, which may indicate these two boreholes are parallel to the strike of the fault. Borehole MW-2 is more than $50 \mathrm{ft}$ shallower than E-5, and so does not intersect the fault. Another possible fault was drawn between boreholes MW-2 and MW-23 on section A-A' (plate 1). This interpretation is based on additional fault interpretations on section $\mathrm{C}^{-\mathrm{C}^{\prime}}$ (plate 5), but no other additional evidence, owing to a lack of data in the southwestern portion of the study area.

Although geophysical log data on most cross sections indicated consistent correlations, the logs on section C-C' (plate 5) indicated a more complex structure. Relatively high-gamma, low-resistance units are more poorly correlated between boreholes on this section than on some other sections, such as A-A' and B-B', at and near the Site. For example, at altitudes between approximately 1,460 and $1,490 \mathrm{ft}$ above NAVD 88 on section $\mathrm{C}^{-C^{\prime}}$ (plate 5), all four boreholes from MW-14 to E-14 indicate alternating quantities of approximately 10 -ft thick relatively high-gamma, low-resistance units; MW-14 indicates one, E-8 indicates two, MW-11 indicates one, and E-14 indicates two (plate 5; see also appendix 1, figures 1.12, 1.14, and 1.16 for logs of E-14, MW-11, and MW-14, respectively). Absent geologic structure effects, how these units would be correlated is unknown. However, changes in bedding orientations and brecciation shown on the video logs of boreholes MW-11 (fig. 13) and MW-15 (fig. 12) indicate possible faulting near this area. Faults on C-C' (plate5) are interpreted as a series of minor faults with less displacement than that between boreholes MW-2 and MW-13 on section A-A' (plate 1). In this interpretation, the variable number of high-gamma/low resistance units on section $\mathrm{C}^{-\mathrm{C}^{\prime}}$ 
(plate 5) would represent overlapping displacements of the same lithologic unit by a series of low-angle faults similar to those found south of the Site and described by Reese (2016). The presence of the large hill beginning with a break in slope (steeper) directly to the southeast of C-C' (figs. 1, 5, and 16) adds plausibility to this interpretation. The hill is a topographic high (figs. 1 and 5) but is where the axis of the southeast syncline was tentatively mapped by Schasse and others (2012) (fig. 4), suggesting that the hill could potentially be an upthrust block similar to the more regional upthrust syncline described by Reese (2016). Section C-C', being located at the base of the hill, is more likely to see those effects compared to areas farther away. Four possible faults were mapped on section C-C' (plate 5), but their exact configurations are unknown, especially at depth where high gamma/low resistance units are poorly correlated. The fault between boreholes E-8 and MW-11 (C-C' section on plate 5) was interpreted to connect with the possible fault between boreholes MW-2 and MW-23 (A-A' section on plate 1 and fig. 16). The fault between boreholes E-2 and MW-15 (C-C' section on plate 5) was interpreted to connect with the fault between boreholes MW-13 and MW-2 that also intersects borehole E-5 (B-B' section on plate 3 and fig. 16).

The possible fault on section C-C' (plate 5) that intersects the shallow portion of MW-14 was interpreted partly from the lack of correlations between boreholes MW-14 and MW-21 to the southeast on section D-D' (plate 6), particularly the $30-\mathrm{ft}$ thick relatively high gamma/low resistance unit at about an altitude of 1,480 ft above NAVD 88 on MW-21 (plate 6) that is not present on MW-14 (plate 5). Data are sparse for section D-D' (plate 6), but the log for borehole MW-23 shows that shallower high gamma/low resistance units are not present on the $\log$ for borehole MW-21. The fault between boreholes MW-14 and MW-21 likely extends somewhere between boreholes MW-3 and MW-21 and is also likely a low angle fault for much of section D-D' (plate 6). No additional data are available from section D-D' to analyze geologic structure beyond these correlations.

The possible fault connection between boreholes MW-15 and E-2 on section C-C' (plate 5) and MW-13 and MW-2 on section A-A' (plate 1) requires the fault to cross section E-E' (plate 7) between boreholes MW-31 and MW-11, the latter of which is present on both C-C' and E-E' and through which this fault intersects. Boreholes MW-31 and MW-11 are poorly correlated, and the displacement of units and orientation of the fault are unknown, but the poor correlations are likely caused by faulting.

Cross-section correlations also confirm that some coal beds that occur near the top of fining-upward sequences are laterally extensive, at least in the vicinity of the former Chromatex Plant. This is most apparent in section E-E' (plate 7), which shows coal beds at the top of two separate correlated beds between boreholes E-3 and E-6; one from an altitude of about 1,486 ft in E-3 to an altitude of about 1,480 ft above NAVD 88 in E-6, and another from an altitude of about $1,464 \mathrm{ft}$ in E-3 to an altitude of 1,455 ft above NAVD 88 in
E-6. Few boreholes had density logs to interpret coal beds and drillers logs are not reliable for mapping locations of subsurface coal units for correlation purposes, so the lack of coal indicated at other boreholes is because of the lack of density logs and the interpretation should not be read as no coal present.

\section{Water Levels}

Water levels were measured in 76 screened monitor wells across the Valmont TCE Superfund Site by Tetra Tech for the EPA on March 4, 2020 (Tetra Tech NUS, Inc., 2020). The screened monitor wells (table 3 ) include reconstructed open boreholes with geophysical logs collected prior to reconstruction (wells designated with prefix $\mathrm{E}$ and deep and intermediate depth monitor wells designated with prefix MW; table 2) and also any adjacent shallow (mostly MW series) wells drilled as separate boreholes in a well cluster (Tetra Tech NUS, Inc., 2004b, 2010, 2011, 2014, 2016). The reconstructed wells were renamed to designate relative depths of shallow (S), intermediate (I), or deep (D) (table 3), superseding names with the suffix "D" assigned to some open boreholes at the time of drilling (table 2) but before reconstruction.

As measured on March 4, 2020, the depth to water ranged from about 3.77 to $68.9 \mathrm{ft}$ bls in the screened monitor wells (table 3). Water-level altitudes measured in the month of March generally are expected to be among the highest during each year, as shown by seasonal patterns in water-level data for nearby long-term observation well CB-104 (completed in the Mauch Chunk Formation), in which water levels typically are highest during March-April and lowest during AugustOctober (fig. 6A). Water levels in nearby long-term observation well CB-104 (fig. 2) during March 2020 were near long-term median values for that month (fig. $6 A$ ), indicating probable similar hydrologic conditions of seasonal high groundwater levels for the March 4, 2020, set of water levels at the Valmont TCE Superfund Site. Although seasonal fluctuations in water levels commonly are about $30 \mathrm{ft}$ per year (from minimum to maximum) in long-term observation well CB-104, the magnitude of seasonal water-level fluctuations in wells at the Site is not known.

Water-level altitudes as plotted and contoured on planview maps for shallow (less than $60 \mathrm{ft}$ bls) and intermediate (depth to bottom of opening ranging from 60 to $99 \mathrm{ft}$ bls) wells indicate potentiometric surfaces that are approximately similar to topography, with the highest water-level altitudes (and least depths to water) in shallow wells at the base of the hill bounding the southeast side of the Valmont TCE Superfund Site (figs. 1 and 5) and decreasing altitudes to the northeast, northwest, and southwest (figs. 17 and 18). Water-level contours were estimated by interpolating observed values by hand, without formal statistical processing of the data. Too few data are available for open intervals ranging in depth from 100 to $400 \mathrm{ft}$ bls to allow contouring of levels in that depth range. A northwest-trending groundwater divide likely is present in the vicinity of the southern half of the former Chromatex Plant as 


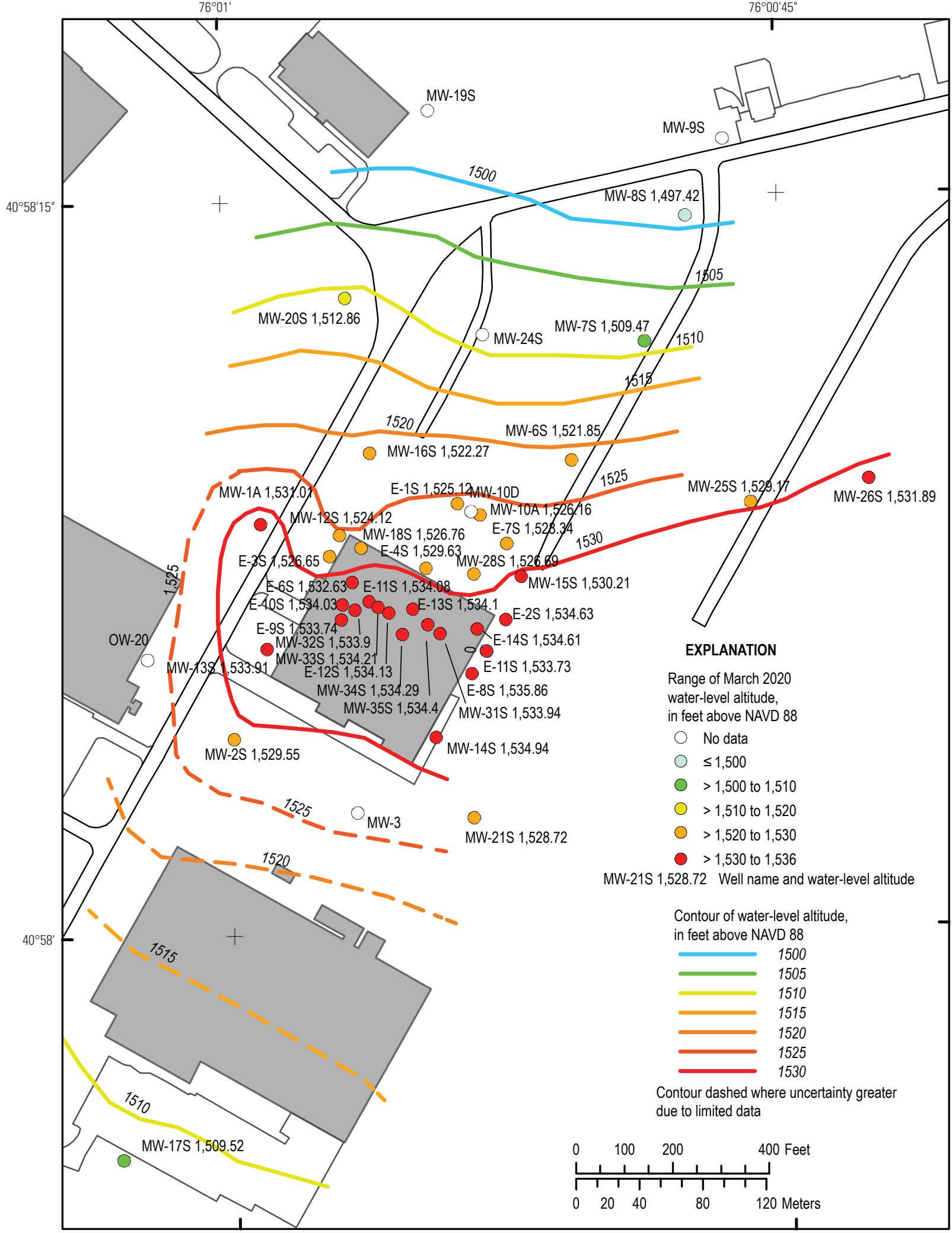

Figure 17. Water-level altitudes measured on March 4, 2020, and contoured water-level altitudes for wells with depths to bottom of screened or open interval less than 60 feet below land surface, Valmont TCE Superfund Site, Luzerne County, Pennsylvania. Contours are approximate. Data from Tetra Tech NUS, Inc. (2020). 


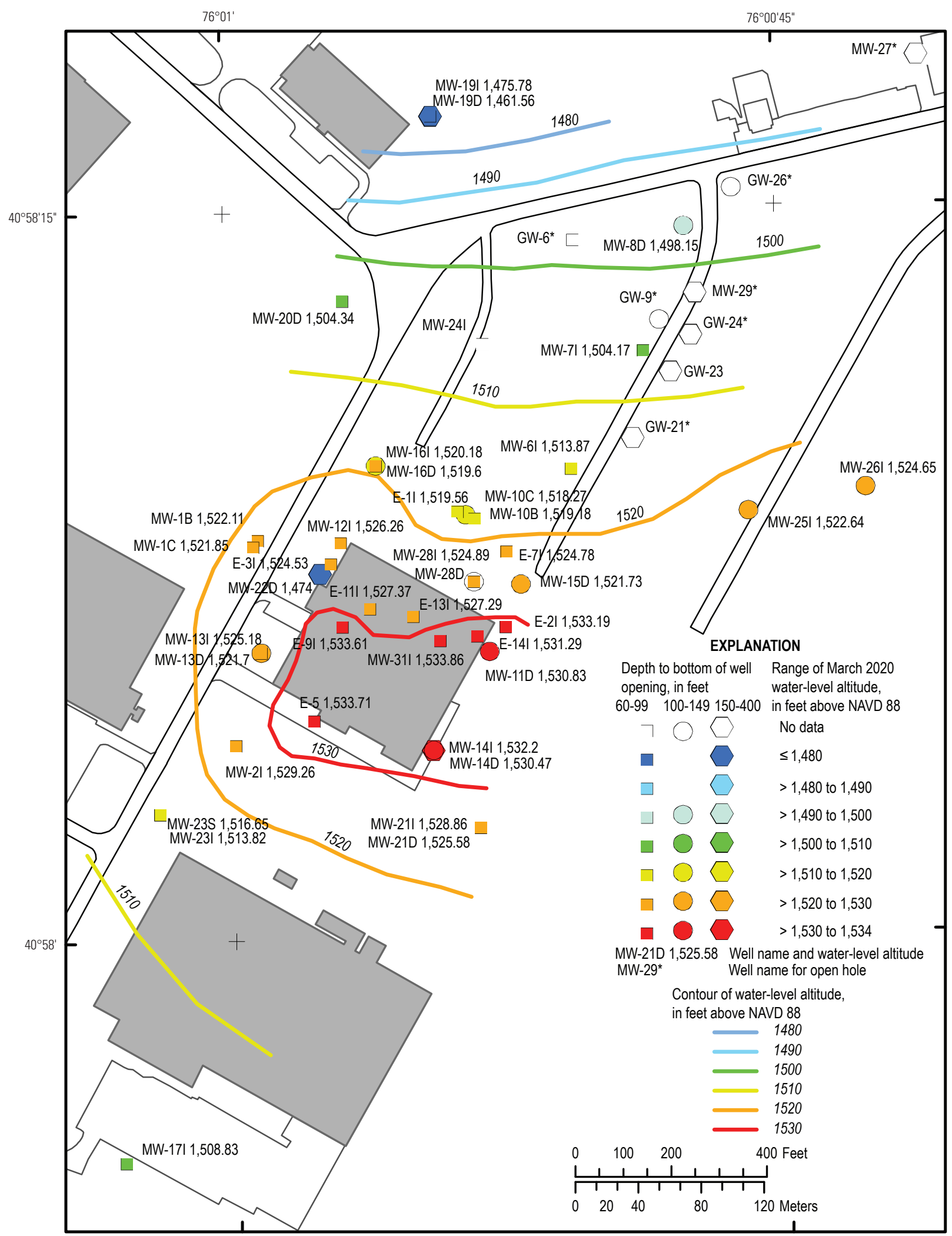

Figure 18. Water-level altitudes measured on March 4, 2020, and contoured water-level altitudes for wells with depths to bottom of screened or open interval greater than or equal to 60 feet $(\mathrm{ft}$ ) below land surface, with different symbols for ranges of bottom depth (60-99 ft; 100-149 ft; 150-400 ft), Valmont TCE Superfund Site, Luzerne County, Pennsylvania. Contours are approximate and primarily based on data from wells open from depths ranging from 60 to $100 \mathrm{ft}$. Data from Tetra Tech NUS, Inc. (2020). 
indicated by water levels in both the shallow and intermediatedepth wells, and as has been mapped previously (Tetra Tech NUS, Inc., 2016).

Comparison of water levels for all wells shown on the plan-view maps (figs. 17 and 18) and in table 3 indicates downward vertical hydraulic gradients. Water-level altitudes in the deepest open intervals in wells MW-19D (open 220-250 ft) and MW-22 (open 294-304 ft) are close in value $(1,461.56$ and $1,474.0 \mathrm{ft}$ above NAVD 88$)$ to nearby stream elevations in Black Creek, which is estimated to range from about 1,445 to $1,455 \mathrm{ft}$ above NAV88 (fig. 1).

Water-level altitudes were also contoured as potentiometric surfaces on cross sections developed using lithologic log correlations to better determine vertical distribution of hydraulic heads. On sections A-A' (plate 11), $A_{d}-A_{d}$ (plate 12), B-B' (plate 13), $\mathrm{B}_{\mathrm{d}}-\mathrm{B}_{\mathrm{d}}{ }^{\prime}$ (plate 14), C-C' (plate 15), E-E' (plate 16), F-F' (plate 17), and G-G' (plate 9), natural gamma logs and density log-derived coal beds remain on the hydrologic cross sections for reference. Sections D-D' (plate 6) and H-H' (plate 10) had relatively fewer geophysical data, so the water-level altitudes were included on the lithologic correlation section. Section H-H' had only one well with data, so no potentiometric surface contours were included on that section. Cross sections do not extend far enough to show where groundwater discharges to streams, although that process will occur once a stream is encountered.

Water-level contouring on these maps and cross sections assumed a traditional porous media approach. However, groundwater flow directions in anisotropic fractured rock aquifers are dependent on hydraulic gradients, fracture connectivity, and geometry, including fracture orientations related to bedding or other structural features; those inferred here are only partly realistic and should be considered generalized.

Potentiometric surfaces on cross sections indicate overall downward hydraulic gradients, and radial hydraulic gradients with potential for groundwater flow laterally to the northeast, southwest, and west or northwest, consistent with the general map views (figs. 17 and 18). However, groundwater-flow directions cannot be estimated solely on the basis of hydraulic gradients owing to the heterogeneity and anisotropy of the aquifer, which are related to geologic controls (structure, lithology) on water-bearing fracture occurrence and orientation. Southwest-northeast aligned sections A-A' (plate 11) and B-B' (plate 13) indicate a groundwater divide that coincides with the location of the inferred fault associated with boreholes MW-2, MW-13, and E-5. North of this fault, the hydraulic heads indicate a potential overall flow direction toward the northeast. South of the fault, hydraulic heads indicate potential for groundwater flow to the southwest. Although the presence of this fault could affect the location of this divide by introducing discontinuity in water-bearing features aligned with bedding, it is not clear whether this fault acts as a barrier or a conduit for groundwater flow. Both fracturing and brecciation occur in borehole E-5 where the fault zone intersects the borehole, features which would enhance (act as conduit) rather than reduce (act as barrier) groundwater flow. Section C-C' (plate 15) occurs northeast of this divide, and water levels on this section also indicate potentials for an overall flow direction toward the northeast.

Water levels on section C-C' (plate 15) may also indicate the hydraulic effects the hill to the southeast of the former Chromatex Plant imposes on the groundwater system. The hill may be likely to receive less infiltration and produce more downslope runoff than the saddle topographic setting of the former Chromatex Plant because of the hill's relatively steeper slopes (fig. $5 A$ ). Therefore, that extra downslope runoff may accumulate at the base of the hill on the southeast side of the former Chromatex Plant and increase recharge at that location, which is where section $\mathrm{C}-\mathrm{C}^{\prime}$ crosses. The highest hydraulic heads in the study area occurred on section C-C' in wells at the base of the hill, with the highest altitude being $1,535.86 \mathrm{ft}$ NAVD 88 in borehole E-8S.

Sections D-D' (plate 6), E-E' (plate 16), F-F' (plate 17), and $\mathrm{G}^{-} \mathrm{G}^{\prime}$ (plate 9) are oriented in a northwest-southeast or west-east direction and indicate an additional flow direction toward the west or northwest, from the syncline toward the anticline. Notably, the northeast flow direction follows the general tilting of the beds in that direction, whereas the west or northwest flow direction occurs in the opposite direction of bedding orientation.

Local flow direction anomalies that are inconsistent with the generalized flow directions indicated by the potentiometric surfaces also occur on the cross sections. These anomalies include the relatively high hydraulic head in borehole MW12I on section A-A' (plates 11 and 12), the approximately 9-ft head gradient in water levels between boreholes MW-1A and MW-1B on section E-E' (plate 16), the apparent minor groundwater divide associated with borehole E-4S on section F-F' (plate 17), the head-gradient reversals between the water levels in boreholes MW-28S/MW-28I cluster and E-7S/E-7I cluster on section F-F' (plate 17), and effects of faulting on head distribution described earlier. The so-called anomalies may (1) have resulted from the traditional porous media approach used to contour the potentiometric surfaces not fully representing the heterogeneity and anisotropy associated with fractured rock aquifers, (2) be artifacts of the projection of wells onto cross sections from varying distances and directions that caused misleading characteristics, (3) result from potential problems in well construction, or (4) reflect some uncertainty in the data. The anomalous water level measurements in these wells, if assumed to represent actual hydraulic-head conditions, indicate additional complexity in the groundwater flow system that is not well characterized.

\section{Selected Contaminants}

Groundwater samples were collected from February 17 to March 3, 2020, from selected wells across the Valmont TCE Superfund Site by Tetra Tech for the EPA and analyzed for VOCs, selected metals, and PFAS compounds (U.S. Environmental Protection Agency, 2020a, b). During the February-March 2020 collection event, open-hole wells were 
not sampled, and analyses for PFAS and metals were not done on all samples. TCE, PFOA, and PFOS concentrations in samples collected from wells during February-March 2020 for VOC and PFAS analyses are listed in table 3, which also lists the sum of PFOA plus PFOS concentrations (value to be related to HA levels set by the EPA) and the ratio of PFOS to PFOA concentrations (for possible differentiation of PFAS sources and assessment of PFAS transport pathways on site). The most recent sitewide sampling prior to this was done in March 2016, just after reconstruction of numerous open-hole wells previously used for permanganate injections as part of remediation (Tetra Tech NUS, Inc., 2016).

Of the VOCs analyzed in groundwater samples collected from 75 wells in 2020, TCE was the most frequently detected compound and was measured at high concentrations, with a maximum value of $75,000 \mu \mathrm{g} / \mathrm{L}$ (table 4). About 65 percent (49 of 75) of the samples had a TCE concentration greater than the MCL of $5 \mu \mathrm{g} / \mathrm{L}$ established by the EPA for drinking water (table 4). The next most frequently detected compounds were 1,1,1-TCA, cis-1,2-DCE, 1,1-DCE, and 1,1,2-trichloro-1,2,2trifluoroethane (CFC-113), with maximum concentrations of $590,370,110$, and $69 \mu \mathrm{g} / \mathrm{L}$, respectively. Of these compounds, concentrations of 1,1-DCE exceeded the respective MCL most frequently, with 5 of 75 (6.6 percent) of samples having concentrations greater than $7 \mu \mathrm{g} / \mathrm{L}$ (table 4).

The February-March 2020 TCE concentrations are plotted on cross sections developed using updated lithologic correlations (plates 9-17) and plan-view maps (figs. 19 and 20). The cross sections and plan-view maps show that TCE concentrations generally are higher in samples from shallow wells (less than $60 \mathrm{ft}$ bls in depth) than from intermediate-todeep wells (60 to $400 \mathrm{ft}$ bls in depth). The highest $2020 \mathrm{TCE}$ concentrations (greater than $3,000 \mu \mathrm{g} / \mathrm{L}$ ) are in groundwater samples from wells MW-32S, E-11S, E-11-I, E-9S, MW-33S,

Table 4. Maximum concentrations reported for volatile organic compounds (VOCs) detected in analyses of groundwater samples collected from 75 wells at Valmont TCE Superfund Site, Luzerne County, Pennsylvania, February 16 to March 3, 2020. Data from the U.S. Environmental Protection Agency (2020a). Compounds listed in the table do not include a few tentatively identified compounds reported above detection levels in a few wells. Drinking-water standards from U.S. Environmental Protection Agency (2018a).

[MCL, maximum contaminant level for drinking water; $\mu \mathrm{g} / \mathrm{L}$, micrograms per liter; --, no data; J, indicates estimated value]

\begin{tabular}{|c|c|c|c|c|c|c|}
\hline Compound & $\begin{array}{l}\text { Compound } \\
\text { abbreviation }\end{array}$ & $\begin{array}{c}\text { Number of } \\
\text { samples with } \\
\text { detection }\end{array}$ & MCL, in $\mu \mathrm{g} / \mathrm{L}$ & $\begin{array}{c}\text { Number of } \\
\text { wells with } \\
\text { concentration } \\
\text { greater than MCL }\end{array}$ & $\begin{array}{c}\text { Maximum } \\
\text { concentration, } \\
\text { in } \mu \mathrm{g} / \mathrm{L}\end{array}$ & $\begin{array}{l}\text { Well with } \\
\text { maximum } \\
\text { concentration }\end{array}$ \\
\hline \multicolumn{7}{|c|}{ Most frequently (more than 4 wells) detected compounds at concentrations above reporting level of $5 \mu \mathrm{g} / \mathrm{L}$} \\
\hline 1,1-Dichloroethane & $1,1-\mathrm{DCA}$ & 6 & -- & -- & 11 & MW-31I \\
\hline 1,1-Dichloroethene & $1,1-\mathrm{DCE}$ & 19 & 7 & 5 & 110 & MW-31I \\
\hline Tetrachloroethene & PCE & 7 & 5 & 1 & 13 & MW-32S \\
\hline Trichloroethene & TCE & 55 & 5 & 49 & 75,000 & MW-32S \\
\hline 1,1,1,-Trichloroethane & $1,1,1-\mathrm{TCA}$ & 46 & 200 & 1 & 590 & MW-31I \\
\hline 1,1,2-Trichloro-1,2,2-trifluoroethane & CFC-113 & 16 & -- & -- & 69 & MW-32S \\
\hline Benzene & & 1 & 5 & 0 & $2.2 \mathrm{~J}$ & MW-32S \\
\hline 2-Butanone & & 2 & -- & -- & $8.4 \mathrm{~J}$ & E-1I \\
\hline Bromodichloromethane & & 1 & 80 & -- & $1.5 \mathrm{~J}$ & MW-32S \\
\hline Carbon tetrachloride & & 4 & 5 & 1 & 8.4 & MW-32S \\
\hline Chloroform & & 4 & 80 & 0 & $2.6 \mathrm{~J}$ & MW-11S \\
\hline Chloromethane & & 1 & -- & -- & $1.7 \mathrm{~J}$ & MW-15S \\
\hline Ethylbenzene & & 1 & 70 & 0 & $0.74 \mathrm{~J}$ & MW-32S \\
\hline 4-Methyl-2-pentanone & & 1 & -- & -- & 140 & MW-32S \\
\hline m,p-Xylene & & 1 & 10 & 0 & $0.94 \mathrm{~J}$ & MW-32S \\
\hline
\end{tabular}




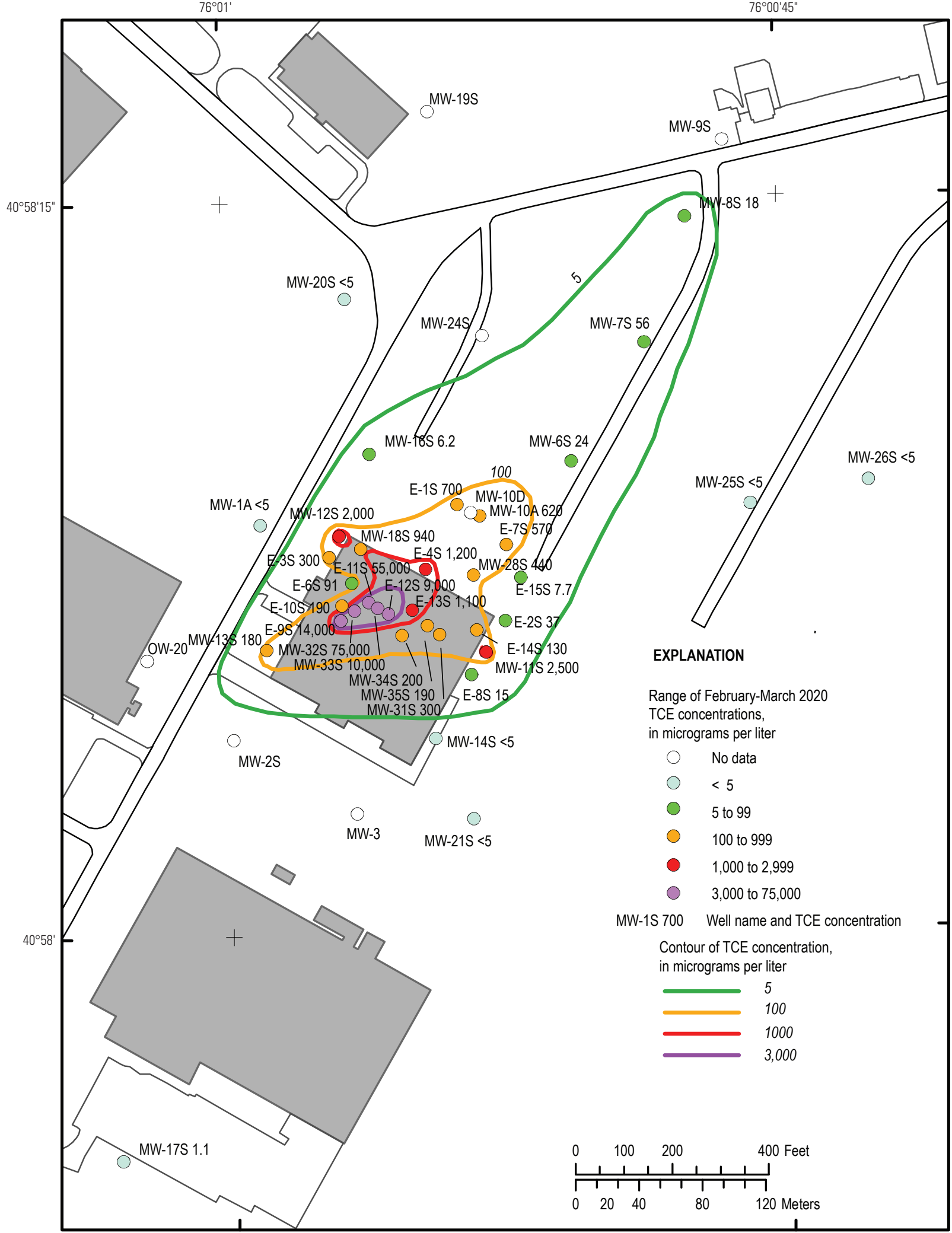

Figure 19. Trichloroethene (TCE) concentrations in February-March 2020 groundwater samples and contoured TCE groundwater concentrations for wells with depths to bottom of open interval less than 60 feet below land surface, Valmont TCE Superfund Site, Luzerne County, Pennsylvania. Contours are approximate. Data from U.S. Environmental Protection Agency (2020a). 


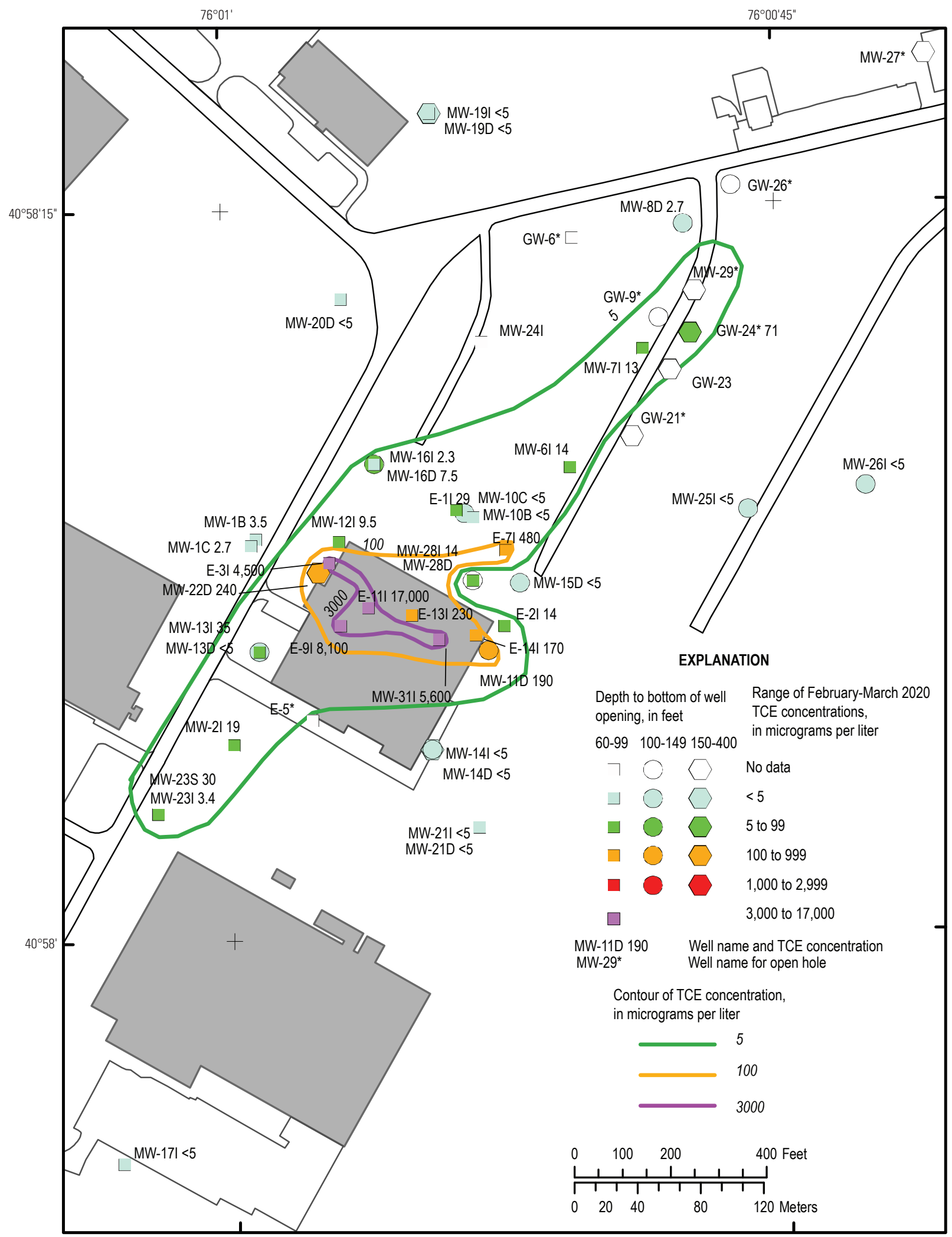

Figure 20. Trichloroethene (TCE) concentrations in February-March 2020 groundwater samples and contoured TCE groundwater concentrations for wells with depths to bottom of open interval greater than or equal to 60 feet (ft) below land surface, with different symbols for ranges of bottom depth (60-99 ft; 100-149 ft; 150-400 ft), Valmont TCE Superfund Site, Luzerne County, Pennsylvania. Contours are approximate and primarily based on data from wells open from depths ranging from 60 to $100 \mathrm{ft}$. Data from the U.S. Environmental Protection Agency (2020a). 
E-12S, E-9I, MW-31I and E-3I, and range from 4,500 to $75,000 \mu \mathrm{g} / \mathrm{L}$ (table 3). The deepest sampled interval with TCE concentrations greater than 3,000 $\mu \mathrm{g} / \mathrm{L}$ is MW-31I (sample had $5,600 \mu \mathrm{g} / \mathrm{L}$ ), which has a screened interval open from 69 to $79 \mathrm{ft}$ bls.

TCE concentrations were included on the same cross sections as the water level measurements and potentiometric surfaces. Well open-intervals on these sections were colorcoded according to the TCE concentration sampled in that well in February-March 2020, if available. No contouring of TCE concentrations was included on cross sections.

TCE concentrations on sections B-B' (plate 13), E-E' (plate 16), and G-G' (plate 9) and map views (figs. 19 and 20) indicate that the northeast direction of migration of TCE in groundwater flow from sources within the former Chromatex Plant is dominant over the west or northwest direction. MW-6 is the only well cluster on section G-G' (plate 9) that contains detectable TCE concentrations. Potentiometric head gradients indicate potential flow toward the northwest on this section assuming isotropic aquifer conditions (plate 9), but no detectable TCE downgradient (northwest) of MW-6 indicates that TCE preferentially flowed downdip to the northeast with pathways partly controlled by the orientation of bedding and associated water-bearing zones. Well MW-6 (an open hole later reconstructed as MW-6S and MW-6I) is also included on section B-B' (plate 13), which is aligned in, and shows the downgradient detectable TCE concentrations, a northeast direction. Section B-B' therefore most closely follows the main direction of TCE migration than the other cross sections.

Along section $\mathrm{C}-\mathrm{C}^{\prime}$ (plate 15), where the highest hydraulic heads are present at the base of the hill (figs. 1, 5A, 16-18), a secondary TCE source was reported near the MW-11S location (U.S. Environmental Protection Agency, 2015), which is the probable source of the high TCE concentrations in that area. The elevated TCE concentrations in nearby well MW-31I may be from the secondary source area near MW-11S or possibly, but less likely, have migrated from the primary TCE shallow sources near wells E-11S and E-12S, which have higher heads than MW-31S, as shown on section E-E' (plate 16).

Both fracturing and brecciation occur in well E-5 where the fault zone intersects the borehole, features which would have opposing effects by either acting as potential conduits or barriers, respectively, to groundwater flow. Groundwater flow through the weathered zone (such as was noted during the drilling of well MW-13I) that could be connected to the fault may be responsible for TCE concentrations detected across the divide and southwest of the fault in wells MW2I and MW-23S (section A-A', plate 11). Section C-C' (plate 15) occurs north of this divide, and water levels in wells on this section also indicate an overall flow direction toward the northeast.

Elevated TCE concentrations along the northwest edge of the former Chromatex Plant in wells E-3I and MW-12S depicted on section A-A' (plates 11 and 12, figs. 19 and 20) are downgradient but up-dip of primary sources inside the former Chromatex Plant, as shown on section E-E' (plate 16). Although the main direction of TCE migration in groundwater from sources within the former Chromatex Plant appear to be to the northeast, TCE has also moved from these sources to the northwest, to at least the vicinity of wells E-3I and MW-12S.

Anomalies occur in the TCE concentrations, including large apparent differences in concentrations among closely spaced open intervals in wells. For example, E-6S on section E-E' (plate 16) had a TCE concentration of $91 \mu \mathrm{g} / \mathrm{L}$ but is located only about $50 \mathrm{ft}$ downgradient from E-11S, where the concentration was $55,000 \mu \mathrm{g} / \mathrm{L}$. Head gradients on E-E' also indicate potential flow from MW-31I to E-13I, but the TCE concentrations in those wells were 5,600 and $230 \mu \mathrm{g} / \mathrm{L}$, respectively. Such differences can be explained by different contributing fractures in each well's open interval, complex flow paths, and (or) cross contamination between intervals in the aquifer related to the long period of time the boreholes remained as open holes prior to reconstruction as screened monitor wells (for example, the E series wells were originally drilled to depths of 100 to $150 \mathrm{ft}$ bls before being reconstructed from 2 to 7 years later) (Tetra Tech NUS, Inc., 2010, 2011, 2014, 2016). The water-bearing zones for E-13I and MW-31I, as indicated by logs shown in appendix figures 1.11 and 1.13, respectively, appear to be near the bottom and top of a correlated shale unit (plate 16), across which flow may be restricted. Well MW-22D is the deepest well in this study and is open to the Mauch Chunk Formation, but the TCE concentration of $240 \mu \mathrm{g} / \mathrm{L}$ in the 2020 water sample from the reconstructed well (screen depth 294-304 ft bls) likely resulted from its history as a production well with a much longer open interval. A water-bearing zone present in well MW-22 (formerly PW-1) at a depth of about $57 \mathrm{ft}$ bls (figure 14E), similar to intervals in nearby wells E-3I and M12-S that have elevated TCE concentrations (table 3 ), was reported to produce at least 1 gallon per minute (gal/min) when logged (appendix 1, figure 1.20), which flowed down and out a water bearing zone near $300 \mathrm{ft}$ bls, where MW-22D is screened; this downward flow pattern may have resulted in the transport of TCE from fractures near $57 \mathrm{ft}$ bls to fractures near $300 \mathrm{ft}$ bls when the borehole was open and pumped as a production well.

Of the PFAS analyzed in groundwater samples collected from 51 wells in 2020, 8 of 12 compounds determined by EPA Method 537 were detected (table 5; U.S. Environmental Protection Agency, 2020b). PFOS and PFOA were the most frequently detected compounds, measured in more than half of the 51 samples collected in 2020 and in concentrations of as much as $969 \mathrm{ng} / \mathrm{L}$ for PFOS, 1,390 ng/L for PFOA, and 2,539 ng/L for combined PFOS and PFOA (table 5). Previous sampling in 2018 indicated higher PFAS concentrations in groundwater from well MW-32S than reported in groundwater from other wells sampled in 2020 (which did not include MW-32S); the 2018 groundwater sample from well MW-32S had $974 \mathrm{ng} / \mathrm{L}$ for PFOS, 4,270 ng/L for PFOA, and 5,244 ng/L for combined PFOS and PFOA (table 5; U.S. Environmental Protection Agency, 2018b). The EPA has established HA levels in drinking water only for PFOS and PFOA (U.S. Environmental Protection Agency, 2016b) in the PFAS-class of compounds included in analyses of Site groundwater 
Table 5. Maximum concentrations reported for per- and polyfluoroalkyl substances (PFAS) detected in analyses of groundwater samples collected from 51 wells from February 16 to March 3, 2020, at Valmont TCE Site, Superfund Luzerne County, Pennsylvania. Data from U.S. Environmental Protection Agency (2020b).

[HA, Health Advisory level for drinking water; ng/L, nanograms per liter; --, no data or not applicable; U, undetected]

\begin{tabular}{|c|c|c|c|c|c|c|}
\hline Compound & $\begin{array}{l}\text { Number of } 2020 \\
\text { samples with } \\
\text { detection }\end{array}$ & $\begin{array}{c}\mathrm{HA}^{1} \text {, } \\
\text { in } \mathrm{ng} / \mathrm{L}\end{array}$ & $\begin{array}{c}\text { Number of } \\
\text { wells with } \\
\text { concentration } \\
\text { greater than HA }\end{array}$ & $\begin{array}{l}\text { Maximum } \\
\text { concentration, } \\
\text { in } \mathrm{ng} / \mathrm{L}\end{array}$ & $\begin{array}{l}\text { Well with } \\
\text { maximum } \\
\text { concentration }\end{array}$ & $\begin{array}{c}2018 \\
\text { concentration } \\
\text { in MW-32S, } \\
\text { in } \mathrm{ng} / \mathrm{L}\end{array}$ \\
\hline \multicolumn{7}{|c|}{ PFAS with HA levels } \\
\hline PFOS (perfluorooctanesulfonic acid) & 28 & 70 & 13 & 969 & E-11S & 974 \\
\hline PFOA (perfluorooctanoic acid) & 28 & 70 & 11 & 1,390 & E-11S & 4,270 \\
\hline PFOS plus PFOA & 30 & 70 & 14 & 2,539 & E-11S & 5,244 \\
\hline \multicolumn{7}{|c|}{ PFAS without HA levels } \\
\hline PFHxA (perfluorohexanoic acid) & 24 & -- & -- & 1,330 & E-11S & 4,190 \\
\hline PFBS (perfluorobutanesulfonic acid) & 22 & -- & -- & 478 & E-11S & 504 \\
\hline PFHxS (perfluorohexanesulfonic acid) & 21 & -- & -- & 251 & E-11S & 440 \\
\hline PFHpA (perfluoroheptanoic acid) & 14 & -- & -- & 459 & E-11S & 1,530 \\
\hline PFNA (perfluorononanoic acid) & 4 & -- & -- & 24.4 & E-11S & 130 \\
\hline PFUnA (perfluoroundecanoic acid) & 2 & -- & -- & 17.6 & E-11I & 18.7 \\
\hline PFDA (perfluorodecanoic acid) & 0 & -- & -- & -- & -- & 42.6 \\
\hline PFDoA (perfluorododecanoic acid) & 0 & -- & -- & -- & -- & $\mathrm{U}$ \\
\hline PFTA (perfluorotetradecanoic acid) & 0 & -- & -- & -- & -- & U \\
\hline PFTrDA (perfluorotridecanoic acid) & 0 & -- & -- & -- & -- & $\mathrm{U}$ \\
\hline N-MeFOSAA ${ }^{2}$ & 0 & -- & -- & -- & -- & 10.2 \\
\hline N-EtFOSAA ${ }^{3}$ & 0 & -- & -- & -- & -- & $\mathrm{U}$ \\
\hline
\end{tabular}

${ }^{1}$ Lifetime health advisory for drinking water from U.S. Environmental Protection Agency (2016b).

${ }^{2} \mathrm{~N}$-methyl perfluorooctane sulfonamido acetic acid.

${ }^{3} \mathrm{~N}$-ethyl perfluorooctane sulfonamido acetic acid.

samples, and concentrations were higher than the lifetime HA of $70 \mathrm{ng} / \mathrm{L}$ for combined PFOS and PFOA in samples from 14 of 51 wells. For the 26 samples in which both PFOS and PFOA were reported as detected, the median ratio of PFOA to PFOS concentration was about 0.92 and ranged from 0.20 (well E-6S) to 7.21 (well MW-III) (table 3). Thus, there is a wide range of relative concentrations of PFOA and PFOS in groundwater samples at the Valmont TCE Superfund Site, possibly indicating variability in the formulation of sources of PFAS used at the site. Three other PFAS compounds were detected in more than 20 of the 51 samples and measured in concentrations of as much as $1,330 \mathrm{ng} / \mathrm{L}$ for PFHxA (perfluorohexanoic acid), $478 \mathrm{ng} / \mathrm{L}$ for PFBS (perfluorobutanesulfonic acid), and $251 \mathrm{ng} / \mathrm{L}$ for PFHxS (perfluorohexanesulfonic acid) (tables 3 and 5). PFHpA (perfluoroheptanoic acid) was detected in 14 of 51 samples and measured in concentrations of as much as $469 \mathrm{ng} / \mathrm{L}$ and two others compounds, PFNA (perfluorononanoic acid) and PFUnA (perfluoroundecanoic acid) were detected in a few (2 to 4) samples at relatively low concentrations (less than $25 \mathrm{ng} / \mathrm{L}$ ).
The February-March 2020 combined PFOS and PFOA concentrations are plotted on plan-view maps (figs. 21 and 22). Earlier data from 2016 or 2018 data for a few wells (table 3) that were not sampled in 2020 are included in the maps (figs. 21 and 22) for more complete spatial distribution of combined PFOS and PFOA concentrations, but these earlier data (labeled by year) may not represent 2020 conditions and should be interpreted with caution. The earlier data indicate that the 2018 sample from well MW-32S had the highest overall combined PFOS and PFOA concentrations of 5,255 ng/L (table 3). The 2020 data indicate that the highest combined PFOS and PFOA concentrations appear to extend from the probable source area in the former Chromatex Plant near well E-11S, where the highest 2020 combined concentration of 2,539 $\mathrm{ng} / \mathrm{L}$ was measured, to the northeast on the plan-view map, clustering in wells along Bent Pine Road, similar to the distribution of TCE concentrations. Elevated combined PFOA and PFOS concentrations (ranging from about 500 to $800 \mathrm{ng} / \mathrm{L}$ ) also were measured in 2020 groundwater samples from wells near but to 


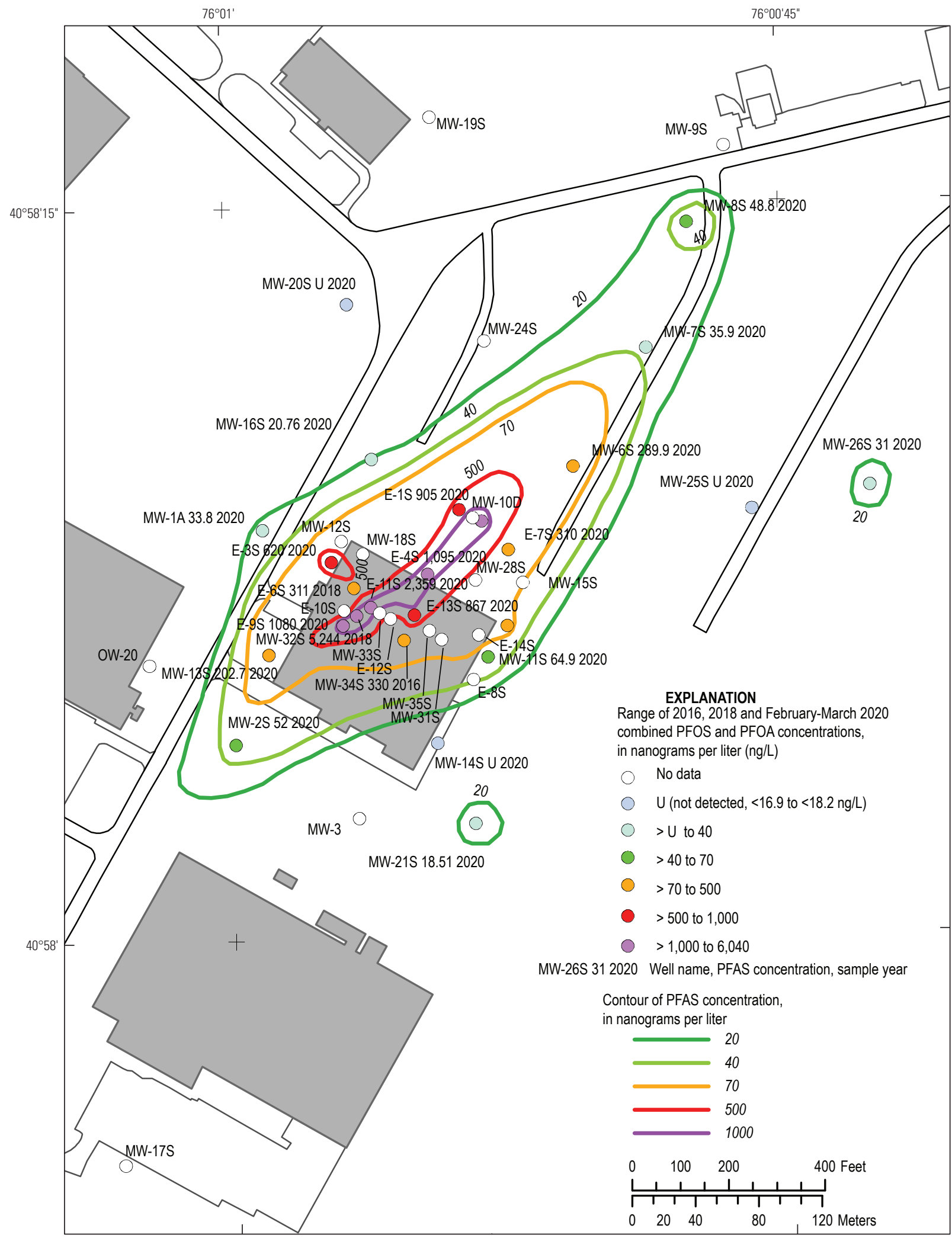

Figure 21. Combined perfluorooctanoic acid (PFOA) and perfluorooctanesulfonic acid (PFOS) concentrations in 2016, 2018, and February-March 2020 groundwater samples and contoured combined PFOA and PFOS (PFAS) groundwater concentrations in wells with depths to bottom of open interval less than 60 feet, Valmont TCE Superfund Site, Luzerne County, Pennsylvania. Contours are approximate. Data from U.S. Environmental Protection Agency (2020b). 


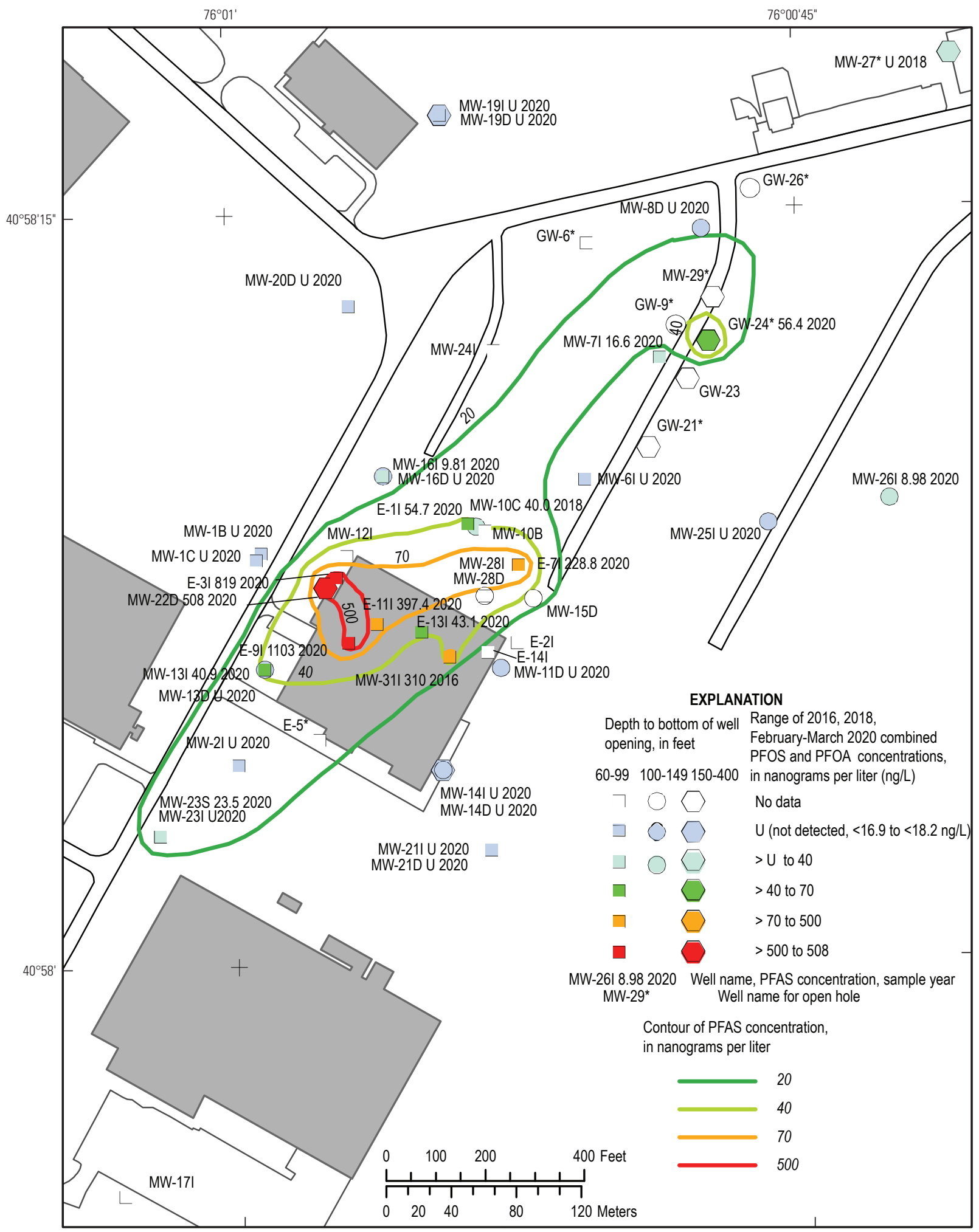

Figure 22. Combined perfluorooctanoic acid (PFOA) and perfluorooctanesulfonic acid (PFOS) concentrations in 2016, 2018, and February-March 2020 groundwater samples and contoured combined PFOA and PFOS (PFAS) groundwater concentrations for wells with depths to bottom of open interval greater than or equal to $60 \mathrm{feet}$ (ft) below land surface, with different symbols for ranges of bottom depth (60-99 ft; 100-149 ft; 150-400 ft), Valmont TCE Superfund Site, Luzerne County, Pennsylvania. Contours are approximate and primarily based on data from wells open from depths ranging from 60 to 100 ft. Data from U.S. Environmental Protection Agency (2020b). 
the northwest of the former Chromatex Plant, including shallow to intermediate depth wells E-3S and E-3I and deep well MW-22D (table 3; figs. 19 and 20).

\section{Discussion of Hydrogeologic Framework, Water Levels, and Contaminant Distribution}

The cross sections presenting lithologic correlations from available geophysical logs show alternating intervals of relatively elevated and reduced natural gamma activity, which correspond to changes in lithology (shale and sandstone/conglomerate, respectively), with water-bearing zones and well screens commonly located at lithologic contacts, sometimes near thin coal seams. The log correlations indicate that bedding in the north-central part of the study area generally strikes east-northeast and dips to the southeast, in general agreement with the mapped regional geologic structure in the area that shows the northeast-trending axes of an anticline to the northwest and a syncline to the southeast of the former Chromatex Plant. Discontinuities in log correlations and structural features apparent on borehole video logs (large changes in bedding orientations, intensely fractured zones) indicate several faults (possibly thrust faults) may be present along the southeastern part of the study area. Wells more than $200 \mathrm{ft}$ in depth penetrate the underlying Mauch Chunk Formation, as interpreted from an increase in natural gamma activity.

The development of cross sections and review of borehole geophysical and video logs indicate water-bearing zones located at lithologic contacts generally are parallel to bedding. An aquifer test of well E-2S indicates the strongest hydraulic connection with nearby well E-14S, completed at a similar depth interval (Tetra Tech NUS, Inc., 2017), such that drawdown appears to show a hydraulic connection along a bedding plane; the aquifer test may also indicate a hydraulic discontinuity possibly related to faulting in the area, as water levels in well MW-31S showed little response to pumping nearby well E-2S.

Advective transport of TCE likely follows groundwater flow through fractures or bedding-plane partings that occur near or along the contacts between lithologies, including contacts on the top of shale beds, indicated by relatively highgamma logs where coal, impure coal, or carbonaceous shale may be present. Flow also occurs through fractures developed in response to faulting or stress fields that have orientations that differ from bedding. Other factors affecting transport of TCE in the groundwater system may include density-driven migration along bedding planes or other fracture openings. Groundwater flow potential and detectable TCE concentrations along or near the relatively high-gamma shale beds is indicated on most cross sections (plates 9, 11-17), but considering most well open intervals included these preferential flow features (they were constructed within or across contacts with these beds), this observation is biased toward the locations where the data were collected. Many relatively high-gamma shale beds that potentially could transport and (or) sorb high concentrations of TCE in groundwater near the former Chromatex Plant are not intersected by open intervals in wells in areas that are hydraulically downgradient, and thus no data are available to show possible TCE migration in the groundwater-flow paths along or near those beds. Thus, there may be fractures aligned with beds that are associated with migration or elevated concentrations of TCE in groundwater that have not been identified. For example, wells E-3S and MW-12S, which had 4,500 and 2,000 $\mu \mathrm{g} / \mathrm{L}$ TCE, respectively, are screened in the same relatively high-gamma unit; about $120 \mathrm{ft}$ downgradient toward the MW-16 cluster, this unit as correlated occurs between the open intervals of MW16S (open 30-45 ft bls; $6.2 \mu \mathrm{g} / \mathrm{L} \mathrm{TCE}$ ) and MW-16I (open $66-86 \mathrm{ft}$ bls; $2.3 \mu \mathrm{g} / \mathrm{L} \mathrm{TCE}$ ) with the top of the unit at about $47 \mathrm{ft}$ bls (fig. 15B) and the unit does not intersect another well until MW-19S another $800 \mathrm{ft}$ away (section A-A', plate 11).

Zones of low permeability and (or) lack of hydraulic connections through fractures may limit contamination migration in the fractured bedrock aquifer at the Site. For example, TCE concentrations were lower by as much as three orders of magnitude (91 and $190 \mu \mathrm{g} / \mathrm{L}$, respectively) in samples from wells E-6S and E-10S than in samples from nearby wells E-11S and MW-32, which had the highest sitewide TCE concentrations in $2020(55,000$ and $75,000 \mu \mathrm{g} / \mathrm{L}$, respectively). TCE concentrations in groundwater greater than about $10,000 \mu \mathrm{g} / \mathrm{L}$ (about 1 percent of TCE solubility in water) may indicate the presence of a dense nonaqueous phase liquid (DNAPL) (U.S. Environmental Protection Agency, 1993). Wells E-10S and E-6 are approximately along strike or slightly up-dip of, and have similar hydraulic heads or are slightly downgradient from, well MW-11S and MW-32S, but are screened in slightly different sections of the aquifer (plates 14 and 16) which appear to have no or few fractures, as indicated by the geophysical logs (appendix 1 figures 1.6 and 1.9), that would connect these wells to the TCE source area. A 2017 aquifer test of well E-11I that was adversely affected by precipitation nevertheless indicated that the interval spanned by well E-11I was low yielding, having a drawdown of $37 \mathrm{ft}$ while pumping at about $1 \mathrm{gal} / \mathrm{min}$ (Tetra Tech NUS, Inc., 2017).

The depths to weathered and competent bedrock appear to vary across the Site. In areas where weathered bedrock extends to relatively greater depths below land surface, such as near MW-32S and E-9 (table 2) that are proximate to the source area in the former Chromatex Plant, the higher porosity and lower permeability typical of weathered bedrock compared to unweathered (competent) bedrock could potentially result in the weathered material acting as a sink and subsequent source (reservoir) of TCE and other contamination, as was noted in the 2015 optimization report (U.S. Environmental Protection Agency, 2015). Analyses of rock samples from the E-2 core evaluated for matrix diffusion properties indicated that TCE concentrations were highest in porewater associated with weathered zones near fractures, especially for shallow fractures at depths less than $26 \mathrm{ft} \mathrm{bls}$ (Tetra Tech NUS, Inc., 2010). 


\section{Limitations and Data Gaps}

Limitations of this study include the assumptions that available logs for deep wells could be used to represent lithology for nearby shallow wells and that log correlations could be extended from well to well over distances of several hundred feet. Thus, the correlations should be considered generalized. Further refinement of the relation between observed lithologies as (indicated on video or ATV logs, or as reported on drillers' logs) and other geophysical logs (gamma, resistivity) could be done with available logs, but many wells do not have a common suite of logs to complete this analysis (for example, some wells do not have video, ATV, or density logs). Variation in different geologists' description of drill cuttings collected during different periods introduces additional uncertainty to consider in use of the drillers' logs to identify lithology, and a formal review of these variations was not done for this study. Other limitations include assumptions about contouring waterlevels and contaminant concentrations for wells intervals completed at different depths. Evaluation of groundwater concentrations of metals, other PFAS, and other VOCs (such as 1,1,1-TCA) were not completed as part of this preliminary study but may help provide more information about pathways of contamination.

The evaluation of changes in TCE concentrations between samples collected in 2016 and 2020 also was not completed as part of this preliminary study, but changes in concentrations through time may provide information about contaminant migration. However, as the E-series wells were open holes for several years before being reconstructed and subsequently sampled in 2016, the 2016 groundwater concentrations could have been affected by cross-borehole contamination from shallow zones to deeper zones in the presence of downward vertical gradients and thus may be difficult to interpret. The largest differences between 2016 and 2020 TCE concentrations were in samples from wells at or near the TCE source area in the former Chromatex Plant. TCE concentrations decreased from 2016 to 2020 in samples from shallow wells E-11S (195,000 to 55,000 $\mu \mathrm{g} / \mathrm{L}), \mathrm{MW}-32$ (150,000 to $75,000 \mu \mathrm{g} / \mathrm{L}), \mathrm{MW}-33$ (28,000 to $10,000 \mu \mathrm{g} / \mathrm{L}), \mathrm{E}-13 \mathrm{~S}(6,500$ to $1,100 \mu \mathrm{g} / \mathrm{L})$, and intermediate depth wells E-11I $(66,000$ to $17,000 \mu \mathrm{g} / \mathrm{L})$ and E-13I $(4,400$ to $230 \mu \mathrm{g} / \mathrm{L})$ (Tetra Tech NUS, Inc., 2016; U.S. Environmental Protection Agency, 2020a). TCE concentrations increased from 2016 to 2020 in samples from wells E-9S (970 to $14,000 \mu \mathrm{g} / \mathrm{L}$ ), E-12S (190 to 9,000 $\mu \mathrm{g} / \mathrm{L}), \mathrm{E}-9 \mathrm{I}(3,600$ to $8,100 \mu \mathrm{g} / \mathrm{L})$, and MW-12S (190 to $2,000 \mu \mathrm{g} / \mathrm{L})($ Tetra Tech NUS, Inc., 2016; U.S. Environmental Protection Agency, 2020a).

Data gaps include, but are not limited to, incomplete, insufficient, or missing information to determine

- the location of apparent faults, folds, and other structural features, their hydraulic properties, and effect on groundwater flow and contaminant migration;

- the role of weathered rock and overburden in the aquifer as source reservoirs for contaminants;
- the role of organic-rich zones in the aquifer as potential sinks for contaminants;

- the role of water-level fluctuations in contaminant migration or possible seasonality in contaminant concentrations;

- the water-bearing properties of intervals within the aquifer;

- the distribution of TCE and contaminants at depth-for example, TCE concentrations are $240 \mu \mathrm{g} / \mathrm{L}$ in a 294- to 304-ft-deep interval in the Mauch Chunk Formation in $\mathrm{MW}-22 \mathrm{D}$;

- the distribution of TCE and contaminants in shallow to intermediate depths - for example, new monitoring intervals might be located where no data are available but there is potential for migration;

- the possible presence of TCE as DNAPL and pathways for DNAPL migration;

- the distribution of PFAS in general-for example, fewer data are available for PFAS than VOCs;

- the role of open holes as conduits for cross contamination in the aquifer-for example, wells E-5, MW-29, and MW-27 that have open intervals with depths of 150,250 , and $400 \mathrm{ft}$;

- the effects of any nearby pumping on contamination migration; and

- the discharge locations (wells or streams) for groundwater containing TCE and PFAS from the source area at the Valmont TCE Superfund Site.

\section{Summary}

The Valmont TCE Superfund Site, Luzerne County, Pennsylvania is underlain by fractured and folded sandstones and shales of the Pottsville and Mauch Chunk Formations that form a fractured-rock aquifer recharged locally by precipitation. Industrial activities at the former Chromatex Plant (Plant) resulted in trichloroethene (TCE) contamination of groundwater at and near the facility, which was identified in 1987 and led to listing as a Superfund site by U.S. Environmental Protection Agency (EPA) in 1989. To address the problem of TCE concentrations in nearby residential wells exceeding the maximum contaminant level (MCL) of 5 micrograms per liter $(\mu \mathrm{g} / \mathrm{L})$, alternate water supplies were provided. Initial characterization and subsequent remediation by the EPA resulted in identifying the need for an updated understanding of the complex hydrogeology and conceptual site model in 2015. Other contaminants present in groundwater at the site include per- and polyfluoroalkyl substances (PFAS).

In response to a request from the EPA in 2019, the U.S. Geological Survey (USGS) prepared cross sections and maps to provide more information about the hydrogeologic 
framework at and near the site, and to assist in improving the conceptual site model using water level and contaminant data collected by the EPA in 2020. For this effort, available geophysical and borehole video logs collected in open holes from 2002 to 2014 were compiled for 44 wells ranging in depth from 76 to 400 feet (ft) below land surface (bls) to develop the cross sections. Geophysical logs used for lithologic correlation included natural gamma, single-point resistance, density, optical televiewer (OTV), and acoustic teleview logs (ATV). Borehole video logs were used to provide information about lithology, structural features, and water-bearing zones.

The cross sections presenting lithologic correlations from available geophysical logs show alternating intervals of relatively elevated and reduced natural gamma activity that correspond to changes in lithology, with water-bearing zones and well screens commonly located at lithologic contacts between fine-grained (shale) and coarser-grained (sandstone, conglomerate) units, and sometimes near thin coal seams that are present at the top of fining upward sequences (shale). Other water-bearing zones that are not aligned near lithologic contacts includes fracture zones associated with faulting, but video logs indicate that few water-bearing fractures appear to occur within the massive sandstone and conglomerate beds. Available limited aquifer testing indicates relatively low permeability for borehole intervals tested within the former Chromatex Plant. The geophysical log correlations indicate that bedding in the north-central part of the study area, which extends from the Plant northeast toward Bent Pine Road, generally strikes east-northeast and dips to the southeast, in general agreement with mapped regional geologic structure in the area that shows the northeast-trending axes of an anticline to the northwest and a syncline to the southeast of the former Chromatex Plant. Discontinuities in log correlations and structural features apparent on borehole video logs (large changes in bedding orientations, intensely fractured zones) indicate several faults (possibly thrust faults) may be present along the southeastern part of the study area. Boreholes more than $200 \mathrm{ft}$ in depth penetrate the underlying Mauch Chunk Formation, as interpreted from an increase in natural gamma activity relative to the overlying Pottsville Formation.

The March 2020 water-level data shown on cross sections and maps indicate large downward vertical hydraulic gradients (greater than about $8 \mathrm{ft}$ between closely spaced wells of different depths) and radial hydraulic gradients that extend laterally from the Site to the northeast, northwest, and southwest, generally following topography. Complex geologic structure and fracture distribution and orientation may affect groundwaterflow directions locally, such that flow directions cannot be estimated solely on the basis of hydraulic gradients. Depth to water in wells measured in March 2020 ranged from about 4 to $70 \mathrm{ft}$ bls and was shallowest (least) along the southeastern part of the study area at the edge of the Plant adjacent to the large hill that is upgradient from the site. The depth to water was greatest (and water-level altitudes were lowest) in the deepest screened intervals on the site, which are completed in the Mauch Chunk Formation. Steep vertical gradients indicate low permeability in competent, unfractured bedrock between water-bearing intervals in the aquifer; sections of competent, unfractured bedrock appear to generally correspond to sandstone and conglomerate lithologies and water-bearing zones tend to occur at lithologic contacts between shale or coal/shale and adjacent sandstone and conglomerate.

Samples collected during February-March 2020 indicate that TCE is the most widespread volatile organic compound (VOC) of those analyzed; it was detected in water from 55 of 75 wells sampled and in levels above the drinking water standard $(5 \mu \mathrm{g} / \mathrm{L})$ in water from 49 of the 75 wells. TCE also is present at the highest concentrations of VOCs analyzed. The recent (February-March 2020) data for TCE groundwater concentration shown on cross sections and maps indicate highest TCE concentrations (greater than 3,000 $\mu \mathrm{g} / \mathrm{L}$ and as much as $75,000 \mu \mathrm{g} / \mathrm{L}$ ) are from shallow (less than 60 feet [ft] below land surface [bls]) and intermediate depth (60 to $100 \mathrm{ft}$ bls) wells near the center of the former Chromatex Plant, where the primary source of contamination has been identified. Combined concentrations of perfluorooctanoic acid (PFOA) and perfluorooctanesulfonic acid (PFOS) were greater than the health advisory (HA) of 70 nanograms per liter (ng/L) in 14 of 51 wells sampled during February-March 2020, and the highest 2020 combined PFOA and PFOS concentration of $2,539 \mathrm{ng} / \mathrm{L}$ was in a sample from a shallow well (34-ft-deep E-11S) near the TCE source area. TCE and PFAS (as combined PFOA and PFOS) contamination is present at depths as much as $304 \mathrm{ft}$ bls near the former Chromatex Plant, with concentrations of about $240 \mu \mathrm{g} / \mathrm{L}$ and $508 \mathrm{ng} / \mathrm{L}$, respectively in samples from one well. The 2020 data also indicate that TCE and PFAS concentrations exceeding drinking-water MCL or HA levels are present in groundwater at depths less than $200 \mathrm{ft}$, and extend predominantly in a northeast direction from the former Chromatex Plant, apparently influenced by, and consistent with what is known about, hydraulic gradients, aquifer properties related to lithology, and geologic structure. Although, the principal path of TCE (and PFAS) migration in groundwater appears to be toward the northeast at the depths of monitor wells (less than $200 \mathrm{ft}$ ), the presence of elevated TCE (concentrations of 2,000 to $4,500 \mu \mathrm{g} / \mathrm{L}$ ) in groundwater from intervals about $60 \mathrm{ft}$ bls in wells MW12S and E3I near, but to the northwest of the former Chromatex Plant, indicate other potential sources or directions and pathways of contaminant migration that cannot be determined from available data. Additionally, little data are available to determine the direction of possible migration for elevated TCE $(240 \mu \mathrm{g} / \mathrm{L})$ in groundwater in a deep (screened from 294 to $304 \mathrm{ft}$ bls) monitor well (MW-22) reconstructed from a former production well along the northwest side of the Plant. Other possible factors that may affect the apparent distribution of contamination may include sorption and storage in weathered bedrock (as was indicated by data from a matrix diffusion study of core from borehole E-2), sorption within organic-rich shales and (or) bony coals, faults and other discontinuities, the lateral extent of waterbearing zones, and water-level fluctuations. 


\section{References Cited}

Berg, T.M., Edmunds, W.E., Geyer, A.R., and others, 1980, Geologic map of Pennsylvania: Pennsylvania Bureau of Topographic and Geologic Survey, 2 plates, 1:250,000 scale, accessed September 2, 2020, at http://elibrary.denr.pa.gov/ GetDocument?docId=1751215\&DocName=Map1_Geo_Pa.

Burton, W.C., Plummer, L.N., Busenberg, E., Lindsey, B.D., and Gburek, W.J., 2002, Influence of fracture anisotropy on ground water ages and chemistry, Valley and Ridge province, Pennsylvania: Ground Water, v. 40, no. 3, p. 242-257, accessed July 23, 2021, at https://doi.org/10.1111/ j.1745-6584.2002.tb02652.x.

Edmunds, W.E., 1997, The Pottsville Formation in the Lackawanna Synclinorium in Inners, J.D., ed., Guidebook for 62nd annual field conference of Pennsylvania Geologists 1997, Geology of the Wyoming-Lackawanna Valley and its mountain rim, northeastern Pennsylvania: Harrisburg, Pa., Field Conference of Pennsylvania Geologist, Inc., 1997 Guidebook, p. 24-27, accessed February 2021 at https://www.fcopg.org/download-guidebooks.

Edmunds, W.E., and Gillmeister, N.W., 1997, Stop 2, PA 309 Roadcut at Luzerne- Mauch-Chunk-Pottsville stratigraphy and structure, in Inners, J.D., ed., Guidebook for 62nd annual field conference of Pennsylvania Geologists 1997, Geology of the Wyoming-Lackawanna Valley and its mountain rim, northeastern Pennsylvania: Harrisburg, Pa., Field Conference of Pennsylvania Geologist, Inc., 1997 Guidebook, p. 87-94, accessed February 2021 at https://www.fcopg.org/download-guidebooks.

Evans, M.A., and Sale, G., 2015, Regional fracture systems in the Pennsylvania Valley and Ridge Province, a record of Alleghenian stress direction [abs.]: Geological Society of America Abstracts with Programs, v. 47, no. 3, p. 89, accessed July 23, 2021, at https://gsa.confex.com/gsa/ 2015NE/webprogram/Paper252409.html.

International Exploration, Inc., 1989, Chromatex Plant No. 2, West Hazleton, PA Extent of groundwater contamination study phase 1: Report prepared for Chromatex, Inc., variously paginated, accessed July 2021 at https://semspub.epa.gov/work/03/449901.pdf.

Keys, W.S., 1990, Borehole geophysics applied to groundwater investigations: U.S. Geological Survey Techniques of Water-Resources Investigations 02-E2, 150 p., accessed August 2021 at https://doi.org/10.3133/twri02E2.

Lohman, S.W., 1937, Ground water in northeastern Pennsylvania: Pennsylvania Geological Survey, 4th ser., Bulletin W4, 312 p., 1 plate, 1:380,160 scale, accessed February 2021 at http://elibrary.denr.pa.gov/GetDocument? docId $=1751875 \&$ DocName=W4_GW_NEPa.
Newport, T.G., 1977, Summary ground-water resources of Luzerne County, Pennsylvania: Pennsylvania Geological Survey, 4th ser., Water Resource Report 40, 63 p., 1 plate, 1:125,000 scale, accessed February 2021 at http://elibrary.denr.pa.gov/GetDocument?docId= 1751911\&DocName=W40_GWRes_LuzerneCo.

Pennsylvania Geological Survey, 2008a, Physiographic provinces: Pennsylvania Department of Conservation and Natural Resources web page, vector digital data, accessed January 2021 at https://www.pasda.psu.edu/uci/ FullMetadataDisplay.aspx?file=pags_physprov2008.xml.

Pennsylvania Geological Survey, 2008b, Physiographic sections: Pennsylvania Department of Conservation and Natural Resources web page, vector digital data, accessed January 2021 at https://www.pasda.psu.edu/uci/ FullMetadataDisplay.aspx?file=pags_physsections2008.xml.

Pennsylvania Spatial Data Access, 2015, Mosaics of PAMAP DEMs by PAMAP Lidar Delivery Zones, raster digital elevation model, resolution 1 meter (3.2 feet), county mosaic for Luzerne County: Pennsylvania Spatial Data Access web page, accessed March 2021 at https:/www.pasda.psu.edu/download/pamap/LidarMosaics/ CountyMosaics/county_DEM_1M/.

Pennsylvania Spatial Data Access, 2016, PAMAP_Hillshade: Pennsylvania Spatial Data Access web page, digital raster data, accessed March 2021 at https://imagery.pasda.psu.edu/arcgis/rest/services/pasda/ PAMAP_Hillshade/MapServer.

Reese, S.O., 2016, Outstanding geologic feature of Pennsylvania-Spring Mountain thrust fault, Schuylkill County: Pennsylvania Geological Survey, 4th ser., Trail of Geology Series TG 16-102.0, accessed March 2021 at http://elibrary.denr.pa.gov/ GetDocument?docId=1751847\&DocName= TG16-102_GeoFeat_SpringMtnThrustFault_SchulykillCo.

Schasse, H.W., MacLauchlan, D.B., and Inners, J.D., 2012, Bedrock geology and coal resources of the Conyngham quadrangle, Luzerne and Schuylkill Counties, Pennsylvania: Pennsylvania Geological Survey, 4th ser., Atlas 175b, 2 pls., 1:24,000 and 1:12,000 scale, accessed October 5, 2020, at http://elibrary.denr.pa.gov/GetDocument?docId= 1751030\&DocName=A175b_BedrxGeo-CoalRes ConynghamQuad.

Sevon, W.D., 2000, Physiographic provinces of Pennsylvania: Pennsylvania Geological Survey, 4th ser., Map 13, 2 p., accessed October 5, 2020, at http://elibrary.denr.pa.gov/GetDocument?docId= 1751225\&DocName=Map13_PhysProvs_Pa. 
Sevon, W.D., Rose, A.W., Smith, R.C., and Hoff, D.T., 1978, Uranium in Carbon, Lycoming, Sullivan, and Columbia Counties, Pennsylvania: Harrisburg, Pa., Field Conference of Pennsylvania Geologist, Inc., Guidebook for 43rd annual field conference of Pennsylvania Geologists October 6-7, 1978, 99 p., accessed February 2021 at https://www.fcopg.org/download-guidebooks.

Sloto, R.A., and Crouse, M.Y., 1986, HYSEP—A computer program for streamflow hydrograph separation and analysis: U.S. Geological Survey Water-Resources Investigations Report 86-4040, 46 p., accessed March 28, 2019, at https://pubs.er.usgs.gov/publication/wri964047.

Swanson, V.E., 1961, Geology and geochemistry of uranium in marine black shales-A review: U.S. Geological Survey Professional Paper 356-C, p. 67-112, accessed March 17, 2021, at https://doi.org/10.3133/pp356C.

Tetra Tech NUS, Inc., 2004a, Remedial investigation report for Operable Unit 3 (OU-3), volume 1 of 2, Valmont TCE Site, West Hazleton, Luzerne County, Pennsylvania: Prepared by Tetra Tech NUS, Inc. for EPA, July 2004, variously paginated, accessed February 2021 https://semspub.epa.gov/ work/03/2159166.pdf.

Tetra Tech NUS, Inc., 2004b, Remedial investigation report for Operable Unit 3 (OU-3), volume 2 of 2, appendices, Valmont TCE Site, West Hazleton, Luzerne County, Pennsylvania: Prepared by Tetra Tech NUS, Inc. for EPA, July 2004, variously paginated, accessed February 2021 at https://semspub.epa.gov/work/03/2065676.pdf.

Tetra Tech NUS, Inc., 2010, Treatability pilot study report for Valmont TCE Site, Hazle Township, West Hazleton Borough, Luzerne County, Pennsylvania: Prepared by Tetra Tech NUS, Inc. for EPA, August 2010, variously paginated, accessed February 2021 at https://semspub.epa.gov/work/ 03/2118208.pdf.

Tetra Tech NUS, Inc., 2011, Letter report for pre-design investigation results and scope of remedial action (revision no.1) Valmont TCE Site remedial design (RD): Prepared by Tetra Tech NUS, Inc. for EPA, July 27, 2011, variously paginated, accessed March 2021 at https://semspub.epa.gov/work/03/ 2309562.pdf.

Tetra Tech NUS, Inc., 2014, Letter report for additional data collection activities, Valmont TCE Site, long term remedial action: Prepared by Tetra Tech NUS, Inc. for EPA, September 2, 2014, variously paginated, accessed March 2021 at https://semspub.epa.gov/work/03/ 2309560.pdf.
Tetra Tech NUS, Inc., 2016, Draft summary report for data collection activities in support of optimization review, Valmont TCE Site, West Hazleton, Luzerne County, Pennsylvania: Prepared by Tetra Tech NUS, Inc. for EPA, September 7, 2016, variously paginated, accessed March 2021 at https://semspub.epa.gov/work/03/ 2309564.pdf.

Tetra Tech NUS, Inc., 2017, Redacted evaluation of aquifer test results (cover letter attached), Valmont TCE Site, long-term remedial action (LTRA), EPA work assignment 052-RALR-031M: Prepared by Tetra Tech NUS, Inc. for EPA, February 17, 2017, variously paginated, accessed April 29, 2021, at https://semspub.epa.gov/work/03/ 2309585.pdf.

Tetra Tech NUS, Inc., 2020, Redacted 3/2020 groundwater level measurement sheet prepared by Tetra Tech NUS, Inc. for EPA, March 2020, 2 p., accessed March 2021 at https://semspub.epa.gov/work/03/2309556.pdf.

U.S. Environmental Protection Agency, 1993, Evaluation of the likelihood of DNAPL presence at NPL sites, national results: U.S. Environmental Protection Agency Office of Solid Waste and Emergency Response Publication 9355.4-13 EPA 540-R-93-073 PB93-963343, September 1993, variously paginated, accessed May 2021 at https://semspub.epa.gov/work/HQ/175668.pdf.

U.S. Environmental Protection Agency, 2011, Record of decision Valmont TCE Superfund Site, Luzerne County, Pennsylvania: U.S. Environmental Protection Agency Record of Decision CERCLIS ID PAD982363970, January 2011, variously paginated, accessed February 2021 at https://semspub.epa.gov/work/03/2121986.pdf.

U.S. Environmental Protection Agency, 2015, Optimization review report, long-term response action, Valmont TCE Superfund Site, West Hazleton and Hazle Township, Luzerne County, Pennsylvania: U.S. Environmental Protection Agency Region 3, Final Report October 2015, variously paginated, accessed March 11, 2021, at https://semspub.epa.gov/work/03/2309471.pdf.

U.S. Environmental Protection Agency, 2016a, First five-year review for Valmont TCE Superfund Site, Luzerne County, Pennsylvania: U.S. Environmental Protection Agency, August 10, 2016, variously paginated, accessed June 7, 2019, at https://semspub.epa.gov/work/03/2230216.pdf.

U.S. Environmental Protection Agency, 2016b, Fact sheet PSOS \& PFOA drinking water health advisories: U.S. Environmental Protection Agency EPA 800-F-16-003, November 2016, 5 p., accessed August 2021 at https://www.epa.gov/sites/default/files/2016-06/documents/ drinkingwaterhealthadvisories_pfoa_pfos_updated_ 5.31.16.pdf. 
U.S. Environmental Protection Agency, 2016c, Redacted organic data validation report- Case 34819, Valmont TCE Site, PFCs, October 19, 2016, variously paginated, accessed April 29, 2021, at https://semspub.epa.gov/work/ 03/2309587.pdf.

U.S. Environmental Protection Agency, 2017, Technical fact sheet-Perfluorooctane sulfonate (PFOS) and perfluorooctanoic acid (PFOA): U.S. Environmental Protection Agency web page, 8 p., accessed July 23, 2021, at https:/www.epa.gov/sites/default/files/2017-12/documents/ ffrrofactsheet_contaminants_pfos_pfoa_11-20-17_ 508_0.pdf.

U.S. Environmental Protection Agency, 2018a, 2018 edition of drinking water standards and health advisory tables: U.S. Environmental Protection Agency EPA 822-F-18-001, 12 p., accessed August 2021, at https://www.epa.gov/sites/default/ files/2018-03/documents/dwtable2018.pdf.

U.S. Environmental Protection Agency, 2018b, Redacted final analytical report-DAS \# R35320, Valmont TCE Site, PFCs: U.S. Environmental Protection Agency web page, 22 p., accessed April 29, 2021, at https://semspub.epa.gov/ work/03/2309589.pdf.

U.S. Environmental Protection Agency, 2020a, Data validation report for the Valmont TCE Site (Former-Valmont Industrial Park) site for RAS\# 48760; SDG\# C0AN4: Completed by the Region III Environmental Services Assistance Team (ESAT) contractor, ICF International, under the direction of Region III LSASD, May 29, 2020, variously paginated, accessed March 11, 2021, at https://semspub.epa.gov/work/03/2309554.pdf.

U.S. Environmental Protection Agency, 2020b, Final analytical report for Valmont TCE Site, sample collection date 2/18/20-3/3/2020, project number DAS R35753, work order 2002009, report date 05/28/2020: U.S. Environmental Protection Agency web page, accessed March 11, 2021, at https://semspub.epa.gov/work/03/2309553.pdf.

U.S. Geological Survey, 2021a, Groundwater watch Pennsylvania Active Well Network: U.S. Geological Survey web page, accessed February 19, 2021, at https://groundwaterwatch.usgs.gov/StateMap.asp?sa= $\mathrm{PA} \& \mathrm{sc}=42$.

U.S. Geological Survey, 2021b, USGS GeoLog locator database: U.S. Geological Survey web page, accessed March 2021 at https://doi.org/10.5066/F7X63KT0.

U.S. Geological Survey, 2020, The National map: U.S. Geological Survey web page, accessed September 2020 at https://apps.nationalmap.gov/services/.
Welsh, S.W., 1953, Radioactivity of coal and associated rocks in the anthracite field of eastern Pennsylvania: U.S. Geological Survey Trace Element Investigations Report 348, 31 p., accessed February 2021 at https://pubs.usgs.gov/ tei/348/report.pdf.

Wood, G.H., Jr., Kehn, T.M., Carter, M.D., and Culbertson, W.C., 1983, Coal resource classification of the U.S. Geological Survey: U.S. Geological Survey Circular 891, 65 p., accessed July 2021 at https://pubs.usgs.gov/ circ/c891/.

Wood, G.H., Jr., Trexler, J.P., and Kehn, T.M., 1969, Geology of the west-central part of the Southern Anthracite Field and adjoining areas, Pennsylvania: U.S. Geological Survey Professional Paper 602, 150 p., 4 plates, accessed August 2021 at https://doi.org/10.3133/pp602. 


\section{Appendix 1. Supplementary Geophysical Log Figures}

Figures depicting geophysical logs and interpreted water-bearing zones from previous reports (Tetra Tech NUS, Inc., 2010) and annotated with comments about lithology from review of optical televiewer logs are shown for open boreholes E-1, E-2, E-3, E-4, E-5, E-6, MW-28, and MW-29 in figures 1.1 through 1.7 and figure 1.21, which, except for MW-29 (fig. 1.21) also show intervals selected for screening when boreholes were reconstructed (Tetra Tech NUS, Inc., 2016). The 250-ft-deep open borehole MW-29 is described as open from below the casing at $19 \mathrm{ft}$ bls to total depth and is not included in the list of boreholes that were reconstructed in 2016 (Tetra Tech NUS, Inc., 2016). Review of logs indicates that the depth of water-bearing fractures may differ from those shown in the initial interpretation of logs in previous reports and reproduced in figures 1.1-1.7.

Figures depicting geophysical logs and interpreted waterbearing zones from previous reports (Tetra Tech NUS, Inc., 2014) are shown for wells E-10, E-11, E-12 (MW-30), E-13, E-14, and MW-31 in figures 1.8-1.13, which also show intervals selected for screening when boreholes were reconstructed (Tetra Tech NUS, Inc., 2016). Review of logs indicates that the depth of water-bearing fractures may differ from those shown in initial interpretation of logs in previous reports and reproduced in figures 1.8-1.13.

Figures depicting geophysical logs and interpreted waterbearing zones from previous reports (Tetra Tech NUS, Inc., 2004b) and intervals selected for screening when boreholes were reconstructed (Tetra Tech NUS, Inc., 2016) are shown for wells MW-11D, MW-13D, MW-14D, MW-15D, MW-16D, MW-19, and MW-22 in figures 1.14-1.20. Figures for some wells include notes about lithology from drillers logs. 


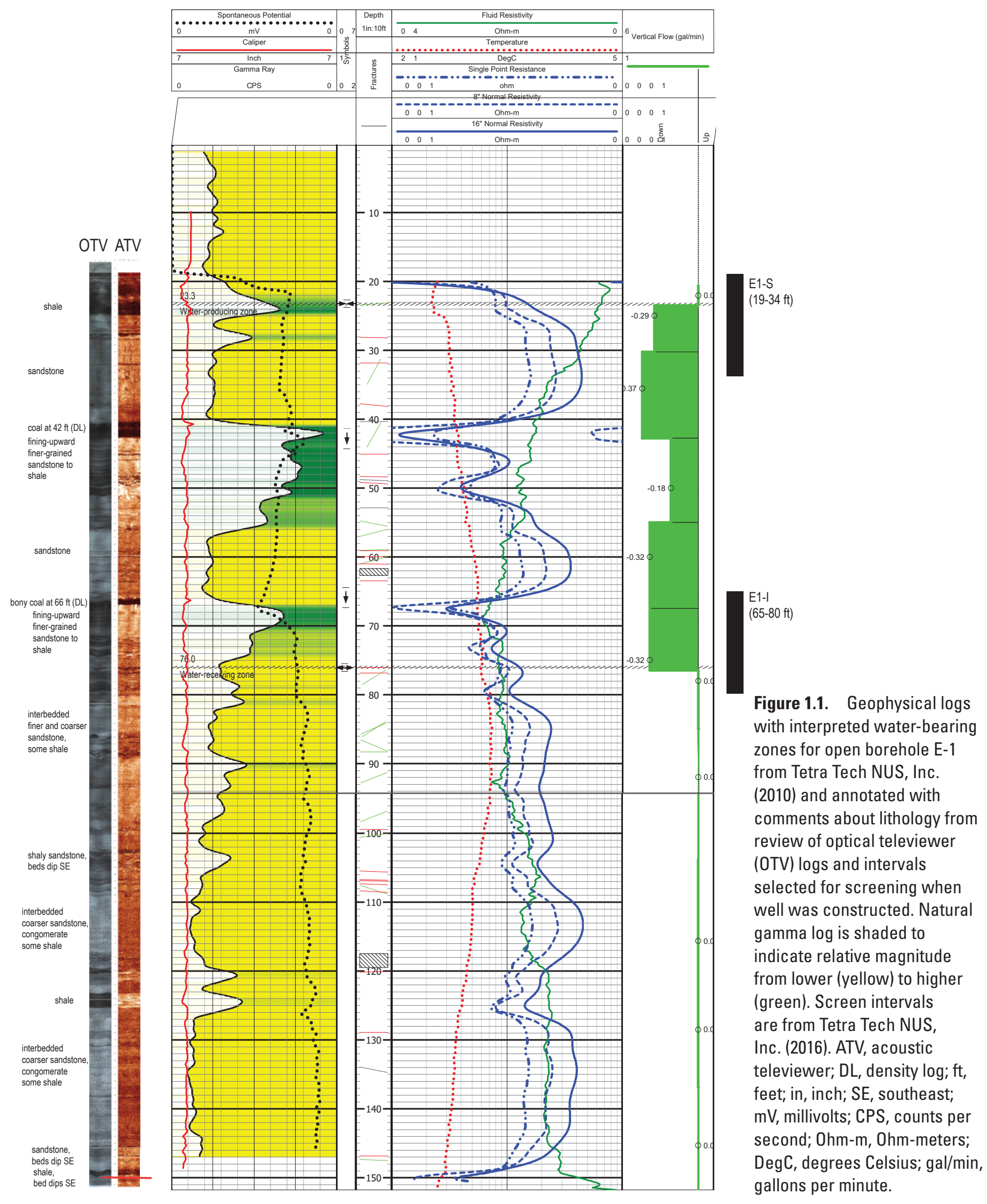




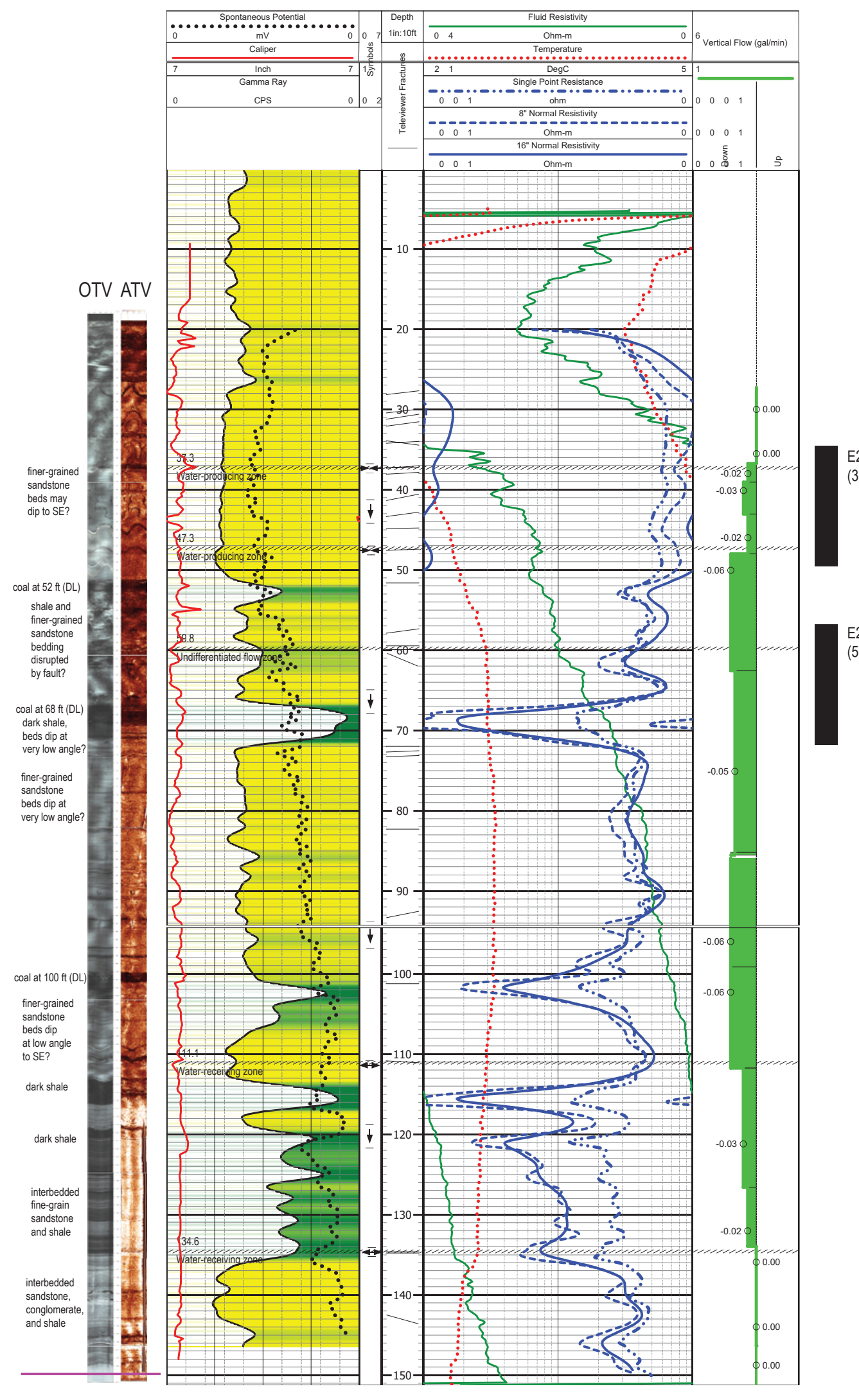

Figure 1.2. Geophysical logs with interpreted water-bearing zones for open borehole E-2 from Tetra Tech NUS, Inc. (2010) and annotated with comments about lithology from review of optical televiewer (OTV) logs and intervals selected for screening when well was constructed. Natural gamma log is shaded to indicate relative magnitude from lower (yellow) to higher (green). Screen intervals are from Tetra Tech NUS, Inc. (2016). ATV, acoustic televiewer; DL, density log; $\mathrm{ft}$, feet; in, inch; SE, southeast; $\mathrm{mV}$, millivolts; CPS, counts per second; Ohm-m, Ohm-meters; DegC, degrees Celsius; gal/min, gallons per minute. 


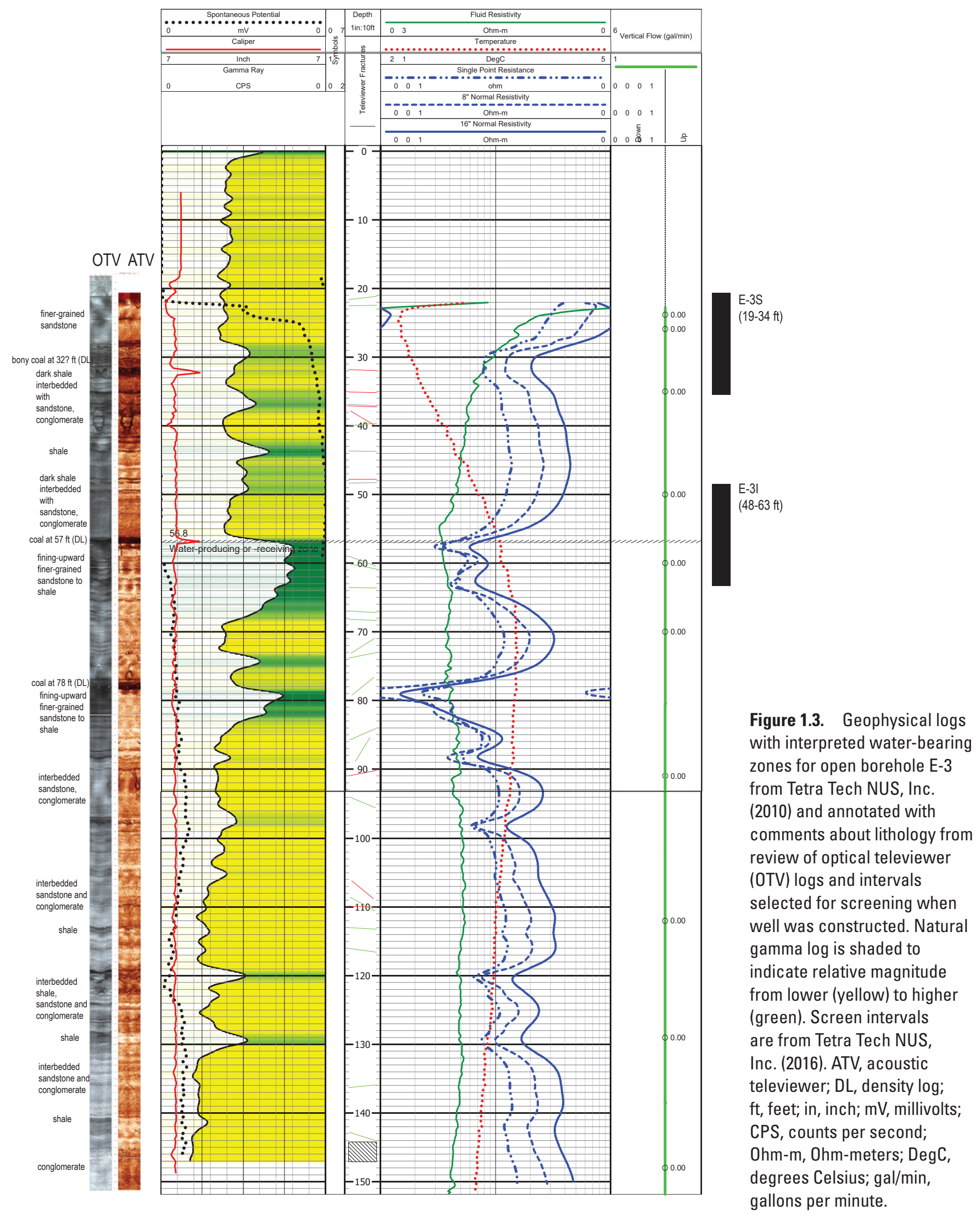




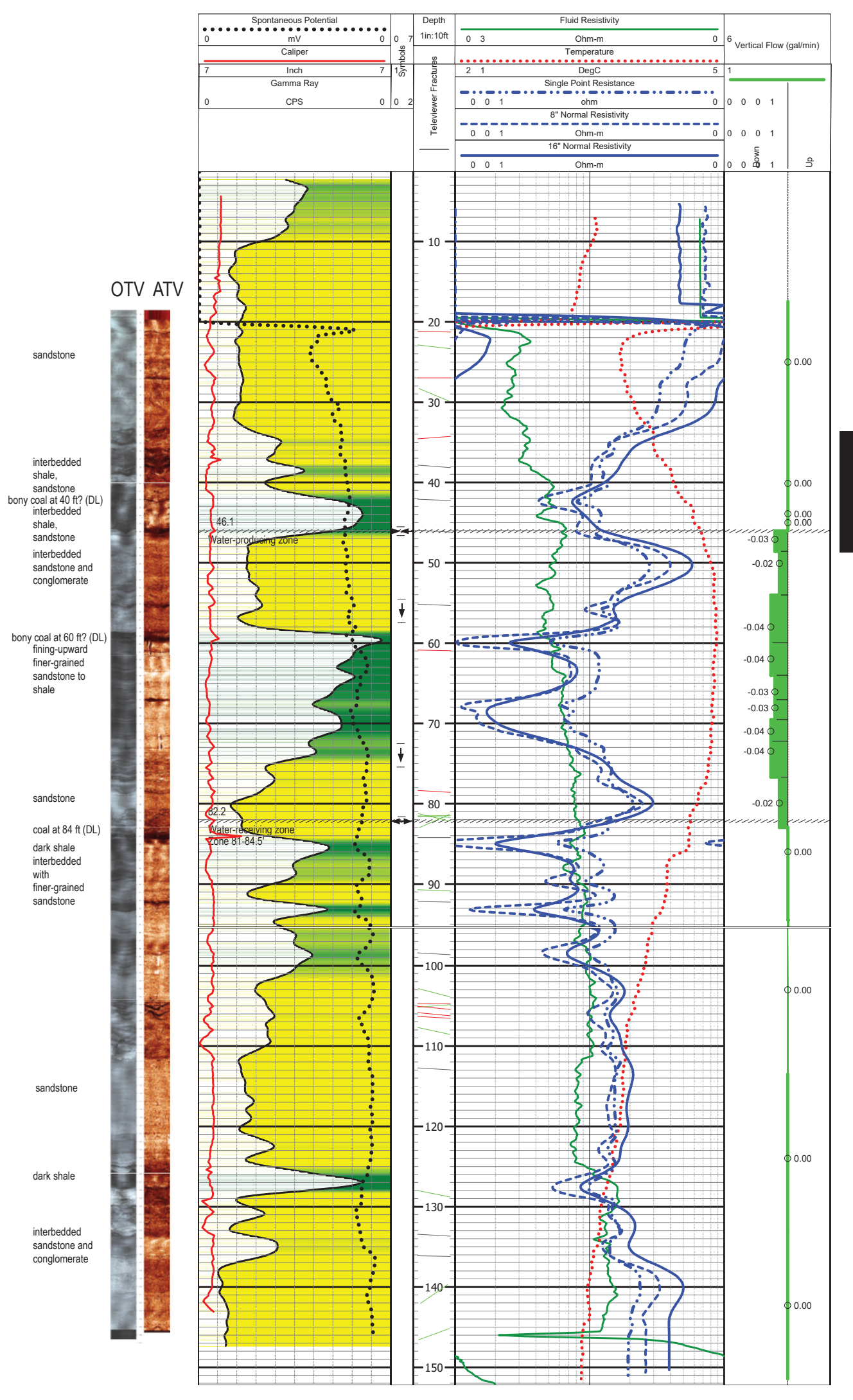

$\mathrm{E}-4 \mathrm{~S}$

(34-49 ft)

Figure 1.4. Geophysical logs with interpreted water-bearing zones for open borehole E-4 from Tetra Tech NUS, Inc. (2010) and annotated with comments about lithology from review of optical televiewer (OTV) logs and intervals selected for screening when well was constructed. Natural gamma log is shaded to indicate relative magnitude from lower (yellow) to higher (green). Screen intervals are from Tetra Tech NUS, Inc. (2016). ATV, acoustic televiewer; $\mathrm{DL}$, density log; $\mathrm{ft}$, feet; in, inch; mV, millivolts; CPS, counts per second; Ohm-m, Ohm-meters; DegC, degrees Celsius; gal/min, gallons per minute. 


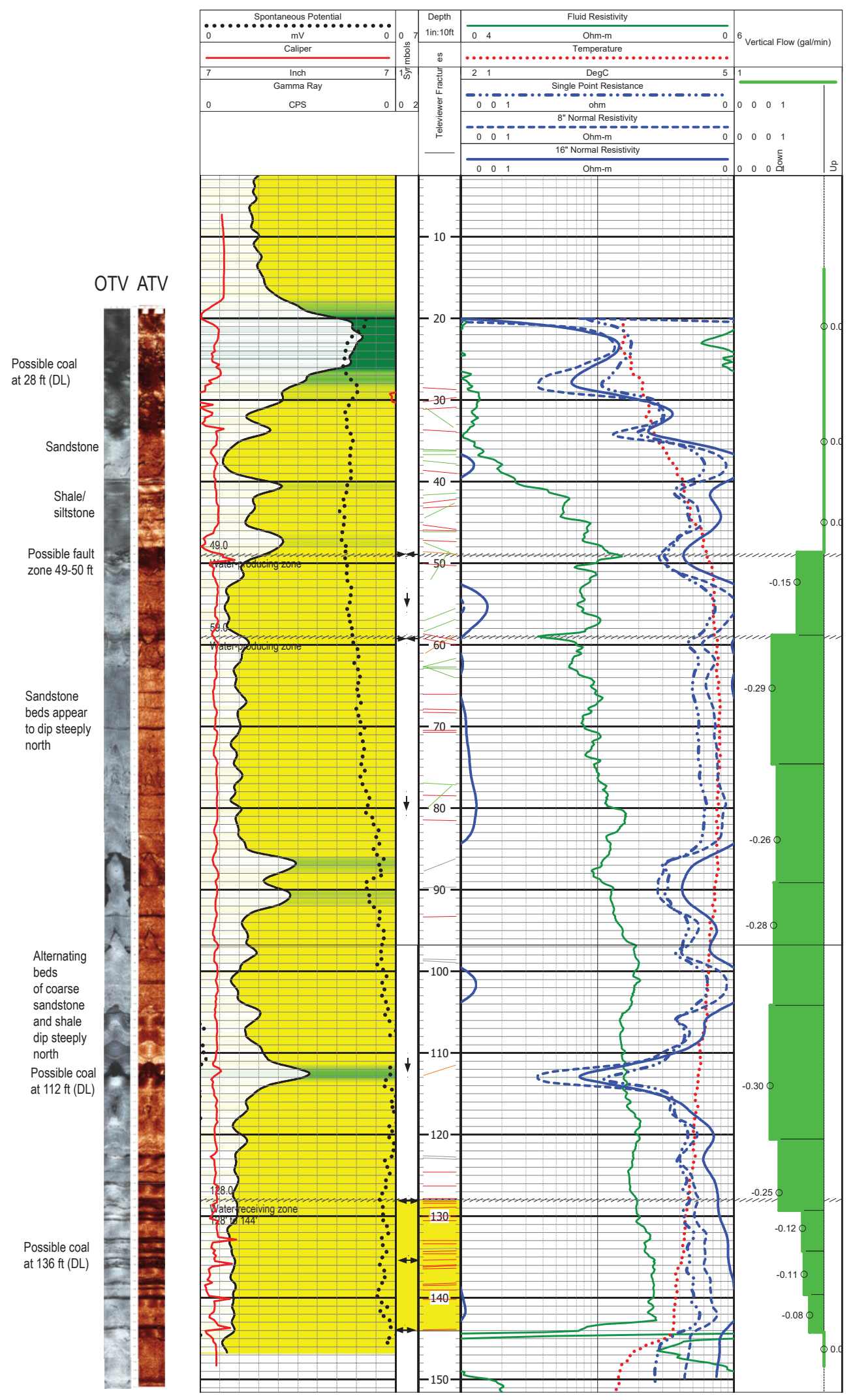

Figure 1.5. Geophysical logs with interpreted water-bearing zones for open borehole E-5 from Tetra Tech NUS, Inc. (2010) and annotated with comments about lithology from review of optical televiewer (OTV) logs and intervals selected for screening when well was constructed. Natural gamma log is shaded to indicate relative magnitude from lower (yellow) to higher (green). Screen intervals are from Tetra Tech NUS, Inc. (2016). ATV, acoustic televiewer; $\mathrm{DL}$, density log; $\mathrm{ft}$, feet; in, inch; mV, millivolts; CPS, counts per second; Ohm-m, Ohm-meters; DegC, degrees Celsius; gal/min, gallons per minute. 


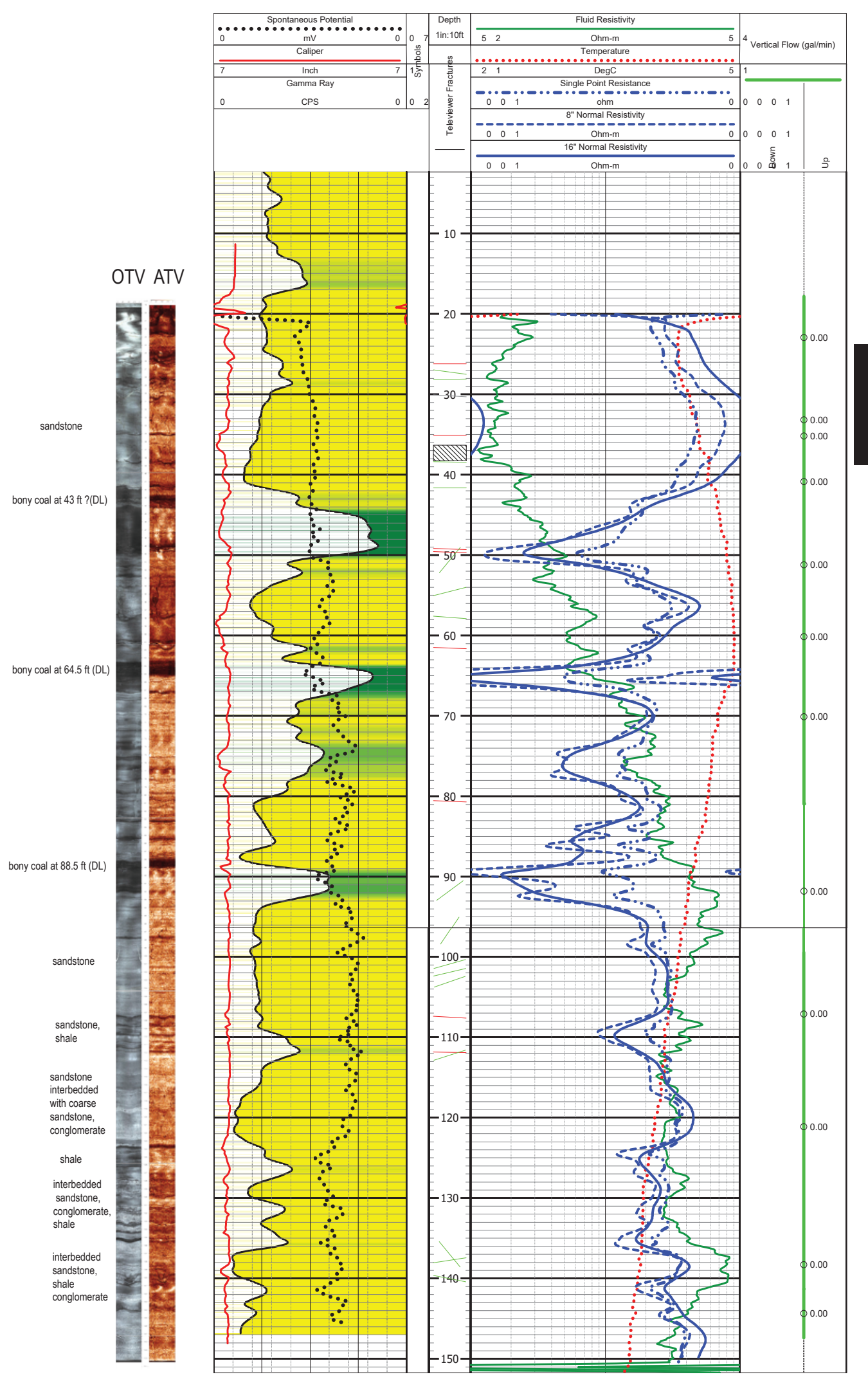

E-6S

$(24-39 \mathrm{ft})$
Figure 1.6. Geophysical logs with interpreted water-bearing zones for open borehole E-6 from Tetra Tech NUS, Inc. (2010) and annotated with comments about lithology from review of optical televiewer (OTV) logs and intervals selected for screening when well was constructed. Natural gamma log is shaded to indicate relative magnitude from lower (yellow) to higher (green). Screen intervals are from Tetra Tech NUS, Inc. (2016). ATV, acoustic televiewer; $\mathrm{DL}$, density log; $\mathrm{ft}$, feet; in, inch; mV, millivolts; CPS, counts per second; Ohm-m, Ohm-meters; DegC, degrees Celsius; gal/min, gallons per minute. 


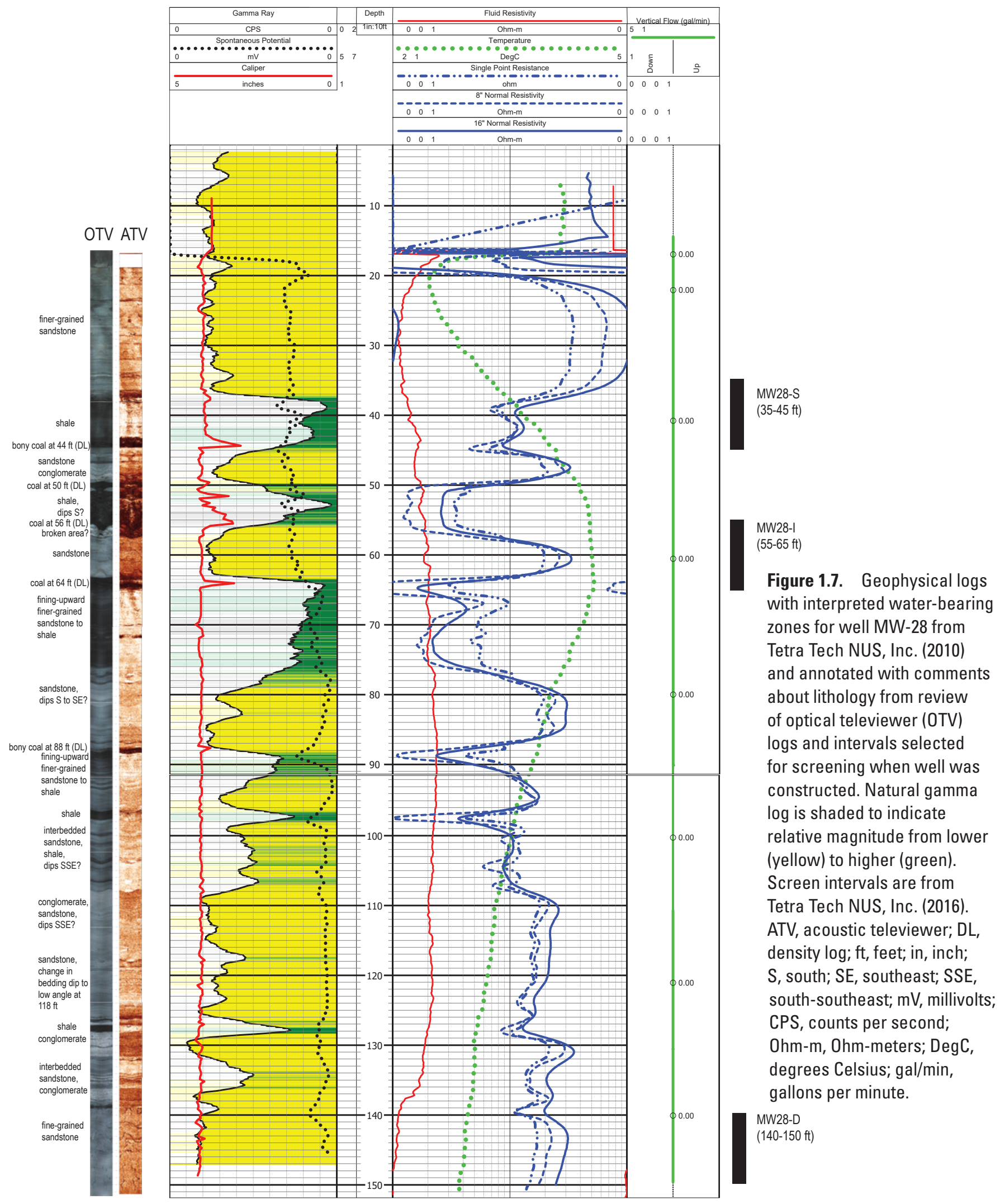




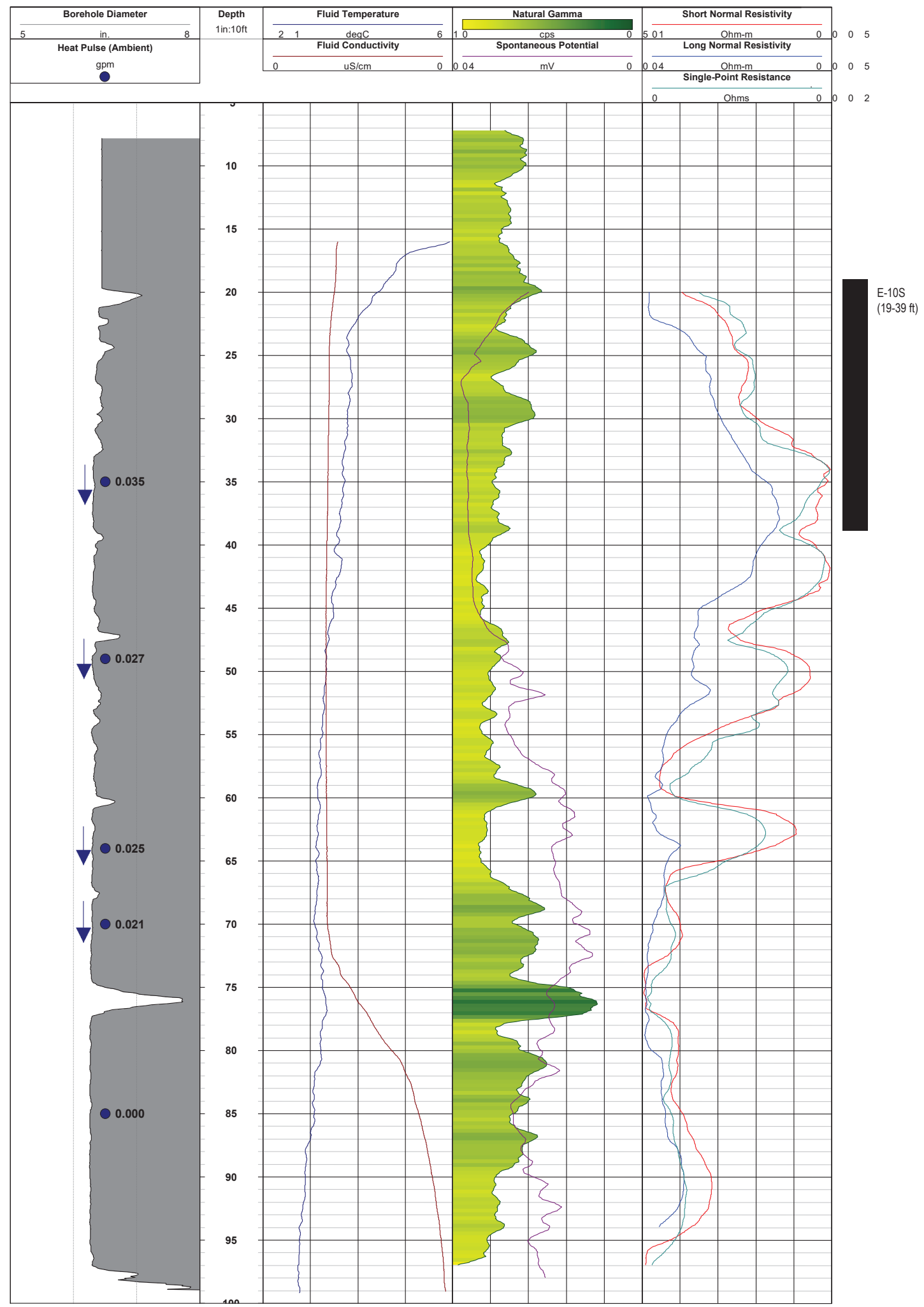

Figure 1.8. Geophysical logs for open borehole E-10 from Tetra Tech NUS, Inc. (2014) and intervals selected for screening when well was constructed. Natural gamma log is shaded to indicate relative magnitude from lower (yellow) to higher (green). Screen intervals are from Tetra Tech NUS, Inc. (2016). gpm, gallons per minute; ft, feet; in, inch; DegC, degrees Celsius; $\mu \mathrm{S} / \mathrm{cm}$, microsiemens per centimeter; cps, counts per second; mV, millivolts; Ohm-m, Ohm-meters. 


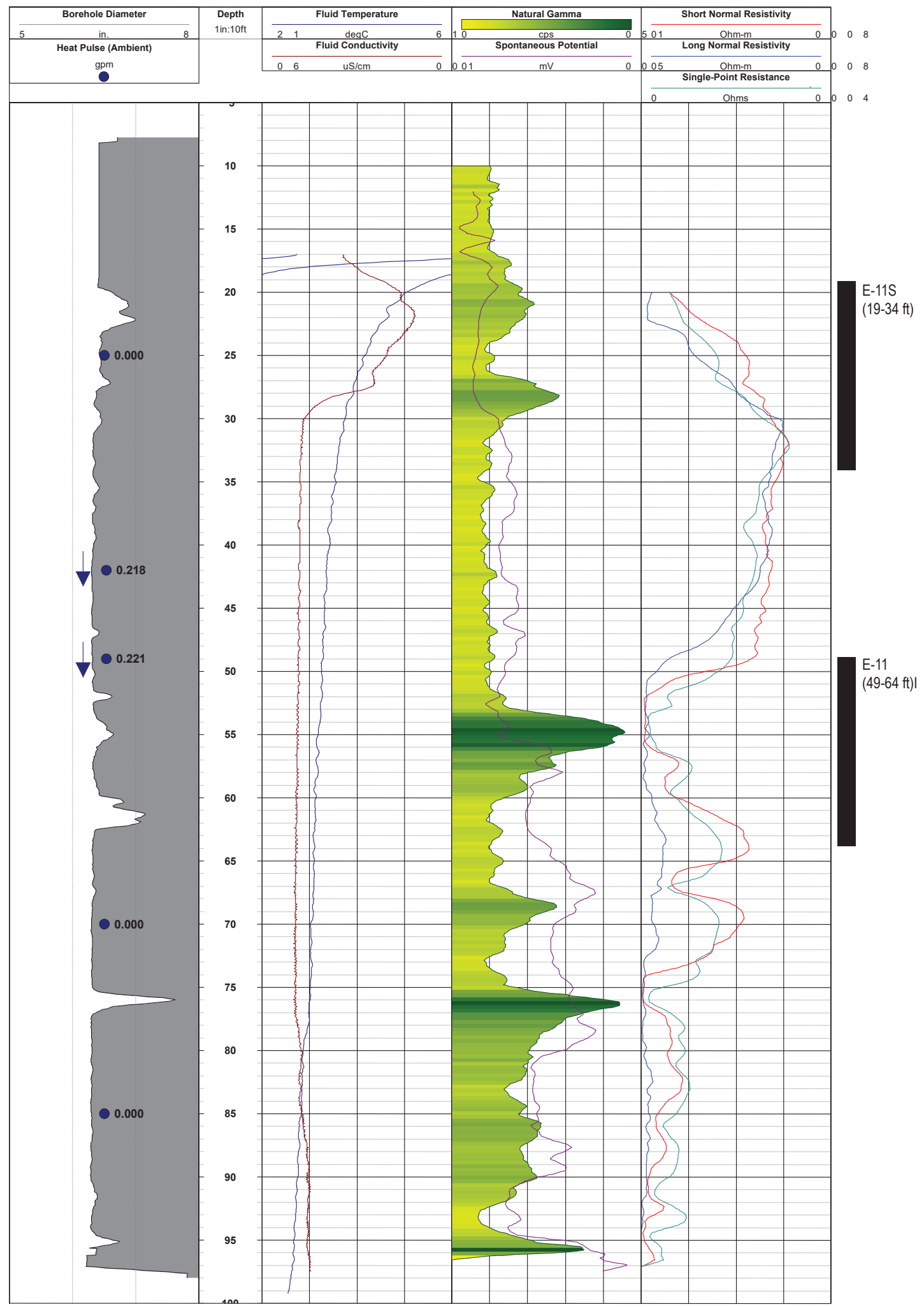

Figure 1.9. Geophysical logs for open borehole E-11 from Tetra Tech NUS, Inc. (2014) and intervals selected for screening when well was constructed. Natural gamma log is shaded to indicate relative magnitude from lower (yellow) to higher (green). Screen intervals are from Tetra Tech NUS, Inc. (2016). gpm, gallons per minute; ft, feet; in, inch; DegC, degrees Celsius; $\mu \mathrm{S} / \mathrm{cm}$, microsiemens per centimeter; cps, counts per second; $\mathrm{mV}$, millivolts; Ohm-m, Ohm-meters. 


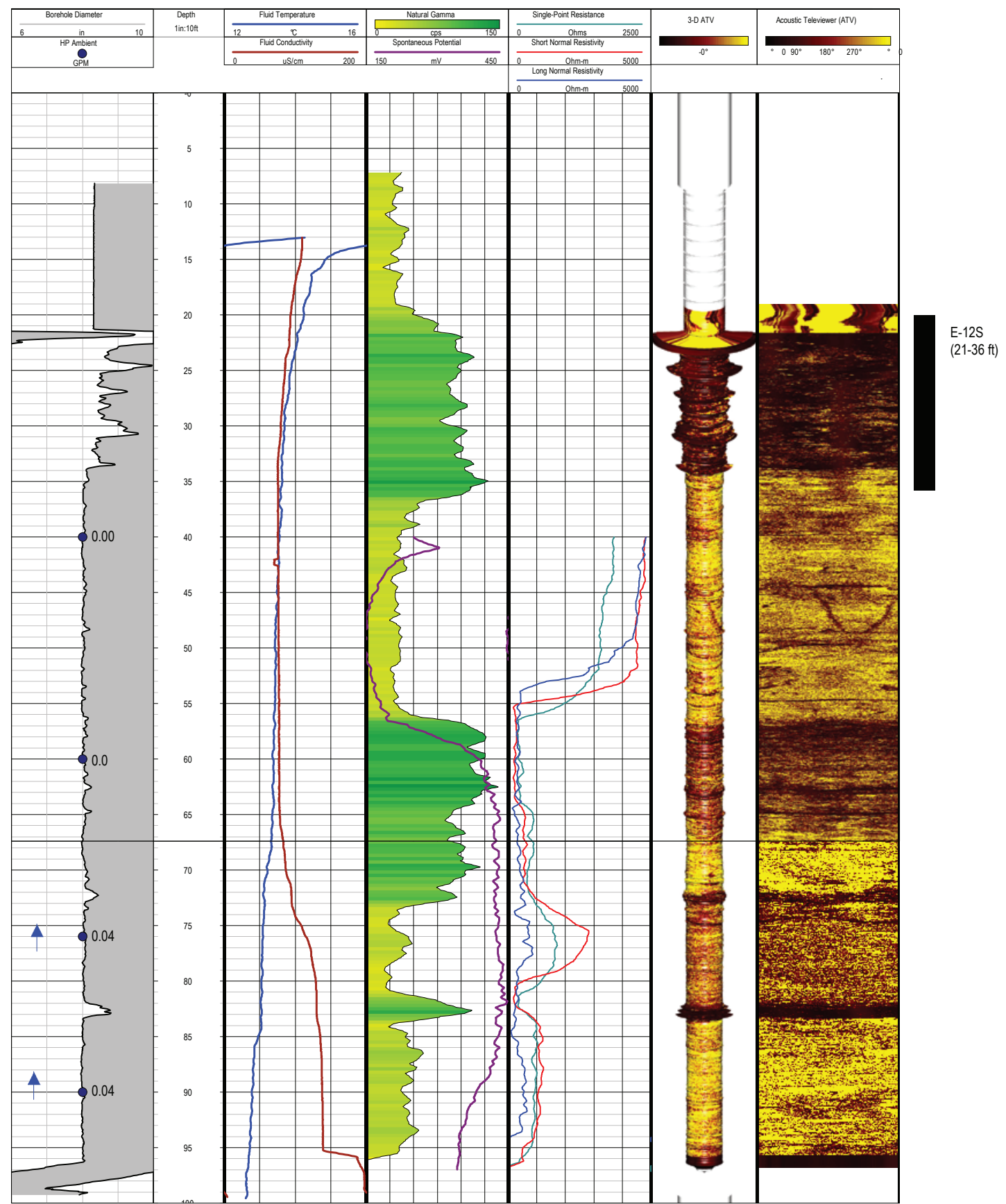

Figure 1.10. Geophysical logs for open borehole E-12 from Tetra Tech NUS, Inc. (2014) and intervals selected for screening when well was constructed. Natural gamma log is shaded to indicate relative magnitude from lower (yellow) to higher (green). Screen intervals are from Tetra Tech NUS, Inc. (2016). gpm, gallons per minute; ft, feet; in, inch; DegC, degrees Celsius; $\mu \mathrm{S} / \mathrm{cm}$, microsiemens per centimeter; $\mathrm{cps}$, counts per second; $\mathrm{mV}$, millivolts; Ohm-m, Ohm-meters; 3-D, three dimensional. 


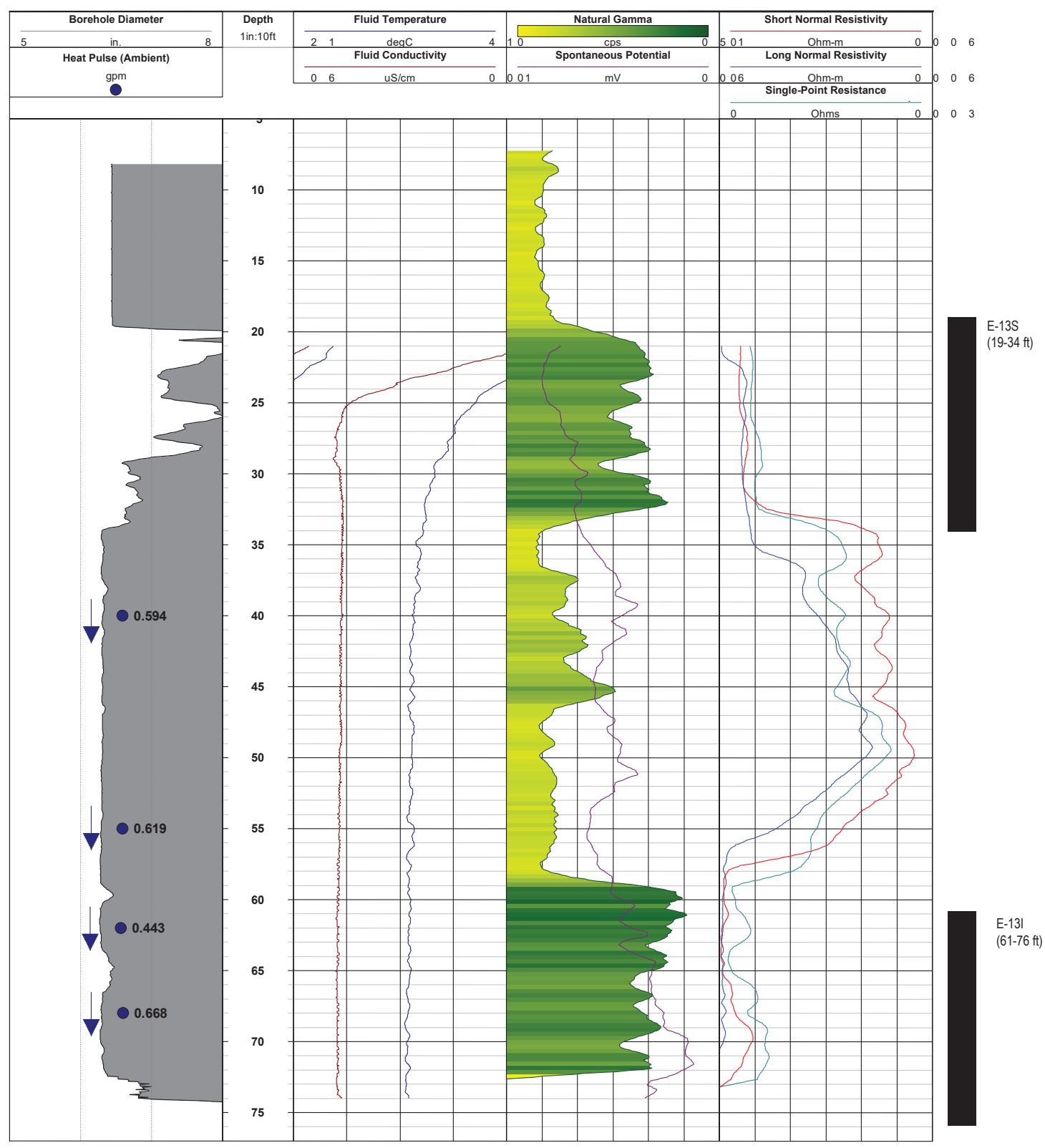

Figure 1.11. Geophysical logs for open borehole E-13 from Tetra Tech NUS, Inc. (2014) and intervals selected for screening when well was constructed. Natural gamma log is shaded to indicate relative magnitude from lower (yellow) to higher (green). Screen intervals are from Tetra Tech NUS, Inc. (2016). gpm, gallons per minute; $\mathrm{ft}$, feet; in, inch; DegC, degrees Celsius; $\mu \mathrm{S} / \mathrm{cm}$, microsiemens per centimeter; cps, counts per second; $\mathrm{mV}$, millivolts; Ohm-m, Ohm-meters. 


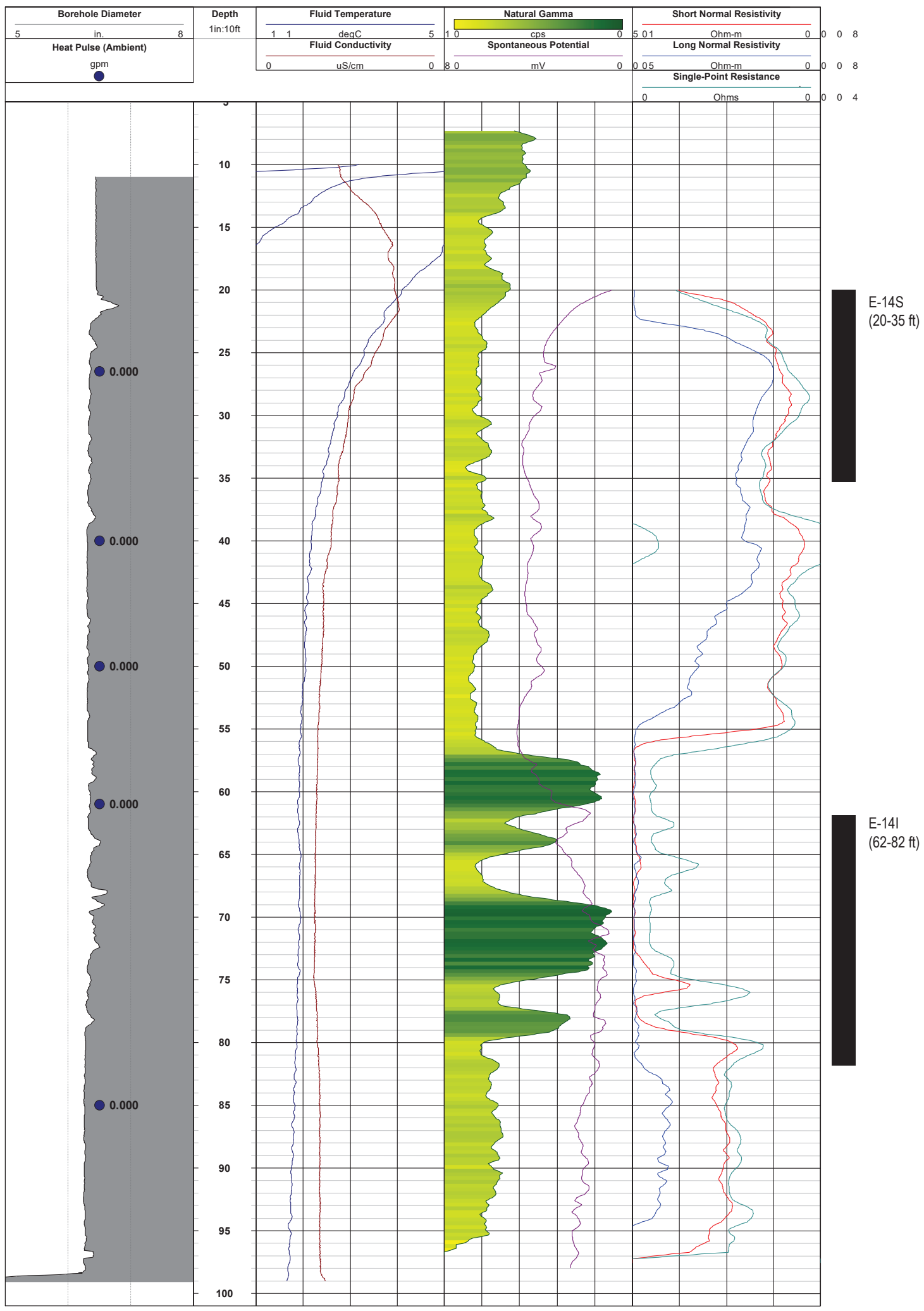

Figure 1.12. Geophysical logs for open borehole E-14 from Tetra Tech NUS, Inc. (2014) and intervals selected for screening when well was constructed. Natural gamma log is shaded to indicate relative magnitude from lower (yellow) to higher (green). Screen intervals are from Tetra Tech NUS, Inc. (2016). gpm, gallons per minute; $\mathrm{ft}$, feet; in, inch; DegC, degrees Celsius; $\mu \mathrm{S} / \mathrm{cm}$, microsiemens per centimeter; $\mathrm{cps}$, counts per second; $\mathrm{mV}$, millivolts; Ohm-m, Ohm-meters. 


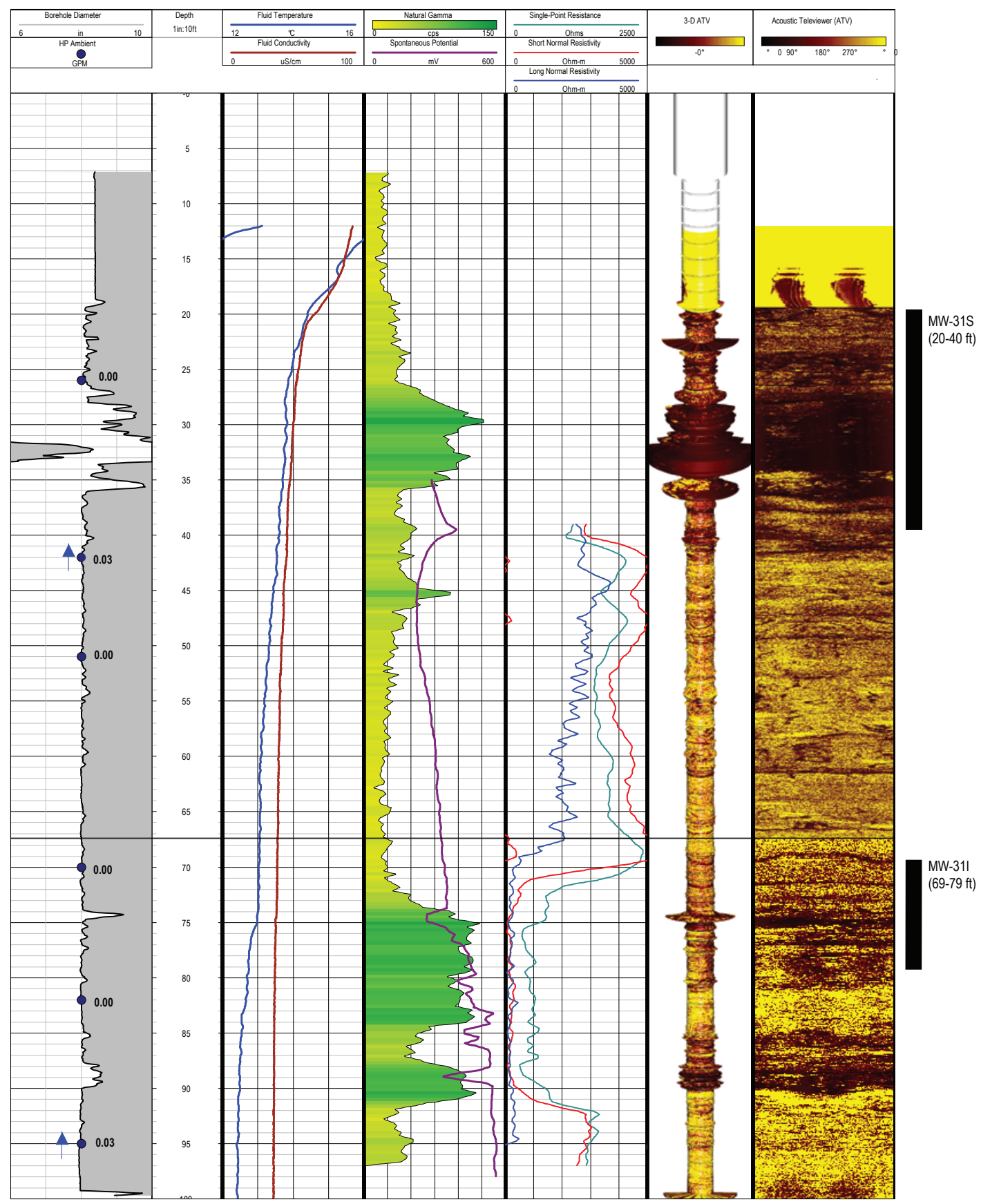

Figure 1.13. Geophysical logs for open borehole MW-31 from Tetra Tech NUS, Inc. (2014) and intervals selected for screening when well was constructed. Natural gamma log is shaded to indicate relative magnitude from lower (yellow) to higher (green). Screen intervals are from Tetra Tech NUS, Inc. (2016). gpm, gallons per minute; ft, feet; in, inch; DegC, degrees Celsius; $\mu \mathrm{S} / \mathrm{cm}$, microsiemens per centimeter; cps, counts per second; $\mathrm{mV}$, millivolts; Ohm-m, Ohm-meters; 3-D, three dimensional. 


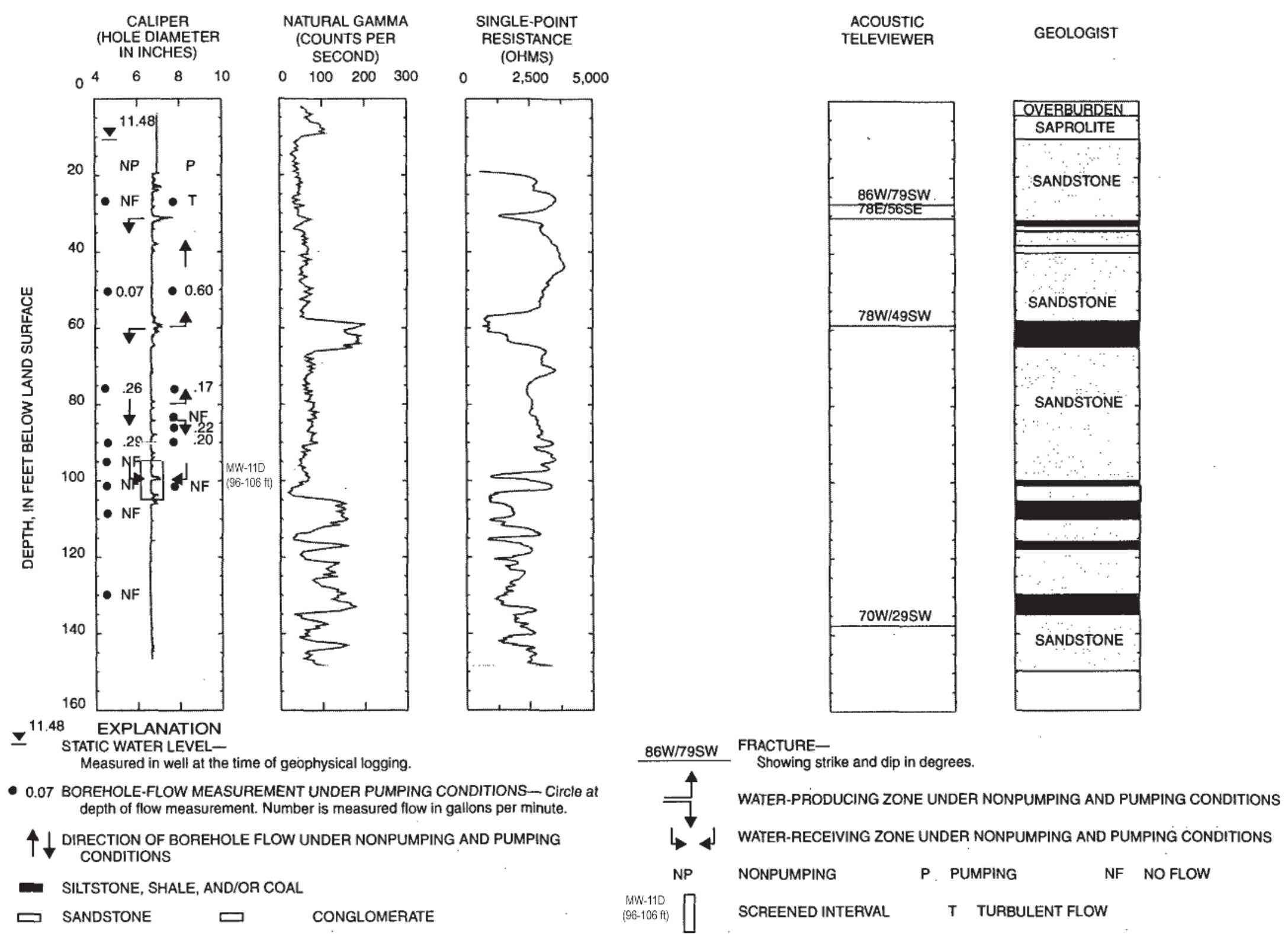

Figure 1.14. Geophysical logs with interpreted water-bearing zones for open borehole MW-11D (USGS well LU-755) and notes about lithology from drillers logs, fracture orientations from interpretation of ATV logs, and intervals selected for screening when well was constructed. Figure from Tetra Tech NUS, Inc. (2004b), in which well was mislabeled as MW-15D. W, west; SW, southwest; E, east; SE, southeast. 


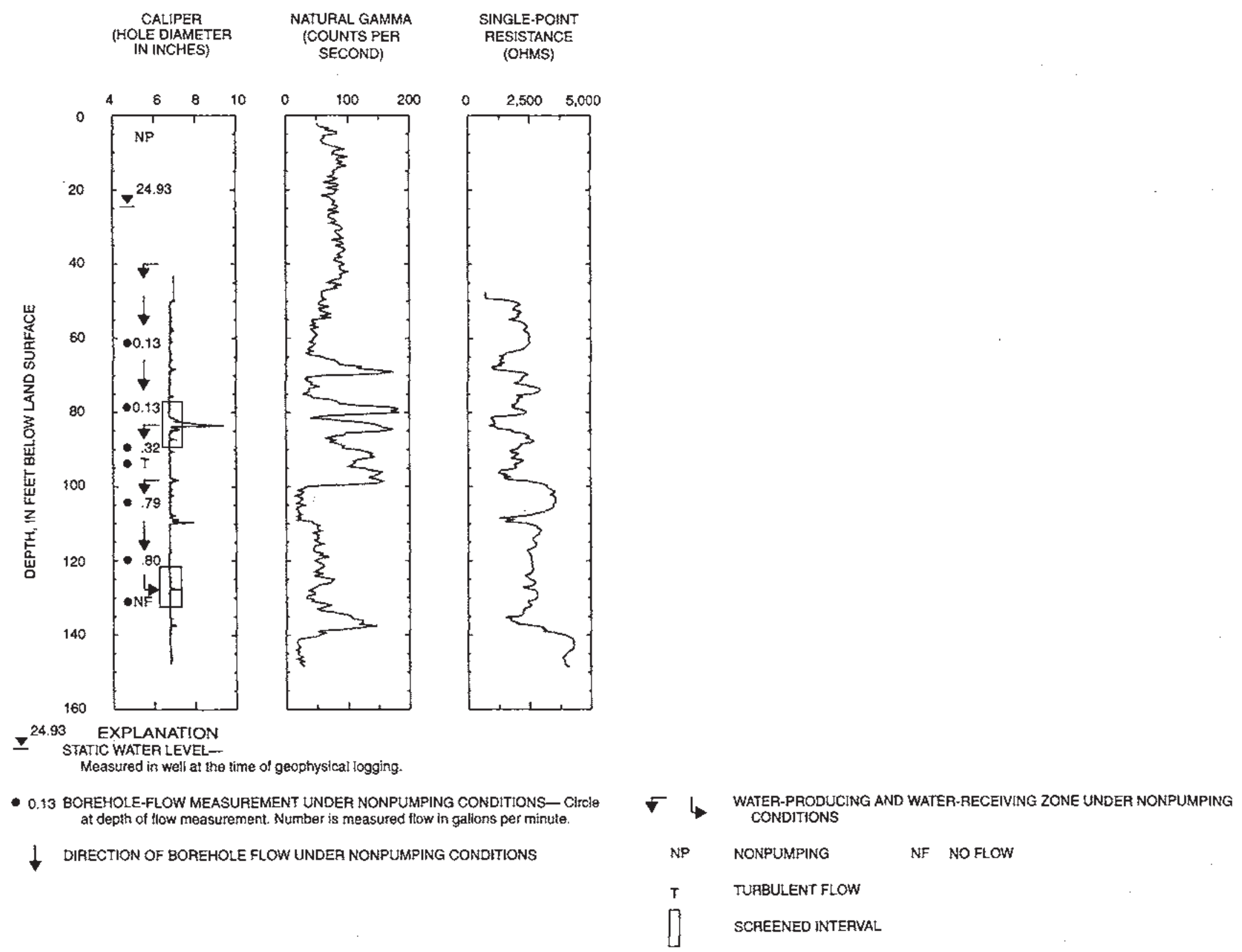

Figure 1.15. Geophysical logs with interpreted water-bearing zones for open borehole MW-13D (USGS well LU-762) and intervals selected for screening when well was constructed. Figure from Tetra Tech NUS, Inc. (2004b). 


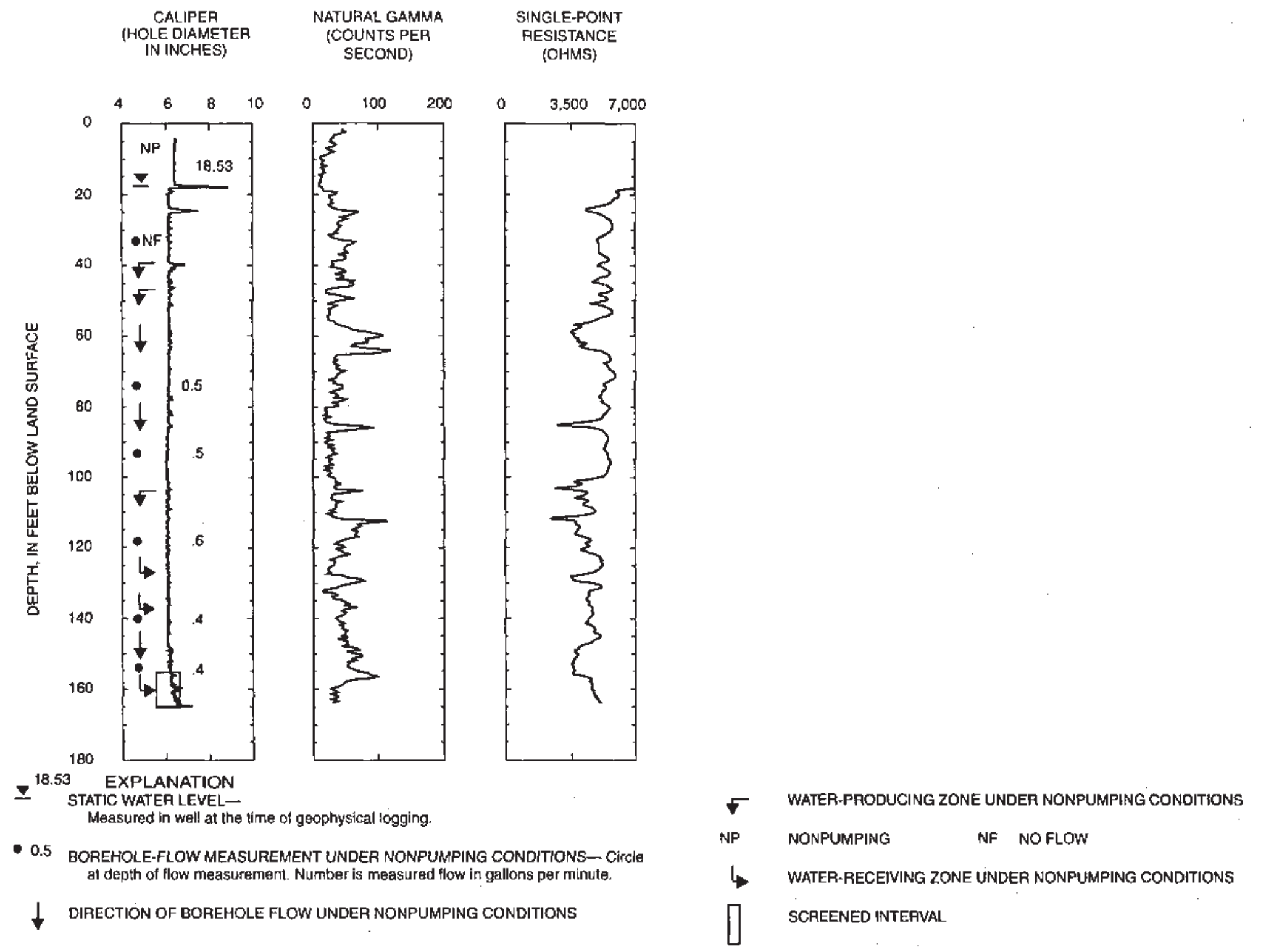

Figure 1.16. Geophysical logs with interpreted water-bearing zones for open borehole MW-14D (USGS well LU-766) and intervals selected for screening when well was constructed. Figure from Tetra Tech NUS, Inc. (2004b). 


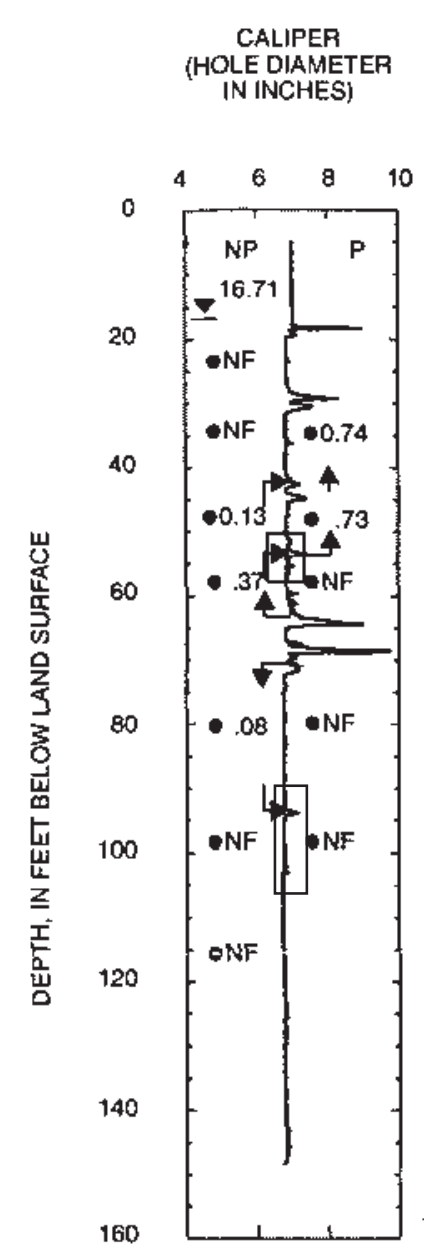

$\nabla^{16.71}$ EXPLANATION

STATIC WATER LEVEL-
Measured in well al the time of geophysical logging.

- 0.13 BOREHOLE-FLOW MEASUREMENT UNDER NONPUMPING AND PUMPING CONDITHONS-Circle at depth of flow measurement. Number is maasured flow in gallons per minute.

$\uparrow$ DIRECTION OF BOREHOLE FLOW UNDER PUMPING CONDITIONS
Notes from drillers logs

\section{sandstone/}

conglomerate

coal /shale at $32 \mathrm{ft}$

conglomerate

coal / shale at $42 \mathrm{ft}$

shale

sandstone

coal /shale at $70 \mathrm{ft}$

shale

sandstone

coal/shale at $95 \mathrm{ft}$

coal/shale at $104 \mathrm{ft}$

\section{sandstone/}

conglomerate

\section{WATER-PRODUCING ZONE UNDER NONPUMPING ANO PUMPING CONOITIONS}

NP NONPUMPING $P$ PUMPING NF NOFLOW
WATER-AECEIVING ZONE UNDER NONPUMPING CONDITIONS SCREENED INTERVAL

Figure 1.17. Geophysical logs with interpreted water-bearing zones for open borehole MW-15D (USGS well LU-765) and notes about lithology from drillers logs and intervals selected for screening when well was constructed. Figure from Tetra Tech NUS, Inc. (2004b), in which well was labeled as MW-15. ft, feet. 


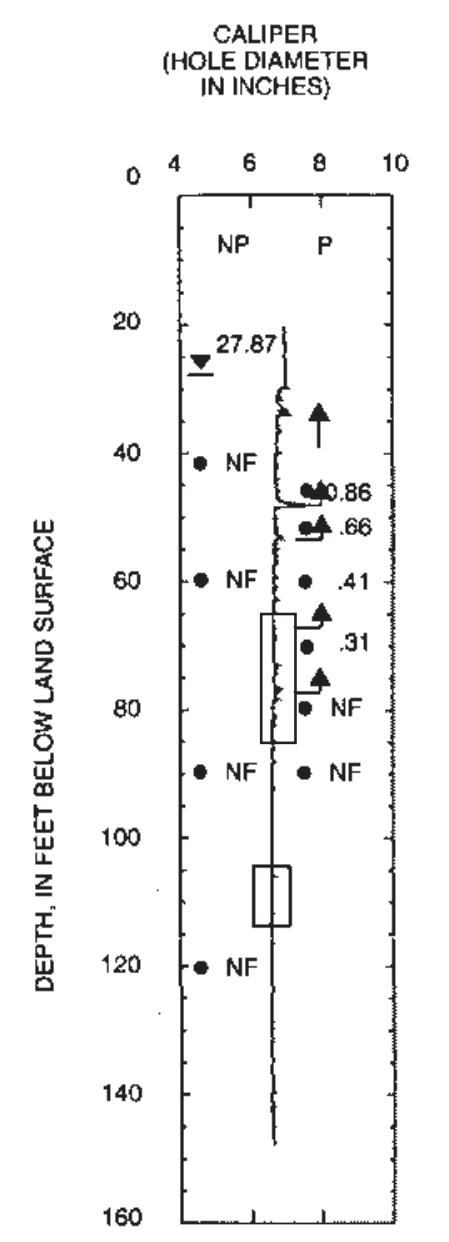

27.87 EXPLANATION

$\square^{27.87}$ STATIC WATER LEVEL-

Measured in well at the time of geophysical logging.

- 0.86 BOAEHOLE-FLOW MEASUREMENT UNDER PUMPING CONDITIONS-Circle at depth of flow measurement. Number is measured flow in gallons per minute.

$\uparrow$ DIRECTION OF BOREHOLE FLOW UNDER PUMPING CONDITIONS

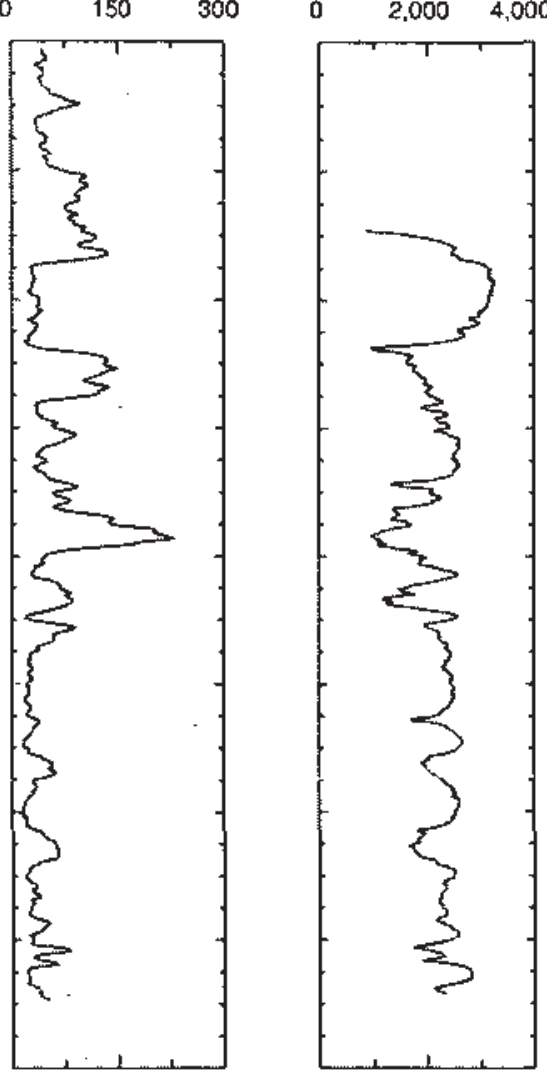

- SILTSTONE, SHALE, and/or COAL

$\sqsubset$ SANDSTONE $\sqsubset$

CONGLOMERATE
GEOLOGIST

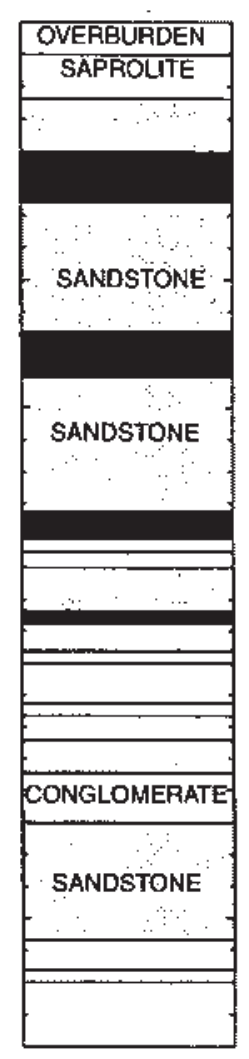

\section{* WATER-PRODUCING ZONE UNDER PUMPING CONDITIONS}

NP NONPUMPING P PUMPING

NF NOFLOW SCREENED INTERVAL

Figure 1.18. Geophysical logs with interpreted water-bearing zones for open borehole MW-16D (USGS well LU-757) and intervals selected for screening when well was constructed. Figure from Tetra Tech NUS, Inc. (2004b). 


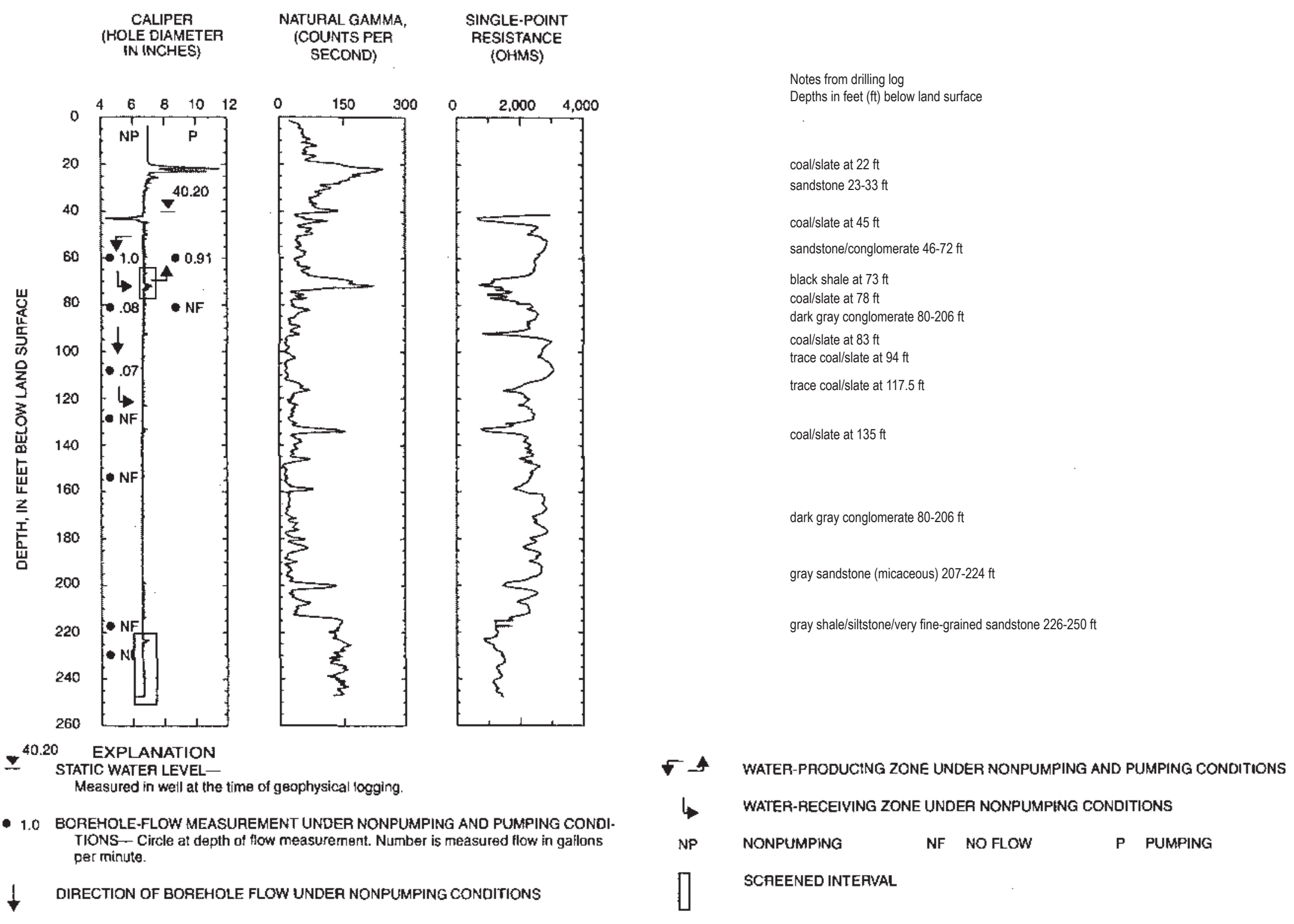

Figure 1.19. Geophysical and driller's logs for open borehole MW-19D showing the contact between the Pottsville Formation and underlying Mauch Chunk Formation and the screened interval for well MW-19D. The estimated depth of contact between the units is about 218 feet below land surface, as determined from the natural gamma log. Figure from Tetra Tech NUS, Inc. (2004b). 


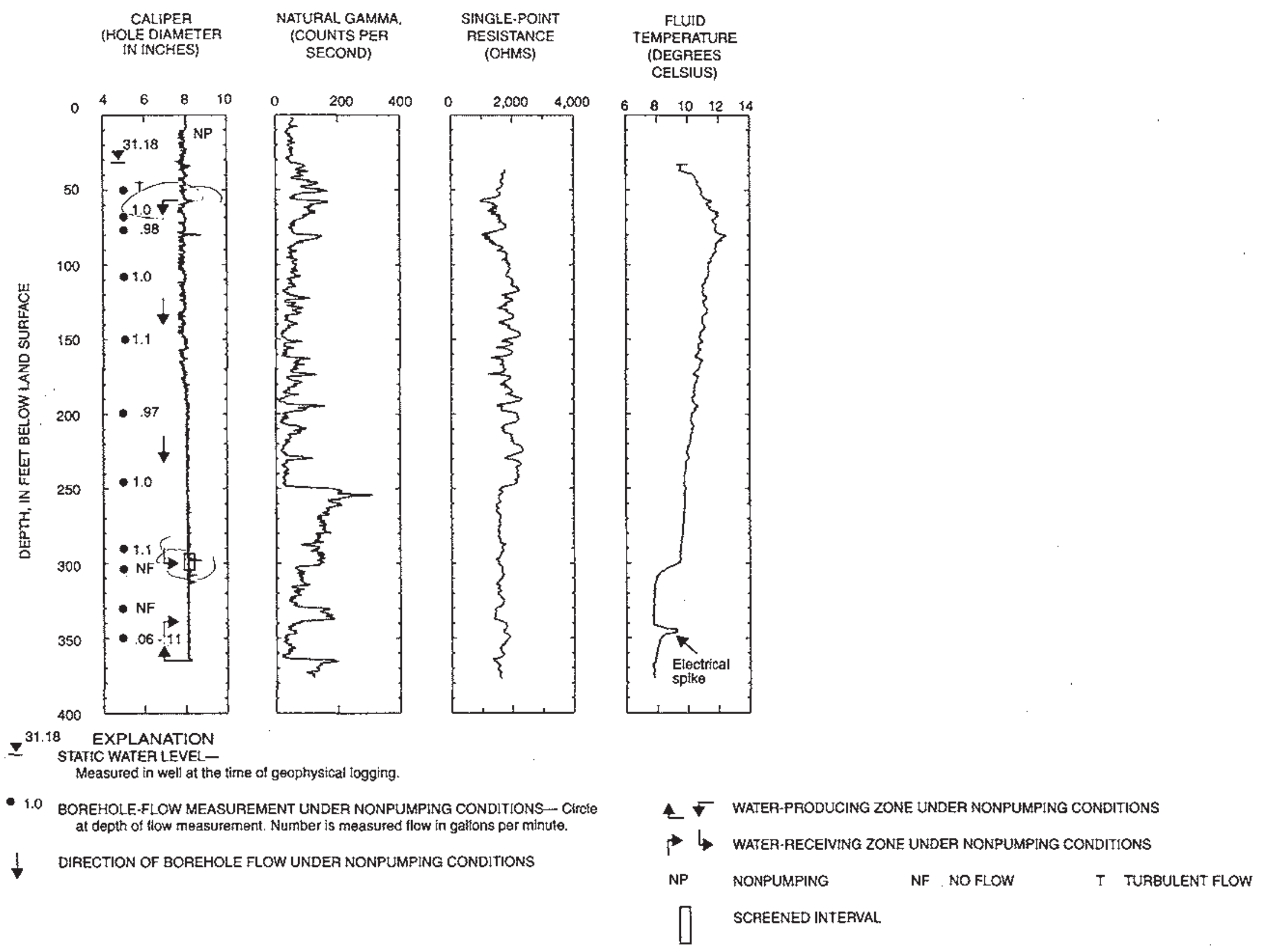

Figure 1.20. Geophysical logs with interpreted water-bearing zones for open borehole MW-22 (PW-1; USGS well LU-750) from Tetra Tech NUS, Inc. (2004b), the interval selected for screening when the well was constructed, and the contact between the Pottsville Formation and underlying Mauch Chunk Formation. The estimated depth of contact between the geologic units is about 250 feet below land surface, as determined from the natural gamma log. 

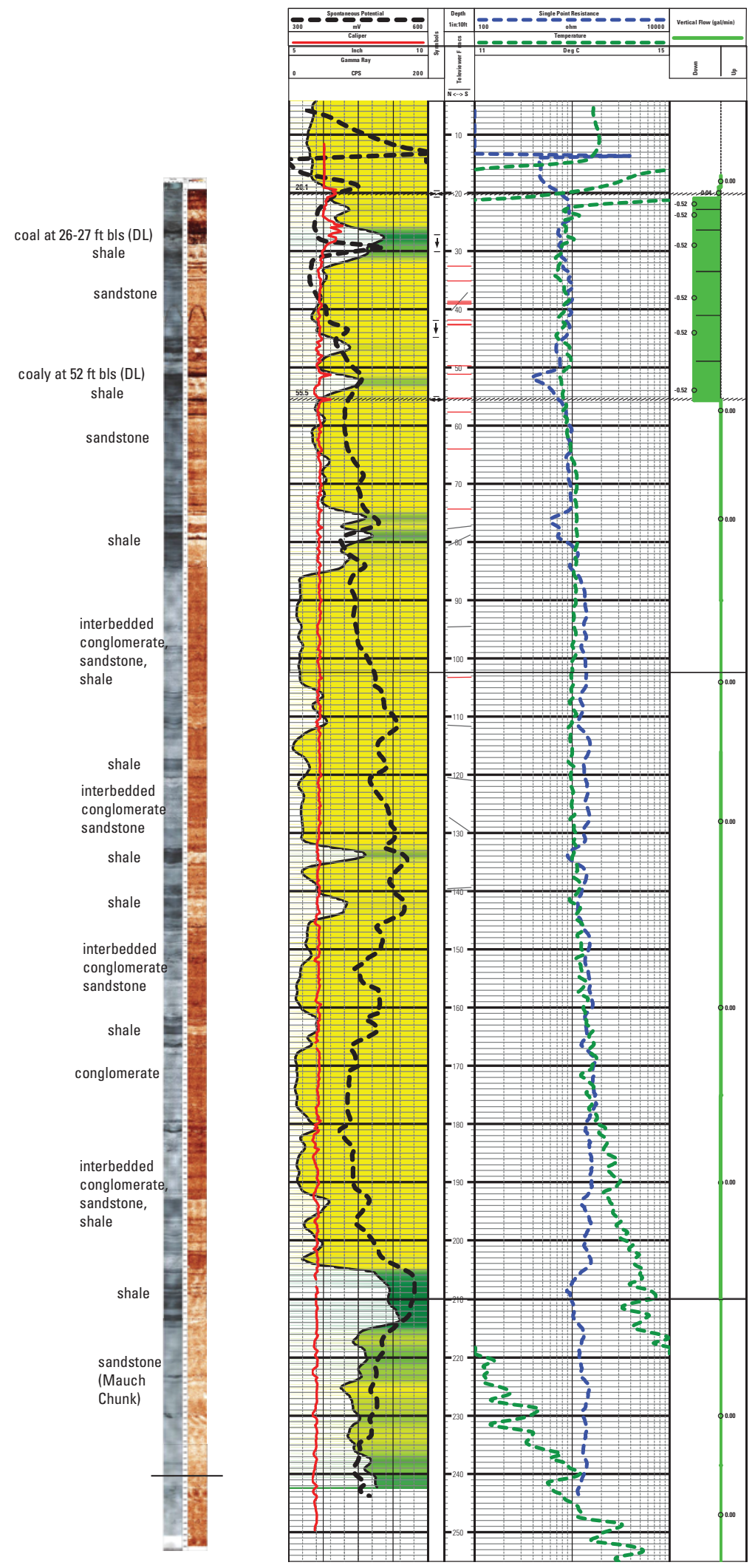

Figure 1.21. Geophysical logs with interpreted water-bearing zones for well MW-29 from Tetra Tech NUS, Inc. (2010) and annotated with comments about lithology from review of optical televiewer (OTV) logs. Natural gamma log is shaded to indicate relative magnitude from lower (yellow) to higher (green). ATV, acoustic televiewer; DL, density log; $\mathrm{ft}$, feet; bls, below land surface; in, inch; mV, millivolts; CPS, counts per second; $0 \mathrm{hm}-\mathrm{m}$, Ohm-meters; DegC, degrees Celsius; gal/min, gallons per minute. 


\section{Appendix 2. Supplementary Hydrologic Data}

\section{Specific Capacity Data from Packer Tests}

Using field notes collected during interval-isolation (packer tests) conducted during January-February 2016 in open boreholes wells E-1 through E-14 (appendix G in Tetra Tech NUS, Inc., 2016), corrected specific capacity values, where possible, are listed with previously reported values in table 2.1. For intervals in some other wells, reported specific capacities (Tetra Tech NUS, Inc., 2016) likely are higher than actual, as drawdowns were affected (reduced) by interconnection with adjacent intervals or were calculated using elevated prepumping water levels that had not equilibrated.

\section{Water-Level Data}

Water levels were measured and reported in selected wells at the Valmont TCE Superfund Site on March 4, 2020, with respect to measuring points with surveyed altitudes (Tetra Tech NUS, Inc., 2020). The measuring points for wells may be above or below land surface, depending on well construction. Using land-surface altitudes for well locations as determined by survey or as estimated from light detection and ranging (lidar) digital elevation data (Pennsylvania Spatial Data Access, 2015) if no survey data were available, March 2020 water levels were calculated in terms of values for depth to water below land surface (table 2.2). 
Table 2.1. Specific capacities for intervals isolated by packers in selected wells, listed by well and by depth of interval tested at the Valmont TCE Superfund Site, Luzerne County, Pennsylvania. Specific capacity values from, or revised as noted using field notes, from Tetra Tech NUS, Inc. (2016).

[ft bls, feet below land surface; (gal/min)/ft, gallons per minute per foot drawdown; NCR, no constant rate for pumping; ND, not determined for low-producing zone; WL, water level; LSD, land-surface datum; dd, drawdown; ?, uncertain value]

\begin{tabular}{|c|c|c|c|c|c|c|c|}
\hline Well & $\begin{array}{c}\text { Depth range } \\
\text { for isolated } \\
\text { interval, } \\
\text { in ft bls }\end{array}$ & $\begin{array}{l}\text { Test duration, } \\
\text { in minutes }\end{array}$ & $\begin{array}{c}\text { Average } \\
\text { pumping rate, } \\
\text { in gal/min }\end{array}$ & $\begin{array}{c}\text { Reported } \\
\text { specific } \\
\text { capacity, } \\
\text { in }(\text { gal } / \text { min)/ft }\end{array}$ & $\begin{array}{c}\text { Revised } \\
\text { specific } \\
\text { capacity, } \\
\text { in }(\text { gal } / \mathrm{min}) / \mathrm{ft}\end{array}$ & $\begin{array}{c}\text { Span } \\
\text { shale } \\
\text { contact }^{\mathrm{a}}\end{array}$ & Review notes for reported or revised specific capacity vales \\
\hline E-1 & 19-39 & 153 & 1.1 & 0.107 & 0.107 & $\mathrm{X}$ & \\
\hline E-1 & $64-84$ & 68 & 0.25 & 0.0062 & 0.0062 & $\mathrm{X}$ & Interval not equilibrated before pumping began-pre-pumping WL near LSD \\
\hline E-1 & 99-119 & 53 & 0.22 & 0.0024 & $0.0057^{\mathrm{b}}$ & $\mathrm{O}^{\mathrm{b}}$ & Interval not equilibrated before pumping began-pre-pumping WL above LSD \\
\hline E-2 & $30-50$ & 70 & 3 & 0.225 & 0.225 & $\mathrm{O}$ & \\
\hline E-2 & $50-70$ & 98 & 1.25 & 0.067 & 0.067 & $\mathrm{X}$ & \\
\hline E-2 & $100-120$ & 53 & 0.22 & 0.0024 & 0.0024 & $\mathrm{X}$ & Interval not equilibrated before pumping began-pre-pumping WL above LSD \\
\hline E-3 & $19-39$ & 71 & 2.4 & 1.71 & $0.1959^{\mathrm{b}}$ & $\mathrm{X}^{\mathrm{b}}$ & Reported specific capacity calculated for dd in middle zone \\
\hline E-3 & $45-65$ & 91 & 1.3 & 0.117 & 0.117 & $\mathrm{X}$ & \\
\hline E-4 & $30-50$ & 85 & 2.5 & 1.02 & $0.290^{\mathrm{b}}$ & $\mathrm{X}^{\mathrm{b}}$ & Reported specific capacity calculated for dd in middle zone (which was $1.54 \mathrm{ft}$ ) \\
\hline E-4 & $70-90$ & 15 & NCR & ND & ND & $\mathrm{X}$ & \\
\hline E-4 & $95-115$ & 16 & NCR & ND & ND & $\mathrm{O}$ & \\
\hline E-5 & $20-40$ & 64 & 3.5 & 0.622 & 0.622 & $\mathrm{X}$ & $\begin{array}{l}1.61 \mathrm{ft} d \mathrm{~d} \text { observed below pumped zone; reported specific capacity too high for } \\
20-40 \text { ? Interconnection }\end{array}$ \\
\hline E-5 & $45-65$ & 29 & 6 & 1.097 & 1.097 & $\mathrm{O}$ & $\begin{array}{l}\text { Large dd (3.84 ft) observed in upper interval, reported specific capacity too high for } \\
45-65 \text { ? Interconnection; spans faults }\end{array}$ \\
\hline E-6 & $19-39$ & 50 & 3 & 1.54 & $0.3735^{\mathrm{b}}$ & $\mathrm{O}^{\mathrm{b}}$ & Reported specific capacity calculated for dd in middle zone (which was $1.95 \mathrm{ft}$ ) \\
\hline E-6 & $45-65$ & 6 & NCR & ND & ND & $\mathrm{X}$ & \\
\hline E-6 & $95-115$ & 14 & NCR & ND & ND & $\mathrm{O}$ & \\
\hline E-7 & $19-39$ & 86 & 1.6 & 0.136 & 0.136 & $\mathrm{X}$ & \\
\hline E-7 & $47-67$ & 206 & 0.65 & 0.313 & $0.0538^{b}$ & $\mathrm{X}^{\mathrm{b}}$ & From dd and pumping rate on day 2 \\
\hline E-7 & $70-90$ & 8 & NCR & ND & ND & $\mathrm{O}$ & \\
\hline E-8 & $19-39$ & 94 & 2 & 0.587 & 0.587 & $\mathrm{O}$ & \\
\hline E-8 & $45-65$ & 30 & NCR & ND & ND & $\mathrm{X}$ & \\
\hline E-8 & $67-87$ & 11 & NCR & ND & ND & $\mathrm{O} ?$ & \\
\hline E-9 & $28-48$ & 38 & 3 & 0.77 & $0.396^{\mathrm{b}}$ & $\mathrm{O}^{\mathrm{b}}$ & $\begin{array}{l}\text { Reported specific capacity calculated for dd in middle zone (which was } 3.92 \mathrm{ft} \text { ) inter- } \\
\text { connection? }\end{array}$ \\
\hline E-9 & $50-70$ & 29 & 2.1 & 0.077 & $0.087^{b}$ & $\mathrm{X}^{\mathrm{b}}$ & $\begin{array}{l}3.14 \mathrm{ft} d \mathrm{~d} \text { observed above pumped zone; reported specific capacity too high for } 50-70 ? \\
\text { Interconnection }\end{array}$ \\
\hline E-9 & $78-98$ & 14 & NCR & ND & ND & $X$ & $75-95$ \\
\hline
\end{tabular}


Table 2.1. Specific capacities for intervals isolated by packers in selected wells, listed by well and by depth of interval tested at the Valmont TCE Superfund Site, Luzerne County, Pennsylvania. Specific capacity values from, or revised as noted using field notes, from Tetra Tech NUS, Inc. (2016).—Continued

[ft bls, feet below land surface; (gal/min)/ft, gallons per minute per foot drawdown; NCR, no constant rate for pumping; ND, not determined for low-producing zone; WL, water level; LSD, land-surface datum; dd, drawdown; ?, uncertain value]

\begin{tabular}{|c|c|c|c|c|c|c|c|}
\hline Well & $\begin{array}{c}\text { Depth range } \\
\text { for isolated } \\
\text { interval, } \\
\text { in ft bls }\end{array}$ & $\begin{array}{l}\text { Test duration, } \\
\text { in minutes }\end{array}$ & $\begin{array}{c}\text { Average } \\
\text { pumping rate, } \\
\text { in gal/min }\end{array}$ & $\begin{array}{c}\text { Reported } \\
\text { specific } \\
\text { capacity, } \\
\text { in }(\text { gal } / \text { min)/ft }\end{array}$ & $\begin{array}{c}\text { Revised } \\
\text { specific } \\
\text { capacity, } \\
\text { in }(\mathrm{gal} / \mathrm{min}) / \mathrm{ft}\end{array}$ & $\begin{array}{c}\text { Span } \\
\text { shale } \\
\text { contact }^{a}\end{array}$ & Review notes for reported or revised specific capacity vales \\
\hline E-10 & $18-38$ & 16 & NCR & ND & ND & $\mathrm{O}$ & \\
\hline E-10 & $38-58$ & 5 & NCR & ND & ND & $\mathrm{O}$ & \\
\hline E-10 & $59-79$ & 8 & NCR & ND & ND & $\mathrm{X}$ & \\
\hline E-11 & $19-39$ & 37 & 0.8 & 0.063 & 0.0630 & $\mathrm{X}$ & \\
\hline E-11 & $45-65$ & 70 & 0.4 & 0.016 & 0.0160 & $\mathrm{X}$ & Interconnect with lower zone? \\
\hline E-11 & $65-85$ & 5 & NCR & ND & ND & $\mathrm{X}$ & \\
\hline E-11 & $73.5-98^{\mathrm{b}}$ & 7 & NCR & ND & ND & $\mathrm{X}$ & Field notes indicate bottom of upper packer at $73.5 \mathrm{ft}$ \\
\hline E-12 & $21-41$ & 62 & 3.1 & 0.187 & 0.1870 & $\mathrm{X}$ & \\
\hline E-12 & $60-80$ & 6 & NCR & ND & ND & $\mathrm{X}$ & \\
\hline E-12 & $80-96$ & 9 & NCR & ND & ND & $\mathrm{X}$ & \\
\hline E-13 & 19-39 & 44 & 3 & 0.86 & 0.8600 & $X$ & $\begin{array}{l}3.68 \mathrm{ft} \text { dd observed below pumped zone; reported specific capacity too high for } \\
19-39 \text { ? Interconnection }\end{array}$ \\
\hline E-13 & $42-62$ & 4 & NCR & ND & ND & $X$ & \\
\hline E-13 & $62-76$ & 31 & 2.4 & 0.11 & 0.1100 & $\mathrm{X}$ & \\
\hline E-14 & $20-40$ & 124 & 1.2 & 0.054 & 0.0540 & $\mathrm{O}$ & \\
\hline E-14 & $42-62$ & 41 & 0.5 & 0.017 & 0.0170 & $X$ & \\
\hline E-14 & $62-82$ & 10 & 2 & 0.039 & 0.0390 & X & \\
\hline E-10 & $18-38$ & 16 & NCR & ND & ND & $\mathrm{O}$ & \\
\hline E-1 & 19-39 & 153 & 1.1 & 0.107 & 0.1070 & $X$ & \\
\hline E-3 & 19-39 & 71 & 2.4 & 1.71 & $0.1959^{\mathrm{b}}$ & $\mathrm{X}^{\mathrm{b}}$ & Reported specific capacity calculated for dd in middle zone \\
\hline E-6 & $19-39$ & 50 & 3 & 1.54 & $0.3735^{\mathrm{b}}$ & $\mathrm{O}^{\mathrm{b}}$ & Reported specific capacity calculated for dd in middle zone (which was $1.95 \mathrm{ft}$ ) \\
\hline E-7 & $19-39$ & 86 & 1.6 & 0.136 & 0.1360 & $\mathrm{X}$ & \\
\hline E-8 & $19-39$ & 94 & 2 & 0.587 & 0.5870 & $\mathrm{O}$ & \\
\hline E-11 & $19-39$ & 37 & 0.8 & 0.063 & 0.0630 & $X$ & \\
\hline E-13 & 19-39 & 44 & 3 & 0.86 & 0.8600 & X & $\begin{array}{l}3.68 \mathrm{ft} \text { dd observed below pumped zone; reported specific capacity too high for } \\
19-39 \text { ? Interconnection }\end{array}$ \\
\hline E-5 & $20-40$ & 64 & 3.5 & 0.622 & 0.6220 & X & $\begin{array}{l}1.61 \mathrm{ft} \text { dd observed below pumped zone; reported specific capacity too high for } \\
20-40 \text { ? Interconnection }\end{array}$ \\
\hline E-14 & $20-40$ & 124 & 1.2 & 0.054 & 0.0540 & $\mathrm{O}$ & \\
\hline
\end{tabular}


Table 2.1. Specific capacities for intervals isolated by packers in selected wells, listed by well and by depth of interval tested at the Valmont TCE Superfund Site, Luzerne County, Pennsylvania. Specific capacity values from, or revised as noted using field notes, from Tetra Tech NUS, Inc. (2016).—Continued dd, drawdown; ?, uncertain value]

\begin{tabular}{|c|c|c|c|c|c|c|c|}
\hline Well & $\begin{array}{l}\text { Depth range } \\
\text { for isolated } \\
\text { interval, } \\
\text { in ft bls }\end{array}$ & $\begin{array}{l}\text { Test duration, } \\
\text { in minutes }\end{array}$ & $\begin{array}{c}\text { Average } \\
\text { pumping rate, } \\
\text { in gal/min }\end{array}$ & $\begin{array}{c}\text { Reported } \\
\text { specific } \\
\text { capacity, } \\
\text { in }(\mathrm{gal} / \mathrm{min}) / \mathrm{ft}\end{array}$ & $\begin{array}{c}\text { Revised } \\
\text { specific } \\
\text { capacity, } \\
\text { in }(\mathrm{gal} / \mathrm{min}) / \mathrm{ft}\end{array}$ & $\begin{array}{c}\text { Span } \\
\text { shale } \\
\text { contact }^{a}\end{array}$ & Review notes for reported or revised specific capacity vales \\
\hline E-12 & $21-41$ & 62 & 3.1 & 0.187 & 0.1870 & $\mathrm{X}$ & \\
\hline E-9 & $28-48$ & 38 & 3 & 0.77 & $0.3960^{\mathrm{b}}$ & $\mathrm{O}^{\mathrm{b}}$ & $\begin{array}{l}\text { Reported specific capacity calculated for dd in middle zone (which was } 3.92 \mathrm{ft} \text { ) inter- } \\
\text { connection? }\end{array}$ \\
\hline E-2 & $30-50$ & 70 & 3 & 0.225 & 0.2250 & $\mathrm{O}$ & \\
\hline E-4 & $30-50$ & 85 & 2.5 & 1.02 & $0.2900^{\mathrm{b}}$ & $\mathrm{X}^{\mathrm{b}}$ & Reported specific capacity calculated for dd in middle zone (which was $1.54 \mathrm{ft}$ ) \\
\hline E-10 & $38-58$ & 5 & NCR & ND & ND & $\mathrm{O}$ & \\
\hline E-13 & $42-62$ & 4 & NCR & ND & ND & $\mathrm{X}$ & \\
\hline E-14 & $42-62$ & 41 & 0.5 & 0.017 & 0.0170 & $\mathrm{X}$ & \\
\hline E-3 & $45-65$ & 91 & 1.3 & 0.117 & 0.1170 & $\mathrm{X}$ & \\
\hline E-5 & $45-65$ & 29 & 6 & 1.097 & 1.0970 & $\mathrm{O}$ & $\begin{array}{l}\text { Large dd (3.84 ft) observed in upper interval, reported specific capacity too high for } \\
45-65 \text { ? Interconnection; spans faults }\end{array}$ \\
\hline E-6 & $45-65$ & 6 & NCR & ND & ND & $\mathrm{X}$ & \\
\hline E-8 & $45-65$ & 30 & NCR & ND & ND & $\mathrm{X}$ & \\
\hline E-11 & $45-65$ & 70 & 0.4 & 0.016 & 0.0160 & $\mathrm{X}$ & Interconnect with lower zone? \\
\hline E-7 & $47-67$ & 206 & 0.65 & 0.313 & $0.0538^{\mathrm{b}}$ & $\mathrm{X}^{\mathrm{b}}$ & From dd and pumping rate on day 2 \\
\hline E-2 & $50-70$ & 98 & 1.25 & 0.067 & 0.0670 & $\mathrm{X}$ & \\
\hline E-9 & $50-70$ & 29 & 2.1 & 0.077 & $0.0870^{\mathrm{b}}$ & $X^{b}$ & $\begin{array}{l}3.14 \mathrm{ft} \text { dd observed above pumped zone; reported specific capacity too high for } 50-70 ? \\
\text { Interconnection }\end{array}$ \\
\hline E-10 & $59-79$ & 8 & NCR & ND & ND & $X$ & \\
\hline E-12 & $60-80$ & 6 & NCR & ND & ND & $X$ & \\
\hline E-13 & $62-76$ & 31 & 2.4 & 0.11 & 0.1100 & $X$ & \\
\hline E-14 & $62-82$ & 10 & 2 & 0.039 & 0.0390 & $X$ & \\
\hline E-1 & $64-84$ & 68 & 0.25 & 0.0062 & 0.0062 & $X$ & Interval not equilibrated before pumping began-pre-pumping WL near LSD \\
\hline E-11 & $65-85$ & 5 & NCR & ND & ND & $\mathrm{X}$ & \\
\hline E-8 & $67-87$ & 11 & NCR & ND & ND & $\mathrm{O} ?$ & \\
\hline E-4 & $70-90$ & 15 & NCR & ND & ND & $\mathrm{X}$ & \\
\hline E-7 & $70-90$ & 8 & NCR & ND & ND & $\mathrm{O}$ & \\
\hline E-11 & $73.5-98^{b}$ & 7 & NCR & ND & ND & $\mathrm{X}$ & Field notes indicates bottom of upper packer at $73.5 \mathrm{ft}$ \\
\hline E-9 & $78-98$ & 14 & NCR & ND & ND & $\mathrm{X}$ & $75-95$ \\
\hline
\end{tabular}


Table 2.1. Specific capacities for intervals isolated by packers in selected wells, listed by well and by depth of interval tested at the Valmont TCE Superfund Site, Luzerne County, Pennsylvania. Specific capacity values from, or revised as noted using field notes, from Tetra Tech NUS, Inc. (2016).—Continued

[ft bls, feet below land surface; (gal/min)/ft, gallons per minute per foot drawdown; NCR, no constant rate for pumping; ND, not determined for low-producing zone; WL, water level; LSD, land-surface datum; dd, drawdown; ?, uncertain value]

\begin{tabular}{|c|c|c|c|c|c|c|c|}
\hline Well & $\begin{array}{c}\text { Depth range } \\
\text { for isolated } \\
\text { interval, } \\
\text { in ft bls }\end{array}$ & $\begin{array}{l}\text { Test duration, } \\
\text { in minutes }\end{array}$ & $\begin{array}{c}\text { Average } \\
\text { pumping rate, } \\
\text { in gal/min }\end{array}$ & $\begin{array}{c}\text { Reported } \\
\text { specific } \\
\text { capacity, } \\
\text { in }(\text { gal } / \text { min)/ft }\end{array}$ & $\begin{array}{c}\text { Revised } \\
\text { specific } \\
\text { capacity, } \\
\text { in }(\text { gal } / \mathrm{min}) / \mathrm{ft}\end{array}$ & $\begin{array}{c}\text { Span } \\
\text { shale } \\
\text { contacta }^{a}\end{array}$ & Review notes for reported or revised specific capacity vales \\
\hline E-12 & $80-96$ & 9 & NCR & ND & ND & $\mathrm{X}$ & \\
\hline E-4 & $95-115$ & 16 & NCR & ND & ND & $\mathrm{O}$ & \\
\hline E-6 & $95-115$ & 14 & NCR & ND & ND & $\mathrm{O}$ & \\
\hline E-1 & 99-119 & 53 & 0.22 & 0.0024 & $0.0057^{\mathrm{b}}$ & $\mathrm{O}^{\mathrm{b}}$ & Interval not equilibrated before pumping began-pre-pumping WL above LSD \\
\hline E-2 & $100-120$ & 53 & 0.22 & 0.0024 & 0.0024 & $\mathrm{X}$ & Interval not equilibrated before pumping began-pre-pumping WL above LSD \\
\hline
\end{tabular}

aScreen interval spans contact between shale and sandstone/conglomerate if value $=\mathrm{X}$ or does not span contact if value $=\mathrm{O}$.

${ }^{b}$ Values revised following U.S. Geological Survey review of field notes. 
Table 2.2. Land-surface altitude, measuring-point altitude, and March 4, 2020, water levels for wells at and near the Valmont TCE Superfund Site, Luzerne County, Pennsylvania. March 2020 water-level data and measuring point altitudes from Tetra Tech NUS, Inc. (2020). Land-surface elevations from surveys, except for values noted otherwise, estimated from light detection and ranging (lidar) digital elevation data. Land-surface elevations determined by survey at well heads are reported in Tetra Tech NUS, Inc. (2004b, 2010, 2011).

[EPA, U.S. Environmental Protection Agency; NAVD 88, North American Vertical Datum of 1988; ft, feet; MP, measuring point; DTW, depth to water; WL, water level; LSA, land-surface altitude; --, no data]

\begin{tabular}{|c|c|c|c|c|c|c|}
\hline \multirow[b]{2}{*}{$\begin{array}{l}\text { EPA local } \\
\text { well } \\
\text { name }\end{array}$} & \multirow{2}{*}{$\begin{array}{c}\text { Land surface } \\
\text { altitude, } \\
\text { in ft above } \\
\text { NAVD } 88\end{array}$} & \multicolumn{5}{|c|}{ March 4, 2020, water levels } \\
\hline & & $\begin{array}{c}\text { MP altitude, } \\
\text { in ft above } \\
\text { NAVD } 88\end{array}$ & $\begin{array}{c}\text { DTW, } \\
\text { in ft below } \\
\text { MP }\end{array}$ & $\begin{array}{c}\text { WL altitude, } \\
\text { in ft above } \\
\text { NAVD } 88\end{array}$ & $\begin{array}{c}\text { MP, } \\
\text { in } \mathrm{ft} \text { above } \\
\text { LSA }\end{array}$ & $\begin{array}{c}\text { DTW, } \\
\text { in } \mathrm{ft} \text { below } \\
\text { LSA }\end{array}$ \\
\hline E-1S & $1,538.20^{\mathrm{a}}$ & $1,539.20$ & 14.08 & $1,525.12$ & 1.00 & 13.08 \\
\hline E-1I & $1,538.20^{\mathrm{a}}$ & $1,539.25$ & 19.69 & $1,519.56$ & 1.05 & 18.64 \\
\hline E-2S & $1,538.40^{\mathrm{a}}$ & $1,540.33$ & 5.70 & $1,534.63$ & 1.93 & 3.77 \\
\hline E-2I & $1,538.40^{\mathrm{a}}$ & $1,540.09$ & 6.90 & $1,533.19$ & 1.69 & 5.21 \\
\hline E-3S & $1,542.72^{\mathrm{a}}$ & $1,542.38$ & 15.73 & $1,526.65$ & -0.34 & 16.07 \\
\hline E-3I & $1,542.72^{\mathrm{a}}$ & $1,542.15$ & 17.62 & $1,524.53$ & -0.57 & 18.19 \\
\hline E-4S & $1,541.98^{\mathrm{a}}$ & $1,541.48$ & 11.85 & $1,529.63$ & -0.50 & 12.35 \\
\hline E-5 & $1,542.51^{\mathrm{a}}$ & $1,542.24$ & 8.53 & $1,533.71$ & -0.27 & 8.80 \\
\hline E-6S & $1,543.18^{\mathrm{a}}$ & $1,542.72$ & 10.09 & $1,532.63$ & -0.46 & 10.55 \\
\hline E-7S & $1,537.98^{\mathrm{a}}$ & $1,537.69$ & 9.35 & $1,528.34$ & -0.29 & 9.64 \\
\hline E-7I & $1,537.98^{\mathrm{a}}$ & $1,537.43$ & 12.65 & $1,524.78$ & -0.55 & 13.20 \\
\hline E-8S & $1,542.79^{a}$ & $1,544.50$ & 8.64 & $1,535.86$ & 1.71 & 6.93 \\
\hline E-9S & $1,543.30^{\mathrm{a}}$ & $1,542.98$ & 9.24 & $1,533.74$ & -0.32 & 9.56 \\
\hline E-9I & $1,543.30^{\mathrm{a}}$ & $1,542.74$ & 9.13 & $1,533.61$ & -0.56 & 9.69 \\
\hline E-10S & $1,542.80^{\mathrm{b}}$ & $1,542.80$ & 8.77 & $1,534.03$ & 0.00 & 8.77 \\
\hline E-11S & $1,542.75^{b}$ & $1,542.74$ & 8.66 & $1,534.08$ & -0.01 & 8.67 \\
\hline E-11I & $1,542.75^{b}$ & $1,542.75$ & 15.38 & $1,527.37$ & 0.00 & 15.38 \\
\hline E-12S & $1,542.92^{b}$ & $1,542.75$ & 8.62 & $1,534.13$ & -0.17 & 8.79 \\
\hline E-13S & $1,542.95^{b}$ & $1,542.93$ & 8.83 & $1,534.10$ & -0.02 & 8.85 \\
\hline E-13I & $1,542.95^{\mathrm{b}}$ & $1,542.94$ & 15.65 & $1,527.29$ & -0.01 & 15.66 \\
\hline E-14S & $1,540.25^{b}$ & $1,539.39$ & 4.78 & $1,534.61$ & -0.86 & 5.64 \\
\hline E-14I & $1,540.25^{b}$ & $1,539.37$ & 8.08 & $1,531.29$ & -0.88 & 8.96 \\
\hline MW-1A & $1,547.14^{\mathrm{a}}$ & $1,548.58$ & 17.57 & $1,531.01$ & 1.44 & 16.13 \\
\hline MW-1B & $1,547.44^{\mathrm{a}}$ & $1,549.22$ & 27.11 & $1,522.11$ & 1.78 & 25.33 \\
\hline MW-1C & $1,547.30^{\mathrm{a}}$ & $1,549.01$ & 27.16 & $1,521.85$ & 1.71 & 25.45 \\
\hline MW-2S & $1,535.43$ & $1,535.43$ & 5.88 & $1,529.55$ & 0.00 & 5.88 \\
\hline MW-2I & $1,535.96^{\mathrm{a}}$ & $1,535.59$ & 6.33 & $1,529.26$ & -0.37 & 6.70 \\
\hline MW-3 & $1,535.73^{\mathrm{a}}$ & -- & -- & -- & -- & -- \\
\hline MW-6S & $1,534.70^{\mathrm{a}}$ & $1,534.28$ & 12.43 & $1,521.85$ & -0.42 & 12.85 \\
\hline MW-6I & $1,534.70^{\mathrm{a}}$ & $1,534.28$ & 20.41 & $1,513.87$ & -0.42 & 20.83 \\
\hline MW-7S & $1,525.25^{\mathrm{a}}$ & $1,524.82$ & 15.35 & $1,509.47$ & -0.43 & 15.78 \\
\hline MW-7I & $1,525.25^{\mathrm{a}}$ & $1,524.82$ & 20.65 & $1,504.17$ & -0.43 & 21.08 \\
\hline MW-8S & $1,514.44^{\mathrm{a}}$ & $1,514.15$ & 16.73 & $1,497.42$ & -0.29 & 17.02 \\
\hline MW-8D & $1,514.44^{\mathrm{a}}$ & $1,514.15$ & 16.00 & $1,498.15$ & -0.29 & 16.29 \\
\hline MW-9S & $1,507.75^{\mathrm{a}}$ & -- & -- & -- & -- & -- \\
\hline
\end{tabular}


Table 2.2. Land-surface altitude, measuring-point altitude, and March 4, 2020, water levels for wells at and near the Valmont TCE Superfund Site, Luzerne County, Pennsylvania. March 2020 water-level data and measuring point altitudes from Tetra Tech NUS, Inc. (2020). Land-surface elevations from surveys, except for values noted otherwise, estimated from light detection and ranging (lidar) digital elevation data. Land-surface elevations determined by survey at well heads are reported in Tetra Tech NUS, Inc. (2004b, 2010, 2011).-Continued

[EPA, U.S. Environmental Protection Agency; NAVD 88, North American Vertical Datum of 1988; ft, feet; MP, measuring point; DTW, depth to water; WL, water level; LSA, land-surface altitude; --, no data]

\begin{tabular}{|c|c|c|c|c|c|c|}
\hline \multirow[b]{2}{*}{$\begin{array}{c}\text { EPA local } \\
\text { well } \\
\text { name } \\
\end{array}$} & \multirow{2}{*}{$\begin{array}{l}\text { Land surface } \\
\text { altitude, } \\
\text { in ft above } \\
\text { NAVD } 88\end{array}$} & \multicolumn{5}{|c|}{ March 4, 2020, water levels } \\
\hline & & $\begin{array}{l}\text { MP altitude, } \\
\text { in ft above } \\
\text { NAVD } 88\end{array}$ & $\begin{array}{c}\text { DTW, } \\
\text { in ft below } \\
\text { MP }\end{array}$ & $\begin{array}{l}\text { WL altitude, } \\
\text { in ft above } \\
\text { NAVD } 88\end{array}$ & $\begin{array}{c}\text { MP, } \\
\text { in } \mathrm{ft} \text { above } \\
\text { LSA }\end{array}$ & $\begin{array}{c}\text { DTW, } \\
\text { in ft below } \\
\text { LSA }\end{array}$ \\
\hline MW-10D & $1,537.97^{\mathrm{a}}$ & -- & -- & -- & -- & -- \\
\hline MW-10A & $1,537.71^{\mathrm{a}}$ & $1,538.45$ & 13.29 & $1,525.16$ & 0.74 & 12.55 \\
\hline MW-10B & $1,537.79^{a}$ & $1,539.21$ & 20.03 & $1,519.18$ & 1.42 & 18.61 \\
\hline MW-10C & $1,538.33^{\mathrm{a}}$ & $1,540.05$ & 21.78 & $1,518.27$ & 1.72 & 20.06 \\
\hline MW-11S & $1,539.07^{\mathrm{a}}$ & $1,540.48$ & 6.75 & $1,533.73$ & 1.41 & 5.34 \\
\hline MW-11D & $1,539.03^{\mathrm{a}}$ & $1,540.58$ & 9.75 & $1,530.83$ & 1.55 & 8.20 \\
\hline MW-12S & $1,542.92^{\mathrm{a}}$ & $1,542.38$ & 18.26 & $1,524.12$ & -0.54 & 18.80 \\
\hline MW-12I & $1,542.92^{\mathrm{a}}$ & $1,542.39$ & 16.13 & $1,526.26$ & -0.53 & 16.66 \\
\hline MW-13S & $1,541.10^{\mathrm{a}}$ & $1,540.85$ & 6.94 & $1,533.91$ & -0.25 & 7.19 \\
\hline MW-13I & $1,540.63^{\mathrm{a}}$ & $1,540.20$ & 15.02 & $1,525.18$ & -0.43 & 15.45 \\
\hline MW-13D & $1,540.63^{\mathrm{a}}$ & $1,540.25$ & 18.55 & $1,521.70$ & -0.38 & 18.93 \\
\hline MW-14S & $1,542.68^{\mathrm{a}}$ & $1,544.49$ & 9.55 & $1,534.94$ & 1.81 & 7.74 \\
\hline MW-14I & $1,542.60^{\mathrm{a}}$ & $1,544.34$ & 12.14 & $1,532.20$ & 1.74 & 10.40 \\
\hline MW-14D & $1,542.60^{\mathrm{a}}$ & $1,544.34$ & 13.87 & $1,530.47$ & 1.74 & 12.13 \\
\hline MW-15S & $1,537.97^{\mathrm{a}}$ & $1,537.39$ & 7.18 & $1,530.21$ & -0.58 & 7.76 \\
\hline MW-15D & $1,537.97^{\mathrm{a}}$ & $1,537.38$ & 15.65 & $1,521.73$ & -0.59 & 16.24 \\
\hline MW-16S & $1,539.44^{\mathrm{a}}$ & $1,541.00$ & 18.73 & $1,522.27$ & 1.56 & 17.17 \\
\hline MW-16I & $1,539.56^{\mathrm{a}}$ & $1,541.30$ & 21.12 & $1,520.18$ & 1.74 & 19.38 \\
\hline MW-16D & $1,539.56^{\mathrm{a}}$ & $1,541.30$ & 21.70 & $1,519.60$ & 1.74 & 19.96 \\
\hline MW-17S & $1,522.09^{a}$ & $1,522.00$ & 12.48 & $1,509.52$ & -0.09 & 12.57 \\
\hline MW-17I & $1,522.00^{\mathrm{a}}$ & $1,522.00$ & 13.17 & $1,508.83$ & 0.00 & 13.17 \\
\hline MW-18S & $1,543.19^{a}$ & $1,542.80$ & 16.04 & $1,526.76$ & -0.39 & 16.43 \\
\hline MW-19S & $1,514.46^{\mathrm{a}}$ & -- & -- & -- & -- & -- \\
\hline MW-19I & $1,513.99^{a}$ & $1,515.47$ & 39.69 & $1,475.78$ & 1.48 & 38.21 \\
\hline MW-19D & $1,513.99^{a}$ & $1,515.47$ & 53.91 & $1,461.56$ & 1.48 & 52.43 \\
\hline MW-20S & $1,535.79^{a}$ & $1,537.73$ & 24.87 & $1,512.86$ & 1.94 & 22.93 \\
\hline MW-20D & $1,536.34^{\mathrm{a}}$ & $1,538.16$ & 33.82 & $1,504.34$ & 1.82 & 32.00 \\
\hline MW-21S & $1,538.42^{\mathrm{a}}$ & $1,539.68$ & 10.96 & $1,528.72$ & 1.26 & 9.70 \\
\hline MW-21I & $1,538.47^{a}$ & $1,539.95$ & 11.09 & $1,528.86$ & 1.48 & 9.61 \\
\hline MW-21D & $1,538.47^{\mathrm{a}}$ & $1,539.95$ & 14.37 & $1,525.58$ & 1.48 & 12.89 \\
\hline MW-22D & $1,542.86^{\mathrm{a}}$ & $1,542.19$ & 68.19 & $1,474.00$ & -0.67 & 68.86 \\
\hline MW-23S & $1,533.64^{\mathrm{a}}$ & $1,533.44$ & 16.79 & $1,516.65$ & -0.20 & 16.99 \\
\hline MW-23I & $1,533.64^{\mathrm{a}}$ & $1,533.28$ & 19.46 & $1,513.82$ & -0.36 & 19.82 \\
\hline MW-24S & $1,526.68^{\mathrm{a}}$ & -- & -- & -- & -- & -- \\
\hline MW-24I & $1,526.68^{a}$ & -- & -- & -- & -- & -- \\
\hline
\end{tabular}


Table 2.2. Land-surface altitude, measuring-point altitude, and March 4, 2020, water levels for wells at and near the Valmont TCE Superfund Site, Luzerne County, Pennsylvania. March 2020 water-level data and measuring point altitudes from Tetra Tech NUS, Inc. (2020). Land-surface elevations from surveys, except for values noted otherwise, estimated from light detection and ranging (lidar) digital elevation data. Land-surface elevations determined by survey at well heads are reported in Tetra Tech NUS, Inc. (2004b, 2010, 2011).-Continued

[EPA, U.S. Environmental Protection Agency; NAVD 88, North American Vertical Datum of 1988; ft, feet; MP, measuring point; DTW, depth to water; WL, water level; LSA, land-surface altitude; --, no data]

\begin{tabular}{|c|c|c|c|c|c|c|}
\hline \multirow[b]{2}{*}{$\begin{array}{c}\text { EPA local } \\
\text { well } \\
\text { name } \\
\end{array}$} & \multirow{2}{*}{$\begin{array}{l}\text { Land surface } \\
\text { altitude, } \\
\text { in ft above } \\
\text { NAVD } 88\end{array}$} & \multicolumn{5}{|c|}{ March 4, 2020, water levels } \\
\hline & & $\begin{array}{l}\text { MP altitude, } \\
\text { in ft above } \\
\text { NAVD } 88\end{array}$ & $\begin{array}{c}\text { DTW, } \\
\text { in ft below } \\
\text { MP }\end{array}$ & $\begin{array}{l}\text { WL altitude, } \\
\text { in ft above } \\
\text { NAVD } 88\end{array}$ & $\begin{array}{c}\text { MP, } \\
\text { in } \mathrm{ft} \text { above } \\
\text { LSA }\end{array}$ & $\begin{array}{c}\text { DTW, } \\
\text { in ft below } \\
\text { LSA }\end{array}$ \\
\hline MW-25S & $1,537.90^{\mathrm{a}}$ & $1,537.22$ & 8.05 & $1,529.17$ & -0.68 & 8.73 \\
\hline MW-25I & $1,537.90^{\mathrm{a}}$ & $1,537.44$ & 14.80 & $1,522.64$ & -0.46 & 15.26 \\
\hline MW-26S & $1,536.48^{\mathrm{a}}$ & $1,536.00$ & 4.11 & $1,531.89$ & -0.48 & 4.59 \\
\hline MW-26I & $1,536.48^{\mathrm{a}}$ & $1,535.99$ & 11.34 & $1,524.65$ & -0.49 & 11.83 \\
\hline MW-27 & $1,494.00^{b}$ & -- & -- & -- & -- & -- \\
\hline MW-28S & $1,538.80^{\mathrm{b}}$ & $1,538.38$ & 11.69 & $1,526.69$ & -0.42 & 12.11 \\
\hline MW-28I & $1,539.00$ & $1,538.58$ & 13.69 & $1,524.89$ & -0.42 & 14.11 \\
\hline MW-28D & $1,538.80^{\mathrm{a}}$ & -- & -- & -- & -- & -- \\
\hline MW-29 & $1,518.86^{\mathrm{a}}$ & -- & -- & -- & -- & -- \\
\hline MW-31S & $1,542.83^{b}$ & $1,542.56$ & 8.62 & $1,533.94$ & -0.27 & 8.89 \\
\hline MW-31I & $1,542.83^{b}$ & $1,542.83$ & 8.97 & $1,533.86$ & 0.00 & 8.97 \\
\hline MW-32S & $1,542.93^{b}$ & $1,542.93$ & 9.03 & $1,533.90$ & 0.00 & 9.03 \\
\hline MW-33S & $1,542.94^{b}$ & $1,542.94$ & 8.73 & $1,534.21$ & 0.00 & 8.73 \\
\hline MW-34S & $1,542.84^{b}$ & $1,542.94$ & 8.65 & $1,534.29$ & 0.10 & 8.55 \\
\hline MW-35S & $1,543.08^{b}$ & $1,543.08$ & 8.68 & $1,534.40$ & 0.00 & 8.68 \\
\hline GW-6 & $1,517.4^{b}$ & -- & -- & -- & -- & -- \\
\hline GW-24 & $1,522.2^{b}$ & -- & -- & -- & -- & -- \\
\hline GW-23 & $1,526.8^{b}$ & -- & -- & -- & -- & -- \\
\hline RW-1 & $1,507.37^{\mathrm{a}}$ & -- & -- & -- & -- & -- \\
\hline $\mathrm{K}-1$ & $1,493.68^{a}$ & -- & -- & -- & -- & -- \\
\hline OW-9 & $1,536.06^{\mathrm{a}}$ & -- & -- & -- & -- & -- \\
\hline OW-12 & $1,535.98^{\mathrm{a}}$ & -- & -- & -- & -- & -- \\
\hline OW-14 & $1,533.49^{\mathrm{a}}$ & -- & -- & -- & -- & -- \\
\hline OW-15 & $1,531.81^{\mathrm{a}}$ & -- & -- & -- & -- & -- \\
\hline OW-20 & $1,539.93^{\mathrm{a}}$ & -- & -- & -- & -- & -- \\
\hline DL-01 & $1,469.1^{\mathrm{b}}$ & -- & -- & -- & -- & -- \\
\hline DL-02 & $1,465.5^{\mathrm{b}}$ & -- & -- & -- & -- & -- \\
\hline
\end{tabular}

aValues indicate land-surface elevations determined from survey.

${ }^{b}$ Values were estimated from lidar digital elevation data. 
For additional information, contact::

Director, Pennsylvania Water Science Center

U.S. Geological Survey

215 Limekiln Road

New Cumberland, PA 17070

or visit our website at: https://www.usgs.gov/centers/pa-water

Publishing support provided by the

West Trenton Publishing Service Center 
